Prepared in cooperation with the California State Water Resources Control Board and the U.S. Geological Survey National Water-Quality Assessment Program

A product of the California Groundwater Ambient Monitoring and Assessment (GAMA) Program

\title{
Status and Understanding of Groundwater Quality in the Northern Coast Ranges Study Unit, 2009: California GAMA Priority Basin Project
}

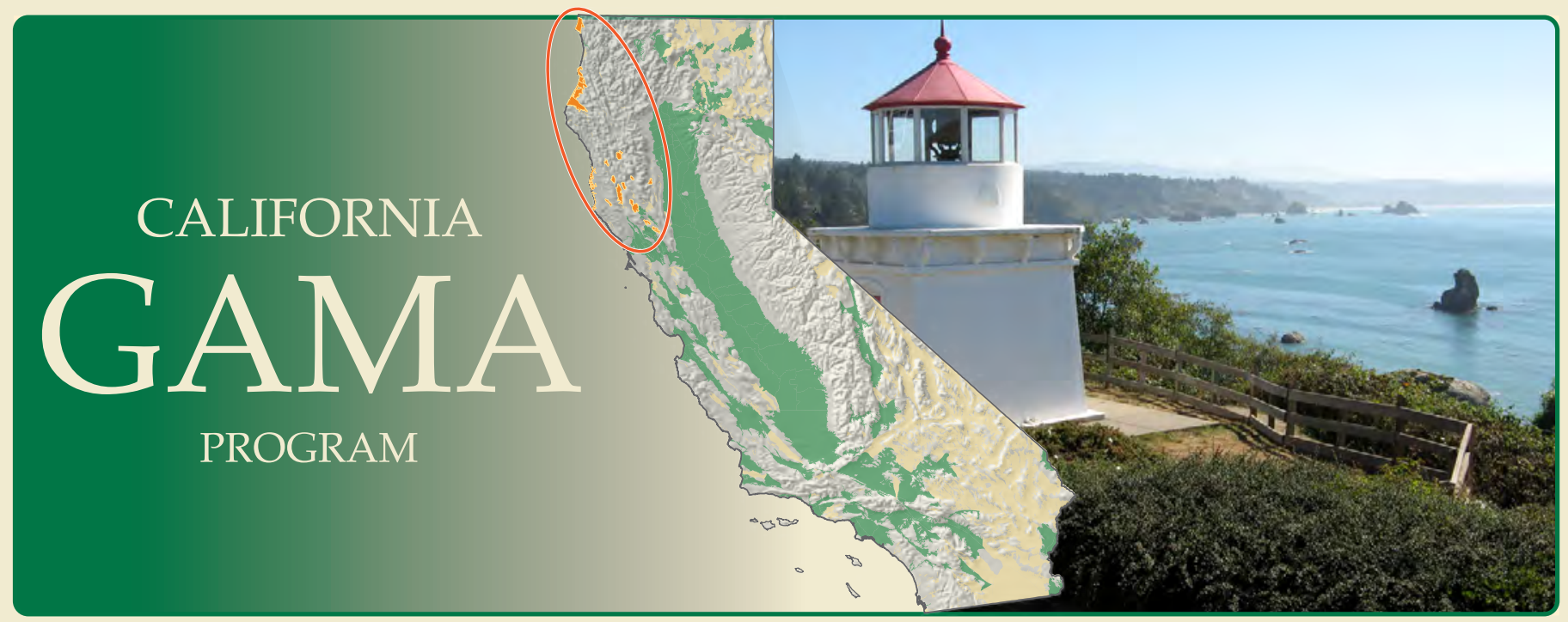

Scientific Investigations Report 2014-5215 
Front Cover Map: Groundwater basins categorized by sampling priority. Location of groundwater basin boundaries from California Department of Water Resources (CDWR, 2003).

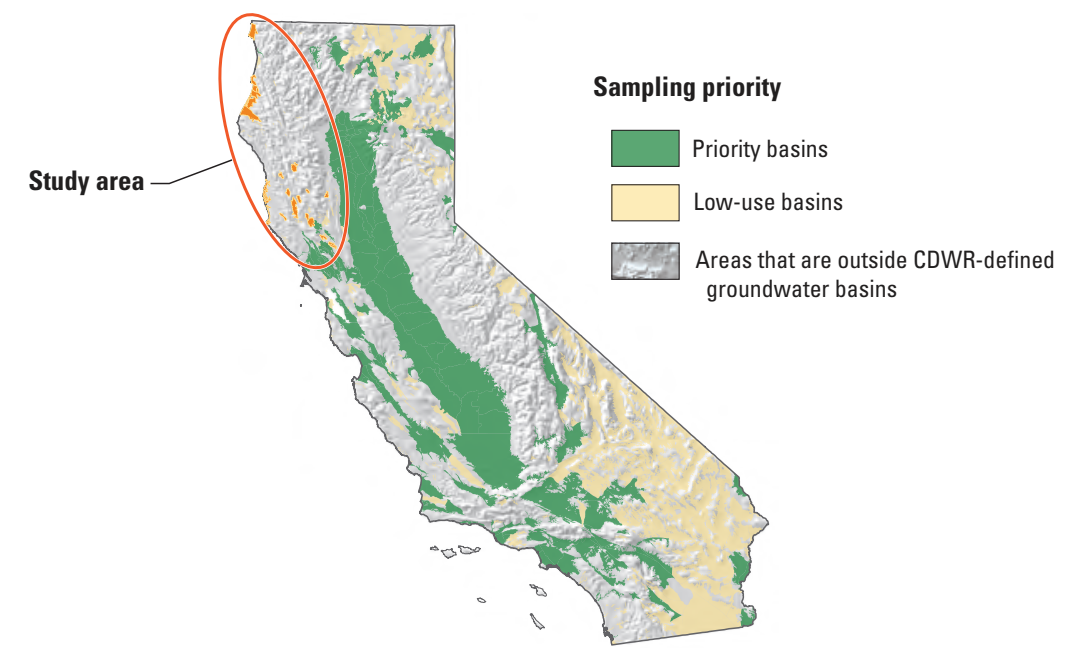

Cover photographs:

Front cover: Trinidad Head Memorial, Trinidad, California. (Photograph taken by George Bennett V, U.S. Geological Survey.)

Back cover: Eel River from California Highway 162, near Covelo, California. (Photograph taken by Barbara Dawson, U.S. Geological Survey.) 


\section{Status and Understanding of Groundwater Quality in the Northern Coast Ranges Study Unit, 2009: California GAMA Priority Basin Project}

By Timothy M. Mathany and Kenneth Belitz

A product of the California Groundwater Ambient Monitoring and Assessment (GAMA) Program

Prepared in cooperation with the California State Water Resources Control Board and the U.S. Geological Survey National Water-Quality Assessment Program

Scientific Investigations Report 2014-5215 


\title{
U.S. Department of the Interior SALLY JEWELL, Secretary
}

\section{U.S. Geological Survey Suzette M. Kimball, Acting Director}

\author{
U.S. Geological Survey, Reston, Virginia: 2015
}

For more information on the USGS - the Federal source for science about the Earth, its natural and living resources, natural hazards, and the environment, visit http://www.usgs.gov or call 1-888-ASK-USGS.

For an overview of USGS information products, including maps, imagery, and publications, visit http://www.usgs.gov/pubprod

To order this and other USGS information products, visit http://store.usgs.gov

Any use of trade, firm, or product names is for descriptive purposes only and does not imply endorsement by the U.S. Government.

Although this information product, for the most part, is in the public domain, it also may contain copyrighted materials as noted in the text. Permission to reproduce copyrighted items must be secured from the copyright owner.

Suggested citation:

Mathany, T.M., and Belitz, Kenneth, 2015, Status and understanding of groundwater quality in the Northern Coast Ranges study unit, 2009—California GAMA Priority Basin Project: U.S. Geological Survey Scientific Investigations Report 2014-5215, 86 p., http://dx.doi.org/10.3133/sir20145215.

ISSN 2328-031X (print) ISSN 2328-0328 (online) ISBN 978-1-4113-3904-0 


\section{Contents}

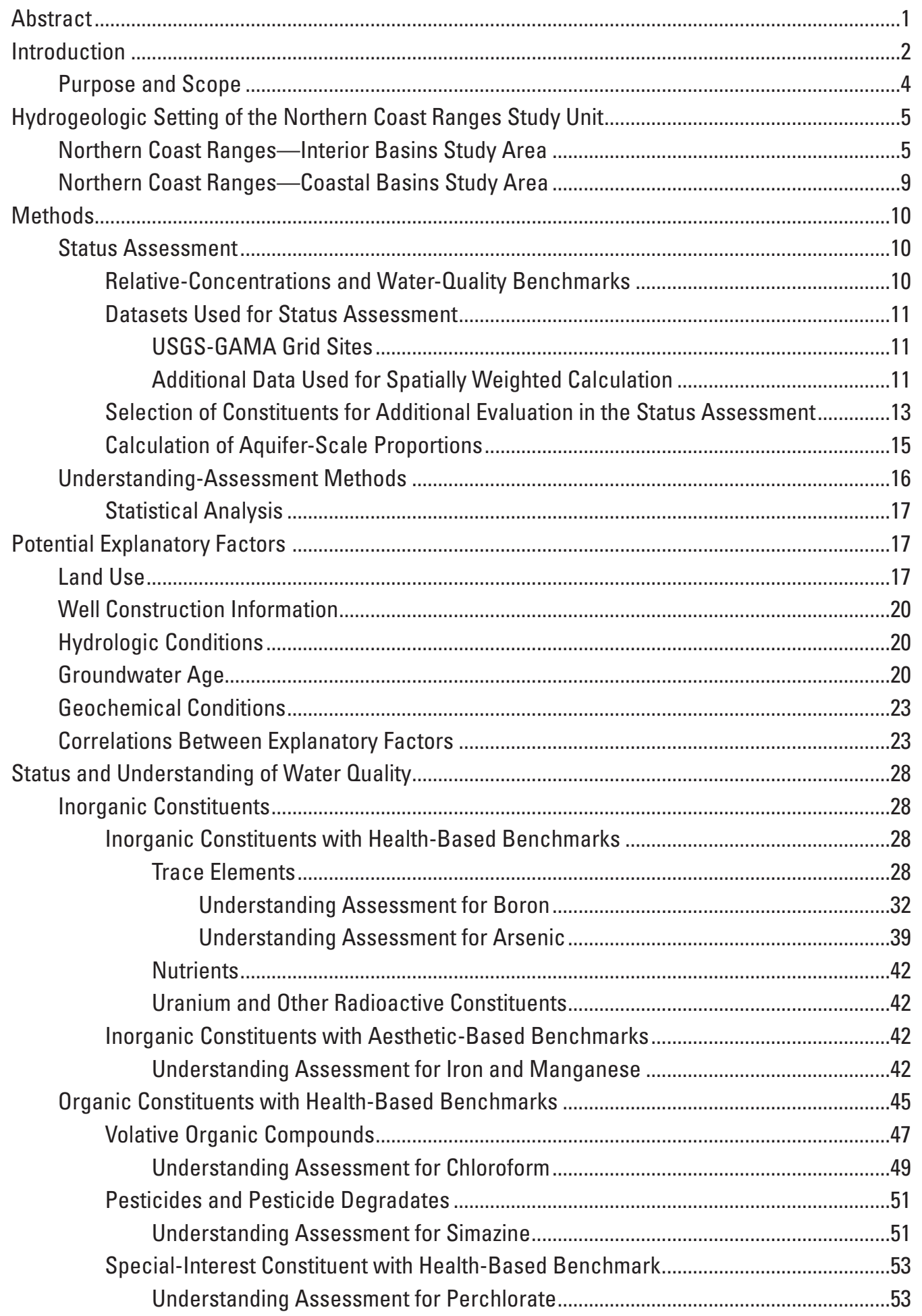




\section{Contents-Continued}

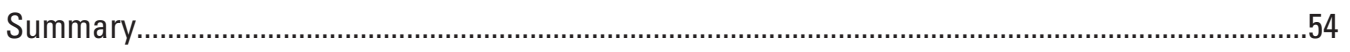

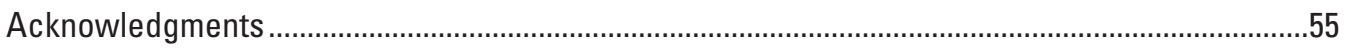

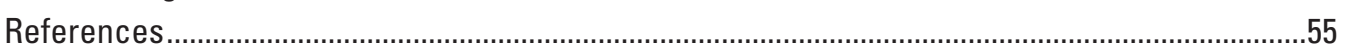

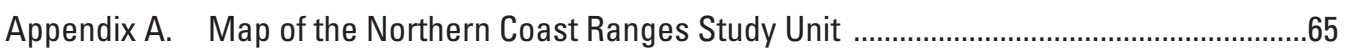

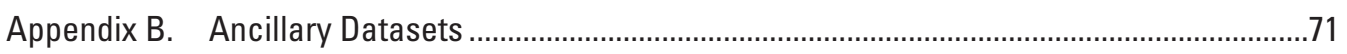

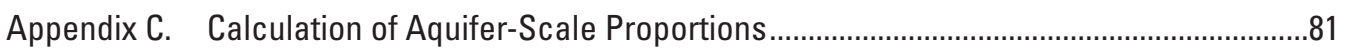

Appendix D. Comparison of CDPH and GAMA Priority Basin Data ...........................................83

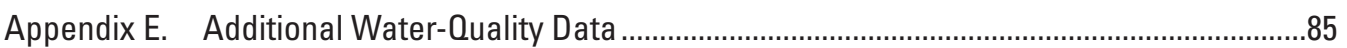

\section{Figures}

1. Map showing location of the Northern Coast Ranges study unit and the California hydrogeologic provinces, California GAMA Priority Basin Project.

2. Map showing location of the Coastal Basins and Interior Basins study areas, major cities and towns, major roads, and hydrologic features in the Northern Coast Ranges study unit, 2009, California GAMA Priority Basin Project.

3. Maps showing geologic formations and locations of the Coastal Basins study area and Interior Basins study area, locations of hot springs and geothermal wells, and approximate boundaries of the Napa and Sonoma Valleys and the Geysers Steam Field, Northern Coast Ranges study unit, 2009, California GAMA Priority Basin Project.

4. Map showing locations of study area grid cells, USGS-GAMA grid sites, and CDPH sites, Northern Coast Ranges study unit, 2009, California GAMA Priority Basin Project.

5. Map showing land use and the location of leaking or formerly leaking underground fuel tanks in the Northern Coast Ranges study unit, 2009, California GAMA Priority Basin Project.

6. Ternary diagram showing percentage of urban, agricultural, and natural land uses for the study unit and study areas and the area surrounding each USGS-GAMA grid site in the Northern Coast Ranges study unit, 2009, California GAMA Priority Basin Project.

7. Boxplots showing construction characteristics for USGS-GAMA grid sites in the Interior Basins study area and Coastal Basins study area, Northern Coast Ranges study unit, 2009, California GAMA Priority Basin Project.

8. Boxplots showing relation of groundwater age classification to well depth and depth to top-of-perforations for wells in the Interior Basins study area, well depth and depth to top-of-perforations for wells in the Coastal Basins study area, and bar chart showing the depth class of all wells in the Northern Coast Ranges study unit, 2009, California GAMA Priority Basin Project.

9. Graphs showing groundwater age classification and well depth in relation to $\mathrm{pH}$ and dissolved oxygen concentrations, Northern Coast Ranges study unit, 2009, California GAMA Priority Basin Project.

10. Graph showing maximum relative-concentration of constituents detected in USGS-GAMA grid sites, by constituent class, Northern Coast Ranges study unit, 2009, California GAMA Priority Basin Project. 


\section{Figures-Continued}

11. Graphs showing relative-concentrations of selected constituents with health-based benchmarks and constituents with aesthetic-based benchmarks in USGS-GAMA grid sites, Northern Coast Ranges study unit, 2009, California GAMA Priority Basin Project.

12. Maps showing relative-concentrations of boron in USGS-GAMA grid sites and geologic features in the Coastal Basins study area and Interior Basins study area, and geologic formations, locations of hot springs and geothermal wells, and approximate boundaries of the Napa and Sonoma Valleys and the Geysers Steam Field, Northern Coast Ranges study unit, 2009, California GAMA Priority Basin Project.

13. Maps showing relative-concentrations of arsenic in USGS-GAMA grid sites, CDPH sites for the period June 1, 2006-June 1, 2009, from the CDPH water-quality database, and geologic features in the Coastal Basins study area and Interior Basins study area and geologic formations, locations of hot springs and geothermal wells, and approximate boundaries of the Napa and Sonoma Valleys and the Geysers Steam Field Northern Coast Ranges study unit, 2009, California GAMA Priority Basin Project.

14. Plots showing boron concentrations relative to field water temperature, field water temperature and distance to nearest hot spring, field water temperature and distance to nearest geothermal well, and redox classification in USGS-GAMA grid sites sampled for the Northern Coast Ranges study unit, 2009, California GAMA Priority Basin Project

15. Plots showing arsenic concentrations relative to groundwater age classification and redox classification in USGS-GAMA grid sites sampled for the Northern Coast Ranges study unit, 2009, California GAMA Priority Basin Project...

16. Maps showing relative-concentrations of iron in USGS-GAMA grid sites and CDPH sites for the period June 1, 2006-June 1, 2009, from the CDPH water-quality database in the Coastal Basins study area and Interior Basins study area, Northern Coast Ranges study unit, 2009, California GAMA Priority Basin Project

17. Maps showing relative-concentrations of manganese in USGS-GAMA grid sites and CDPH sites for the period June 1, 2006-June 1, 2009, from the CDPH water-quality database in the Coastal Basins study area and Interior Basins study area, Northern Coast Ranges study unit, 2009, California GAMA Priority Basin Project.

18. Graph showing maximum relative-concentration of organic and special-interest constituents detected in USGS-GAMA grid sites, Northern Coast Ranges study unit, 2009, California GAMA Priority Basin Project

19. Graphs showing detection frequency and maximum relative-concentration of organic and special-interest constituents detected in USGS-GAMA grid sites, Northern Coast Ranges study unit, 2009, California GAMA Priority Basin Project.

20. Maps showing relative-concentrations of chloroform detected in USGS-GAMA grid sites and CDPH sites for the period June 1, 2006-June 1, 2009, from the CDPH water-quality database, and locations of leaking or formerly leaking underground fuel tanks, Northern Coast Ranges study unit, 2009, California GAMA Priority Basin Project

21. Plots showing trihalomethane chloroform concentrations relative to groundwater age classification and depth to top-of-perforations in USGS-GAMA grid sites sampled for the Northern Coast Ranges study unit, 2009, California GAMA Priority Basin Project. 


\section{Figures-Continued}

22. Map showing relative-concentrations of simazine detected in USGS-GAMA grid sites and CDPH sites for the period June 1, 2006-June 1, 2009, from the CDPH water-quality database, and locations of leaking or formerly leaking underground fuel tanks, Northern Coast Ranges study unit, 2009, California GAMA Priority Basin Project.

23. Plot showing the herbicide simazine concentrations relative to groundwater age classification and depth to top-of-perforations in USGS-GAMA grid sites sampled for the Northern Coast Ranges study unit, 2009, California GAMA Priority Basin Project

24. Maps showing relative-concentrations of perchlorate in USGS-GAMA grid sites and CDPH sites for the period June 1, 2006-June 1, 2009, from the CDPH water-quality database, and land use, Northern Coast Ranges study unit, 2009, California GAMA Priority Basin Project.

25. Plot showing the special-interest constituent perchlorate concentrations relative to geochemical condition and depths to top-of-perforations in USGS-GAMA grid sites sampled for the Northern Coast Ranges study unit, 2009, California GAMA Priority Basin Project.

\section{Tables}

1. Constituent classes and numbers of constituents analyzed for the 58 sites sampled, Northern Coast Ranges study unit, 2009, California GAMA Priority Basin Project .........11

2. Numbers of constituents analyzed and detected in each constituent class with each type of benchmark, Northern Coast Ranges study unit, 2009, California GAMA Priority Basin Project

3. Constituents selected for additional evaluation in the status assessment, Northern Coast Ranges study unit, 2009, California GAMA Priority Basin Project

4. Constituents reported at concentrations greater than benchmarks historically in the California Department of Public Health database, but not during the 3-year time period used in the status assessment, Northern Coast Ranges study unit, California GAMA Priority Basin Project

5. Results of non-parametric analysis of correlations between selected potential explanatory factors, Northern Coast Ranges study unit, 2009, California GAMA Priority Basin Project...

6. Results of Wilcoxon rank-sum tests on USGS-GAMA grid site data used to determine significant differences between constituent values grouped by potential explanatory factors, Northern Coast Ranges study unit, 2009, California GAMA Priority Basin Project.....

7. Aquifer-scale proportions calculated using grid-based and spatially weighted methods for those constituents that met criteria for additional evaluation in the status assessment, Northern Coast Ranges study unit, 2009, California GAMA Priority Basin Project.

8A. Summary of aquifer-scale proportions for inorganic constituent classes, Northern Coast Ranges study unit, 2009, California GAMA Priority Basin Project

8B. Summary of aquifer-scale proportions for organic and special-interest constituent classes, Northern Coast Ranges study unit, 2009, California GAMA Priority Basin Project

9. Results of non-parametric analysis for correlations between selected water-quality constituents and potential explanatory factors, Northern Coast Ranges study unit, 2009, California GAMA Priority Basin Project. 


\section{Conversion Factors, Datums, and Abbreviations and Acronyms Conversion Factors}

\begin{tabular}{|c|c|c|}
\hline Multiply & By & To obtain \\
\hline \multicolumn{3}{|c|}{ Length } \\
\hline inch (in.) & 2.54 & centimeter $(\mathrm{cm})$ \\
\hline foot $(\mathrm{ft})$ & 0.3048 & meter $(\mathrm{m})$ \\
\hline mile (mi) & 1.609 & kilometer $(\mathrm{km})$ \\
\hline \multicolumn{3}{|c|}{ Area } \\
\hline square mile $\left(\mathrm{mi}^{2}\right)$ & 2.590 & square kilometer $\left(\mathrm{km}^{2}\right)$ \\
\hline \multicolumn{3}{|l|}{ SI to Inch/Pound } \\
\hline Multiply & By & To obtain \\
\hline \multicolumn{3}{|c|}{ Length } \\
\hline centimeter $(\mathrm{cm})$ & 0.3937 & inch (in.) \\
\hline meter (m) & 3.281 & foot $(\mathrm{ft})$ \\
\hline kilometer $(\mathrm{km})$ & 0.6214 & mile (mi) \\
\hline \multicolumn{3}{|c|}{ Area } \\
\hline square kilometer $\left(\mathrm{km}^{2}\right)$ & 0.3861 & square mile $\left(\mathrm{mi}^{2}\right)$ \\
\hline
\end{tabular}

Temperature in degrees Celsius $\left({ }^{\circ} \mathrm{C}\right)$ may be converted to degrees Fahrenheit $\left({ }^{\circ} \mathrm{F}\right)$ as follows:

${ }^{\circ} \mathrm{F}=\left(1.8 x^{\circ} \mathrm{C}\right)+32$

Temperature in degrees Fahrenheit $\left({ }^{\circ} \mathrm{F}\right)$ may be converted to degrees Celsius $\left({ }^{\circ} \mathrm{C}\right)$ as follows:

${ }^{\circ} \mathrm{C}=\left({ }^{\circ} \mathrm{F}-32\right) / 1.8$

Concentrations of chemical constituents in water are given either in milligrams per liter $(\mathrm{mg} / \mathrm{L})$, or micrograms per liter ( $\mu \mathrm{g} / \mathrm{L})$. One milligram per liter is equivalent to 1 part per million $(\mathrm{ppm})$; 1 microgram per liter is equivalent to 1 part per billion (ppb).

Concentrations of dissolved noble gases in water are given in standard pressure per gram of water $\left(\mathrm{g}^{-1} \mathrm{H}_{2} \mathrm{O}\right)$.

\section{Datums}

Vertical coordinate information is referenced to the North American Vertical Datum of 1988 (NAVD 88).

Horizontal coordinate information is referenced to the North American Datum of 1983 (NAD 83). Land-surface altitude, as used in this report, refers to distance above the vertical datum and is reported as feet above mean sea level (ft above $\mathrm{msl}$ ).

Depth, as used in this report, refers to distance below the land-surface datum and is reported as feet below land surface (ft bls). 


\section{Selected terms and symbols}

$\begin{array}{ll}= & \text { equal to } \\ > & \text { greater than } \\ \geq & \text { greater than or equal to } \\ < & \text { less than } \\ \leq & \text { less than or equal to }\end{array}$

\section{Abbreviations and Acronyms}

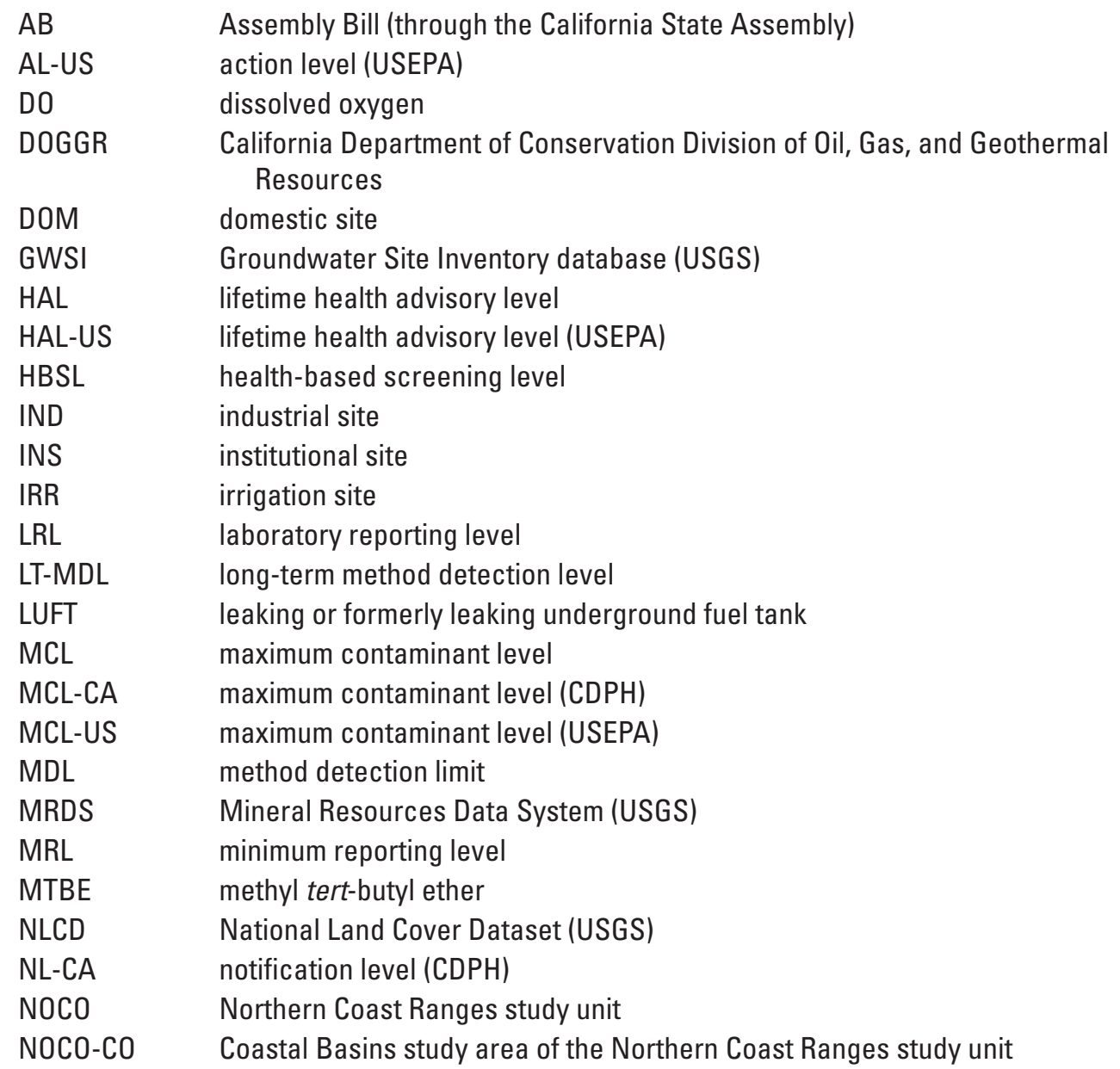




\section{Abbreviations and Acronyms - Continued}

$\begin{array}{ll}\text { NOCO-IN } & \text { Interior Basins study area of the Northern Coast Ranges study unit } \\ \text { ns } & \text { no significant difference } \\ \text { NWIS } & \text { National Water Information System (USGS) } \\ \text { p } & \text { significance level } \\ \text { pmc } & \text { percent modern carbon } \\ \text { RSD5-US } & \text { risk-specific dose at a risk factor of 10-5 (USEPA) } \\ \text { SMCL } & \text { secondary maximum contaminant level } \\ \text { SMCL-CA } & \text { secondary maximum contaminant level (CDPH) } \\ \text { SMCL-US } & \text { secondary maximum contaminant level (USEPA) } \\ \text { TDS } & \text { total dissolved solids } \\ \text { TEAP } & \text { terminal electron acceptor process } \\ \text { THM } & \text { trihalomethane } \\ \text { TT-US } & \text { treatment technique level (USEPA) } \\ \text { TU } & \text { tritium unit } \\ \text { VOC } & \text { volatile organic compound } \\ \text { Z } & \text { test statistic for Wilcoxon test }\end{array}$

\section{Organizations}

CDPH California Department of Public Health (California Department of Health Services prior to July 1, 2007)

CDPR California Department of Pesticide Regulation

CDWR California Department of Water Resources

GAMA Groundwater Ambient Monitoring and Assessment Program (USGS)

LLNL Lawrence Livermore National Laboratory, Livermore, California

NAWQA National Water-Quality Assessment Program (USGS)

SWRCB California State Water Resources Control Board

USEPA U.S. Environmental Protection Agency

USGS U.S. Geological Survey 


\title{
Status and Understanding of Groundwater Quality in the Northern Coast Ranges Study Unit, 2009: California GAMA Priority Basin Project
}

\author{
By Timothy M. Mathany and Kenneth Belitz
}

\section{Abstract}

Groundwater quality in the 633-square-mile (1,639-square-kilometer) Northern Coast Ranges (NOCO) study unit was investigated as part of the Priority Basin Project (PBP) of the Groundwater Ambient Monitoring and Assessment (GAMA) Program and the U.S. Geological Survey (USGS) National Water-Quality Assessment Program. The study unit is composed of two study areas (Interior Basins and Coastal Basins) and is located in northern California in Napa, Sonoma, Lake, Colusa, Mendocino, Glenn, Humboldt, and Del Norte Counties. The GAMA-PBP is being conducted by the California State Water Resources Control Board in collaboration with the USGS and the Lawrence Livermore National Laboratory.

The GAMA NOCO study was designed to provide a spatially unbiased assessment of the quality of untreated (ambient) groundwater in the primary aquifer system within the study unit. The assessment is based on water-quality and ancillary data collected in 2009 by the USGS from 58 sites and on water-quality data from the California Department of Public Health (CDPH) database. The primary aquifer system is defined by the perforation intervals of sites listed in the CDPH water-quality database for the NOCO study unit. Groundwater quality in the primary aquifer system may differ from the quality in the shallow or deep water-bearing zones.

The first component of this study, the status assessment of the current quality of the groundwater resource, was performed by using data from samples analyzed for inorganic constituents (such as trace elements and major and minor ions), organic constituents (volatile organic compounds and pesticides and pesticide degradates), the special-interest constituent perchlorate, and microbial indicators. This status assessment is intended to characterize the quality of groundwater resources in the primary aquifer system of the NOCO study unit, not the quality of treated drinking water delivered to consumers by water purveyors.

Relative-concentrations (sample concentration divided by the health- or aesthetic-based benchmark concentration) were used for evaluating groundwater quality for those constituents that have Federal or California regulatory or nonregulatory benchmarks for drinking-water quality. A relativeconcentration greater than $(>) 1.0$ indicates a concentration greater than a benchmark, and a relative-concentration less than or equal to $(\leq) 1.0$ indicates a concentration less than or equal to a benchmark. Relative-concentrations of organic constituents and perchlorate were classified as "high" (relative-concentration $>1.0)$, "moderate" $(0.1<$ relativeconcentration $\leq 1.0$ ), or "low" (relative-concentration $\leq 0.1$ ). Relative-concentrations of inorganic constituents were classified as "high" (relative-concentration $>1.0$ ), "moderate" $(0.5<$ relative-concentration $\leq 1.0)$, or "low" (relativeconcentration $\leq 0.5$ ).

Aquifer-scale proportion was used as the primary metric in the status assessment for evaluating regional-scale groundwater quality. High aquifer-scale proportion was defined as the percentage of the area of the primary aquifer system with a relative-concentration $>1.0$ for a particular constituent or class of constituents; the percentage is based on an aerial rather than a volumetric basis. Moderate and low aquifer-scale proportions were defined as the percentage of the primary aquifer system with moderate and low relativeconcentrations, respectively. Two statistical approachesgrid-based and spatially weighted - were used to evaluate aquifer-scale proportions for individual constituents and classes of constituents. Grid-based and spatially weighted estimates were comparable in the NOCO study unit (within 90 percent confidence intervals).

Inorganic constituents (one or more) with health-based benchmarks were detected at high relative-concentrations in 10.3 percent and at moderate relative-concentrations in 13.8 percent of the primary aquifer system. The high aquiferscale proportion of inorganic constituents primarily reflected high aquifer-scale proportions of boron (in 8.6 percent of the primary aquifer system), arsenic (in 3.4 percent), and barium (in 1.7 percent). Inorganic constituents with aesthetic-based benchmarks were detected at high relative-concentrations in 39.7 percent and at moderate relative-concentrations in 10.3 percent of the primary aquifer system. The constituents present at high relative-concentrations were iron (25.9 percent) and manganese (39.7 percent). 
Relative-concentrations of organic constituents with health-based benchmarks (one or more) were high in 0.2 percent, moderate in 1.7 percent, and low in 39.7 percent of the primary aquifer system. Organic constituents were not detected in 58.4 percent of the primary aquifer system. Of the 168 organic constituents analyzed, 11 constituents were detected. Two organic constituents had detection frequencies $>10$ percent: the trihalomethane chloroform and the herbicide simazine. For the 10 detected organic constituents that had health-based benchmarks, nearly all detections had low relative-concentrations. The special-interest constituent perchlorate was detected at moderate relative-concentrations in 1.7 percent and at low relative-concentrations in 22.4 percent of the primary aquifer system. Perchlorate was not detected in 75.9 percent of the primary aquifer system.

The second component of this study, the understanding assessment, evaluated relations between constituent concentrations and values of selected potential explanatory factors to identify the factors potentially affecting the concentrations and occurrences of constituents found at high relative-concentrations or, for organic constituents, with detection frequencies $>10$ percent. The potential explanatory factors evaluated were land use (including density of septic tanks and leaking or formerly leaking underground fuel tanks), well construction (well depth and depth to the top of the perforated interval in the well), hydrologic conditions (aridity index, field water temperature, and distance to nearest hot spring and geothermal well), $\mathrm{pH}$, dissolved oxygen concentration, study area, groundwater age distribution, and geochemical conditions.

High and moderate relative-concentrations of boron primarily occurred in the Interior Basins study area and may be attributed to groundwater interacting with hydrothermal systems. High and moderate relative-concentrations of boron were associated with elevated groundwater temperatures, groundwater chemistry characteristics similar to those of geothermal waters, and distance to known geothermal areas. Boron concentrations generally were higher where low dissolved oxygen concentrations or anoxic conditions exist. High and moderate relative-concentrations of arsenic predominantly occur in the Interior Basins study area under reducing conditions. Arsenic concentrations also may be influenced by hydrothermal systems (when present).

Chloroform, simazine, and perchlorate were observed in the Interior Basins and Coastal Basins study areas, predominantly at shallow sites with top-of-perforation depths $\leq 70$ feet below land surface, with modern water (post-1950s), and with oxic groundwater conditions.

\section{Introduction}

To assess the quality of ambient groundwater in aquifers used for drinking-water supply and to establish a baseline groundwater-quality monitoring program, the California State Water Resources Control Board (SWRCB), in collaboration with the U.S. Geological Survey (USGS) and Lawrence
Livermore National Laboratory (LLNL), implemented the Groundwater Ambient Monitoring and Assessment (GAMA) Program (California State Water Resources Control Board, 2011, website at http://www.waterboards.ca.gov/water_issues/ programs/gama/). The statewide GAMA Program was initiated in 2000 in response to Legislative mandates (State of California, 1999, 2001a). The program currently consists of four projects: (1) the GAMA Priority Basin Project (GAMA-PBP), conducted by the USGS (U.S. Geological Survey, 2011, California Water Science Center website at http://ca.water.usgs.gov/gama/); (2) the GAMA Domestic Well Project, conducted by the SWRCB; (3) the GAMA Special Studies, conducted by LLNL; and (4) the GeoTracker GAMA web-based groundwater information system, developed by the SWRCB. On a statewide basis, the GAMA-PBP focused on the primary aquifer system, typically the deep portion of the groundwater resource, and the SWRCB Domestic Well Project generally focused on the shallow aquifer systems.

In response to the Groundwater Quality Monitoring Act of 2001, the GAMA-PBP was initiated in 2003 to assess and monitor the quality of groundwater in California (State of California, 2001b). The USGS, in collaboration with the SWRCB, designed the GAMA-PBP as a means to assess groundwater basins through direct sampling of groundwater and other statistically reliable sampling approaches (Belitz and others, 2003; California State Water Resources Control Board, 2003). The GAMA-PBP is a comprehensive assessment of statewide groundwater quality designed to improve understanding and identification of risks to groundwater resources and to increase the availability of information about groundwater quality to the public. Additional partners in the GAMA-PBP include the California Department of Public Health (CDPH), the California Department of Pesticide Regulation (CDPR), the California Department of Water Resources (CDWR), and local water agencies and well owners (Kulongoski and Belitz, 2004).

The ranges of hydrologic, geologic, and climatic conditions in California were considered in this statewide assessment of groundwater quality. Belitz and others (2003) partitioned the State into 10 hydrogeologic provinces, each with distinctive hydrologic, geologic, and climatic characteristics (fig. 1). All of these hydrogeologic provinces include groundwater basins designated by the CDWR (California Department of Water Resources, 2003). The CDWR-defined groundwater basins generally consist of relatively permeable, unconsolidated deposits of alluvial origin. Eighty percent of California's approximately 16,000 active or standby publicsupply wells or springs listed in the statewide water-quality database maintained by the $\mathrm{CDPH}$ (hereinafter referred to as CDPH sites) are located within CDWR-designated groundwater basins (Belitz and others, 2003). The CDPH Drinking Water Program, which regulates water quality in public-supply wells, was transferred to the SWRCB Division of Drinking Water on July 1, 2014; however, the term 'CDPH sites' is retained in this report for consistency with other GAMA-PBP publications and because the CDPH had jurisdiction over public-supply wells at the time that samples were collected for this study. These basins 


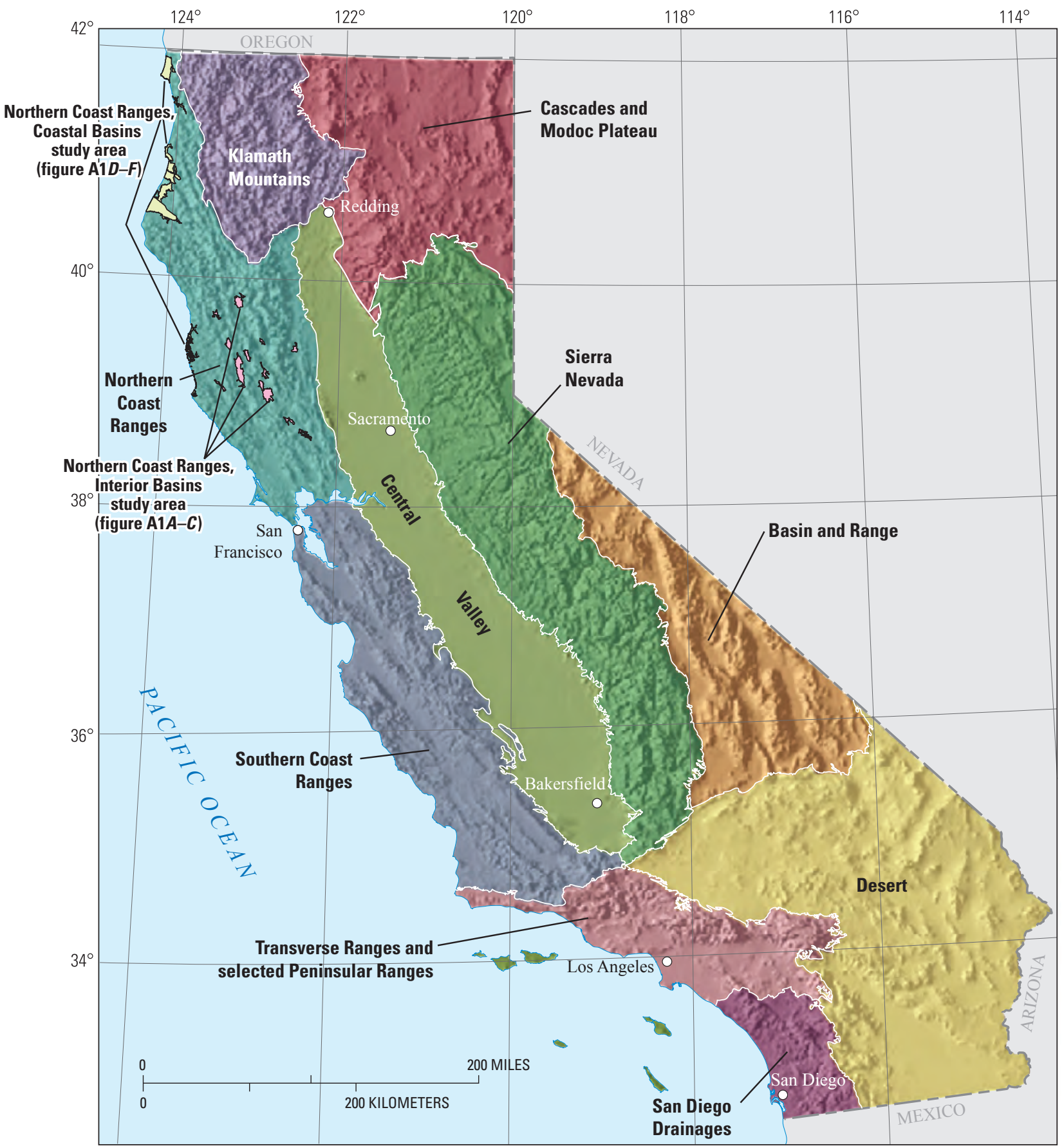

Shaded relief derived from from National Elevation Provinces from Belitz and others, 2003 Dataset (U.S. Geological Survey, 2006) Albers Equal-Area Conic Projection

Figure 1. Location of the Northern Coast Ranges study unit and the California hydrogeologic provinces (modified from Belitz and others, 2003), California GAMA Priority Basin Project. 
were prioritized for sampling on the basis of the number of $\mathrm{CDPH}$ sites in the basin, with secondary consideration given to municipal groundwater use, agricultural pumping, the number of historically leaking underground fuel tanks, and the number of square-mile sections having registered pesticide applications (Belitz and others, 2003). Of the 472 CDWR-designated basins, 116 basins contain approximately 95 percent of $\mathrm{CDPH}$ sites located in CDWR-designated groundwater basins and were defined as priority basins (Belitz and others, 2003). The remaining 356 basins were defined as low-use basins. All of the priority basins, selected low-use basins, and selected areas outside of basins were grouped into 35 GAMA-PBP study units that together represent approximately 95 percent of all CDPH sites. The Northern Coast Ranges (NOCO) study unit is composed of 34 groundwater basins and subbasins in the Northern Coast Ranges hydrogeologic province (fig. 1).

The goal of the GAMA-PBP is to produce three types of water-quality assessments for each study unit: (1) Status: assessment of the current quality of the groundwater resource, (2) Understanding: identification of the natural and human factors affecting groundwater quality and explanation of the relations between water quality and selected explanatory factors, and (3) Trends: detection of changes in groundwater quality over time (Kulongoski and Belitz, 2004). The assessments are intended to characterize the quality of groundwater in the primary aquifer system of the study unit, not the treated drinking water delivered to consumers by water purveyors. The primary aquifer system for a study unit is defined by the depths of the screened or open intervals of the wells listed in the CDPH water-quality database for the study unit. The CDPH water-quality database lists wells and springs used for public drinking-water supplies and includes wells and springs from systems classified as community (such as those in cities, towns, and mobile-home parks), non-transient, non-community (such as those in schools, workplaces, and restaurants), and transient, non-community (such as those in campgrounds and parks). Groundwater quality in the primary aquifer system may differ from that in shallower or deeper parts of the aquifer system. In particular, shallower groundwater may be more vulnerable to contamination from the land surface.

In addition to being selected for study as part of the GAMA-PBP, the Northern Coast Ranges (NOCO) study unit (fig. 1) was considered a high priority for sampling to complete an assessment of groundwater quality in the California Coastal Basins Principal Aquifer of the United States (U.S. Geological Survey, 2003) by the USGS National Water-Quality Assessment (NAWQA) Program (Lapham and others, 2005). As a result, the NAWQA Program collaborated with the GAMA-PBP to assess groundwater quality in the NOCO study unit.

\section{Purpose and Scope}

The purposes of this report are to provide a (1) study unit description: description of the hydrogeologic setting of the NOCO study unit, (2) status assessment: assessment of the status of the current (2009) quality of groundwater in the primary aquifer system in the NOCO study unit, and (3) understanding assessment: identification of the natural and human factors affecting groundwater quality and explanation of the relations between water quality and selected explanatory factors. Assessments are made for chemical constituents only; microbiological indicators of groundwater quality are not discussed in this report.

The status assessment includes analyses of water-quality data for 58 sites selected by the USGS for spatial coverage of 1 site per grid cell (hereinafter referred to as USGS-GAMA grid sites) across the NOCO study unit and water-quality data from the CDPH database for samples collected between June 1, 2006, and June 1, 2009, at 276 sites. The details of sample collection, analysis, and quality-assurance procedures for the NOCO study unit and all of the water-quality data collected by the USGS are reported by Mathany and others (2011). GAMA-PBP status assessments are designed to provide a statistically robust characterization of groundwater quality in the primary aquifer system at the study-unit scale (Belitz and others, 2003). The statistically robust design also allows basins to be compared and results to be synthesized regionally and statewide. This report describes methods used in designing the sampling network, identifying CDPH data for use in the status assessments, estimating aquifer-scale proportions of relative-concentrations, and assessing the status of groundwater quality by statistical and graphical approaches.

To provide context, the water-quality data discussed in this report are compared to California and Federal regulatory and nonregulatory benchmarks for drinking water by using relative-concentrations (the ratio of the concentration of a constituent in groundwater to the benchmark concentration). The assessments in this report are intended to characterize the quality of untreated groundwater resources in the primary aquifer system within the study unit, not the drinking water delivered to consumers by water purveyors. This study does not attempt to evaluate the quality of water delivered to consumers; after withdrawal from the ground, water typically is treated, disinfected, or blended with water from other sources to maintain acceptable water quality. Regulatory benchmarks apply to drinking water that is delivered to the consumer, not to untreated groundwater.

The understanding assessment is based on water-quality data and data for potential explanatory factors from the 58 sites sampled by the USGS for the GAMA Program. The potential explanatory factors affecting water quality in the primary aquifer system evaluated are land use (including density of septic tanks and leaking or formerly leaking underground fuel tanks), well construction (well depth and depth to the top of the perforated interval in the well), hydrologic conditions (aridity index, field water temperature, and distance to nearest known geothermal reservoir), $\mathrm{pH}$, dissolved oxygen concentration, groundwater age distribution, and geochemical conditions. Connections between potential explanatory factors and water quality were evaluated by using statistical tests for correlations and by analysis of graphical relations. 


\section{Hydrogeologic Setting of the Northern Coast Ranges Study Unit}

The NOCO study unit covers approximately 633 square miles $\left(\mathrm{mi}^{2}\right)\left(1,639\right.$ square kilometers; $\left.\mathrm{km}^{2}\right)$ in Napa, Sonoma, Lake, Colusa, Mendocino, Glenn, Humboldt, and Del Norte Counties in northern California. The NOCO study unit lies within the Northern Coast Ranges hydrogeologic province (fig. 1; Belitz and others, 2003) and includes 35 groundwater basins and subbasins (California Department of Water Resources, 2003). For the purpose of this study, these 35 groundwater basins and subbasins were grouped into 2 study areas based on location. The groundwater basins and subbasins located inland, not adjacent to the Pacific Ocean, were aggregated into the Interior Basins study area. The groundwater basins and subbasins adjacent to the Pacific Ocean were aggregated into the Coastal Basins study area. As part of the GAMA-PBP, untreated groundwater samples were collected from 58 sites in the NOCO study unit from June 1, 2009, to October 8, 2009 (Mathany and others, 2011).

\section{Northern Coast Ranges-Interior Basins Study Area}

The Interior Basins study area (hereinafter referred to as the NOCO-IN study area) is $256 \mathrm{mi}^{2}$ in area and contains 24 CDWR-defined basins (California Department of Water Resources, 2004a-w, ii). The NOCO-IN study area is located in the Coast Ranges Mountains region of northern California stretching approximately 25 to 60 miles (mi) inland of the Pacific Ocean and 60 to 130 mi north of San Francisco. The study area consists primarily of noncontiguous inland valleys whose boundaries are the surrounding hills and (or) mountains. In the central part of the study area, some of the inland valleys share Clear Lake or other lakes as a border (fig. 2B). Landsurface altitudes in the study area range from about 475 feet above mean sea level ( $\mathrm{ft}$ above msl) near the town of Hopland, to over 4,200 ft above msl on Mount Konocti, located just east of the town of Kelseyville (fig. A1B).

In the NOCO-IN study area, the climate is classified as Mediterranean, with warm to hot, dry summers and cold, wet winters (National Oceanic and Atmospheric Administration, 2011). Most precipitation in the study area occurs in the fall and winter months, with average annual precipitation ranging from about 22 inches (in.) near the town of Stonyford to more than 65 in. near the town of Laytonville (fig. A1A) (California Department of Water Resources, 2004i, r; U.S. Department of Commerce, 2011).

The main surface drainage features of the study area are the Eel, Russian, and Navarro Rivers and their tributaries, all of which have their headwaters outside of the study area and terminate in the Pacific Ocean (figs. A1A-A1C). Large creeks (Outlet, Mill, Stoney, Scotts, St. Helena, and Pope) and numerous small creeks drain the valleys of the study area.
The primary aquifer system in the study area is in Quaternary alluvial groundwater basins made up of sand, silt, gravel, and clay eroded from the surrounding hills. These deposits interfinger with and grade into alluvial fan and terrace deposits along the sides of the valleys, and into older, more consolidated alluvium at depth, and in some valleys, these deposits grade into finer-grained lake deposits towards the center of the basins. Groundwater conditions are mostly unconfined, with some confined areas towards the center of valleys and at depth. The major rock types surrounding the alluvial valleys are the Jurassic-Cretaceous Franciscan Formation (mudstone, greywacke sandstones, and chert) and ophiolitic and metamorphosed volcanic rocks (Muir and Webster, 1977; Farrar, 1986; California Department of Water Resources, 2004e-w). In groundwater basins near Clear Lake, groundwater is also found in Quaternary volcanic flow rocks and thin volcanic ash layers/lenses interbedded with low-permeability sediments (Soil Mechanics and Foundation Engineers, Inc., 1967; Earth Sciences Associates, 1978) (fig. 3B).

The general direction of groundwater flow in the study area is from areas of high topographic relief to the center of the valleys (areas of low topographic relief), following the direction of surface-water features. The study area has several northwest trending faults and fault zones, which act as hydrologic barriers to groundwater movement (California Department of Water Resources, 2004a-w; fig. 3C).

Groundwater recharge in the study area occurs from a mixture of ambient sources, including direct percolation of precipitation and irrigation waters, infiltration of runoff from surrounding hills/areas, and seepage from rivers and creeks (California Department of Water Resources, 2004a-w).

Most of the central and southern parts of the NOCO-IN study area are located within the boundaries of the Geysers-Clear Lake area (fig. 3C), known to be an active geothermal region of northern California (Goff and others, 1993; Hodgson, 2003; California Department of Water Resources, 2004a-d; U.S. Geological Survey, 2004; California Department of Conservation, 2013). The Geysers-Clear Lake area is characterized by recent volcanism (late-Pliocene to early Holocene), high heat flux, and high geothermal gradients that are enhanced locally by fault-controlled zones of convective heat (geothermal fluid) transport (Wood and Kienle, 1992; Stimac and others, 1997; Erkan and others, 2005; Smithsonian Institution, National Museum of Natural History, Global Volcanism Program, 2013). Hydrothermal systems (rather than one large underlying geothermal reservoir) are known to influence the groundwater within the Geysers-Clear Lake area (Goff and others, 1993).

Three geothermal water types have been identified within the Geysers-Clear Lake area: thermal meteoric, steam condensate, and connate/metamorphic (Donnelly-Nolan and others, 1993; Goff and others, 1993; Peters, 1993). Thermal meteoric water is most commonly found near the main mass of the Clear Lake volcanic field and issues from Quaternary volcanic rocks. These waters appear to be a mixture of highertemperature geothermal water that has resided at depth for 

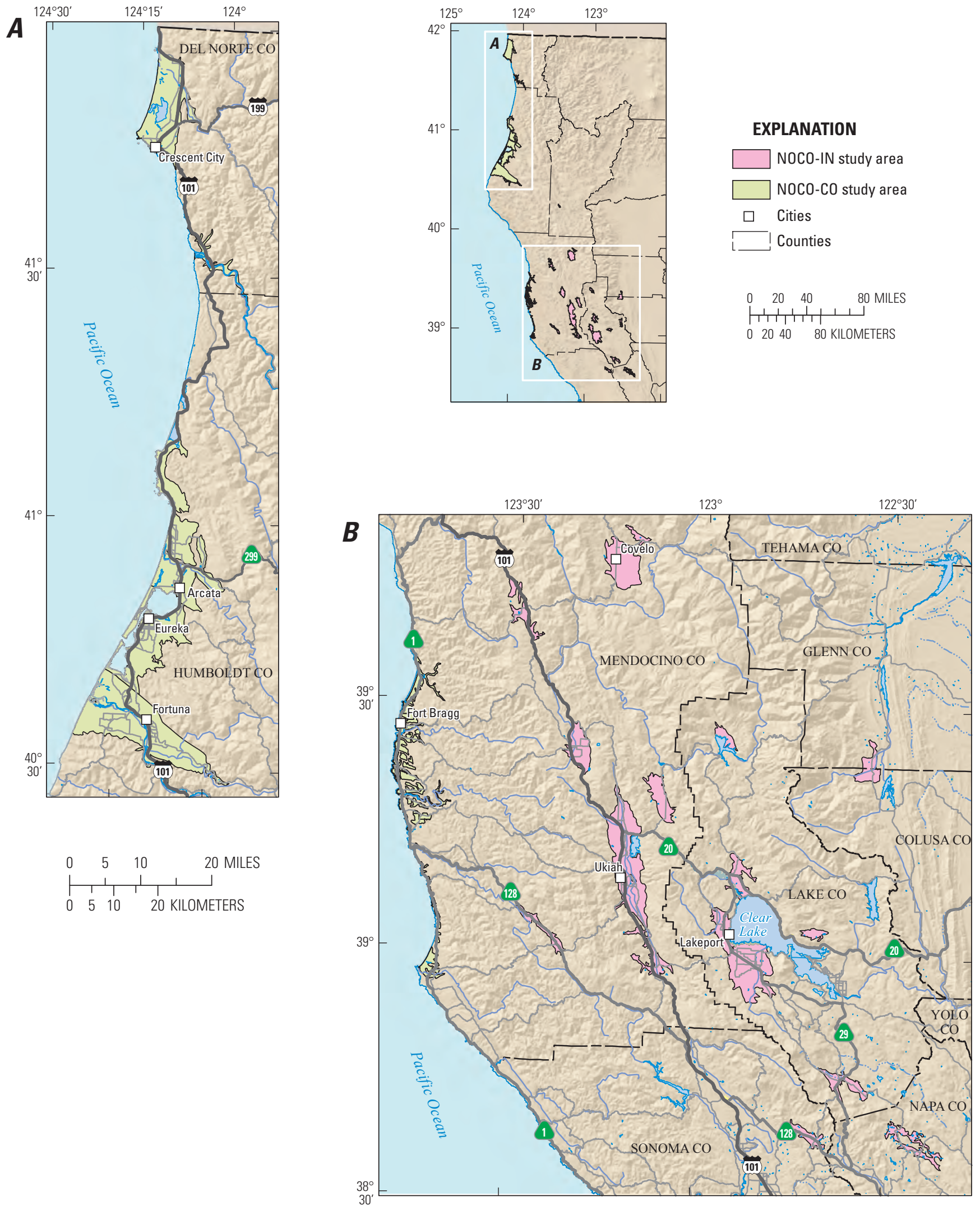

Figure 2. Location of the $(A)$ Coastal Basins (NOCO-CO) and $(B)$ Interior Basins (NOCO-IN) study areas, major cities and towns, major roads, and hydrologic features in the Northern Coast Ranges study unit, 2009, California GAMA Priority Basin Project. 


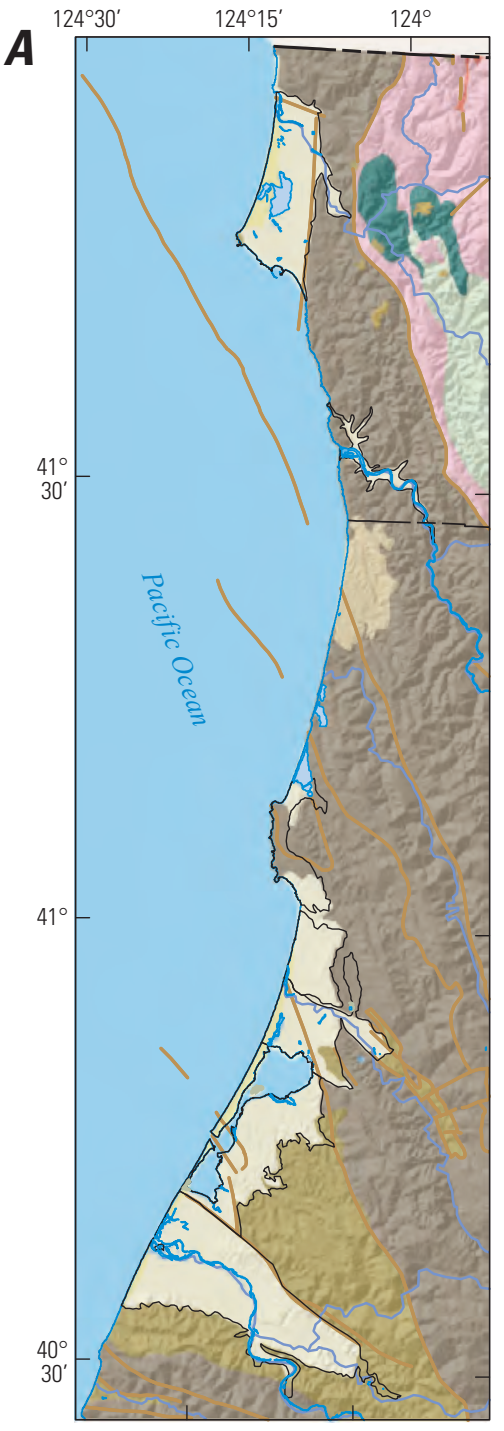

Geology from Saucedo and others, 2000

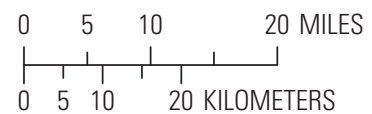

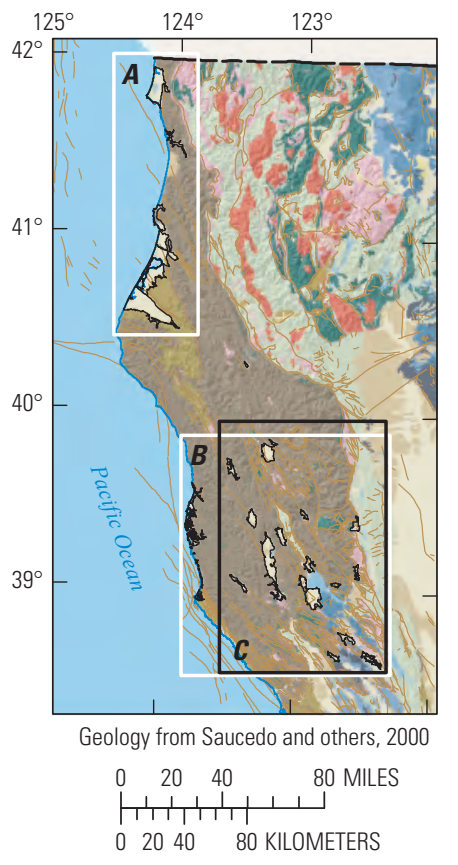

\section{EXPLANATION}

7. NOCO study unit

Franciscan complex

Plio-Pleistocene sediment Quaternary alluvium Quaternary other sediment Quarternary, mafic volcanics Pyroclastic volcanics Tertiary, mafic volcanics Tertiary nonmarine sediment Tertiary marine sediment Granitic rocks

Metamorphic other Metasediment Ultramafic/mafic Fault

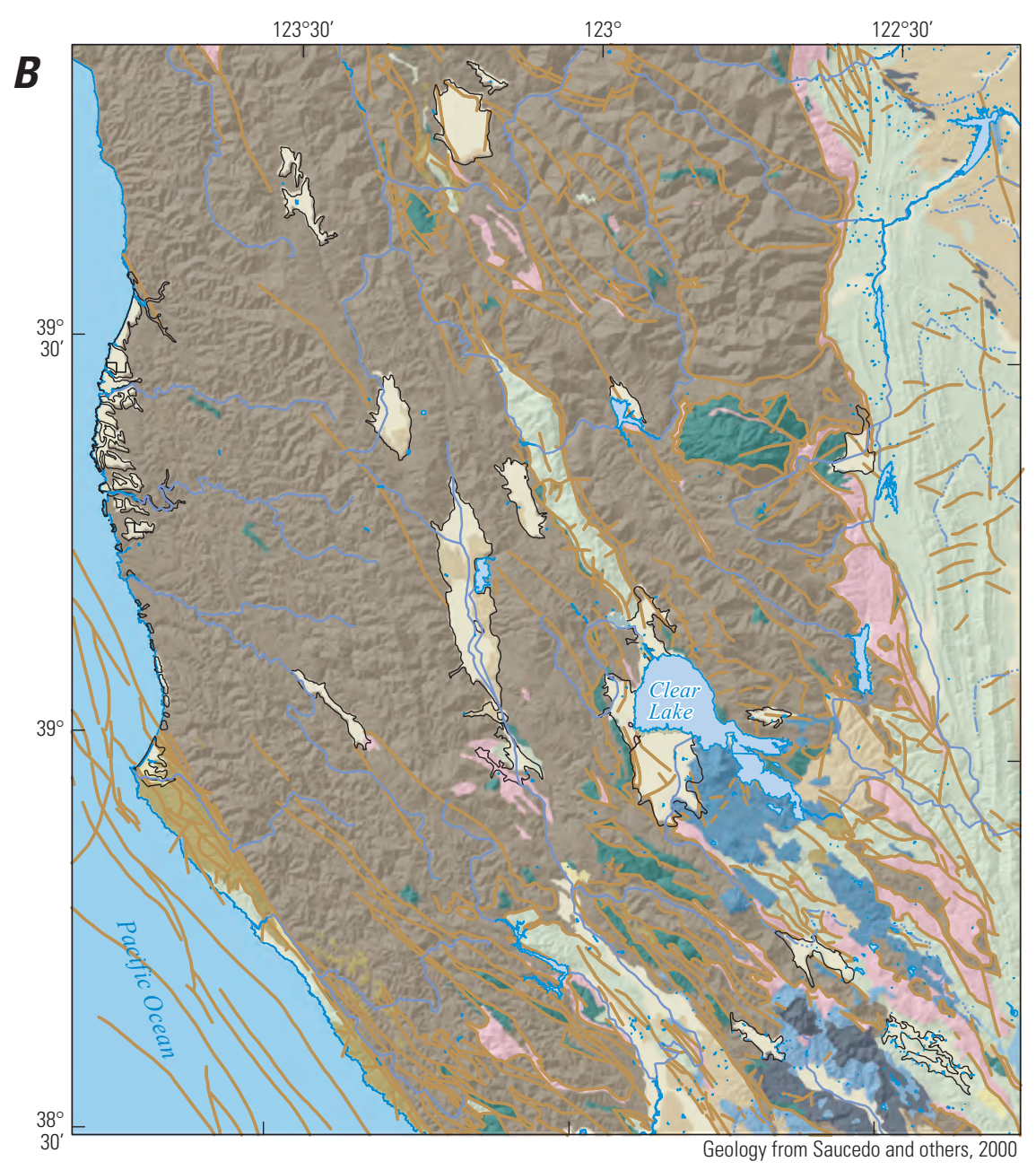

Figure 3. Geologic formations and locations of the $(A)$ Coastal Basins study area, $(B)$ and $(C)$ Interior Basins study area, locations of hot springs and geothermal wells, and approximate boundaries of the Napa and Sonoma Valleys and the Geysers Steam Field, Northern Coast Ranges study unit, 2009, California GAMA Priority Basin Project. 


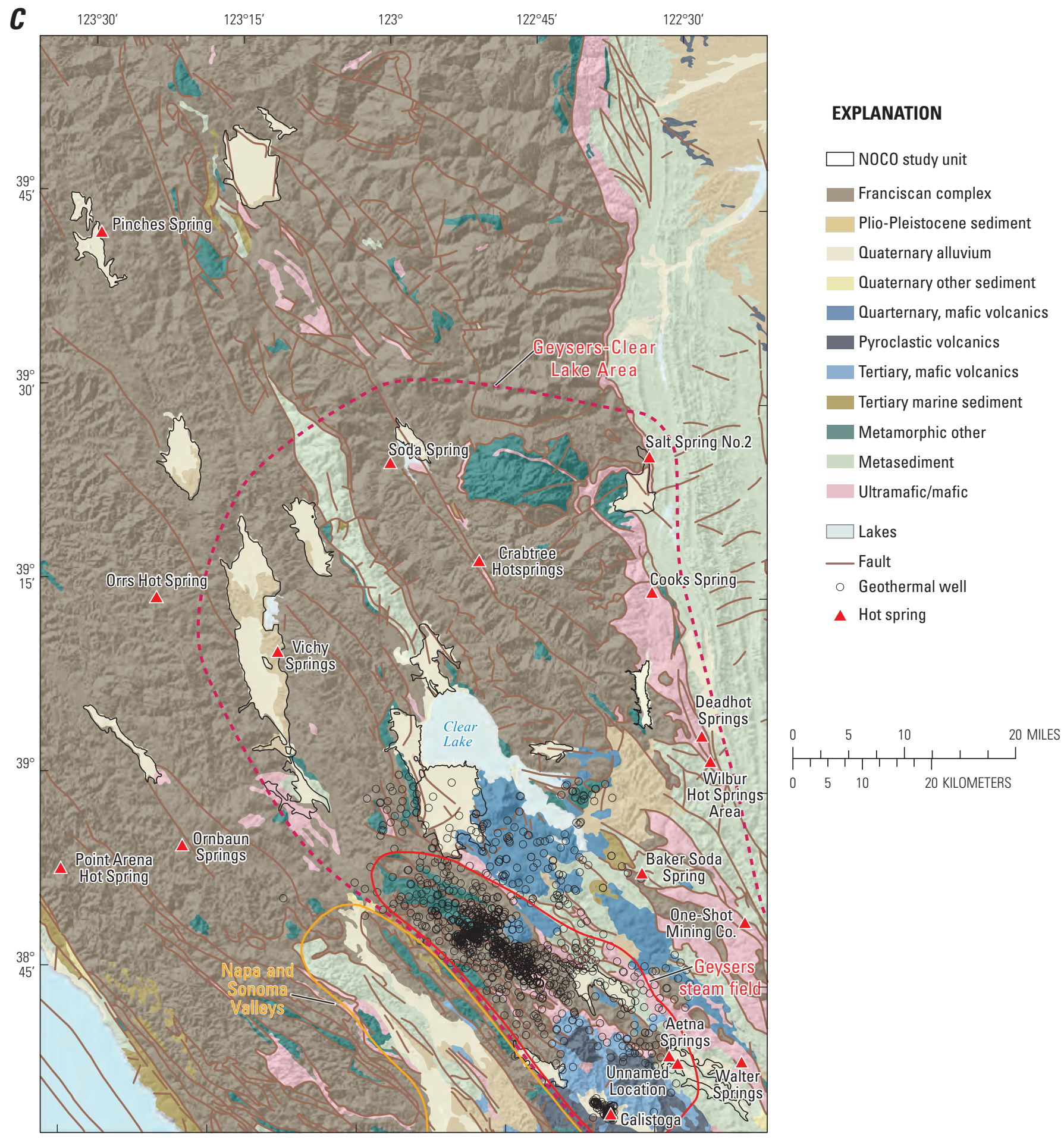

Geology from Saucedo and others, 2000

Figure 3. - Continued 
relatively short time periods and a cooler, near-surface meteoric water. Steam condensate waters are most commonly found near the Geysers steam field along the southwestern portion of the Geysers-Clear Lake area (fig. 3C). These waters are a mixture of groundwater, condensed steam from an underlying hydrothermal system, and heated groundwater. Connate and metamorphic (a subclass of connate) waters are commonly found in the eastern reaches of the Geysers-Clear Lake area. Connate waters typically issue from rocks of the Great Valley sequence and are most common in the eastern Clear Lake region, whereas metamorphic waters typically issue from rocks of the Franciscan Formation near the main Clear Lake volcanic field. These three geothermal water types are unique in distribution and origin, but they share common chemical signatures of hydrothermal activity - near-neutral $\mathrm{pH}$ and elevated concentrations of boron, bromide, arsenic, and lithium (Donnelly-Nolan and others, 1993; Goff and others, 1993; Peters, 1993).

The NOCO-IN study area is just north of of the Napa and Sonoma Valleys (fig. 3C), a hydrothermally active area with similar Tertiary to Holocene age volcanic processes as in the Geysers-Clear Lake area (U.S. Geological Survey, 2004). Similar to the Geysers-Clear Lake area, the Napa and Sonoma Valleys are characterized by localized hydrothermal systems associated with fault zones, high geothermal gradients, and high heat flux (Kulongoski and others, 2010). A study by Forrest and others (2013) used USGS-GAMA data from the Napa and Sonoma Valleys (North San Francisco Bay study unit: Kulongoski and others, 2006) to determine which constituents were most indicative of hydrothermal contamination of public supply wells. The study identified water temperature, concentrations of boron, arsenic, lithium, and chloride, and helium isotope ratios as the constituents that were most useful in evaluating the contribution of the hydrothermal system to the public supply wells.

\section{Northern Coast Ranges-Coastal Basins Study Area}

The Coastal Basins study area (hereinafter referred to as the NOCO-CO study area) is $377 \mathrm{mi}^{2}$ in area and contains 11 CDWR-defined basins and subbasins (California Department of Water Resources, 2004x-hh). The study area is located along the northern California coast beginning north of Point Arena and extending to the Oregon border (figs. A $1 D-\mathrm{A} 1 F$ ). The study area has three distinct sections (northern, central, and southern), each bordered on the west by the Pacific Ocean and on the north, east, and south by the hills surrounding the coastal valleys (fig. $2 A$ ). Land-surface altitudes in the study area range from sea level where the study area boundary touches the Pacific Ocean, to approximately $500 \mathrm{ft}$ above msl in the hills above the city of Fortuna (fig. 2).

In the NOCO-CO study area, the climate is classified as coastal (National Oceanic and Atmospheric Administration, 2011), with cool to mild summers and cold, wet winters. Coastal fog and low clouds are common throughout the year.
Average annual precipitation in the study area ranges from about $38 \mathrm{in}$. near the town of Trinidad to about $79 \mathrm{in}$. near the town of Klamath (figs. A1D, A1E; U.S. Department of Commerce, 2011).

The major surface drainage features of the study area are the Smith, Klamath, Mad, Eel, Noyo, and Big Rivers and their tributaries, all of which have their headwaters outside of the study area and terminate in the Pacific Ocean (figs. A1D-A $1 F$ ).

The primary aquifer system in the northern part of the study area principally occurs in the Smith River Plain, a marine terrace made up of Holocene alluvial fan and floodplain deposits; in the Pleistocene terrace deposits; and in the Pleistocene Battery Formation (California Department of Water Resources, 1987, 2004x). The Smith River Plain and the Pleistocene terrace deposits are included in Quaternary alluvium and Pleistocene-Pliocene nonmarine deposits, and the Pleistocene Battery Formation is mapped as Tertiary marine sediment (fig. 3A). In the central part of the study area, the primary aquifer system occurs in groundwater basins consisting of alluvial deposits associated with drowned river mouths of the Klamath, Mad, and Eel Rivers. The alluvial deposits consist of Holocene alluvium, dune sand, the Pleistocene Hookton Formation, and the deeper PliocenePleistocene Carlotta Formation (Johnson, 1978; California Department of Water Resources, 2004y-dd). The primary aquifer system in the southern part of the study area is in the Fort Bragg Terrace deposits. These deposits are discontinuous, uplifted, and dissected Pleistocene marine terraces along the Pacific Ocean. The terrace deposits consist of Tertiary marine sediment, dune sand, and semi-consolidated clay, silt, sand, and gravel derived from adjacent formations (largely the Franciscan complex) that are up to 150 feet (ft) thick (California Department of Water Resources, Northern District, 1982; California Department of Water Resources, 2004ff-gg).

The general direction of groundwater-flow in the study area is from east to west towards the Pacific Ocean. In the northern part of the study area, dune sand accumulation has created Lake Earl, which acts as a restrictive structure to groundwater movement (fig. A1D). In the central and southern parts of the study area, several northwest trending faults and fault zones act as hydrologic barriers (California Department of Water Resources, 2004x-gg; fig. 3A).

Groundwater recharge in the study area comes from a mixture of ambient sources including direct percolation of precipitation and irrigation waters, infiltration of runoff from surrounding hills/areas, seepage from rivers and creeks, and subsurface inflow (from non-alluvial geologic units that underlie the alluvial basins) (California Department of Water Resources, 2004x-gg).

The groundwater basins in the northern and central parts of the study area are in hydraulic connection with the Pacific Ocean, and seawater extends landward as a wedge underneath fresh groundwater in some of the basins. In the southern part of the study area, the uplifted terrace deposits prevent hydraulic connection between groundwater basins and the Pacific Ocean (California Department of Water Resources, 2004x-gg). 


\section{Methods}

This section describes the methods used for the status assessment and understanding assessment for water quality in the NOCO study unit. Methods used for compiling data for the potential explanatory factors are described in appendix B.

\section{Status Assessment}

The status assessment provides a spatially unbiased assessment of groundwater quality in the primary aquifer system of the NOCO study unit. Methods used for the status assessment included (1) assembling water-quality benchmarks and calculating relative-concentrations, (2) assembling datasets for use in the status assessment, (3) selecting constituents for additional evaluation, and (4) calculating aquifer-scale proportions for these constituents.

\section{Relative-Concentrations and Water-Quality Benchmarks}

To provide context for the groundwater-quality data, concentrations of constituents measured in the untreated groundwater were compared to benchmarks established by the U.S. Environmental Protection Agency (USEPA) and CDPH for evaluation of the quality of drinking water (U.S. Environmental Protection Agency, 2008, 2009a, b, 2012; California Department of Public Health, 2006, 2008, 2010). The benchmarks used for each constituent were selected in the following order of priority:

1. Regulatory, health-based CDPH and USEPA maximum contaminant levels (MCL-CA and MCL-US) and action levels (AL-US).

2. Nonregulatory, aesthetic-based CDPH and USEPA secondary maximum contaminant levels (SMCL-CA and SMCL-US). For constituents with recommended and upper SMCL-CA levels, the values for the upper levels were used.

3. Nonregulatory, health-based CDPH notification levels (NL-CA), USEPA lifetime health advisory levels (HAL-US), and USEPA risk-specific doses for a risk of 1 in 100,000 (RSD5-US). Risk-specific doses for 1 in $100,000\left(1\right.$ in $\left.10^{5}\right)$ were calculated by dividing USEPA values for estimated excess lifetime cancer risk from drinking water of 1 in $10^{4}$ by 10 .

For constituents with multiple types of benchmarks, this hierarchy may not result in selection of the benchmark with the lowest concentration. Additional information on the types of benchmarks and listings of the benchmarks for all constituents analyzed is provided by Mathany and others (2011).

Groundwater-quality data are presented as relativeconcentrations, the concentrations of constituents measured in groundwater relative to regulatory and nonregulatory benchmarks used to evaluate drinking-water quality:

$$
\text { Relative-concentration }=\frac{\text { Sample concentration }}{\text { Benchmark concentration }} .
$$

Relative-concentrations less than 1.0 indicate a sample concentration less than the benchmark, and relativeconcentrations greater than 1.0 indicate a sample concentration greater than the benchmark. The use of relative-concentrations also permits comparison on a single scale of constituents present at a wide range of concentrations. Relativeconcentrations can only be computed for constituents with water-quality benchmarks; therefore, constituents without water-quality benchmarks are not included in the status assessment.

The four microbial indicators analyzed in samples from the NOCO study unit, total coliforms, Escherichia coli (E. coli), and coliphage (somatic and f-specific), have water-quality benchmarks, but are not included in the status and understanding assessments because the results will be presented in 1 report for all 25 GAMA-PBP public-supply aquifer study units (Carmen Burton, U.S. Geological Survey, written commun., 2014).

Toccalino and others (2004), Toccalino and Norman (2006), and Rowe and others (2007) previously used the ratio of measured sample concentration to the benchmark concentration [either MCL-US or health-based screening levels (HBSLs)] and defined this ratio as the benchmark quotient. HBSLs were not used in this report because HBSLs are not currently used as benchmarks by California drinkingwater regulatory agencies. Because different water-quality benchmarks may be used to calculate relative-concentrations and benchmark quotients, the terms are not interchangeable.

For ease of discussion, relative-concentrations of constituents were classified into low, moderate, and high categories:

[Abbreviations: $>$, less than; $\leq$, greater than or equal to]

\begin{tabular}{lcc}
\hline Category & $\begin{array}{c}\text { Relative-concentrations } \\
\text { for organic and special- } \\
\text { interest constituents }\end{array}$ & $\begin{array}{c}\text { Relative-concentrations } \\
\text { for inorganic constituents }\end{array}$ \\
\hline High & $>1$ & $>1$ \\
Moderate & $>0.1$ and $\leq 1$ & $>0.5$ and $\leq 1$ \\
Low & $\leq 0.1$ & $\leq 0.5$ \\
\hline
\end{tabular}

For organic and special-interest constituents, a relativeconcentration of 0.1 was used as a threshold to distinguish between low and moderate relative-concentrations for consistency with other studies and reporting requirements (U.S. Environmental Protection Agency, 1998; Toccalino and others, 2004). For inorganic constituents, which tend to be more prevalent than organic constituents in groundwater (Toccalino and others, 2010), a relative-concentration of 0.5 was used as a threshold to distinguish between low and moderate relativeconcentrations. The primary reason for using a higher threshold 
for inorganic constituents was to focus attention on those inorganic constituents that are of most immediate concern (Fram and Belitz, 2012). Although more complex classifications could be devised based on the properties and sources of individual constituents, use of a single moderate/low threshold value for each of the two major groups of constituents provided a consistent and objective criteria for distinguishing constituents at moderate rather than low concentrations.

\section{Datasets Used for Status Assessment}

Two datasets were used in the status assessments: (1) data from USGS-GAMA grid sites and (2) data combined from USGS-GAMA grid sites and CDPH sites. This section explains how each dataset was assembled. Comparisons of USGS-GAMA and CDPH data are presented in appendix D.

\section{USGS-GAMA Grid Sites}

The grid-based calculations of aquifer-scale proportions used data from 58 sites sampled by the USGS for spatial coverage of one well per grid cell across the study unit (grid sites). Detailed descriptions of the methods used to identify sites for sampling are given in Mathany and others (2011). Briefly, each study area was divided into equal-area grid cells (Interior Basins, $8.5-\mathrm{mi}^{2}\left[22.0-\mathrm{km}^{2}\right]$ cells and Coastal Basins, $12.5-\mathrm{mi}^{2}\left[32.4-\mathrm{km}^{2}\right]$ cells), and in each cell, one site was randomly selected to represent the cell (Scott, 1990) (figs. 4, A1A-A1F). Sites were selected from those in the statewide database of public-supply wells maintained by the $\mathrm{CDPH}$. If a cell had no accessible sites listed in the CDPH water-quality database, then appropriate sites were selected from the USGS Groundwater Site Inventory (GWSI) database. The NOCO study unit contained 60 grid cells, and the USGS sampled sites in 58 of those cells. Of the 58 USGS-GAMA grid sites, 31 were listed in the CDPH water-quality database, and 27 were non-CDPH sites perforated at depths similar to the depths of CDPH sites in their respective cells. One of the USGS-GAMA grid sites that was listed in the CDPH database was a spring. USGS-GAMA grid sites were named with an alphanumeric GAMA-ID consisting of a prefix identifying the study area and a number indicating the order of sample collection (figs. A $1 A-\mathrm{A} 1 F$ ). The following prefixes were used to identify the study area: NOCO-IN (Interior Basins study area) and NOCO-CO (Coastal Basins study area).

Samples collected from USGS-GAMA grid sites were analyzed for 234 constituents (table 1). The collection, analysis, and quality-control data for the constituents listed in table 1 are described by Mathany and others (2011). Because samples from all USGS-GAMA grid sites were analyzed for the full suite of constituents, it was not necessary to supplement the grid site dataset with data from the CDPH database, as was done in the status assessments in many other GAMA-PBP study units (Landon and others, 2010; Burton and others, 2011; Kulongoski and Belitz, 2011). The two grid cells without USGS-GAMA grid sites had no CDPH sites with water-quality data for the 3-year interval June 1, 2006, through June 1, 2009.
Table 1. Constituent classes and numbers of constituents analyzed for the 58 sites sampled, Northern Coast Ranges study unit, 2009, California GAMA Priority Basin Project.

[GAMA, Groundwater Ambient Monitoring and Assessment Program]

\begin{tabular}{|c|c|}
\hline Constituent class & $\begin{array}{c}\text { Number of } \\
\text { constituents }^{1}\end{array}$ \\
\hline \multicolumn{2}{|l|}{ Inorganic constituents } \\
\hline Trace elements & 23 \\
\hline $\begin{array}{l}\text { Major and minor ions, alkalinity, specific } \\
\text { conductance, and total dissolved solids }\end{array}$ & 13 \\
\hline Nutrients and dissolved organic carbon & 6 \\
\hline Uranium and other radioactive constituents ${ }^{2}$ & 7 \\
\hline \multicolumn{2}{|l|}{ Organic constituents } \\
\hline Volatile organic compounds & 85 \\
\hline$\underline{\text { Pesticides and pesticide degradates }}$ & 83 \\
\hline \multicolumn{2}{|l|}{ Special-interest constituent } \\
\hline Perchlorate & 1 \\
\hline \multicolumn{2}{|l|}{ Geochemical and age-dating tracers } \\
\hline Dissolved oxygen, $\mathrm{pH}$, temperature, and turbidity & 4 \\
\hline Tritium & 1 \\
\hline $\begin{array}{l}\text { Noble gases (helium, neon, argon, krypton, xenon), } \\
{ }^{3} \mathrm{He} /{ }^{4} \mathrm{He} \text { of helium, and tritium }\end{array}$ & 7 \\
\hline$\delta^{2} \mathrm{H}$ and $\delta^{18} \mathrm{O}$ of water & 2 \\
\hline Carbon-14 and $\delta^{13} \mathrm{C}$ of dissolved carbonates & 2 \\
\hline Sum & 234 \\
\hline
\end{tabular}

${ }^{1}$ All sites also were analyzed for 12 pharmaceutical compounds and 4 microbial indicators. Assessment results for these constituents are not being presented for individual study units, therefore, they are not included in the count of constituents. A statewide synthesis of GAMA Priority Basin Project results for pharmaceuticals was presented by Fram and Belitz (2011), and a synthesis of results for microbial indicators will be presented at a later date (Carmen Burton, U.S. Geological Survey California Water Science Center, written commun., 2013).

${ }^{2}$ Activities of radon-222, radium, gross alpha and gross beta particles, lead-210, and polonium-210 and uranium concentrations were measured. Gross alpha and gross beta particle activities were measured after 72-hour and 30-day holding times; data from the 30-day measurement are used in this report. Radium activity equals the sum of the two isotopes measured: radium-226 and radium-228.

\section{Additional Data Used for Spatially Weighted Calculation}

The spatially weighted calculations of aquifer-scale proportions of relative-concentrations used data from the 58 USGS-GAMA grid sites and from the 276 sites in the CDPH water-quality database having water-quality data during the 3-year interval June 1, 2006, through June 1, 2009. For the 27 sites with USGS-GAMA and CDPH data, only the USGSGAMA data were used. Many of the 249 sites having only $\mathrm{CDPH}$ data had data for a limited number of constituents. For example, 162 sites had data for nitrate, but only 72 sites had data for at least 1 trace element. Water-quality data collected by the CDPH are available from the SWRCB's publicallyaccessible Internet database GeoTracker GAMA (California State Water Resources Control Board, 2009, website at https:// geotracker.waterboards.ca.gov/gama/). 

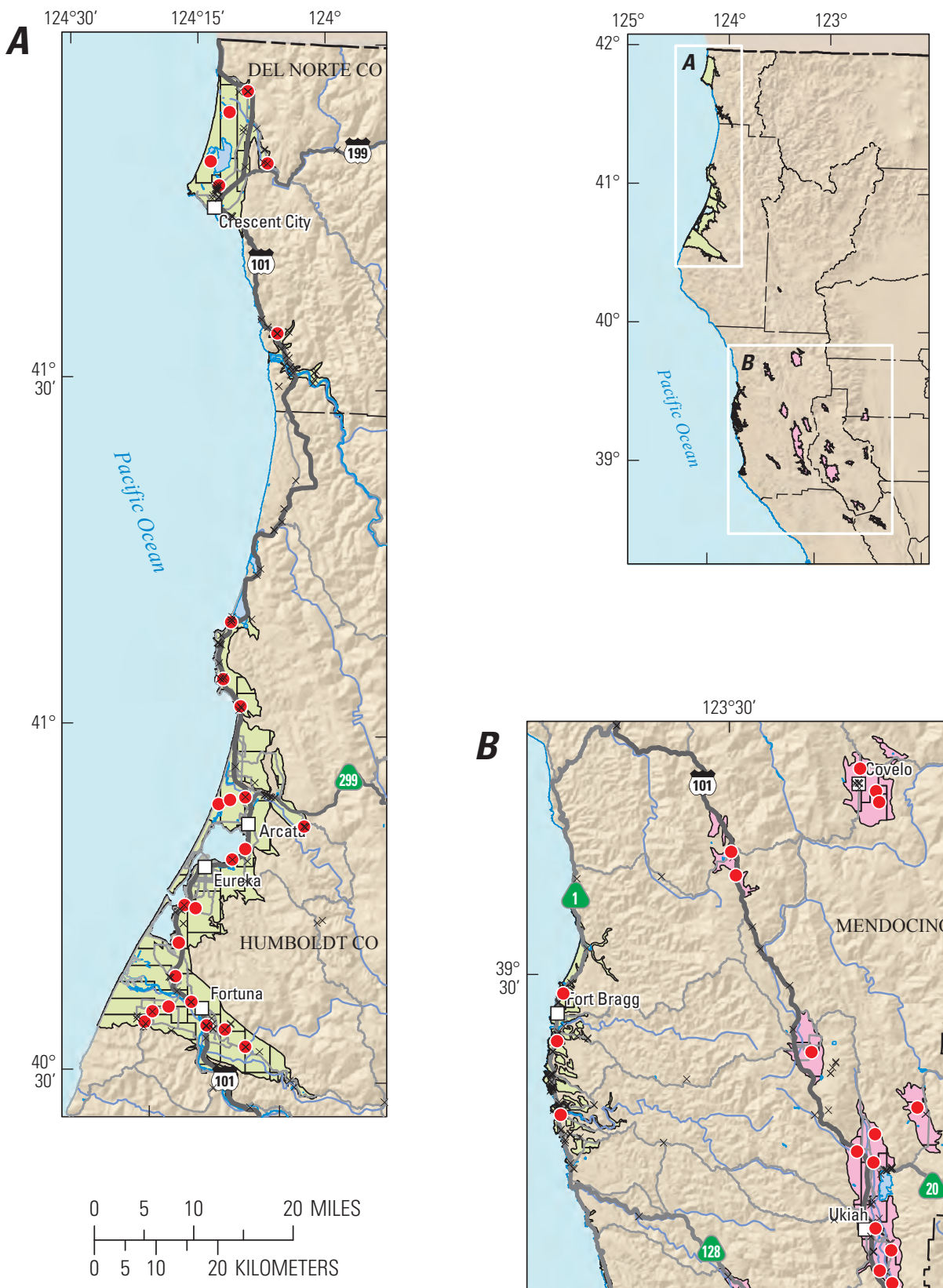

\section{EXPLANATION}

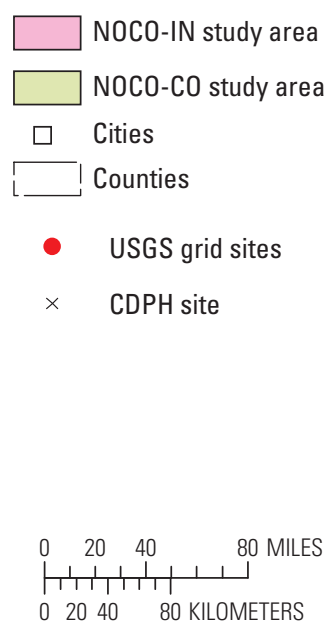

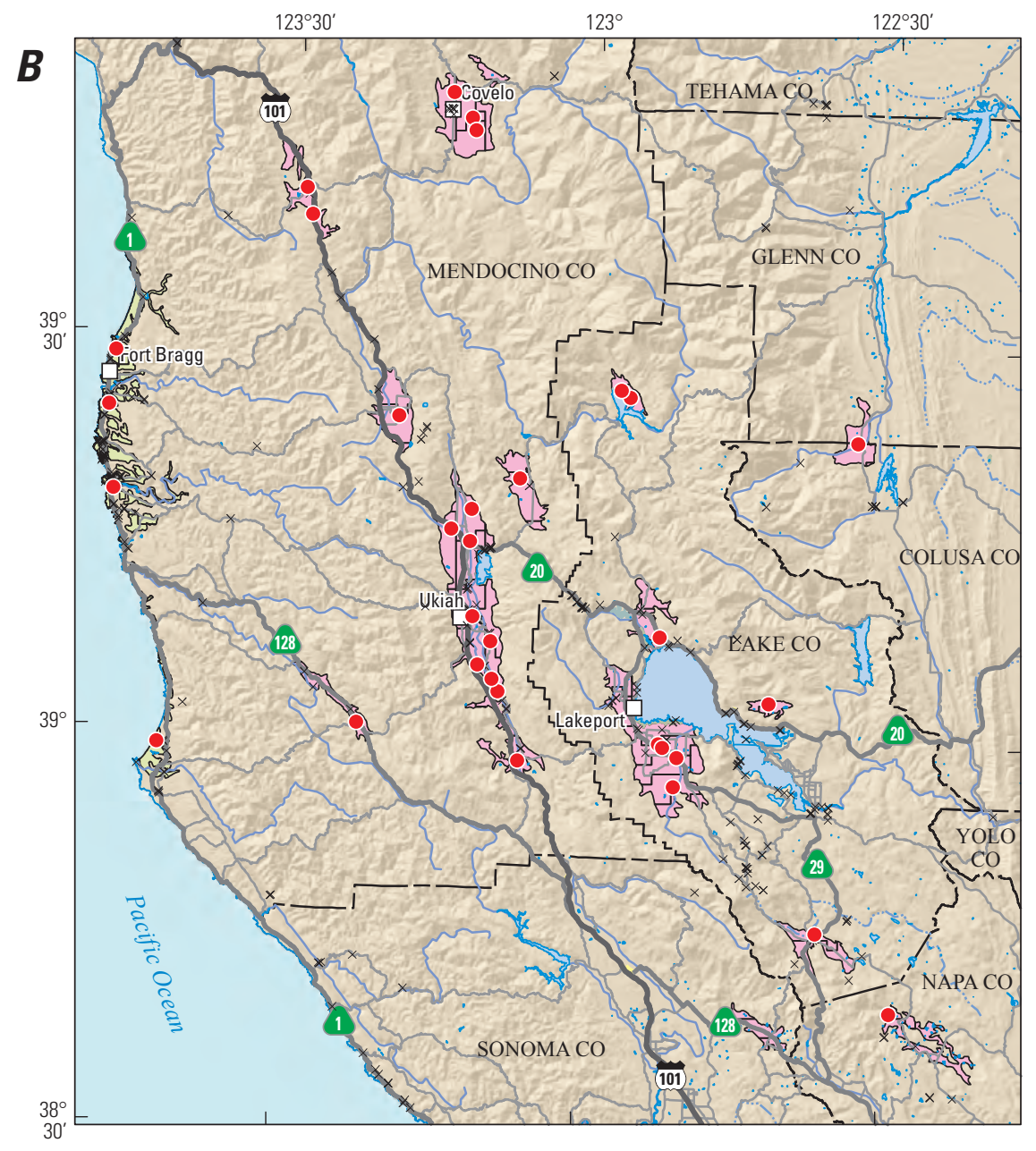

Figure 4. Locations of study area grid cells, USGS-GAMA grid sites, and CDPH sites, Northern Coast Ranges study unit, 2009, California GAMA Priority Basin Project. [NOCO-IN, Interior Basins study area; NOCO-CO, Coastal Basins study area] 
Selection of Constituents for Additional

\section{Evaluation in the Status Assessment}

As many as 234 constituents were analyzed by USGSGAMA in samples from sites in the NOCO study unit as part of the status assessment (table 1); however, only subsets of these constituents were identified for additional evaluation in this report. Of the 238 constituents analyzed, 114 constituents did not have benchmarks (table 2). Because relativeconcentrations cannot be calculated for constituents without benchmarks, these 114 constituents were not evaluated in this report. The 126 constituents having benchmarks were assessed,

Table 2. Numbers of constituents analyzed and detected in each constituent class with each type of benchmark, Northern Coast Ranges study unit, 2009, California GAMA Priority Basin Project.

[GAMA, Groundwater Ambient Monitoring and Assessment Program]

\begin{tabular}{|c|c|c|c|c|c|c|c|c|}
\hline \multirow{3}{*}{ Benchmark type } & \multicolumn{6}{|c|}{ Groups of inorganic constituents } & \multirow{2}{*}{\multicolumn{2}{|c|}{$\begin{array}{c}\text { Sum of inorganic } \\
\text { constituents }\end{array}$}} \\
\hline & \multicolumn{2}{|c|}{$\begin{array}{l}\text { Trace elements and } \\
\text { major and minor ions }\end{array}$} & \multicolumn{2}{|c|}{ Nutrients } & \multicolumn{2}{|c|}{$\begin{array}{l}\text { Uranium and other } \\
\text { radioactive constituents }\end{array}$} & & \\
\hline & Analyzed & Detected & Analyzed & Detected & Analyzed & Detected & Analyzed & Detected \\
\hline Regulatory, health-based & 14 & 14 & 2 & 2 & 5 & 5 & 21 & 21 \\
\hline None & 10 & 10 & 3 & 3 & 2 & 2 & 15 & 15 \\
\hline Total: & 36 & 36 & 6 & 6 & 7 & 7 & 49 & 49 \\
\hline
\end{tabular}

\begin{tabular}{|c|c|c|}
\hline \multirow{3}{*}{ Benchmark type } & \multicolumn{2}{|c|}{ Groups of orga } \\
\hline & \multicolumn{2}{|c|}{$\begin{array}{l}\text { Volatile organic } \\
\text { compounds }\end{array}$} \\
\hline & Analyzed & Detected \\
\hline Regulatory, health-based & 33 & 7 \\
\hline Nonregulatory, health-based & 26 & 1 \\
\hline Nonregulatory, aesthetic-based & 0 & 0 \\
\hline None & 26 & 0 \\
\hline Total: & 85 & 8 \\
\hline \multirow{4}{*}{ Benchmark type } & \multicolumn{2}{|r|}{ Other cons } \\
\hline & \multicolumn{2}{|c|}{$\begin{array}{l}\text { Geochemical and } \\
\text { age-dating tracers }\end{array}$} \\
\hline & \multicolumn{2}{|r|}{ Number of } \\
\hline & Analyzed & Detected \\
\hline Regulatory, health-based & 1 & 1 \\
\hline Nonregulatory, health-based & 0 & 0 \\
\hline Nonregulatory, aesthetic-based & 1 & 1 \\
\hline None & 14 & 14 \\
\hline Total: & 16 & 16 \\
\hline \multirow{3}{*}{ Benchmark type } & \multicolumn{2}{|c|}{ Sum of all constituents } \\
\hline & \multicolumn{2}{|c|}{ Number of constituents } \\
\hline & Analyzed & Detected \\
\hline Regulatory, health-based & 62 & 32 \\
\hline Nonregulatory, health-based & 49 & 6 \\
\hline Nonregulatory, aesthetic-based & 9 & 9 \\
\hline None & 114 & 30 \\
\hline Total: & 234 & 77 \\
\hline
\end{tabular}


and a subset of these constituents was selected for additional evaluation (table 3) on the basis of the following two criteria:

- Constituents present at high or moderate relativeconcentrations at the USGS-GAMA grid sites or in the CDPH water-quality database for any sample collected between June 1, 2006, and June 1, 2009;

- Organic constituents with detection frequencies of greater than 10 percent in the USGS-GAMA grid site dataset for the study unit.

The USGS conducted a review of the CDPH waterquality database (January 1, 1976, to May 31, 2006) to identify constituents with high relative-concentrations historically, but not currently. Constituent concentrations may be historically high, but not currently high, because of improvement of groundwater quality with time or abandonment of sites with high concentrations. Historically high concentrations of constituents that did not otherwise meet the criteria for additional evaluation in the status assessment are not considered representative of potential groundwaterquality concerns in the study unit from 2006 to 2009.

For the NOCO study unit, nine constituents had high relative-concentrations reported in the CDPH database during the historical period, but did not also have high concentrations reported during the current period or in the USGS-GAMA dataset (table 4).

Table 3. Constituents selected for additional evaluation in the status assessment, Northern Coast Ranges study unit, 2009, California GAMA Priority Basin Project.

[Benchmark type: Regulatory, health-based benchmarks: MCL-US, USEPA maximum contaminant level; MCL-CA, CDPH maximum contaminant level. Nonregulatory, health-based benchmarks: NL-CA, CDPH notification level. Nonregulatory, aesthetic-based benchmarks: SMCL-CA, CDPH secondary maximum contaminant level. Benchmark units: $\mu \mathrm{g} / \mathrm{L}$, micrograms per liter; $\mathrm{mg} / \mathrm{L}$, milligrams per liter. Abbreviations: USGS, U.S. Geological Survey; GAMA, Groundwater Ambient Monitoring and Assessment Program; USEPA, U.S. Environmental Protection Agency; CDPH, California Department of Public Health; TDS, total dissolved solids; MTBE, methyl tert-butyl ether]

\begin{tabular}{|c|c|c|c|c|c|c|}
\hline \multirow{2}{*}{ Constituent class } & \multirow{2}{*}{ Typical use or source } & \multicolumn{3}{|c|}{ Benchmark } & \multirow{2}{*}{$\begin{array}{l}\text { Criteria for } \\
\text { selection } \\
\text { for status } \\
\text { assessment }\end{array}$} & \multirow{2}{*}{$\begin{array}{l}\text { Selected for } \\
\text { understanding } \\
\text { assessment }\end{array}$} \\
\hline & & Type $^{1}$ & Value & Units & & \\
\hline \multicolumn{7}{|c|}{ Inorganic constituents with health-based benchmarks } \\
\hline \multicolumn{7}{|l|}{ Trace elements } \\
\hline Arsenic & Naturally occuring & MCL-US & 10 & $\mu \mathrm{g} / \mathrm{L}$ & Concentration & Yes \\
\hline Nickel & Naturally occuring & MCL-CA & 100 & $\mu \mathrm{g} / \mathrm{L}$ & Concentration & No \\
\hline \multicolumn{7}{|l|}{ Nutrients } \\
\hline Nitrate (as nitrogen) & $\begin{array}{c}\text { Fertilizer, human and animal } \\
\text { waste, naturally occuring }\end{array}$ & MCL-US & 10 & $\mathrm{mg} / \mathrm{L}$ & Concentration & No \\
\hline \multicolumn{7}{|c|}{ Inorganic constituents with aesthetic-based benchmarks } \\
\hline \multicolumn{7}{|c|}{ Organic constituents with health-based benchmarks } \\
\hline \multicolumn{7}{|l|}{ Volatile organic compounds } \\
\hline Chloroform (Trichloromethane) & $\begin{array}{l}\text { Disinfection byproduct, } \\
\text { trihalomethane }\end{array}$ & MCL-US & ${ }^{2} 80$ & $\mu \mathrm{g} / \mathrm{L}$ & $\begin{array}{l}\text { Concentration, } \\
\text { frequency }\end{array}$ & Yes \\
\hline Vinyl chloride (Chloroethene) & Organic synthesis reagent & MCL-CA & 0.5 & $\mu \mathrm{g} / \mathrm{L}$ & Concentration & No \\
\hline MTBE & Gasoline oxygenate & MCL-CA & 13 & $\mu \mathrm{g} / \mathrm{L}$ & Concentration $^{3}$ & No \\
\hline \multicolumn{7}{|l|}{ Pesticides and pesticide degradates } \\
\hline Simazine & Herbicide & MCL-US & 4 & $\mu \mathrm{g} / \mathrm{L}$ & Frequency & Yes \\
\hline \multicolumn{7}{|c|}{ Special-interest constituent with health-based benchmark } \\
\hline Perchlorate & $\begin{array}{l}\text { Naturally occuring, rocket fuel, } \\
\text { fireworks, fertilizer }\end{array}$ & MCL-CA & 6 & $\mu \mathrm{g} / \mathrm{L}$ & $\begin{array}{c}\text { Concentration, } \\
\text { frequency }\end{array}$ & Yes \\
\hline
\end{tabular}

${ }^{1}$ Maximum contaminant level benchmarks are listed as MCL-US when the MCL-US and MCL-CA are identical and as MCL-CA when the MCL-CA is lower than the MCL-US or no MCL-US exists. Sources of benchmarks:

MCL-CA, NL-CA, and SMCL-CA: California Department of Public Health $(2006,2008,2010)$

MCL-US: U.S. Environmental Protection Agency (2008, 2009a, 2009b, 2012).

${ }^{2}$ Benchmark value is the sum of four trihalomethanes (chloroform, bromodichloromethane, dibromochloromethane, and bromoform).

${ }^{3}$ High values were found in the CDPH database during the current period of study. MTBE was detected only at low relative-concentrations by USGS-GAMA. 
Table 4. Constituents reported at concentrations greater than benchmarks historically (January 1, 1976 to May 31, 2006) in the California Department of Public Health database, but not during the 3-year time period used in the status assessment, Northern Coast Ranges study unit, California GAMA Priority Basin Project.

[Benchmark type: Regulatory, health-based benchmarks: MCL-US, USEPA maximum contaminant level; AL-US, USEPA action level; RSD5-US, USEPA risk-specific dose at a risk factor of $10^{-5}$; MCL-CA, CDPH maximum contaminant level. Nonregulatory, aesthetic-based benchmark: SMCL-CA, CDPH secondary maximum contaminant level. Benchmark units: $\mu \mathrm{g} / \mathrm{L}$, micrograms per liter; mg/L, milligrams per liter. Abbreviations: USGS, U.S. Geological Survey; GAMA, Groundwater Ambient Monitoring and Assessment Program; USEPA, U.S. Environmental Protection Agency; CDPH, California Department of Public Health; TTHM, total trihalomethanes]

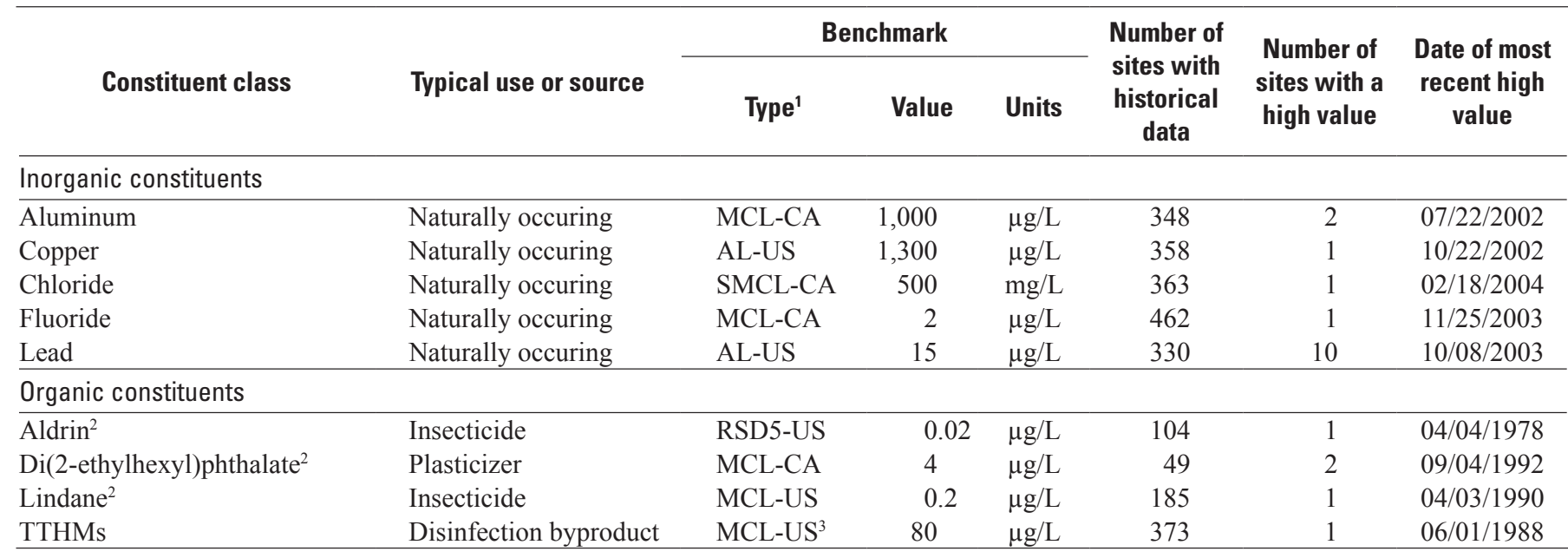

${ }^{1}$ Maximum contaminant level benchmarks are listed as MCL-US when the MCL-US and MCL-CA are identical and as MCL-CA when the MCL-CA is lower than the MCL-US or no MCL-US exists. Sources of benchmarks: MCL-CA and SMCL-CA: California Department of Public Health (2006, 2008, 2010)

MCL-US, AL-US, and RSD5-US: U.S. Environmental Protection Agency (2008, 2009a, 2009b, 2012).

${ }^{2}$ Constituent not analyzed by USGS-GAMA in the Northern Coast Ranges study unit.

${ }^{3}$ MCL-US benchmark for TTHMs is for the sum of chloroform, bromodichloromethane, dibromochloromethane, and bromoform.

\section{Calculation of Aquifer-Scale Proportions}

The status assessment is intended to characterize the quality of groundwater resources in the primary aquifer system of the NOCO study unit. The primary aquifer system is defined by the depth intervals over which wells listed in the $\mathrm{CDPH}$ database are screened or perforated; these wells are primarily classified as municipal and community drinkingwater supply wells. The use of the term "primary aquifer system" does not imply that a discrete aquifer unit exists. In most groundwater basins, municipal and community supply wells generally are perforated at greater depths than domestic wells. However, to the extent that domestic wells are perforated over the same depth intervals as the CDPH wells, the assessments presented in this report also may be applicable to the portions of the aquifer system used for domestic drinking-water supplies.

Two statistical approaches, grid-based and spatially weighted (Belitz and others, 2010), were selected to evaluate the proportions of the primary aquifer system in the NOCO study unit with high, moderate, and low relativeconcentrations of constituents relative to benchmarks. Aquiferscale proportions are defined as the percentage of the area (rather than the volume) of the primary aquifer systems with high, moderate, and low relative-concentrations. For ease of discussion, these proportions are referred to as "high," "moderate," and "low" aquifer-scale proportions. Calculations of aquifer-scale proportions were made for individual constituents, as well as for classes of constituents. The classes consisted of groups of related individual constituents. For constituents with human-health benchmarks, the classes included trace elements, nutrients, radioactive constituents, volatile organic compounds, and pesticides.

Both statistical approaches use equal-area grids. The grid-cell sizes in the two study areas of the NOCO study unit were not the same; therefore, aquifer-scale proportions were calculated separately for the two study areas and then combined on an area-weighted basis to obtain aquifer-scale proportions for the study unit as a whole (Bennett and others, 2010; Fram and Belitz, 2012):

$$
P_{S U}=\sum P_{S A} F_{S A},
$$

where:

$$
\begin{aligned}
& P_{S U} \quad \begin{array}{l}
\text { is the aquifer-scale proportion for the } \\
\text { study unit, }
\end{array} \\
& P_{S A} \quad \begin{array}{l}
\text { is the aquifer-scale proportion for a study } \\
\text { area, and }
\end{array} \\
& F_{S A} \quad \begin{array}{l}
\text { is the fraction of the total study unit area } \\
\text { occupied by the study area. }
\end{array}
\end{aligned}
$$


Aquifer-scale proportions for individual constituents and constituent classes in the NOCO-CO and NOCO-IN study areas are presented in appendix $\mathrm{C}$ (tables $\mathrm{C} 1, \mathrm{C} 2$ ); results for the study unit as a whole are presented in the main body of the report.

The grid-based calculation uses the USGS-GAMA grid-well dataset. For each constituent, the high aquiferscale proportion was calculated by dividing the number of cells represented by a high relative-concentration for that constituent by the total number of grid cells with data for that constituent. The moderate and low aquifer-scale proportions were calculated similarly. Confidence intervals for the high aquifer-scale proportions for individual constituents were computed using the Jeffrey's interval for the binomial distribution (Brown and others, 2001; Belitz and others, 2010). For calculation of high aquifer-scale proportion for a class of constituents, cells were considered high if relativeconcentrations for any of the constituents in that class were high. Cells were considered moderate if values for any of the constituents were moderate, but no values were high. The grid-based estimate is spatially unbiased. However, the gridbased approach may not detect constituents that are present at high concentrations in small proportions of the primary aquifer systems.

The spatially weighted calculation uses the dataset assembled from the USGS-GAMA grid sites and data compiled in the CDPH database for samples collected between June 1, 2006, and June 1, 2009 (the most recent analysis was used for each constituent at each well). For each constituent, the high aquifer-scale proportion was calculated by computing the proportion of sites with high relative-concentrations in each cell and then averaging the proportions for all cells (Isaaks and Srivastava, 1989; Belitz and others, 2010). The moderate aquifer-scale proportion was calculated similarly. Confidence intervals for spatially weighted detection frequencies of high concentrations are not described in this report. For calculation of high aquifer-scale proportion for a class of constituents, the aquifer-scale proportions for sites were considered high if the relative-concentrations for any of the constituents in that class were high. Aquifer-scale proportions for sites were considered moderate if the relativeconcentrations for any of the constituents were moderate, but none were high.

In addition, for each constituent, the raw detection frequencies of high and moderate values for individual constituents were calculated using the same dataset as used for the spatially weighted calculations. Raw detection frequencies are not spatially unbiased, however, because the sites in the CDPH database are not uniformly distributed throughout the NOCO study unit (fig. 4). For example, if a constituent were present at high concentrations in a small region of the aquifer with a high density of sites, the raw detection frequency of high values would be greater than the high aquifer-scale proportion. Raw detection frequencies are provided for reference but were not used to assess aquiferscale proportions.
Aquifer-scale proportions discussed in this report were estimated primarily by using the grid-based approach and secondarily by using the spatially weighted approach. The grid-based aquifer-scale proportions were used unless the spatially weighted proportions were significantly different. Significantly different results were defined as follows:

- If the grid-based high aquifer-scale proportion was zero and the spatially weighted proportion was nonzero, then the spatially weighted result was used. This situation can happen when the relative-concentration of a constituent is high in a small fraction of the primary aquifer system.

- If the grid-based high aquifer-scale proportion was non-zero and the spatially weighted proportion was outside the 90 percent confidence interval, then the spatially weighted proportion was used.

The grid-based moderate and low proportions were used in most cases because the reporting levels for many organic constituents and some inorganic constituents in the $\mathrm{CDPH}$ database were higher than the threshold between moderate and low categories. However, if the grid-based moderate proportion was zero and the spatially weighted proportion non-zero, then the spatially weighted value was used as a minimum estimate for the moderate proportion.

\section{Understanding-Assessment Methods}

The understanding assessment is designed to evaluate natural and anthropogenic factors that may affect groundwater quality. A finite set of potential explanatory factors was considered: study area, land use, well depth, depth to the top of well casing perforation (top of perforation), density of septic tanks, density of leaking (or formerly leaking) underground fuel tanks (LUFTs), aridity index, groundwater age, oxidationreduction condition (redox), field water temperature, distance to nearest hot spring listed in the USGS Mineral Resources Data System (MRDS), distance to nearest geothermal well listed in the California Department of Conservation Division of Oil, Gas, and Geothermal Resources (DOGGR) database, dissolved oxygen concentration, and $\mathrm{pH}$. Statistical tests were used to identify significant correlations between the constituents of interest and these potential explanatory factors.

A subset of the constituents examined in the status assessment and selected classes of constituents were examined in the understanding assessment:

- Constituents with high aquifer-scale proportions of greater than 2 percent. These constituents were selected to focus the understanding assessment on those constituents that may have the greatest effect on groundwater quality.

- Classes of organic constituents and special-interest constituents detected in 10 percent or more of the USGS-GAMA grid sites, regardless of concentration. 
The understanding assessment was based on the 58 grid sites sampled by USGS-GAMA. CDPH sites were not used because data for many of the potential explanatory factors were not available. In particular, data for age-dating tracers, dissolved oxygen, well depth, and depth to the top of screened interval are not maintained in the CDPH database.

\section{Statistical Analysis}

Nonparametric statistical methods were used to test the significance of correlations among water-quality variables and potential explanatory variables. Nonparametric statistics are robust techniques that are generally not affected by outliers and do not require that the data follow any particular distribution (Helsel and Hirsch, 2002). The significance level (p) used for hypothesis testing for this report was compared to a threshold value $(\alpha)$ of 5 percent $(\alpha=0.05)$ to evaluate whether the relation was statistically significant $(p<\alpha)$.

Two different statistical tests were used because the set of potential explanatory factors included categorical and continuous variables. Correlations among continuous variables (land use, septic tank density, LUFT density, well depth, depth to top-of-perforations, dissolved oxygen concentration, $\mathrm{pH}$, field water temperature, aridity index, and distance to the nearest hot spring listed in the USGS MRDS and geothermal well listed in the DOGGR database) were investigated by using Spearman's method to calculate the rank-order correlation coefficients $(\rho)$ among continuous variables. The values of $\rho$ can range from +1.0 (perfect positive correlation), through 0.0 (no correlation), to -1.0 (perfect negative correlation). For potential explanatory factors that were classified into categories (study area, groundwater age, geochemical conditions, and well depth class), the values of water-quality parameters between the categories were compared by using the Wilcoxon rank-sum test. The Wilcoxon rank-sum test is a median test statistic that compares two independent data groups (categories) to determine whether one group contains larger values than the other (Helsel and Hirsch, 2002). The null hypothesis for the Wilcoxon ranksum test is that there is no significant difference between the observations of the two independent data groups being tested. All statistical analyses were done using TIBCO Spotfire $\mathrm{S}+{ }^{\circledR}$ 8.1 for Windows (TIBCO Software Inc., 2008).

\section{Potential Explanatory Factors}

Brief descriptions of potential explanatory factors (land use, well construction, hydrologic conditions, groundwater age, and geochemical conditions) are given in this section. Correlations among these potential explanatory factors that could affect apparent relations between potential explanatory factors and water quality also are described. The data sources and methods used for assigning values for potential explanatory factors are described in appendix B.

\section{Land Use}

Land use was quantified as the percentages of three land-use types: agricultural, urban, and natural. Land-use percentages were calculated for the study unit, the study areas, and within a radius of 500 meters (m) (500-m buffers) around sites (Johnson and Belitz, 2009).

In the NOCO study unit, natural lands are mostly grasslands, wetlands, beaches, and forests, and the primary use of agricultural land is for pasture (cattle, sheep, and poultry), row crops, hay, vineyards, and timberlands (Nakagaki and others, 2007). The largest urban areas are the cities of Crescent City, Arcata, Eureka, Fort Bragg, Willits, Ukiah, and Lakeport (fig. 5).

Land use based on all of the land within the NOCO study unit was 60 percent natural, 29 percent agricultural, and 11 percent urban (fig. 6A). Compared to the land use in the entire study unit, the average land use in $500-\mathrm{m}$ buffer areas around the $\mathrm{CDPH}$ sites was less natural (56 percent), less agricultural (19 percent), and more urban (25 percent). The average land use in the 500-m buffer areas around the USGS-GAMA grid sites was 46 percent natural, 37 percent agricultural, and 17 percent urban. The difference between overall land use in the NOCO study unit and land use around the CDPH sites and USGS-GAMA grid sites reflects the fact that CDPH sites and USGS-GAMA grid sites are preferentially located where people are living and working. The difference between the average land use around the CDPH sites and around the USGS-GAMA grid sites reflects the spatially distributed nature of the USGS-GAMA grid sites. The CDPH sites are more biased towards urban land use because more urban areas typically have a higher density of $\mathrm{CDPH}$ sites.

The 58 USGS-GAMA grid sites showed a wide variation in land use (fig. $6 B$ ). In the NOCO-IN study area, approximately two-thirds of the sites were primarily mixtures of agricultural and natural land use, and most of the other sites were primarily mixtures of urban and agricultural land use. In the NOCO-CO study area, approximately one-half of the sites were primarily mixtures of urban and natural land use, and most of the other sites were dominated by agricultural land use. The median amount of percent urban land use was significantly greater in the areas surrounding the NOCO-CO sites than for the NOCO-IN sites ( $p=0.022$; table B2).

Septic tanks and LUFTs within the 500-m buffers around the USGS-GAMA grid sites also were used as markers of land-use patterns. Generally, areas with greater percentages of urban land use have more septic tanks and LUFTs on average, and areas with natural land use have fewer septic tanks and LUFTs. The density of septic tanks the NOCO-IN study area ranged from 0.1 to 30.8 tanks per square kilometer (tanks $/ \mathrm{km}^{2}$ ), with a median of 4.8 tanks $/ \mathrm{km}^{2}$ (table B2). In the NOCO-CO study area, the density of septic tanks ranged from 0.4 to 44.9 tanks $/ \mathrm{km}^{2}$, with a median of $6.6 \operatorname{tanks} / \mathrm{km}^{2}$. There were no significant differences in the density of septic tanks $(\mathrm{p}=0.54)$ between the NOCO-IN and NOCO-CO study 

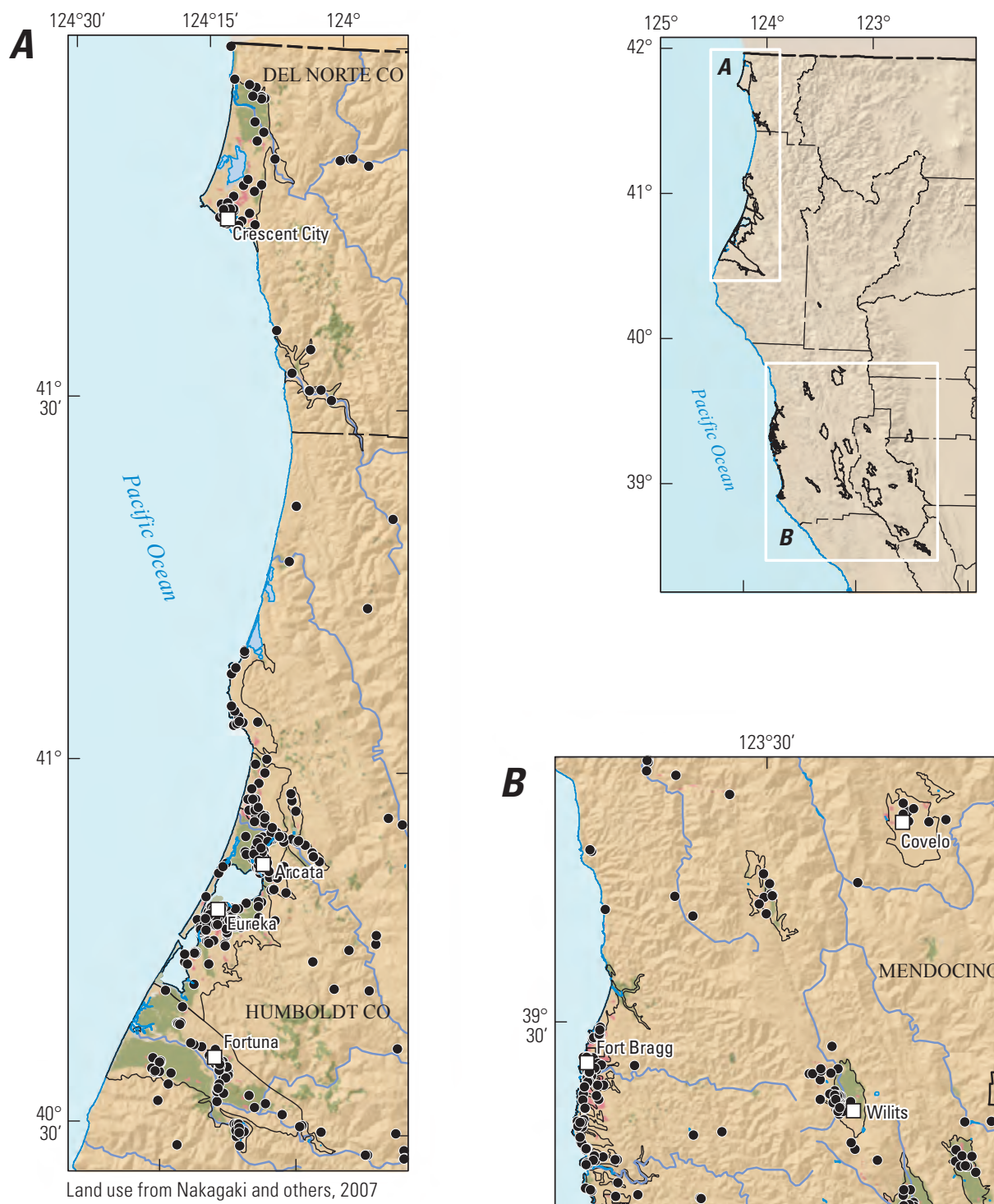

\section{EXPLANATION}

Land Use

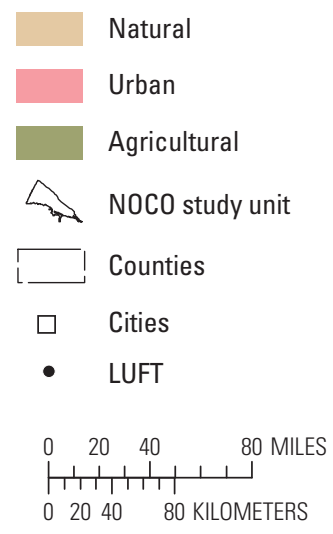

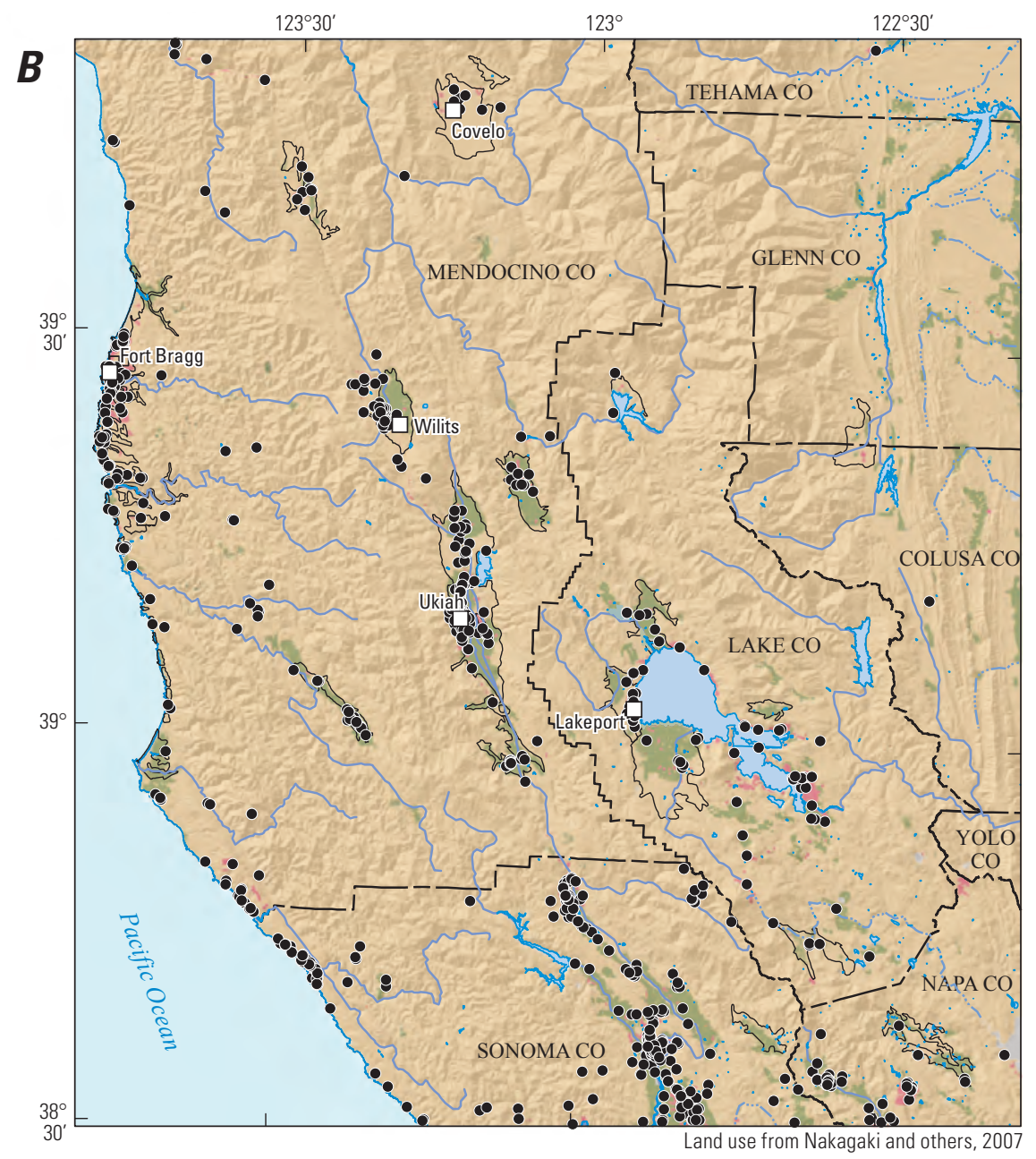

Figure 5. Land use and the location of leaking or formerly leaking underground fuel tanks (LUFTs) in the Northern Coast Ranges (NOCO) study unit, 2009, California GAMA Priority Basin Project. 


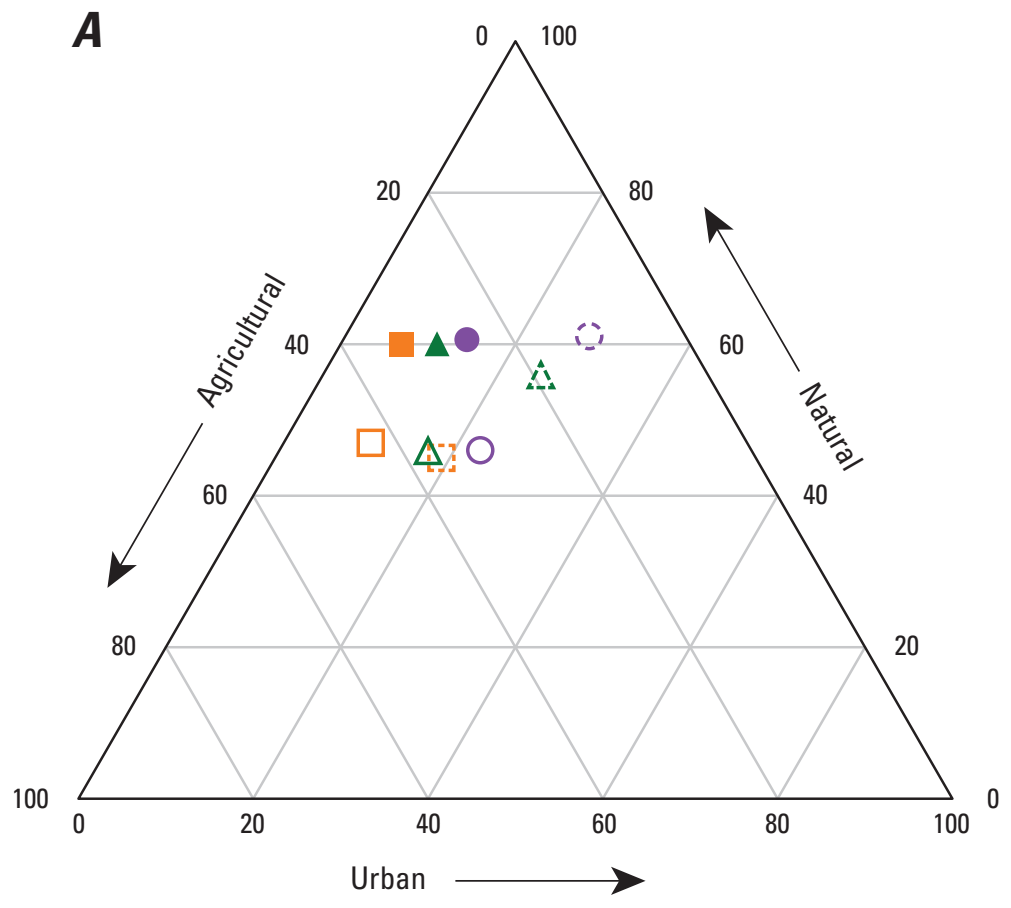

EXPLANATION

Average by individual study unit and study area

- NOCO study unit

- NOCO-IN study area

- NOCO-CO study area

Based on 500-meter buffer surrounding USGS-GAMA grid sites
$\triangle \quad$ NOCO study unit
$\square \quad$ NOCO-IN study area
NOCO-CO study area

Based on 500-meter buffer surrounding CDPH sites

怠 NOCO study unit

NOCO-IN study area

a) NOCO-CO study area

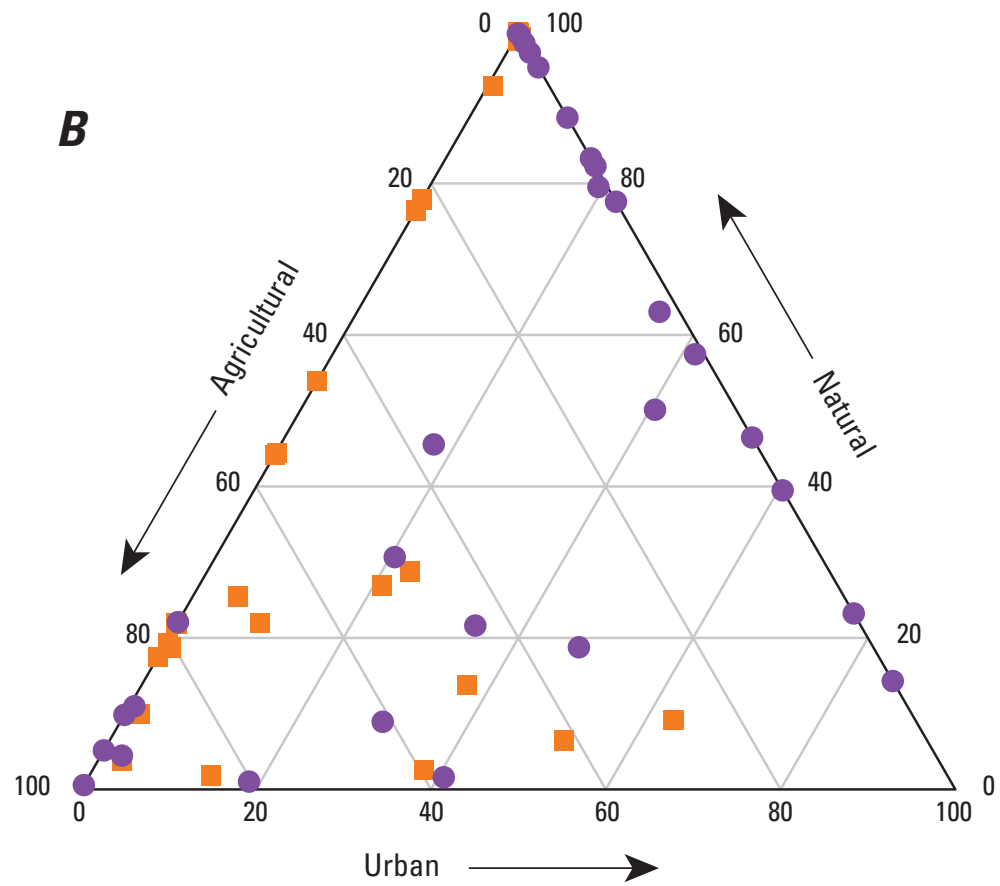

All wells by individual study area

- NOCO-IN study area

- NOCO-CO study area

Figure 6. Percentage of urban, agricultural, and natural land uses for the $(A)$ study unit and study areas and $(B)$ the area surrounding each USGS-GAMA grid site in the Northern Coast Ranges (NOCO) study unit, 2009, California GAMA Priority Basin Project. [NOCO-IN, Interior Basins study area; NOCO-CO, Coastal Basins study area] 
areas. The density of LUFTs was significantly greater in the areas surrounding the NOCO-CO sites than for the NOCO-IN sites $(\mathrm{p}=0.003)$. In the NOCO-IN study area, the density of LUFTs ranged from 0 to 1.77 tanks $/ \mathrm{km}^{2}$, with a median of 0.02 tanks $/ \mathrm{km}^{2}$. In the more urban NOCO-CO study area, the density of LUFTs ranged from 0.01 to 1.49 tanks $/ \mathrm{km}^{2}$, with a median of 0.160 tanks $/ \mathrm{km}^{2}$.

\section{Well Construction Information}

In the NOCO study unit, depths of the USGS-GAMA grid wells (not including the spring) ranged from 15 to $400 \mathrm{ft}$ below land surface (bls), with a median of $100 \mathrm{ft}$ bls (figs. 7A, $B$ ). Depths to the top-of-perforations ranged from 10 to $356 \mathrm{ft}$ bls, with a median of $40 \mathrm{ft}$ bls. The perforation length was as much as $237 \mathrm{ft}$ (median: $35 \mathrm{ft}$; table B3).

Well depths in the NOCO-IN study area ranged from 36 to $400 \mathrm{ft}$ bls, with a median of $116 \mathrm{ft}$ bls. Depths to top-ofperforations ranged from 15 to $148 \mathrm{ft}$ bls, with a median of $40 \mathrm{ft}$ bls and perforation lengths as much as $237 \mathrm{ft}$ (median: $60 \mathrm{ft}$ ). In the NOCO-CO study area, wells were shallower and had shorter perforation lengths than the wells in the NOCO-IN study area. Well depths ranged from 15 to $400 \mathrm{ft}$ bls, with a median of $85 \mathrm{ft}$ bls. Depths to top-of-perforations ranged from 10 to $356 \mathrm{ft}$ bls, with a median of $35 \mathrm{ft}$ bls and perforation lengths up to $120 \mathrm{ft}$ (median: $20 \mathrm{ft}$; table B3).

\section{Hydrologic Conditions}

Hydrologic conditions are represented by aridity index, field water temperature, and distance to nearest hot spring listed in the USGS MRDS and geothermal well listed in the DOGGR database (appendix B). The aridity index was used as an indicator of climate and is the average annual precipitation (PRISM Group, Oregon State University, 2012) divided by average annual evapotranspiration (Flint and Flint, 2007). Higher values indicate wetter conditions: values $<0.05$ are defined as hyper-arid, $0.05-0.20$ as arid, $0.20-0.50$ as semiarid, $0.50-0.65$ as dry sub-humid, $0.65-1.00$ as humid, and $>1.00$ as wet. In the NOCO-IN study area, the aridity index ranged from 0.48 to 1.73 , with a median of 0.83 (table B3). The aridity index in the NOCO-CO study area ranged from 0.86 to 2.17 , with a median of 1.26 .

Field water temperature was used as a potential indicator of groundwater interacting with hydrothermal systems (Forrest and others, 2013). In the NOCO-IN study area, field water temperatures ranged from 12.5 to 25.0 degrees Celsius $\left({ }^{\circ} \mathrm{C}\right)$, with a median of $18.0^{\circ} \mathrm{C}$ (table B3). Field water temperatures in the NOCO-CO study area ranged from 10.5 to $18.0^{\circ} \mathrm{C}$, with a median of $13.0^{\circ} \mathrm{C}$.

Distance to the nearest hot spring listed in the USGS MRDS and geothermal well listed in the DOGGR database was also used as a potential indicator of groundwater interacting with hydrothermal systems (fig. 3C). Previous investigations in the Coast Range Mountains of northern California by the USGS and others have shown that water discharged from thermal/mineral springs are commonly enriched with dissolved trace elements such as boron, arsenic, bromide, lithium, silver, and gold, among other trace elements and major and minor ions (Berkstresser, 1968; Thompson and others, 1978; Goff and others, 1993; Peters, 1993). While being near a hot spring or geothermal well alone does not prove direct mixing with thermal spring waters, it may indicate a greater probability that groundwater at a site may be influenced to some degree by the underlying hydrothermal system supplying the hot spring or geothermal well. In the NOCO-IN study area, distance to the nearest hot spring listed in the USGS MRDS ranged from 0.61 to 30.9 kilometers $(\mathrm{km})$, with a median of $13.5 \mathrm{~km}$. Distance to the nearest geothermal well listed in the DOGGR database ranged from 0.37 to $93.7 \mathrm{~km}$, with a median of $26.5 \mathrm{~km}$. In the NOCO-CO study area, the distance to the nearest hot spring ranged from 20.2 to $142 \mathrm{~km}$, with a median of $103 \mathrm{~km}$, and the distance to the nearest geothermal well ranged from 51.1 to $341 \mathrm{~km}$, with a median of $223 \mathrm{~km}$ (table B3; U.S. Geological Survey, 2005; California Department of Conservation, 2013).

Hydrologic condition data indicate that the climate was drier, the field water temperatures were warmer, and the hot springs and geothermal wells were closer to the USGS-GAMA sites in the NOCO-IN study area (inland) compared to sites in the NOCO-CO study area (coastal) (tables 6, B3).

\section{Groundwater Age}

Data for the age-dating tracers tritium and carbon-14 were used to classify groundwater age distributions into three categories: modern, mixed, and pre-modern (appendix B). Groundwater with tritium activity $>0.5$ tritium unit (TU) was defined as "modern," and groundwater with tritium activity $<0.5$ TU was defined as "pre-modern." Modern groundwater contains a substantial component of water recharged since 1952 (Michel, 1989). The presence of premodern groundwater also was identified using the carbon-14 data: samples with percentage of modern carbon $<88$ percent were considered to contain a substantial component of premodern groundwater. Samples with tritium activity $>0.5 \mathrm{TU}$ and modern carbon percentage $<88$ percent were classified as "mixed-age." Samples with tritium activity $>0.5$ TU but no carbon-14 data were classified as "modern or mixed-age." Of the 58 samples collected by USGS-GAMA, 24 were classified as modern, 20 were mixed-age (evidence of modern and pre-modern groundwater in the same sample), 13 were premodern, and 1 was modern or mixed-age (table B4).

Classified groundwater ages generally increased with well depth and depth to the top of the well perforations. Groundwater with pre-modern-age distributions came from wells with significantly greater depths to top of the perforation than groundwater with modern $(\mathrm{p}=<0.001)$ or mixed-age distributions $(\mathrm{p}=0.008)$ (figs. $8 B, C)$. Groundwater with modern-age distributions came from wells with significantly shallower depths than groundwater with mixed-age $(p=0.006)$ or pre-modern-age distributions $(\mathrm{p}=0)(\underline{\text { figs. } 8 \mathrm{~A}, \mathrm{C}})$. 

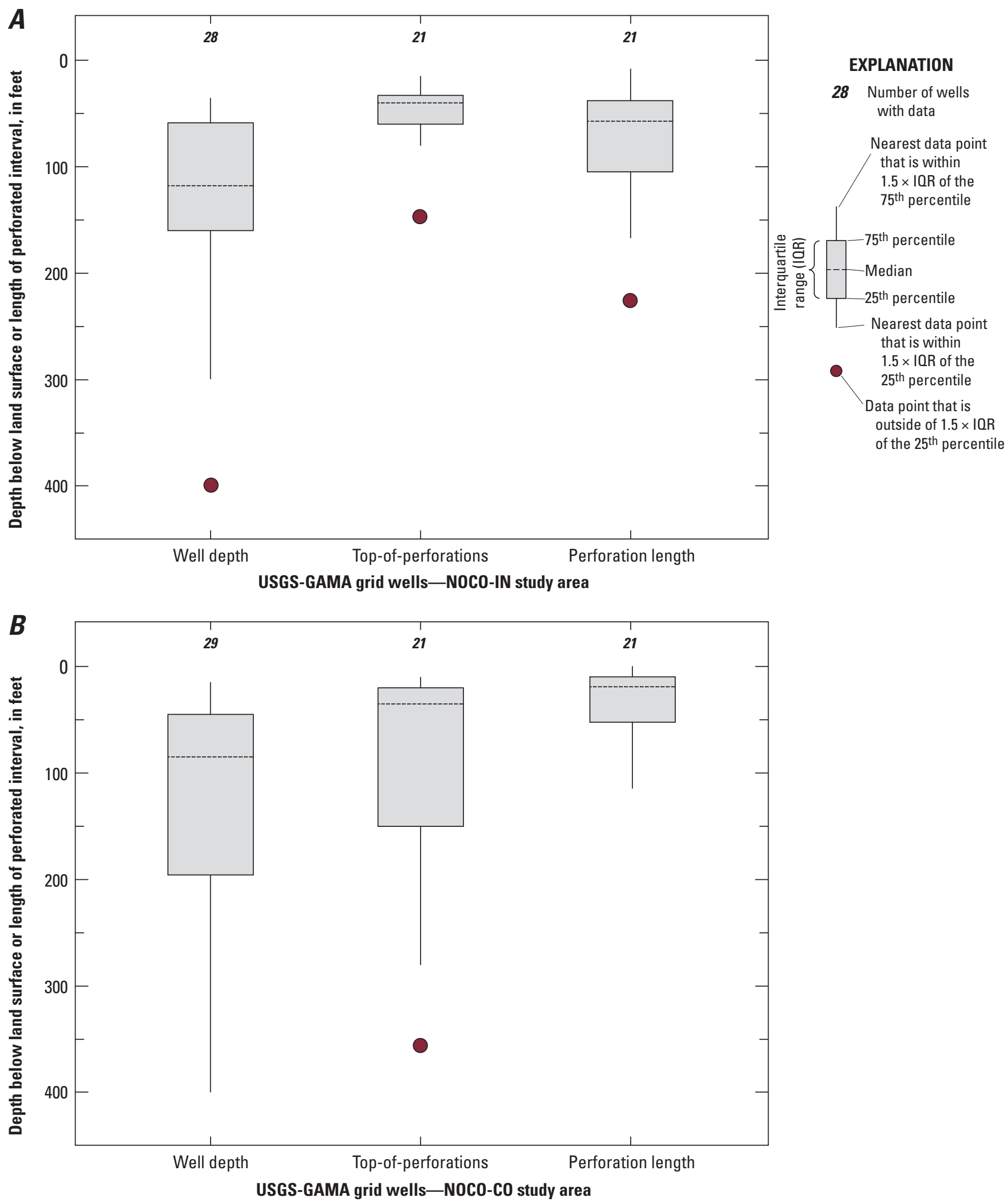

Figure 7. Construction characteristics for USGS-GAMA grid sites in the $(A)$ Interior Basins study area and $(B)$ Coastal Basins study area, Northern Coast Ranges study unit, 2009, California GAMA Priority Basin Project. 

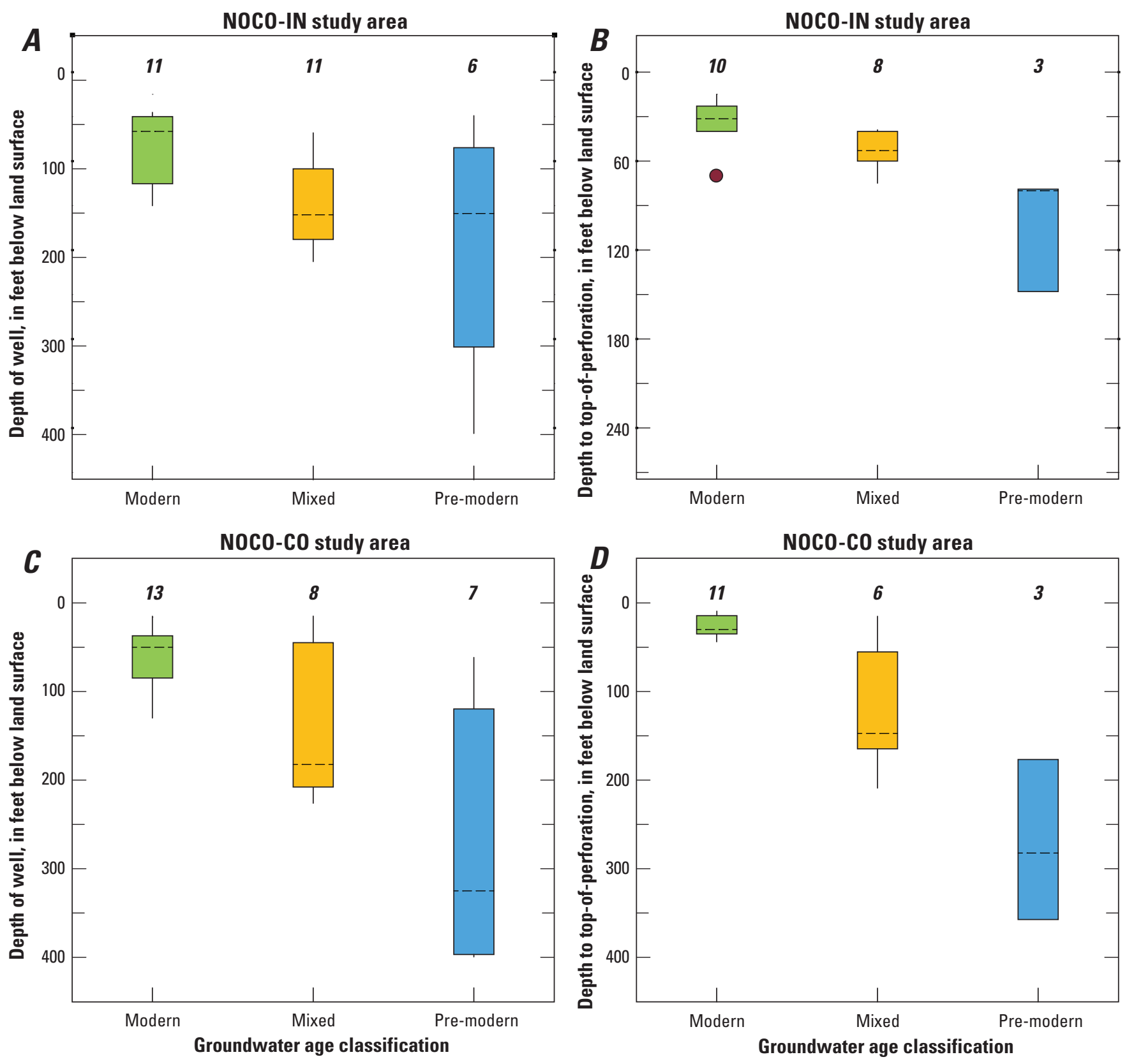

EXPLANATION

19 Number of wells with data

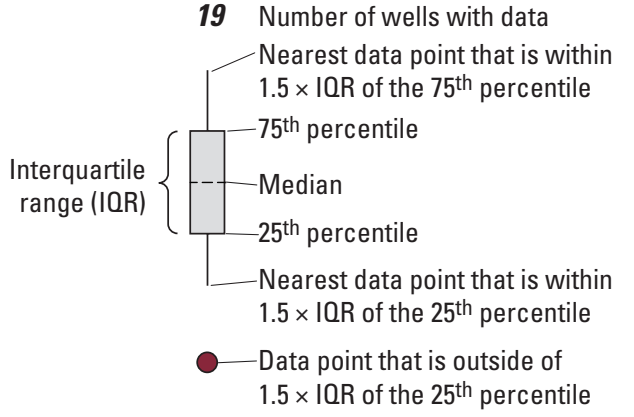

Figure 8. Relation of groundwater age classification to $(A)$ well depth and $(B)$ depth to top-of-perforations for wells in the Interior Basins study area, $(C)$ well depth and $(D)$ depth to top-of-perforations for wells in the Coastal Basins study area, and $(E)$ bar chart showing the depth class of all wells in the Northern Coast Ranges study unit, 2009, California GAMA Priority Basin Project. 


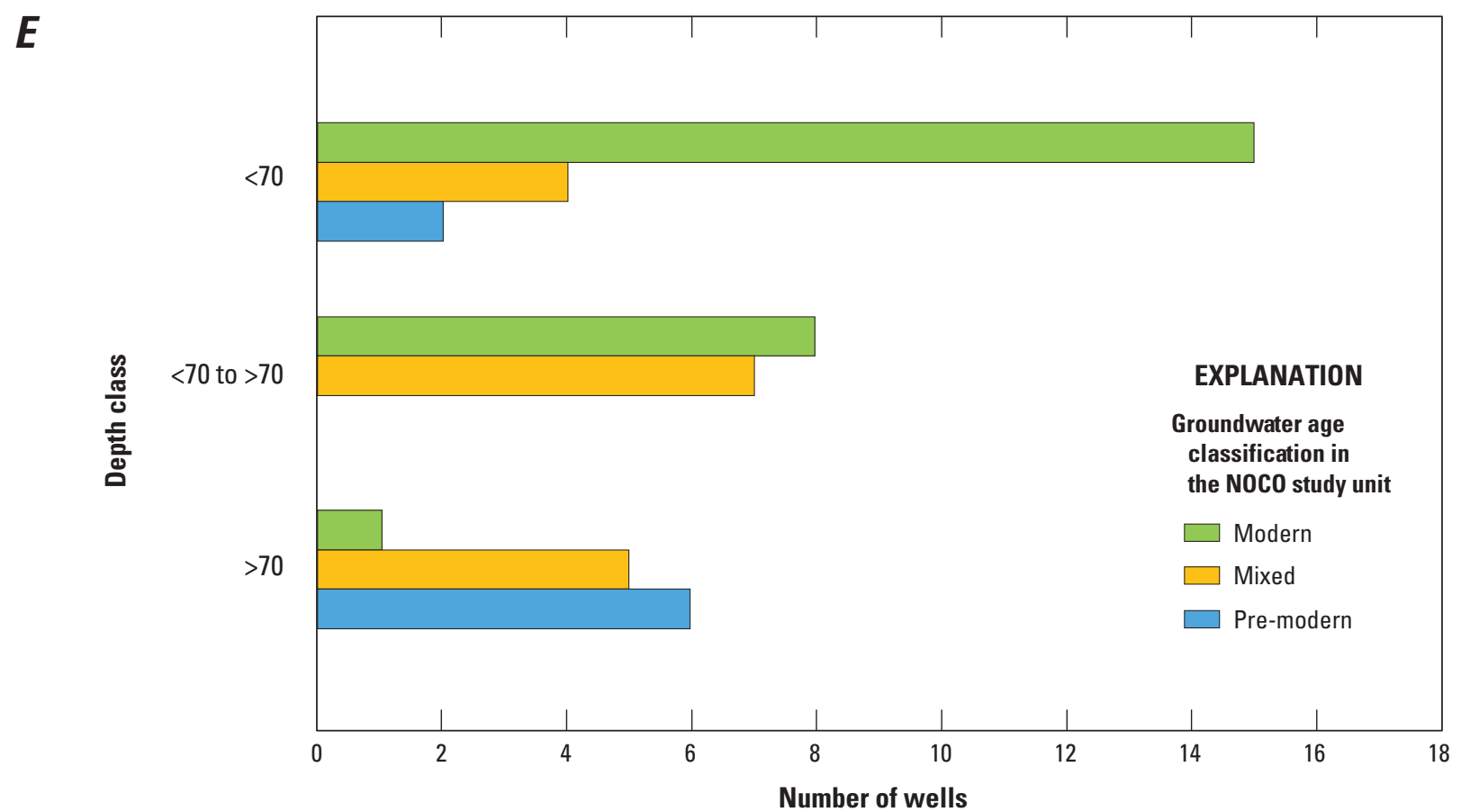

Figure 8. - Continued

Classified groundwater ages were used to create a classification system for well depth. Wells of depth less than a critical depth were defined as shallow; wells with perforations beginning above the critical depth and ending below the critical depth were defined as mixed-depth; wells with perforations entirely below the critical depth were defined as deep. Wells with total well depth below the critical depth and unknown perforation information were defined as mixed-depth or deep. The critical depth of $70 \mathrm{ft}$ bls (depth to top of the perforation interval) was selected by optimizing the segregation of modern-age groundwater into shallow wells, mixed-age groundwater into mixed-depth wells, and premodern-age groundwater into deep wells.

\section{Classification system for well depth}

[Abbreviations: $\mathrm{ft}$ bls, feet below land surface; $\geq$, greater than or equal to; $<$, less than]

\begin{tabular}{lcc}
\hline $\begin{array}{c}\text { Well depth } \\
\text { classification }\end{array}$ & Well depth & $\begin{array}{c}\text { Depth to top of } \\
\text { the perforation }\end{array}$ \\
\hline Shallow & $<70 \mathrm{ft} \mathrm{bls}$ & $<70 \mathrm{ft} \mathrm{bls}$ \\
Mixed-depth & $\geq 70 \mathrm{ft} \mathrm{bls}$ & $<70 \mathrm{ft} \mathrm{bls}$ \\
Deep & $\geq 70 \mathrm{ft} \mathrm{bls}$ & $\geq 70 \mathrm{ft} \mathrm{bls}$ \\
Mixed-depth or deep & $\geq 70 \mathrm{ft} \mathrm{bls}$ & Unknown \\
\hline
\end{tabular}

In the NOCO study unit, 57 percent of the shallow wells had modern-age groundwater, 41 percent of the mixed-depth wells had mixed-age groundwater, and 55 percent of the deep wells had pre-modern-age groundwater (fig. 8E; table B4).
Eight wells were classified as mixed-depth or deep; three had mixed-age groundwater, and five had pre-modern-age groundwater. The spring had mixed-age groundwater and is not represented in figure 8 .

\section{Geochemical Conditions}

Sufficient chemical data, including dissolved oxygen (DO) concentration, were available and used to classify groundwater oxidation-reduction (redox) conditions into three categories: oxic, mixed, and anoxic (appendix B). Groundwater was oxic at 31 of the sites, mixed at 1 of the sites, and anoxic at 26 of the sites. Anoxic conditions were further subdivided into suboxic; manganese-reducing; iron-reducing; manganese- and iron-reducing; nitrate- and manganese-reducing; and nitrate-, manganese-, and ironreducing conditions (table B5).

\section{Correlations Between Explanatory Factors}

Apparent correlations between potential explanatory factors and water-quality constituents could result from correlations among potential explanatory factors; therefore, identification of statistically significant correlations between potential explanatory factors is important (tables 5,6). Implications of correlations between explanatory variables are discussed later in the report as part of analysis of factors affecting individual water-quality constituents. 
Table 5. Results of non-parametric (Spearman's rho method) analysis of correlations between selected potential explanatory factors, Northern Coast Ranges study unit, 2009, California GAMA Priority Basin Project.

[Explanation: Spearman's rho test used and rho values shown. Significance level ( $\mathrm{p} \leq 0.05)$; Correlations with $r h o>0.2$ and (or) $\mathrm{p}$-values $\leq 0.05$ are shown in bold. Abbreviations: GAMA, Groundwater Ambient Monitoring and Assessment Program; USGS, U.S. Geological Survey; $\leq$, less than or equal to; >, greater than; ns, no significant correlation; black text, significant positive correlation; red text, significant negative correlation; DOGGR, Division of Oil, Gas, and Geothermal Resources (California Department of Conservation)]

\begin{tabular}{|c|c|c|c|c|c|c|c|c|c|c|c|c|c|}
\hline $\begin{array}{l}\text { rho: Spearman's } \\
\text { correlation statistic }\end{array}$ & $\begin{array}{l}\text { Percent } \\
\text { urban } \\
\text { land use }\end{array}$ & $\begin{array}{l}\text { Percent } \\
\text { agricultural } \\
\text { land use }\end{array}$ & $\begin{array}{c}\text { Percent } \\
\text { natural } \\
\text { land use }\end{array}$ & $\begin{array}{l}\text { Density of } \\
\text { septic } \\
\text { tanks }\end{array}$ & $\begin{array}{l}\text { Density of } \\
\text { leaking } \\
\text { underground } \\
\text { fuel tanks }\end{array}$ & $\begin{array}{l}\text { Well } \\
\text { depth }\end{array}$ & $\begin{array}{c}\text { Depth } \\
\text { to top of } \\
\text { perforations }\end{array}$ & $\begin{array}{c}\text { Dissolved } \\
\text { oxygen } \\
\text { concentration }\end{array}$ & pH & $\begin{array}{l}\text { Field water } \\
\text { temperature }\end{array}$ & $\begin{array}{l}\text { Aridity } \\
\text { index }\end{array}$ & $\begin{array}{c}\text { Distance to } \\
\text { nearest hot } \\
\text { spring listed } \\
\text { in the USGS } \\
\text { Mineral } \\
\text { Resources } \\
\text { Data System }\end{array}$ & $\begin{array}{l}\text { Distance } \\
\text { to nearest } \\
\text { geothermal } \\
\text { well listed in } \\
\text { the DOGGR } \\
\text { database }\end{array}$ \\
\hline Percent urban land use & & ns & -0.36 & 0.50 & 0.51 & ns & ns & ns & ns & ns & $\mathbf{0 . 3 0}$ & 0.26 & 0.26 \\
\hline $\begin{array}{l}\text { Percent agricultural } \\
\text { land use }\end{array}$ & & & -0.80 & ns & ns & ns & ns & ns & ns & 0.39 & -0.29 & ns & -0.29 \\
\hline Percent natural land use & & & & -0.36 & -0.41 & ns & ns & $\mathrm{ns}$ & $\mathrm{ns}$ & ns & $\mathrm{ns}$ & $\mathrm{ns}$ & $\mathrm{ns}$ \\
\hline Density of septic tanks & & & & & 0.37 & ns & ns & ns & ns & ns & ns & ns & ns \\
\hline $\begin{array}{l}\text { Density of leaking } \\
\text { underground } \\
\text { fuel tanks }\end{array}$ & & & & & & ns & ns & ns & ns & ns & ns & 0.32 & ns \\
\hline Well depth & & & & & & & 0.82 & $\mathrm{~ns}$ & 0.56 & 0.34 & ns & $\mathrm{ns}$ & ns \\
\hline $\begin{array}{l}\text { Depth to top of } \\
\text { perforations }\end{array}$ & & & & & & & & ns & 0.68 & 0.39 & ns & ns & ns \\
\hline $\begin{array}{l}\text { Dissolved oxygen } \\
\text { concentration }\end{array}$ & & & & & & & & & ns & ns & ns & ns & ns \\
\hline $\mathrm{pH}$ & & & & & & & & & & ns & ns & ns & ns \\
\hline Field water temperature & & & & & & & & & & & -0.66 & -0.60 & -0.72 \\
\hline Aridity index ${ }^{1}$ & & & & & & & & & & & & 0.64 & 0.90 \\
\hline $\begin{array}{l}\text { Distance to nearest } \\
\text { hot spring listed in } \\
\text { the USGS Mineral } \\
\text { Resources Data } \\
\text { System }\end{array}$ & & & & & & & & & & & & & 0.79 \\
\hline $\begin{array}{l}\text { Distance to nearest } \\
\text { geothermal well } \\
\text { listed in the DOGGR } \\
\text { database }\end{array}$ & & & & & & & & & & & & & \\
\hline
\end{tabular}

${ }^{1}$ Aridity index is average annual precipitation (PRISM Group, Oregon State University, 2012) divided by average annual evapotranspiration (Flint and Flint, 2007). 
Table 6. Results of Wilcoxon rank-sum tests on USGS-GAMA grid site data used to determine significant differences between constituent values grouped by potential explanatory factors, Northern Coast Ranges study unit, 2009, California GAMA Priority Basin Project.

[Explanation: Potential explanatory factors without significant correlations are not shown on this table. Only results with p-values $\leq 0.05$ are considered significant in this study; Wilcoxon rank-sum tests with exact distribution and continuity correction; $Z$, test statistic for Wilcoxon test; a significantly positive $Z$ value in a column to the right indicates that the entry in the leftmost column has larger values in the first classification in the column to the right compared to the second classification; a significantly negative $\mathrm{Z}$ value in a column to the right indicates that the entry in the leftmost column has larger values in the second classification in the column to the right compared to the first classification. USGS-GAMA site identification numbers: NOCO-IN, Northern Coast Ranges study unit, Interior Basins study area; NOCO-CO, Northern Coast Ranges study unit, Coastal Basins study area. Abbreviations: USGS, U.S. Geological Survey; GAMA, Groundwater Ambient Monitoring and Assessment Program; $<$, less than; >, greater than; $\leq$, less than or equal to; ns, no significant difference (p-value > 0.05); DOGGR, Division of Oil, Gas, and Geothermal Resources (California Department of Conservation); \%, percent]

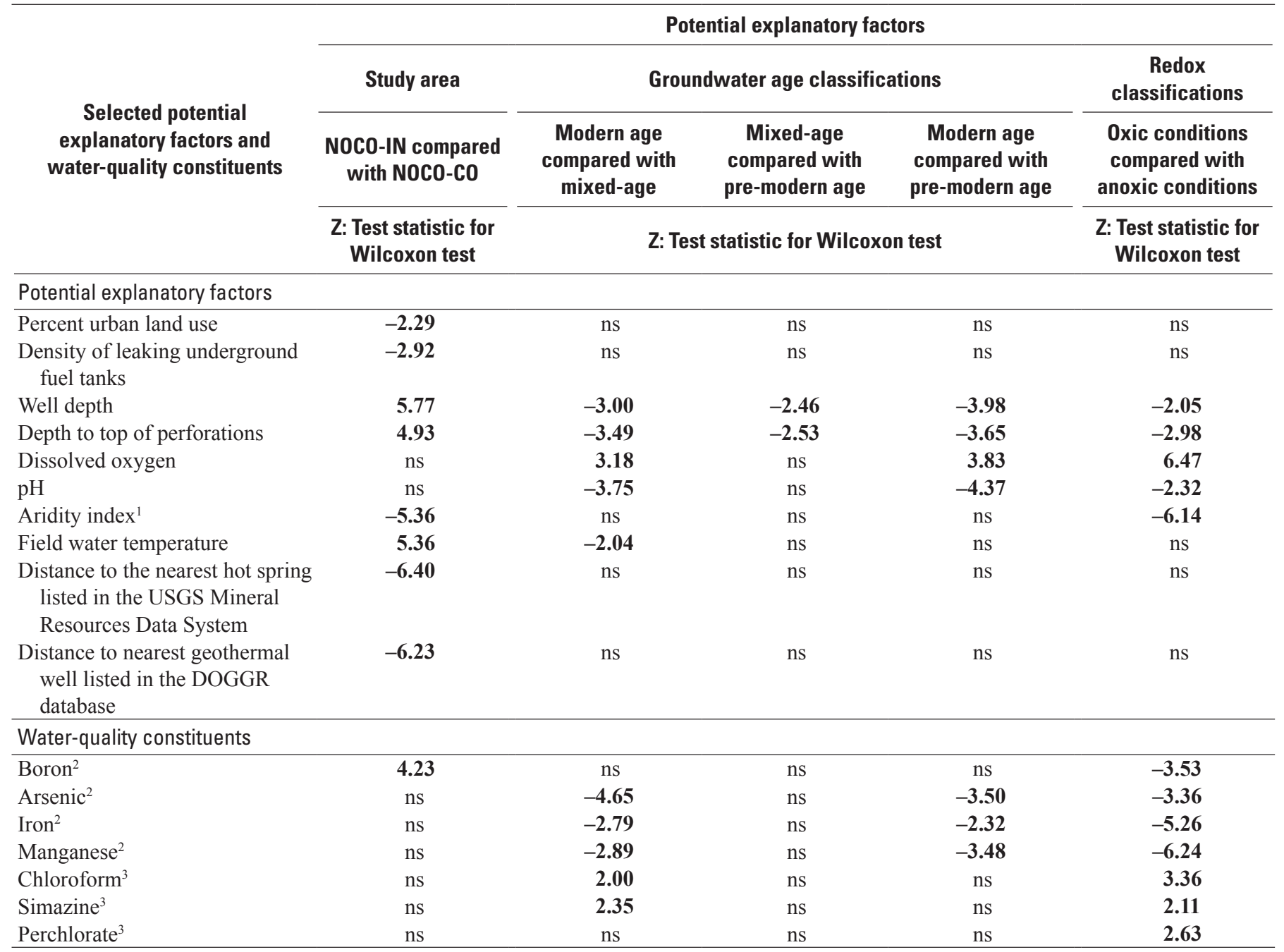

${ }^{1}$ Aridity index is average annual precipitation (PRISM Group, Oregon State University, 2012) divided by average annual evapotranspiration (Flint and Flint, 2007).

${ }^{2}$ Constituents with $\geq 2 \%$ high aquifer-scale proportion.

${ }^{3}$ Organic constituents (special-interest constituent) with detection frequencies $\geq 10 \%$, including detections below reporting levels. 
The NOCO-IN study area generally had deeper wells and deeper depth to top-of-perforations than the NOCO-CO study area. Samples from the NOCO-IN study area also had higher groundwater temperatures, and the climate was drier in the NOCO-IN study area as indicated by a lower aridity index (table 6). The NOCO-IN study area sites generally were located closer to hot springs or geothermal wells. The NOCO-CO study area had a higher percentage of urban land use and density of LUFTs than the NOCO-IN study area (table 6).

In the NOCO study unit, relations were observed between well depth and groundwater age. The median depth of wells with groundwater classified as pre-modern was deeper than the depths of wells with groundwater classified as modern or mixed-ages (table 6; figs. 8A, C). In addition, groundwater classified as mixed-age was deeper than groundwater classified as modern. The median depth to the top-of-perforations of wells with groundwater classified as pre-modern also was deeper than the depth to the top-of-perforations of wells with groundwater classified as modern or mixed-age (table 6; figs. $8 B, D$ ). Well depths or depths to top-of-perforations in wells with groundwater samples classified as modern and mixed-age were not significantly different.

Groundwater ages for most wells perforated entirely at depths $<70 \mathrm{ft}$ bls (15 of 19 wells, 79 percent) were modern age (figs. $8 B, D$ ). Groundwater ages for wells with the topof-perforations $<70 \mathrm{ft}$ but with the bottom-of-perforations $\geq 70 \mathrm{ft}$ were modern or mixed-age. Groundwater ages for most wells perforated entirely at depths $\geq 70 \mathrm{ft}$ were pre-modern or mixed-age.
The densities of septic tanks and LUFTs were positively correlated with percent urban land use and negatively correlated with natural land use (table 5).

Field water temperature was significantly positively correlated with well depth, depth to top-of-perforations, and the percentage of agricultural land use (table 5). Field water temperature was negatively correlated with the aridity index and distances to nearest hot spring and geothermal well. Groundwater temperatures also were significantly lower in sites with modern ages than in sites with mixed ages, indicating that groundwater temperatures generally increase with depth ( $\underline{\text { table } 6}$ ). The aridity index was positively correlated with distances to the nearest hot spring and geothermal well (table 5).

$\mathrm{pH}$ was positively correlated with well depth and depth to top-of-perforations (table 5), indicating increasing $\mathrm{pH}$ with increasing depth (fig. 9A). These correlations were expected based on previous studies in other aquifers in California (Jurgens and others, 2008) and reflect dissolution of primary aquifer minerals, causing the $\mathrm{pH}$ of groundwater to increase with depth and continued contact of groundwater with aquifer materials. $\mathrm{pH}$ values also were higher for groundwater with mixed or pre-modern ages and for groundwater with anoxic conditions (table 6; fig. 9A). DO concentrations were significantly greater in groundwater with modern or mixed ages than in groundwater with pre-modern ages (table 6; fig. $9 \mathrm{~B}$ ), indicating that DO has been consumed in older waters that have had more time to interact with oxidizable material in the groundwater flow system. 

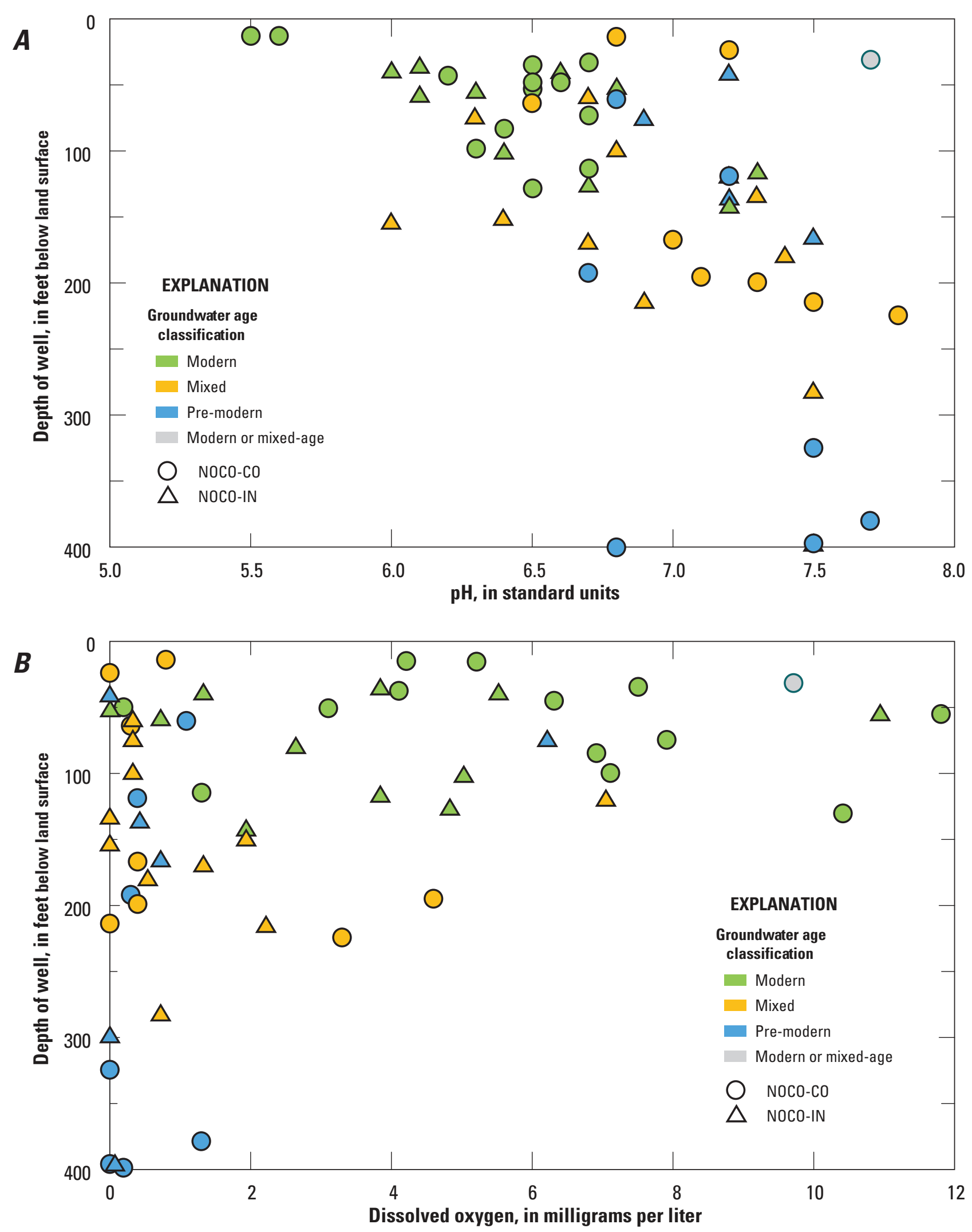

Figure 9. Groundwater age classification and well depth in relation to $(A) \mathrm{pH}$ and $(B)$ dissolved oxygen concentrations, Northern Coast Ranges study unit, 2009, California GAMA Priority Basin Project. [NOCO-IN, Interior Basins study area; NOCO-CO, Coastal Basins study area] 


\section{Status and Understanding of Water Quality}

The status assessment was designed to identify the constituents or classes of constituents most likely to be of water-quality concern because of their high relativeconcentrations or their prevalence. The assessment applies only to constituents having regulatory or nonregulatory health-based or aesthetic-based benchmarks established by the USEPA or the CDPH (California Department of Public Health, 2006, 2008, 2010; U.S. Environmental Protection Agency, 2008, 2009a, b, 2012). The spatially distributed, randomized approach to site selection and data analysis yields a view of groundwater quality in which all areas of the primary aquifer system are weighted equally; regions with a high density of groundwater use or with high density of potential contaminants were not preferentially sampled (Belitz and others, 2010).

The understanding assessment was designed to help answer the question of why selected constituents are, or are not, detected in the groundwater, and may improve understanding of how natural and anthropogenic factors affect groundwater quality. The assessment addresses a subset of the constituents selected for additional evaluation in the status assessment and is based on statistical correlations between water quality and a set of potential explanatory factors. The assessment was not designed to identify specific sources of specific constituents to specific sites.

The following discussion of the status and understanding assessment results is divided into two parts - inorganic constituents and organic constituents - and each part has a tiered structure. Each part begins with a survey of how many constituents were detected at any concentration in USGS-GAMA samples compared to the number analyzed and a graphical summary of the relative-concentrations of constituents detected in the grid sites. Aquifer-scale proportions are presented for the subset of constituents that met criteria for additional evaluation based on relativeconcentration, or for organic (special-interest) constituents, prevalence. For constituents that have understanding assessment results, those results are presented immediately following the status assessment results for that constituent.

The aquifer-scale proportions calculated by using the spatially weighted approach were within the 90 percent confidence intervals for their respective grid-based aquifer proportions for all 13 of the constituents listed in tables 7 , $\underline{\mathrm{C} 1}$, and $\underline{\mathrm{C} 2}$, providing evidence that the grid-based approach yields statistically equivalent results to the spatially weighted approach.

\section{Inorganic Constituents}

Inorganic constituents typically occur naturally in groundwater, although their concentrations may be influenced by human activities as well as by natural factors. All 49 inorganic constituents analyzed by USGS-GAMA were detected at least once in the NOCO study unit. Of these 49 constituents, 26 had regulatory or nonregulatory healthbased benchmarks, 8 had nonregulatory aesthetic-based benchmarks, and 15 had no established benchmarks (table 2).

Eight inorganic constituents were identified for additional evaluation in the status assessment because they were detected at moderate or high relative-concentrations in the USGS-GAMA grid sites. The constituents with health-based benchmarks are arsenic, barium, boron, nickel, and nitrate, and the constituents with aesthetic-based benchmarks are iron, manganese, and total dissolved solids (TDS) (figs. 10, 11; tables 3,7 ). Four of these inorganic constituents were selected for further evaluation in the understanding assessment because they were present at high relative-concentrations in $>2$ percent of the primary aquifer system: boron, arsenic, iron, and manganese.

\section{Inorganic Constituents with Health-Based Benchmarks}

Inorganic constituents with health-based benchmarks, as a group, had high relative-concentrations in 10.3 percent, moderate relative-concentrations in 13.8 percent, and low relative-concentrations (or non-detections) in 75.9 percent of the primary aquifer system (table $8 \mathrm{~A}$ ).

\section{Trace Elements}

Trace elements, as a class, were detected at high relative-concentrations (for one or more constituents) in 10.3 percent of the primary aquifer system, moderate relativeconcentrations in 8.6 percent, and low relative-concentrations in 81.1 percent (table 8A). Boron and arsenic were detected at high relative-concentrations in more than 2 percent of the primary aquifer system, and barium was detected at high relative-concentrations in 1.7 percent of the primary aquifer system (table 7). The spatial distributions of selected trace elements for USGS-GAMA grid sites and the CDPH sites are shown in figures 12 and 13. Note that boron was not sampled by the CDPH from June 1, 2006, to June 1, 2009. 
Table 7. Aquifer-scale proportions calculated using grid-based and spatially weighted methods for those constituents that met criteria for additional evaluation in the status assessment, Northern Coast Ranges study unit, 2009, California GAMA Priority Basin Project.

[Relative-concentration categories: high, concentration greater than water-quality benchmark; moderate, concentration is less than the benchmark and is greater than or equal to 0.1 of the benchmark (for organic and special-interest constituents) or 0.5 of the benchmark (for inorganic constituents); low, concentration less than 0.1 of benchmark (for organic constituents and special-interest constituents) or 0.5 of the benchmark (for inorganic constituents). Abbreviations: GAMA, Groundwater Ambient Monitoring and Assessment Program; CDPH, California Department of Public Health; TDS, total dissolved solids; MTBE, methyl tert-butyl ether; $\mu \mathrm{g} / \mathrm{L}$, micrograms per liter]

\begin{tabular}{|c|c|c|c|c|c|c|c|c|c|c|c|}
\hline \multirow{2}{*}{ Constituent } & \multicolumn{3}{|c|}{$\begin{array}{l}\text { Raw detection } \\
\text { frequency, } \\
\text { in percent }^{1}\end{array}$} & \multicolumn{3}{|c|}{$\begin{array}{l}\text { Spatially weighted } \\
\text { aquifer-scale proportion, } \\
\text { in percent }^{1}\end{array}$} & \multicolumn{3}{|c|}{$\begin{array}{l}\text { Grid-based } \\
\text { aquifer-scale proportion, } \\
\text { in percent }\end{array}$} & \multicolumn{2}{|c|}{$\begin{array}{l}90 \text { percent confidence } \\
\text { interval for grid-based } \\
\text { high proportion, } \\
\text { in percent }^{2}\end{array}$} \\
\hline & $\begin{array}{l}\text { Number } \\
\text { of sites }\end{array}$ & Moderate & High & $\begin{array}{l}\text { Number } \\
\text { of cells }\end{array}$ & $\begin{array}{l}\text { Moderate } \\
\text { aquifer } \\
\text { proportion }\end{array}$ & $\begin{array}{l}\text { High } \\
\text { aquifer } \\
\text { proportion }\end{array}$ & $\begin{array}{l}\text { Number } \\
\text { of sites }\end{array}$ & $\begin{array}{l}\text { Moderate } \\
\text { aquifer } \\
\text { proportion }\end{array}$ & $\begin{array}{c}\text { High aquifer } \\
\text { proportion }\end{array}$ & $\begin{array}{l}\text { Lower } \\
\text { limit }\end{array}$ & $\begin{array}{l}\text { Upper } \\
\text { limit }\end{array}$ \\
\hline \multicolumn{12}{|c|}{ Inorganic constituents with health-based benchmarks } \\
\hline \multicolumn{12}{|l|}{ Trace Elements } \\
\hline Arsenic & 130 & 3.1 & 3.1 & 58 & 6.0 & 3.5 & 58 & 6.9 & 3.4 & 1.0 & 9.2 \\
\hline Barium & 131 & 0 & 0.8 & 58 & 0 & 1.7 & 58 & 0 & 1.7 & 0.3 & 6.5 \\
\hline Boron $^{3}$ & 58 & 5.2 & 8.6 & 58 & 5.2 & 8.6 & 58 & 5.2 & 8.6 & 4.0 & 16.2 \\
\hline Nickel & 133 & 0.8 & 0 & 58 & 1.7 & 0 & 58 & 1.7 & 0 & 0 & 3.2 \\
\hline \multicolumn{12}{|l|}{ Nutrients } \\
\hline Nitrate & 220 & 1.8 & 0 & 58 & 1.4 & 0 & 57 & 3.5 & 0 & 0 & 3.3 \\
\hline \multicolumn{12}{|c|}{ Inorganic constituents with aesthetic-based benchmarks } \\
\hline Iron & 121 & 6.6 & 21.5 & 58 & 6.4 & 25.7 & 58 & 5.2 & 25.9 & 17.4 & 33.7 \\
\hline Manganese & 123 & 4.1 & 30.9 & 58 & 7.8 & 41.2 & 58 & 8.6 & 39.7 & 29.6 & 48.0 \\
\hline TDS & 118 & 5.1 & 0 & 58 & 6.9 & 0 & 58 & 6.9 & 0 & 0 & 3.2 \\
\hline \multicolumn{12}{|c|}{ Organic constituents with health-based benchmarks } \\
\hline \multicolumn{12}{|l|}{ Volatile organic compounds } \\
\hline Chloroform (Trichloromethane) & 118 & 1.7 & 0 & 58 & 2.2 & 0 & 58 & 1.7 & 0 & 0 & 3.2 \\
\hline Vinyl chloride (Chloroethene) & 115 & 0.9 & 0 & 58 & 1.7 & 0 & 58 & 1.7 & 0 & 0 & 3.2 \\
\hline $\mathrm{MTBE}^{4}$ & 134 & 0 & 0.7 & 58 & 0 & 0.2 & 58 & 0 & 0 & 0 & 3.2 \\
\hline \multicolumn{12}{|l|}{ Pesticides and pesticide degradates } \\
\hline Simazine & 123 & 0 & 0 & 58 & 0 & 0 & 58 & 0 & 0 & 0 & 3.2 \\
\hline \multicolumn{12}{|c|}{ Special-interest constituent with health-based benchmark } \\
\hline Perchlorate & 162 & 0.6 & 0 & 58 & 0.6 & 0 & 58 & 1.7 & 0 & 0 & 3.2 \\
\hline \multirow{3}{*}{\multicolumn{12}{|c|}{$\begin{array}{l}{ }^{1} \text { Based on most recent analyses for each CDPH site during June 1, 2006-June 1, 2009, combined with data from USGS-GAMA grid sites. } \\
{ }^{2} \text { Based on the Jeffrey's interval for the binomial distribution (Brown and others, 2001). }\end{array}$}} \\
\hline & & & & & & & & & & & \\
\hline \multicolumn{9}{|c|}{${ }^{3}$ Boron was not sampled by the CDPH during June 1, 2006-June 1, 2009.} & & & \\
\hline \multicolumn{12}{|c|}{$\begin{array}{l}{ }^{4} \mathrm{High} \text { relative-concentrations of MTBE were reported multiple times in the CDPH water-quality database from one site in the NOCO-IN study area during the current period of study. Sixteen groundwater } \\
\text { samples were collected by the CDPH between August } 16,2006 \text {, and May 20,2009, from this site for analysis of MTBE; } 15 \text { had concentrations of MTBE between } 13 \text { and } 21 \mu \mathrm{g} / \mathrm{L}(\mathrm{MCL}-\mathrm{CA}=13 \mu \mathrm{g} / \mathrm{L}) \text {, and } \\
1 \text { was a non-detection (most recent value, May } 20,2009) \text {. On that basis, it was determined that the non-detection of MTBE reported as the most recent value in the CDPH water-quality database does not } \\
\text { represent present-day conditions. The MTBE sample collected on April 30, } 2009(17 \mu \mathrm{g} / \mathrm{L}) \text { was substituted in order to more accurately reflect present-day conditions. }\end{array}$} \\
\hline
\end{tabular}




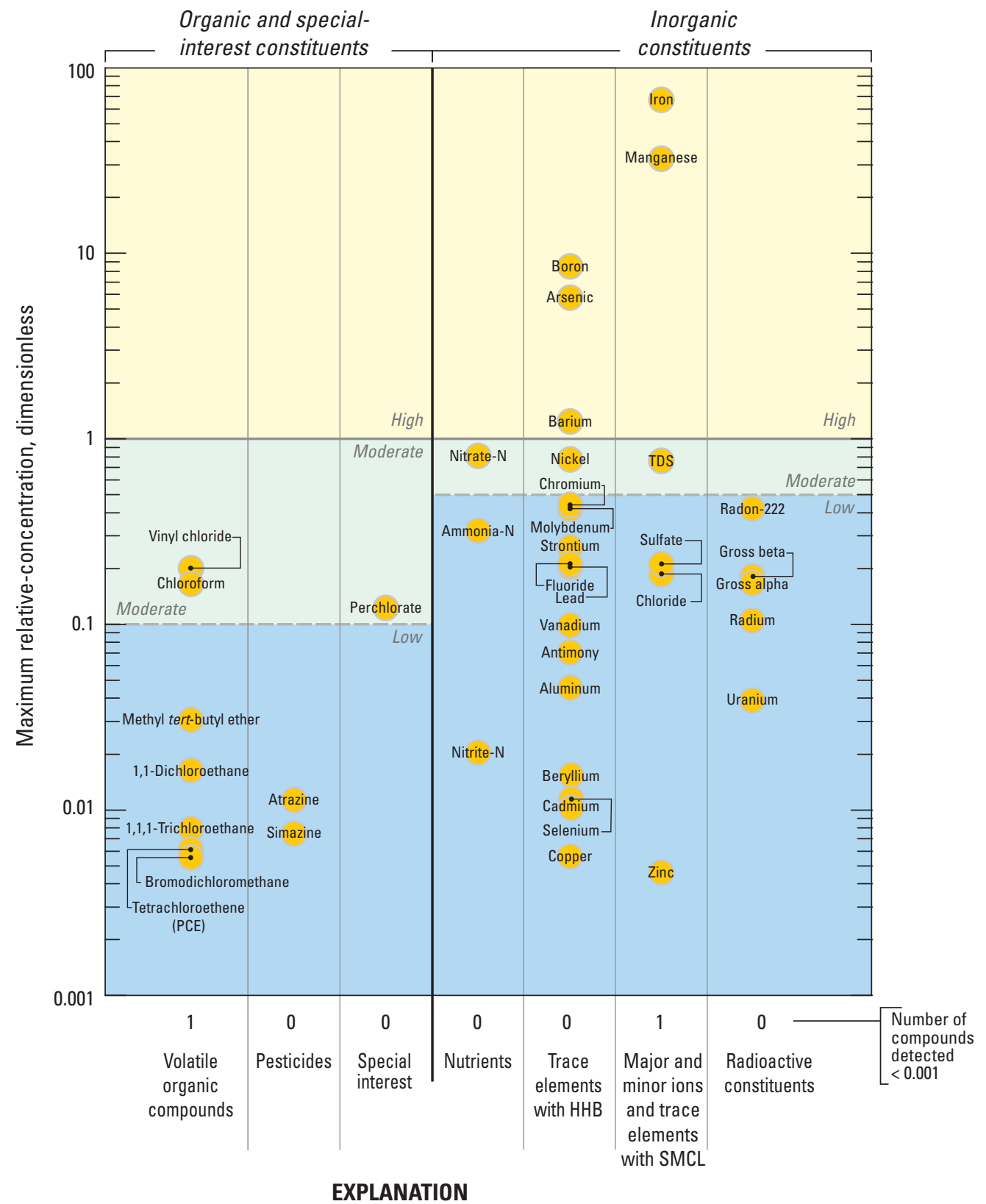

Zinc Name and center of symbol is the maximum relative-concentration for that constituentUnless indicated by following location line:

Abbreviations: N, nitrogen; TDS, total dissolved solids; HHB, human-health-based benchmark; SMCL, secondary maximum contaminant levels

Figure 10. Maximum relative-concentration of constituents detected in USGS-GAMA grid sites, by constituent class, Northern Coast Ranges study unit, 2009, California GAMA Priority Basin Project. 
$\boldsymbol{A}$

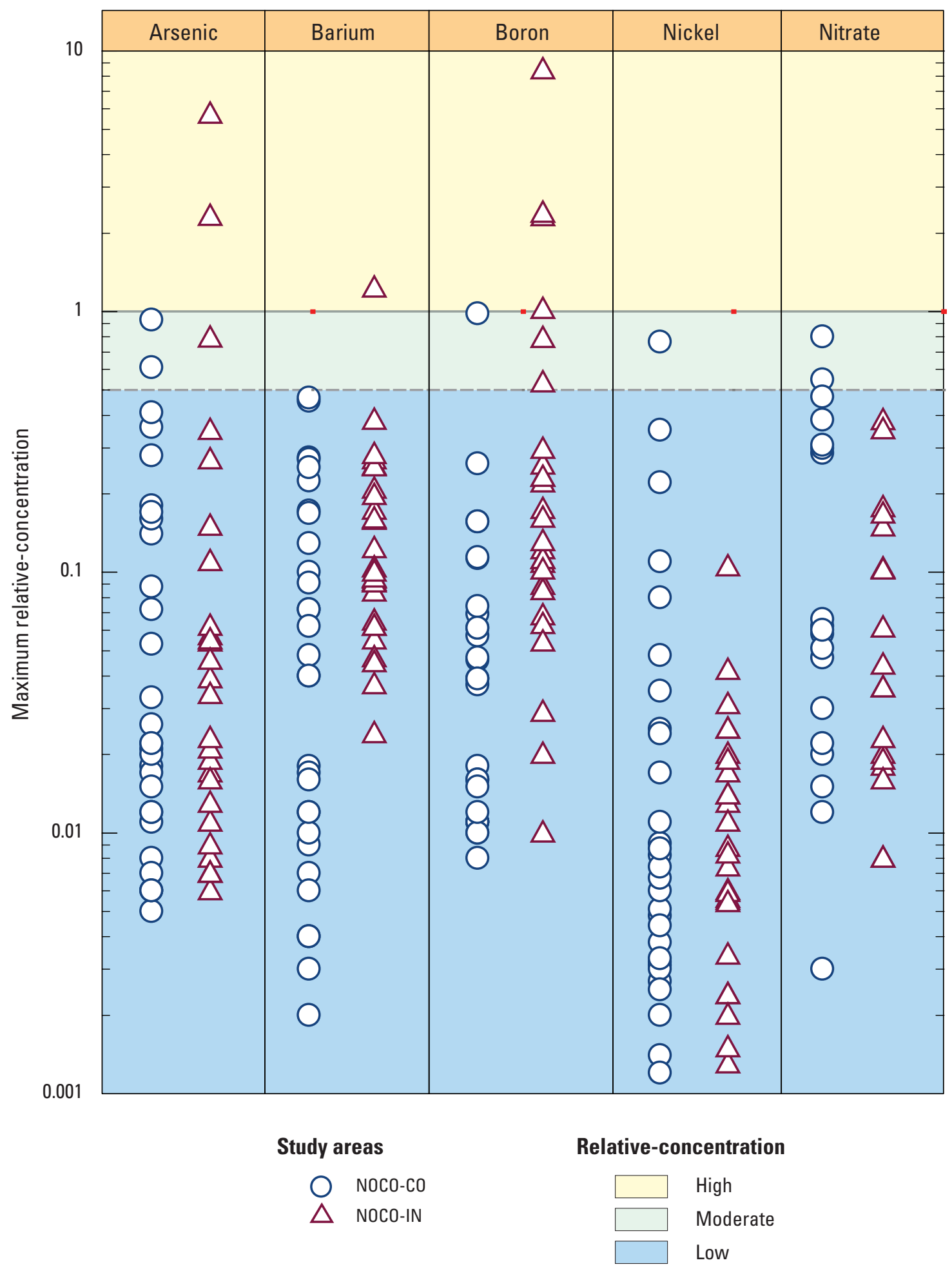

Figure 11. Relative-concentrations of $(A)$ selected constituents with health-based benchmarks and $(B)$ constituents with aestheticbased benchmarks in USGS-GAMA grid sites, Northern Coast Ranges study unit, 2009, California GAMA Priority Basin Project. [NOCO-IN, Interior Basins study area; NOCO-CO, Coastal Basins study area; TDS, total dissolved solids] 
B

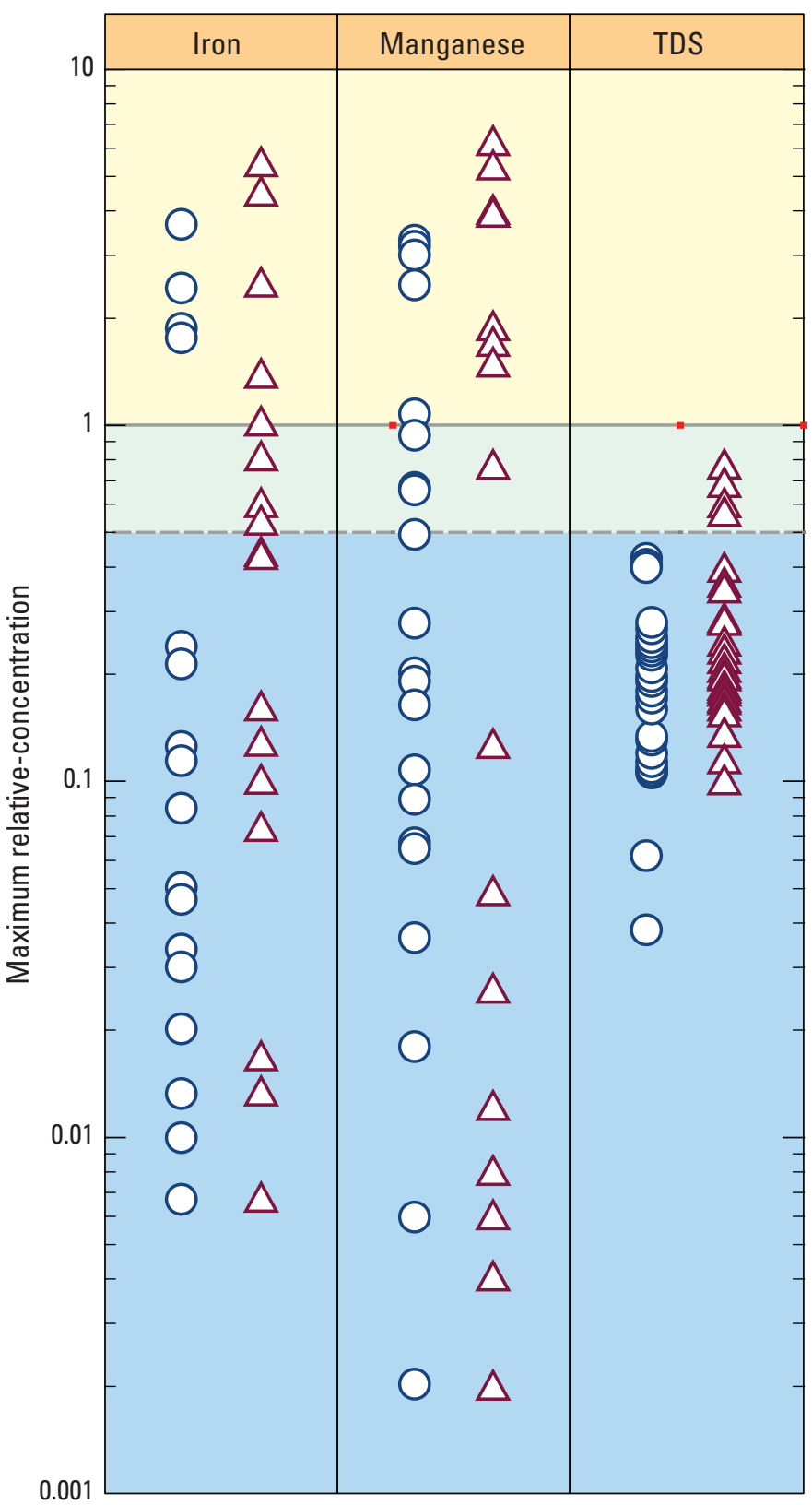

Study areas

$\begin{array}{ll}\triangle & \text { NOCO-CO } \\ \triangle & \text { NOCO-IN }\end{array}$

Figure 11. - Continued

\section{Understanding Assessment for Boron}

Boron is a naturally occurring semi-metallic element with high solubility in water. Natural sources of boron include igneous rocks, such as granite and pegmatite (as the mineral tourmaline), and evaporite minerals, such as borax, kernite, and colemanite (Hem, 1985; Reimann and de Caritat, 1998). Seawater contains 4,500 micrograms per liter ( $\mu \mathrm{g} / \mathrm{L})$ of boron (Summerhayes and others, 1996), and groundwater from marine sediments and shales average about $0.1 \mu \mathrm{g} / \mathrm{L}$ boron (Ryan and Langmuir, 1993). Boron also is associated with shallow thermal springs, deep thermal waters, and volcanic activity (Hem, 1989; Webster and Nordstrom, 2003; Kulongoski and others, 2010; Forrest and others, 2013). Boron can occur in wastewater because borax is a component of many detergents. Other anthropogenic uses of boron compounds include semiconductors, insecticides, preservatives, chemical reagents, and fertilizers. Boron is an essential nutrient for plants, but is toxic to plants at high concentrations (Hem, 1989). The comparison benchmark used for boron in this study was the CDPH NL-CA of $1,000 \mu \mathrm{g} / \mathrm{L}$ (California Department of Public Health, 2010). At concentrations greater than the HAL-US of $6,000 \mu \mathrm{g} / \mathrm{L}$, boron may adversely affect fetal development (U.S. Environmental Protection Agency, 2008). Boron is highly mobile because no mineral has a low enough solubility to provide an upper limit to its concentration range (Ryan and Langmuir, 1993).

Boron was detected at high relative-concentrations in 8.6 percent of the primary aquifer system and at moderate relative-concentrations in 5.2 percent (table 7). Boron concentrations generally are higher in the NOCO-IN study area than in the NOCO-CO study area (table 6). All of the high relative-concentrations of boron were detected in the NOCO-IN study area, but moderate relative-concentrations were detected in both study areas (figs. 11A, 12; tables $\mathrm{C} 1$, C2). Boron concentrations were found to be negatively correlated with DO (table 9) and were significantly higher in groundwater with anoxic rather than oxic conditions (table 6; fig. 14D). All of the sites with high and moderate relativeconcentrations of boron had anoxic groundwater conditions (table B5).

Multiple lines of evidence suggest that the elevated boron concentrations found in the NOCO study unit are most likely due to groundwater mixing with hydrothermal systems within the NOCO-IN study area, including (1) elevated groundwater temperatures, (2) groundwater chemistry characteristics similar to those of geothermal waters, and (3) proximity to known geothermal areas.

Samples with high and moderate relative-concentrations of boron have elevated groundwater temperatures. Boron concentrations were significantly positively correlated with field water temperature (table 9; fig. 14A). The median temperature $\left(18.0^{\circ} \mathrm{C}\right)$ for the 7 samples with high and moderate relative-concentrations of boron was significantly greater than the median temperature $\left(14.5^{\circ} \mathrm{C}\right)$ for the other 51 groundwater samples in the NOCO study unit (Wilcoxon rank-sum: $p=0.006$ ). Specifically, the site with the highest 
Table 8A. Summary of aquifer-scale proportions for inorganic constituent classes, Northern Coast Ranges study unit, 2009, California GAMA Priority Basin Project.

[Relative-concentration categories: high, concentration of at least one constituent in the class greater than its benchmark; moderate, concentration of at least one constituent in the class was greater than half of its benchmark and no constituents in the class had concentrations greater than their benchmarks; low, concentrations of all constituents in the class were less than or equal to half of the benchmark, including non-detections. Abbreviation: GAMA, Groundwater Ambient Monitoring and Assessment Program]

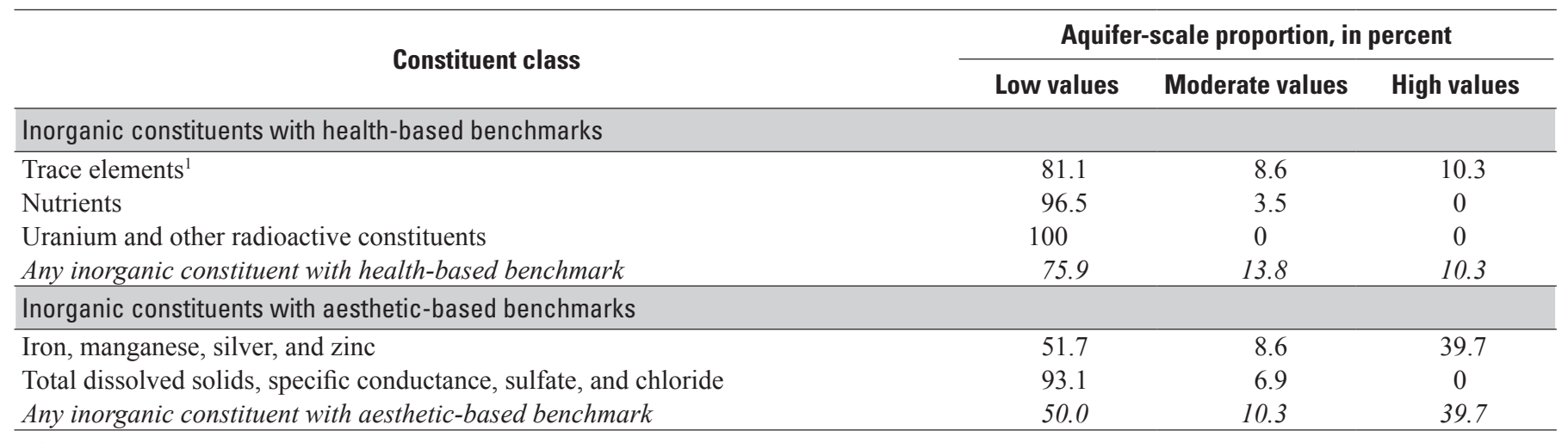

${ }^{1}$ Includes the minor element fluoride because it has a health-based benchmark.

Table 8B. Summary of aquifer-scale proportions for organic and special-interest constituent classes, Northern Coast Ranges study unit, 2009, California GAMA Priority Basin Project.

[Relative-concentration categories: high, concentration of at least one constituent in the class greater than its benchmark; moderate, concentration of at least one constituent in the class was greater than one-tenth of its benchmark and no constituents in the class had concentrations greater than their benchmarks; low, concentrations of all constituents in the class were less than or equal to one-tenth of the benchmark. Abbreviation: GAMA, Groundwater Ambient Monitoring and Assessment Program]

\begin{tabular}{|c|c|c|c|c|}
\hline Constituent class & \multicolumn{4}{|c|}{ Aquifer-scale proportion, in percent } \\
\hline \multicolumn{5}{|l|}{ Volatile organic compounds } \\
\hline Solvents & 91.4 & 8.6 & 0 & 0 \\
\hline Trihalomethanes & 75.9 & 22.4 & 1.7 & 0 \\
\hline Any volatile organic compound with health-based benchmark & 61.9 & 36.2 & 1.7 & ${ }^{1} 0.2$ \\
\hline Pesticides and pesticide degradates ${ }^{2}$ & 89.7 & 10.3 & 0 & 0 \\
\hline
\end{tabular}

${ }^{1}$ Spatially weighted aquifer-scale proportion value.

${ }^{2}$ Only herbicides were detected. 

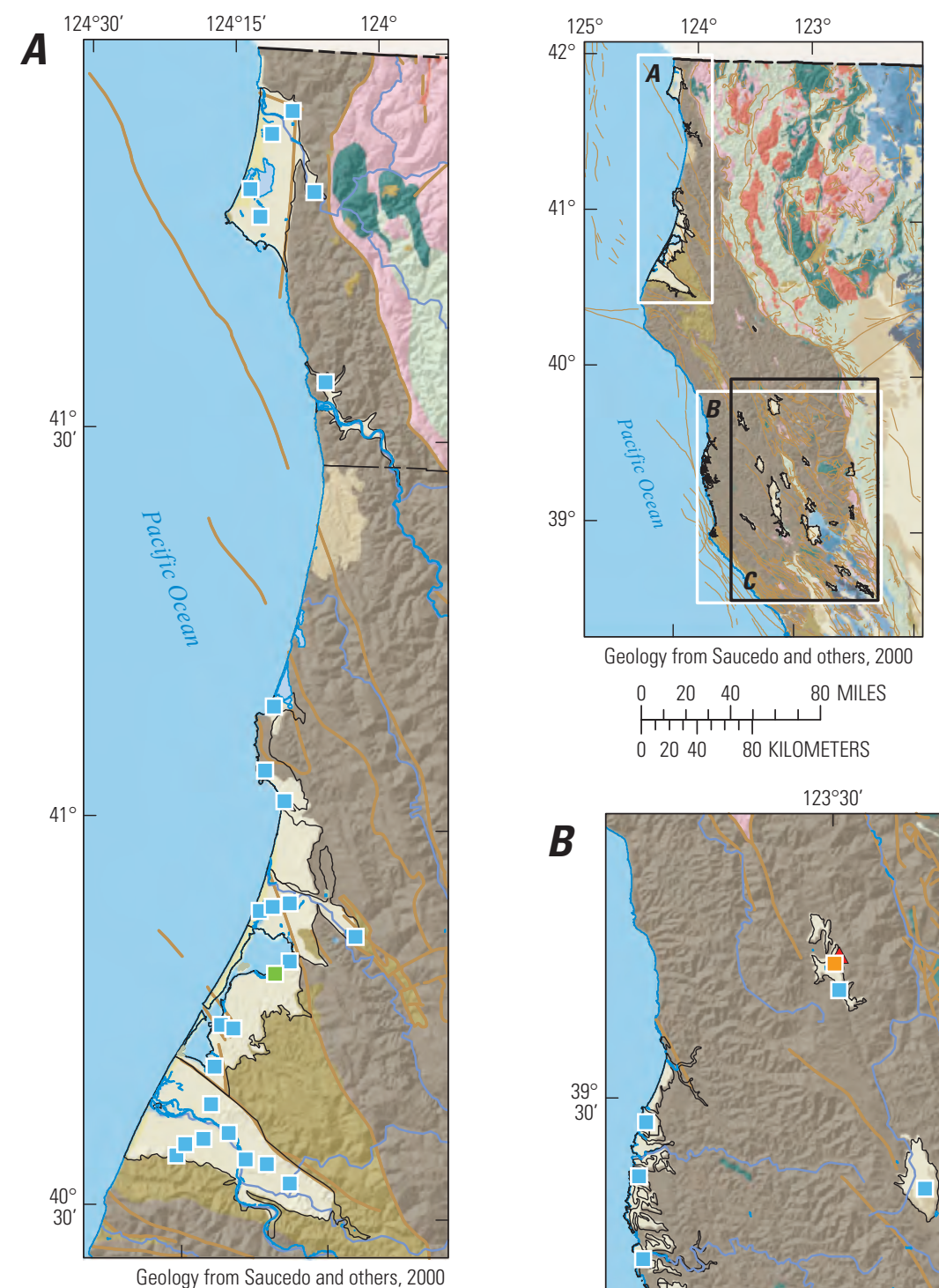

\section{EXPLANATION}

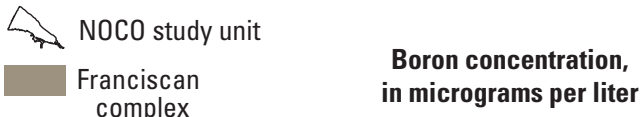
Plio-Pleistocene USGS-GAMA grid well sediment NOCO study unit

Quaternary alluvium

Quaternary other $\quad \leq 500$ (Low) sediment

Quarternary, mafic

volcanics
Pyroclastic volcanics

\section{Tertiary, mafic} volcanics

$>500$ to $\leq 1,000$ (Moderate)

—1,000 (High)

Tertiary nonmarine sediment

Tertiary marine sediment Granitic rocks Metamorphic other

Metasediment

Ultramafic/mafic - Fault

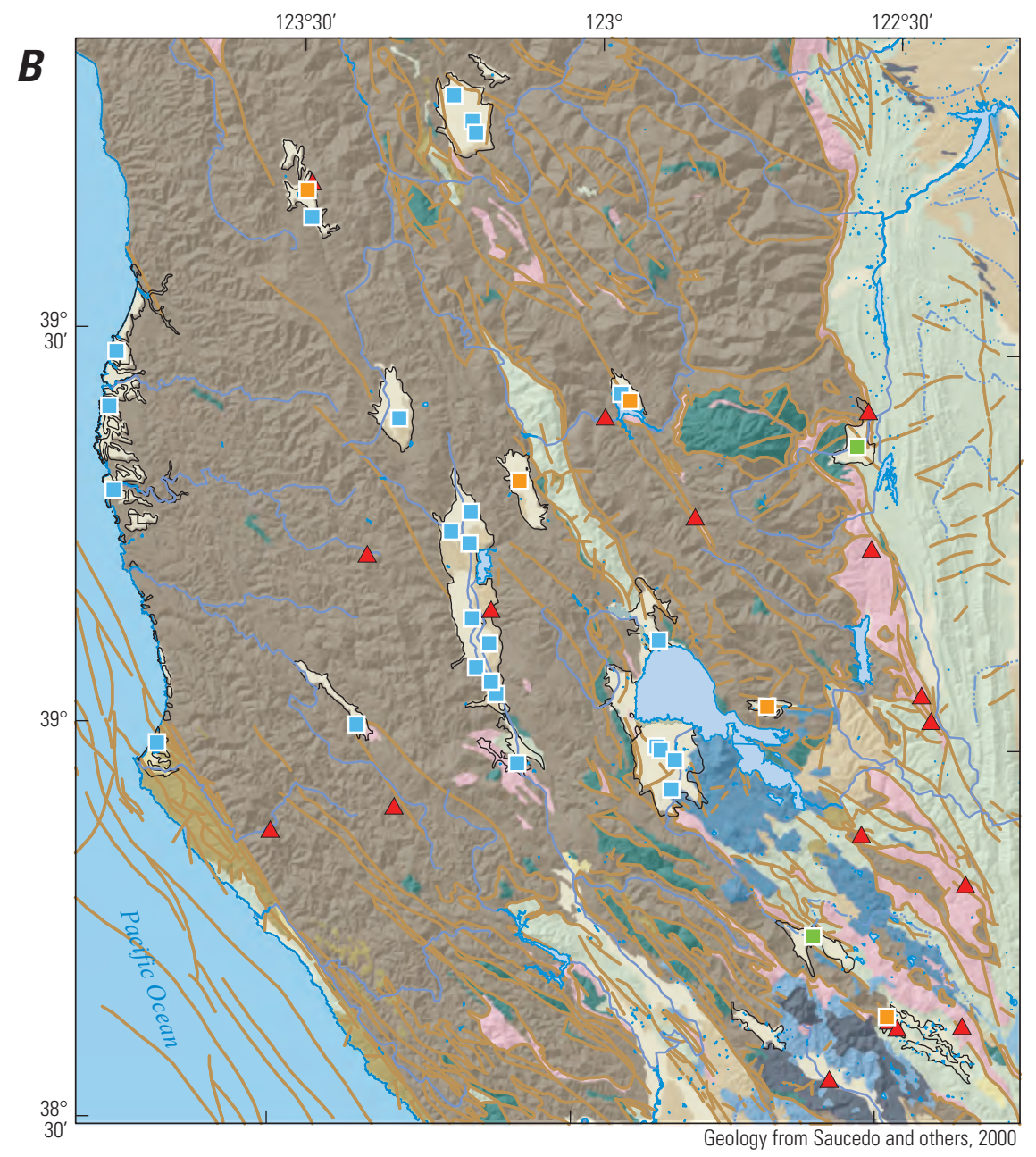

Figure 12. Relative-concentrations of boron in USGS-GAMA grid sites and geologic features in the $(A)$ Coastal Basins study area and $(B)$ Interior Basins study area, and $(C)$ geologic formations, locations of hot springs and geothermal wells, and approximate boundaries of the Napa and Sonoma Valleys and the Geysers Steam Field, Northern Coast Ranges (NOCO) study unit, 2009, California GAMA Priority Basin Project. 


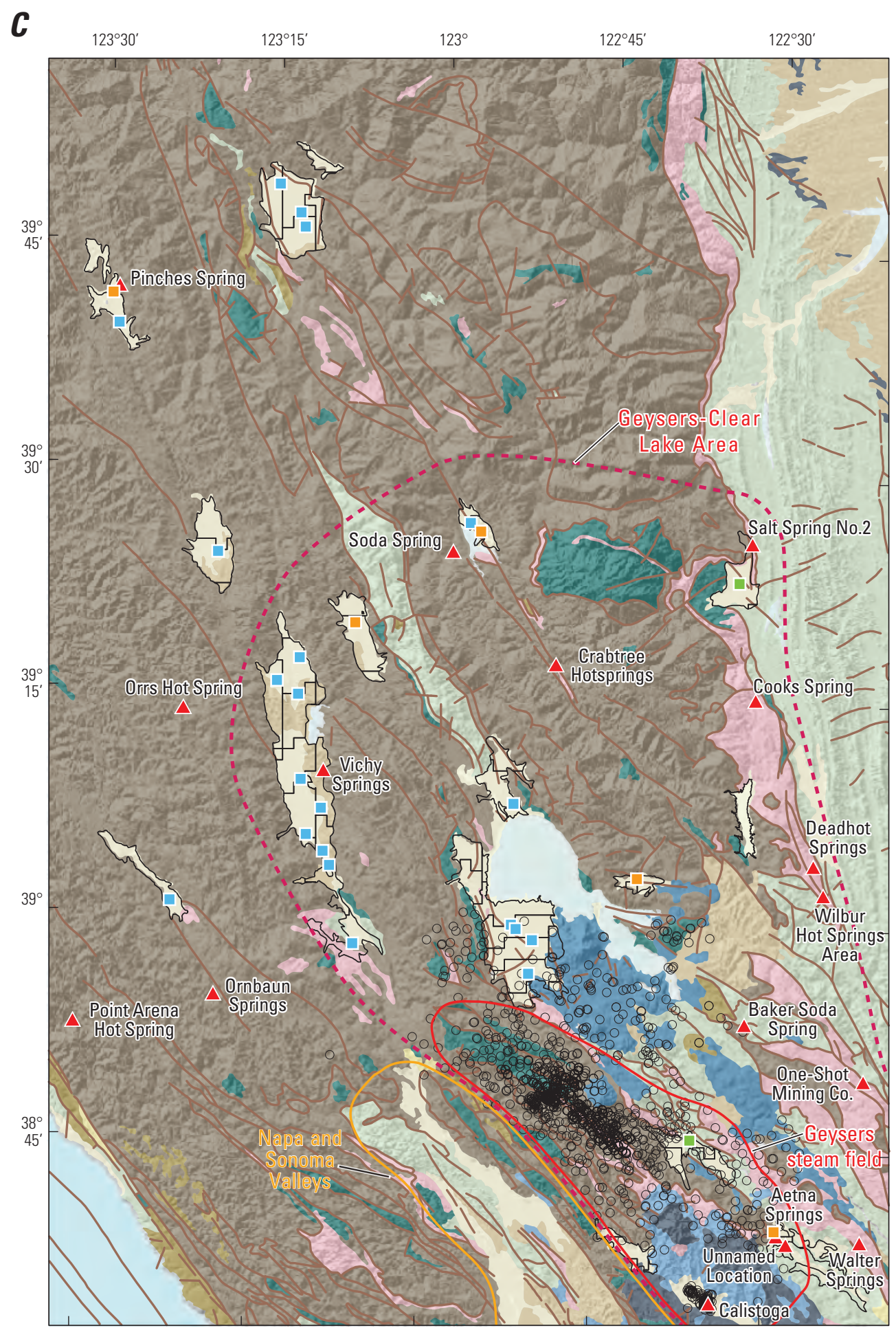

\section{EXPLANATION}

$\square$ NOCO study unit

Franciscan complex

Plio-Pleistocene sediment

Quaternary alluvium

Quaternary other sediment

Quarternary, mafic volcanics

Pyroclastic volcanics

Tertiary, mafic volcanics

Tertiary marine sediment

Metamorphic other

Metasediment

Ultramafic/mafic

$\square$ Lakes

— Fault

- Geothermal well

$\Delta$ Hot spring

Boron concentration, in micrograms per liter USGS-GAMA grid well NOCO study unit
$\leq 500$ (Low)
$>500$ to $\leq 1,000$ (Moderate)
- >1,000 (High)

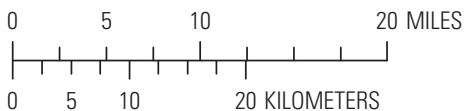

Geology from Saucedo and others, 2000

Figure 12. - Continued 

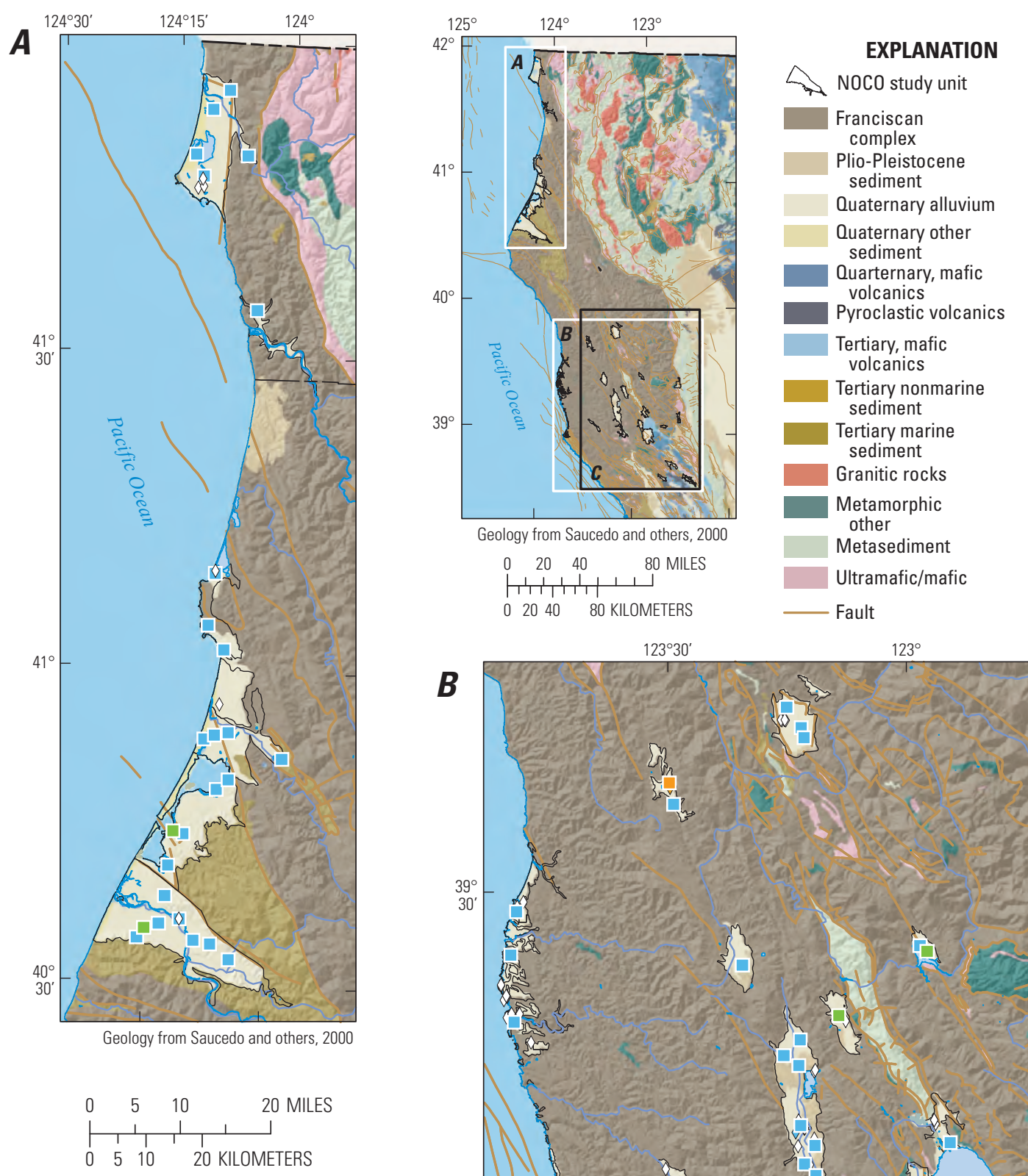
Arsenic concentration, in micrograms per liter USGS-GAMA grid well NOCO study unit
$\leq 5$ (Low)
$>5$ to $\leq 10$ (Moderate)
$>10$ (High)
CDPH site
$\diamond$ Non-detection
$\diamond \leq 5$ (Low)
$\diamond>10$ (High)

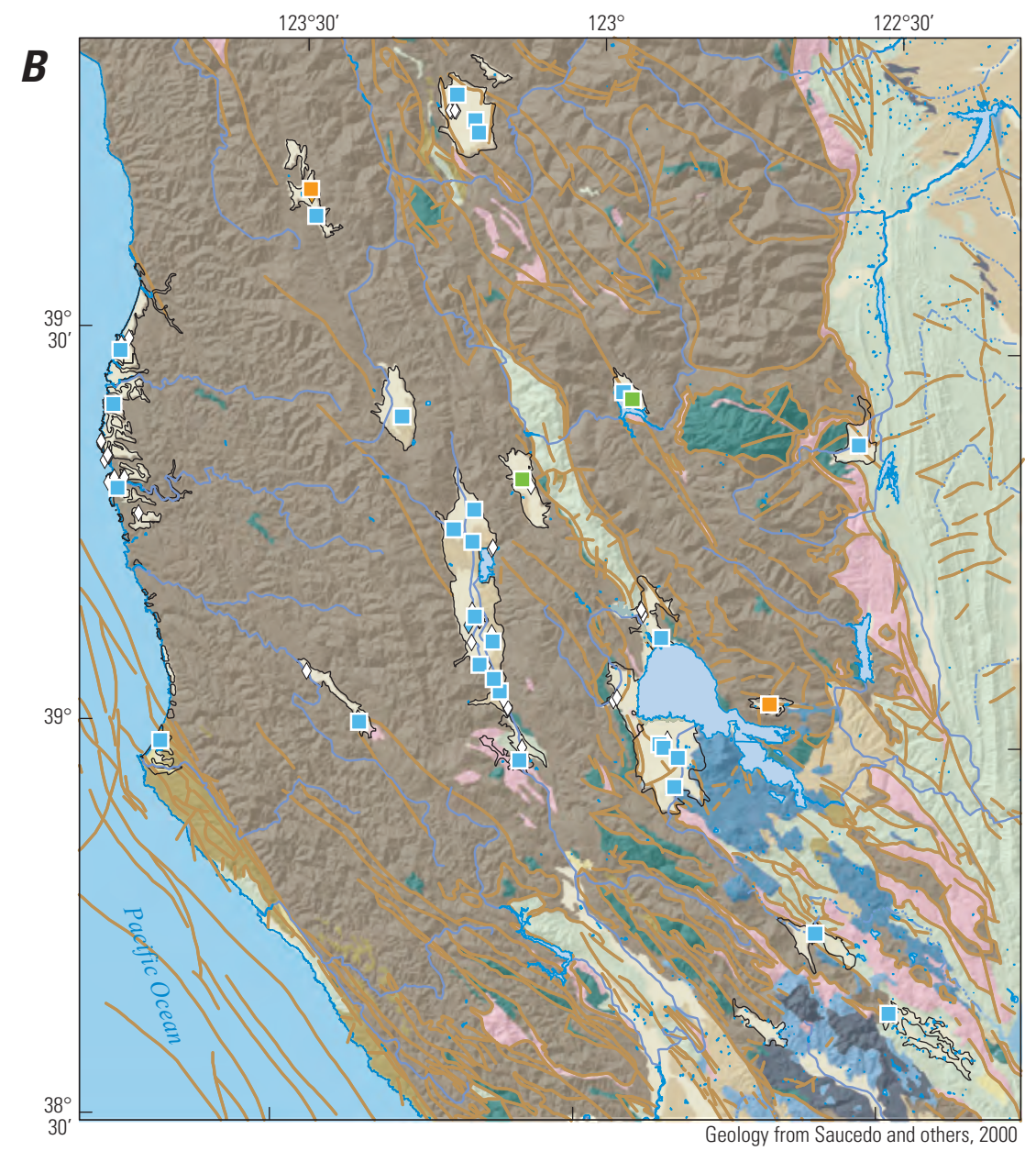

Figure 13. Relative-concentrations of arsenic in USGS-GAMA grid sites, CDPH sites for the period June 1, 2006-June 1, 2009, from the CDPH water-quality database, and geologic features in the $(A)$ Coastal Basins study area and $(B)$ Interior Basins study area and (C) geologic formations, locations of hot springs and geothermal wells, and approximate boundaries of the Napa and Sonoma Valleys and the Geysers Steam Field Northern Coast Ranges (NOCO) study unit, 2009, California GAMA Priority Basin Project. 


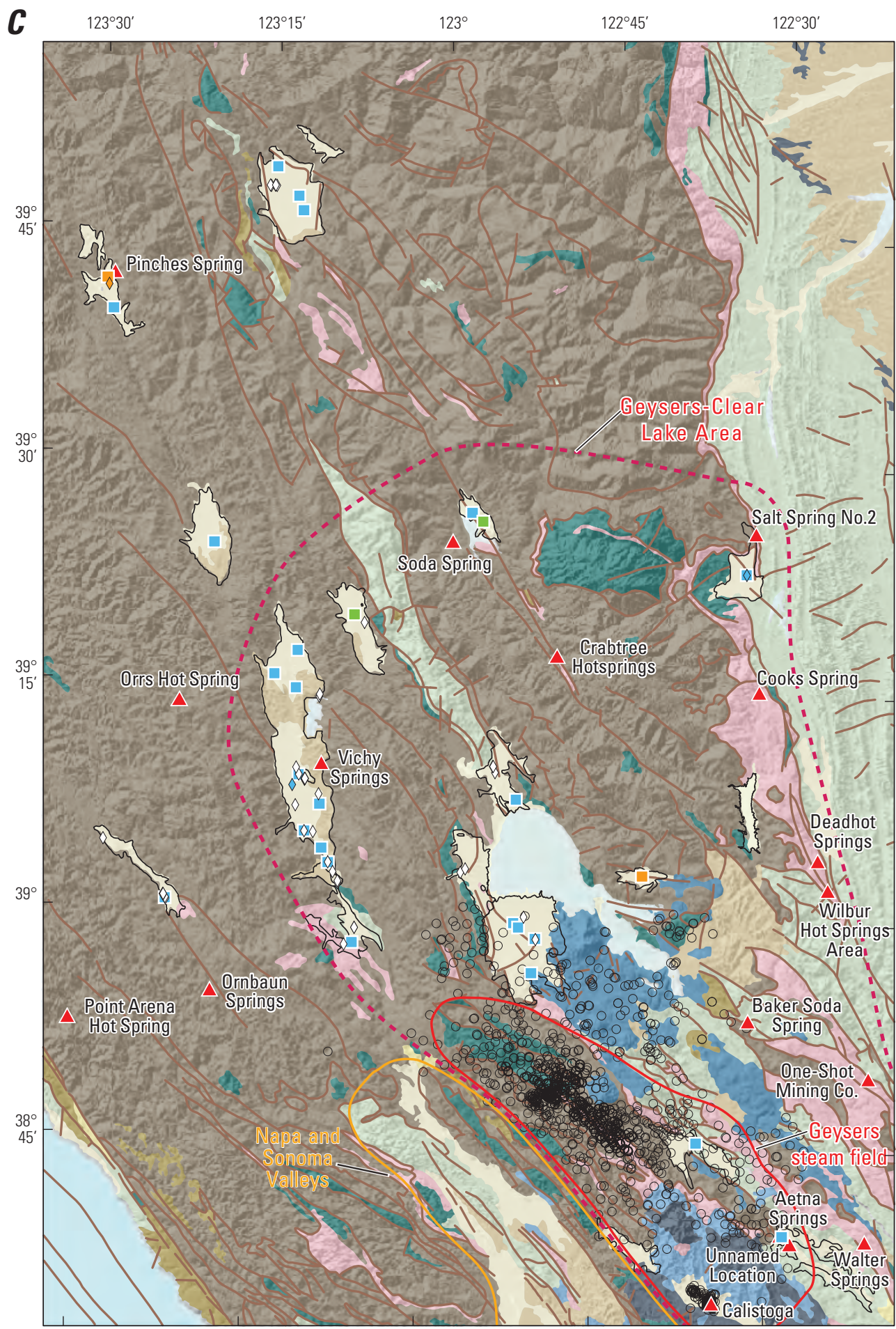

\section{EXPLANATION}

$\square$ NOCO study unit

Franciscan complex

Plio-Pleistocene sediment

Quaternary alluvium

Quaternary other sediment

Quarternary, mafic volcanics

Pyroclastic volcanics

Tertiary, mafic volcanics

Tertiary marine sediment

Metamorphic other

Metasediment

Ultramafic/mafic

$\square$ Lakes

_ Fault

○ Geothermal well

$\Delta$ Hot spring

Arsenic concentration, in micrograms per liter

USGS-GAMA grid well NOCO study unit

$\leq 5$ (Low)

$>5$ to $\leq 10$ (Moderate)

$>10$ (High)

CDPH site

$\diamond$ Non-detection

$\diamond \leq 5$ (Low)

$\diamond>10$ (High)

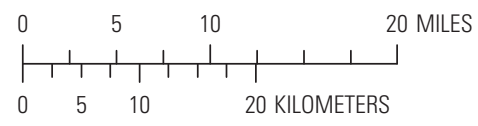

Geology from Saucedo and others, 2000

Figure 13. - Continued 

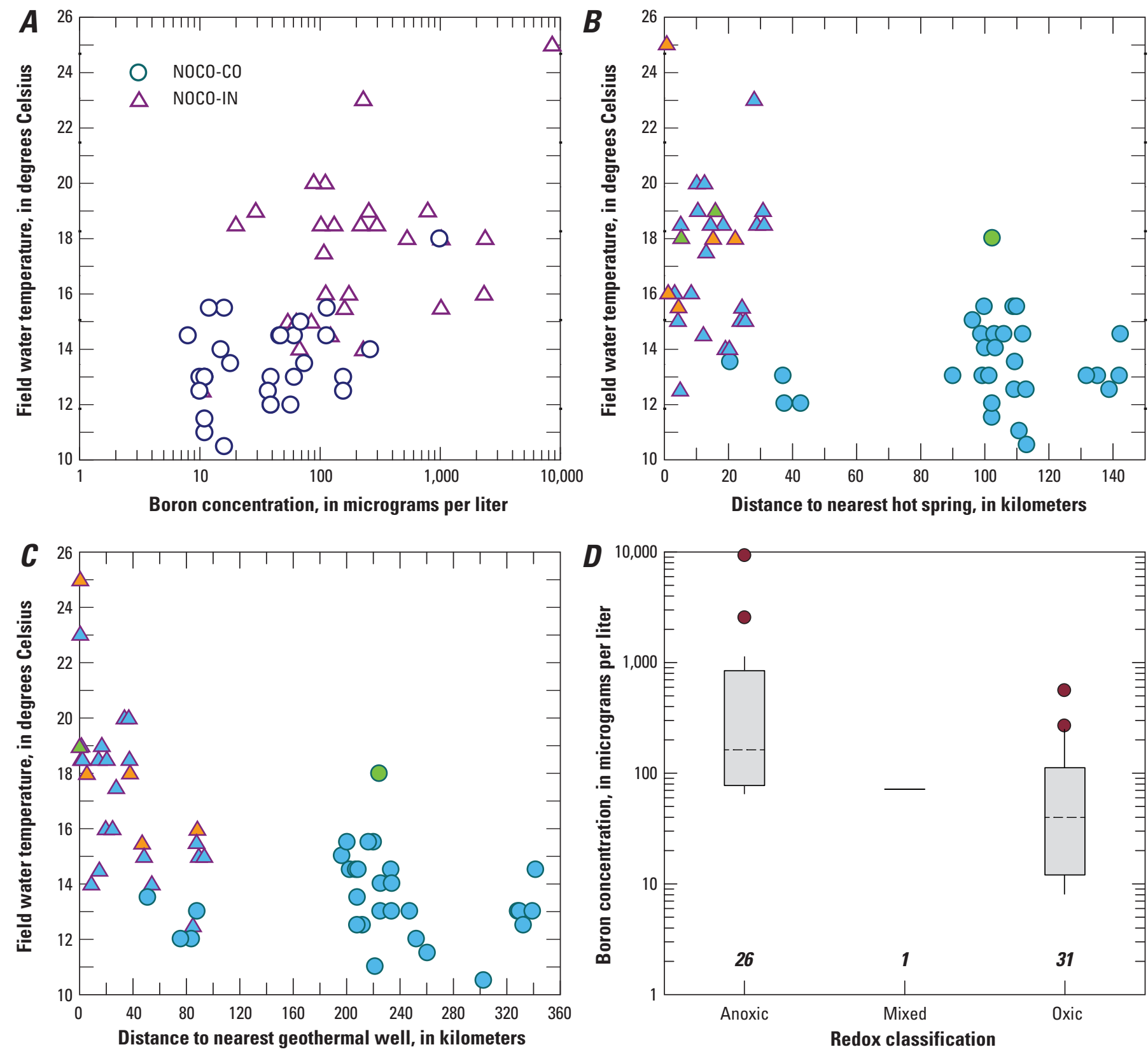

\section{EXPLANATION}
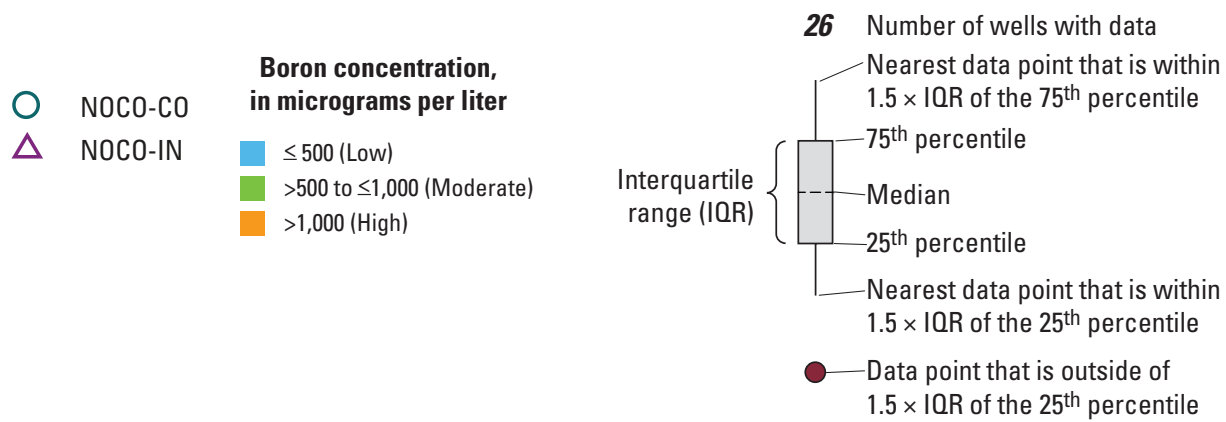

Figure 14. Boron concentrations relative to $(A)$ field water temperature, $(B)$ field water temperature and distance to nearest hot spring, $(C)$ field water temperature and distance to nearest geothermal well, and $(D)$ redox classification in USGS-GAMA grid sites sampled for the Northern Coast Ranges study unit, 2009, California GAMA Priority Basin Project. [NOCO-IN, Interior Basins study area; NOCO-CO, Coastal Basins study area] 
boron concentration (NOCO-IN-22; 8,470 $\mu \mathrm{g} / \mathrm{L}$ ) had a field water temperature of $25.0^{\circ} \mathrm{C}$ (table B3). These results follow the findings in previous studies in the Geysers-Clear Lake area, which classified groundwater as being under geothermal influence if temperatures were $>19.0^{\circ} \mathrm{C}$ (Goff and others, 1993; Donnelly-Nolan and others, 1993).

Samples with high and moderate relative-concentrations of boron exhibit groundwater chemistry characteristics similar to those of geothermal waters. Groundwater data appear to show a similar pattern of occurrences of hydrothermal system indicators as that noted in the Geysers-Clear Lake area (Donnelly-Nolan and others, 1993; Goff and others, 1993; Peters, 1993) and in the Napa and Sonoma Valleys (Forrest and others, 2013). The shared characteristics of geothermal waters in these hydrothermal systems include raised water temperatures, near neutral $\mathrm{pH}$, elevated concentrations of boron, arsenic, and lithium (in varied degrees), and high helium isotope ratios.

Samples with high and moderate relative-concentrations of boron all had near-neutral $\mathrm{pH}$ values, which ranged from 6.0 to 7.5 and had a median of 6.8 (table B5). Boron and arsenic concentrations were significantly correlated with each other (Spearman's $r$ o test, $\mathrm{p}=0.002$, rho $=0.56$ ). Two of the sites with high relative-concentrations of boron (NOCO-IN-05 and NOCO-IN-27) also had high relativeconcentrations of arsenic, and two additional sites with high relative-concentrations of boron (NOCO-IN-11 and NOCO-IN-15) had moderate relative-concentrations of arsenic (figs. 12, 13). Boron and lithium concentrations were also significantly correlated with each other (Spearman's rho test, $\mathrm{p}=0.001$, rho $=0.43)$. Helium isotope ratios $\left({ }^{3} \mathrm{He} /{ }^{4} \mathrm{He}\right)$ are often discussed as $\mathrm{R} / \mathrm{Ra}$ rather than as the ratio itself. $\mathrm{R} / \mathrm{Ra}$ is the ratio in the sample (R) divided by the ${ }^{3} \mathrm{He} /{ }^{4} \mathrm{He}$ ratio in the atmosphere $\left(\mathrm{Ra}=1.4 \times 10^{-6}\right) . \mathrm{R} / \mathrm{Ra}>1.0$ generally indicates contribution from the Earth's mantle (Kulongoski and others, 2003), and median mantle helium in the western United States has an $\mathrm{R} / \mathrm{Ra}=6.0$ (Dodson and others, 1998). The sample from NOCO-IN-22 (the sample with the highest boron concentration) had an $\mathrm{R} / \mathrm{Ra}=5.0$ (table E1).

Samples with high and moderate relative-concentrations of boron are located near known hydrothermal areas. Proximity of USGS-GAMA sites to known hydrothermal areas was assessed in three ways: (1) sample sites located within the approximate physical boundaries of geothermal areas, (2) distance from hot spring listed in the USGS MRDS, and (3) distance from geothermal well listed in the DOGGR database.

Four of the seven samples with high and moderate relative-concentrations of boron are from sites that are spatially located within the approximate boundaries of the Geysers-Clear Lake area (figs. 12B,C). Specifically, NOCO-IN-27 is located in the central portion of the study area, within the main mass of the Clear Lake volcanic field; NOCO-IN-22 and NOCO-IN-25 are located in the southern portion of the study area, near the Geysers steam field; and NOCO-IN-26 is located in the portion of the study area, in the eastern Clear Lake region (fig. 12B).
Boron concentrations were negatively correlated with the distance to nearest hot spring listed in the USGS MRDS and distance to nearest geothermal well listed in the DOGGR database (table 9; figs. 14B, C). The median distance from the nearest hot spring for the 7 samples with high and moderate relative-concentrations of boron was $5.3 \mathrm{~km}$; the median distance for the other 51 groundwater samples was $66.1 \mathrm{~km}$. Three of the sites with high relativeconcentrations of boron were relatively near named hot springs (NOCO-IN-05: Pinches Spring; NOCO-IN-15: Soda Spring; NOCO-IN-22: Aetna Springs) as was one of the sites with a moderate relative-concentration (NOCO-IN-26: Salt Spring No. 2; U.S. Geological Survey, 2005; fig. 12; table B3). The median distance from nearest geothermal well for the 7 samples with high and moderate relative-concentrations of boron was $38.5 \mathrm{~km}$; the median distance for the other 51 groundwater samples was $145 \mathrm{~km}$. Specifically, NOCO-IN-22 was within $1 \mathrm{~km}$ of a geothermal well, and NOCO-IN-25 was $0.37 \mathrm{~km}$ from a geothermal well (California Department of Conservation, 2013).

There does not appear to be a causative relation between boron concentrations and aridity index, although they had a significant negative correlation (table 9). This result is most likely a function of aridity index being correlated with the geothermal explanatory factors (groundwater temperature and distance to nearest hot spring and geothermal well) rather than a causative relation that is explanatory of boron distribution in groundwater in the NOCO study unit.

The elevated groundwater temperatures, close relations among boron, arsenic, and lithium concentrations in the groundwater, helium isotope ratios, and proximity to known geothermal areas suggest that the primary source of boron in the NOCO study unit is geothermal waters.

\section{Understanding Assessment for Arsenic}

Arsenic is a naturally occurring semi-metallic trace element. Potential sources of arsenic to groundwater are natural or anthropogenic. Natural sources include the dissolution of arsenic-bearing minerals and desorption of arsenic from mineral surfaces. Potential anthropogenic sources of arsenic include mining of copper and gold ores, coal combustion, arsenical pesticides, arsenical veterinary pharmaceuticals, and wood preservatives (Welch and others, 2000). The MCL-US for arsenic was lowered from 50 to $10 \mu \mathrm{g} / \mathrm{L}$ in 2002 , and chronic exposure to arsenic concentrations between 10 and $50 \mu \mathrm{g} / \mathrm{L}$ in drinking water has been linked to increased cancer risk and to non-cancerous effects including skin damage and circulatory problems (U.S. Environmental Protection Agency, 2012). Arsenic solubility increases with increasing water temperature, such that geothermal systems often exhibit high arsenic concentrations (Ballantyne and Moore, 1988; Goff and others, 1993; Peters, 1993; Webster and Nordstrom, 2003; Forrest and others, 2013).

Arsenic was detected at high relative-concentrations in 3.4 percent of the primary aquifer system and at moderate relative-concentrations in 6.9 percent (table 7). All of the 
high relative-concentrations of arsenic were detected in the NOCO-IN study area (figs. 11, 13; tables C1, C2). Arsenic concentrations were significantly lower in modern groundwater than in groundwater with mixed or pre-modern ages (table 6; fig. 15A). Additionally, arsenic concentrations were positively correlated with well depth and depth to top-ofperforations (table 9). Arsenic concentrations were negatively correlated to DO (table 9), and arsenic concentrations were significantly higher in groundwater with anoxic conditions rather than oxic conditions (table 6).

Arsenic mobilization and distribution in groundwater is affected by the oxidation-reduction (redox) and $\mathrm{pH}$ conditions of the groundwater system. Arsenic concentrations are commonly found to be positively correlated with $\mathrm{pH}$ as a result of the desorption of arsenic from aquifer sediments with increasing pH (Belitz and others, 2003; Welch and others, 2006). Previous investigations and reviews of arsenic (for example, Welch and others, 2000, 2006; Frankenberger, 2002; Ravenscroft and others, 2009; Forrest and others, 2013) have attributed elevated arsenic concentrations in groundwater to three mechanisms: (1) the release of arsenic from dissolution of iron or manganese oxides under iron- or manganese-reducing (anoxic) conditions, (2) groundwater mixing with hydrothermal systems, and (3) arsenic desorption from aquifer sediments or inhibition of arsenic sorption to aquifer sediments as a result of oxic and alkaline groundwater conditions ( $\mathrm{pH}$ values $\geq 8.0$ ).

Whether arsenic was released by dissolution under anoxic conditions, groundwater mixing with hydrothermal systems, or desorption under oxic, high-pH conditions, the accumulation of elevated concentrations of arsenic in groundwater also requires favorable hydrologic conditions. Arsenic accumulation is favored by longer contact times between groundwater and aquifer materials and minimizing the amount of flushing of the system (Smedley and Kinniburgh, 2002).

Evidence for the first mechanism, release of arsenic under reducing conditions, in the NOCO study unit includes the association of high and moderate concentrations of arsenic with groundwater having iron- or manganesereducing conditions. Both of the sites having high relative-concentrations of arsenic (NOCO-IN-05 and NOCO-IN-27) and three of the four sites having moderate relative-concentrations (NOCO-IN-11, NOCO-IN-15, and NOCO-CO-21) had anoxic groundwater conditions (table B5). For these five sites with anoxic conditions and high or moderate relative-concentrations of arsenic, $\mathrm{pH}$ values ranged from 6.0 to 7.1. Four of these five sites also had high relative-concentrations of iron and manganese (all but NOCO-IN-15). The association of high iron and manganese

Table 9. Results of non-parametric (Spearman's rho method) analysis for correlations between selected water-quality constituents and potential explanatory factors, Northern Coast Ranges study unit, 2009, California GAMA Priority Basin Project.

[Explanation: Potential explanatory factors without significant correlations are not shown on this table. Spearman's rho test used and rho values shown. Significance level ( $\mathrm{p} \leq 0.05)$; Correlations with $r h o>0.2$ and (or) $\mathrm{p}$-values $\leq 0.05$ are shown in bold. Abbreviations: GAMA, Groundwater Ambient Monitoring and Assessment Program; USGS, U.S. Geological Survey; $\leq$, less than or equal to; >, greater than; $\geq$, greater than or equal to; ns, no significant correlation between factors; black text, significant positive correlation; red text, significant negative correlation; DOGGR, Division of Oil, Gas, and Geothermal Resources (California Department of Conservation); \%, percent]

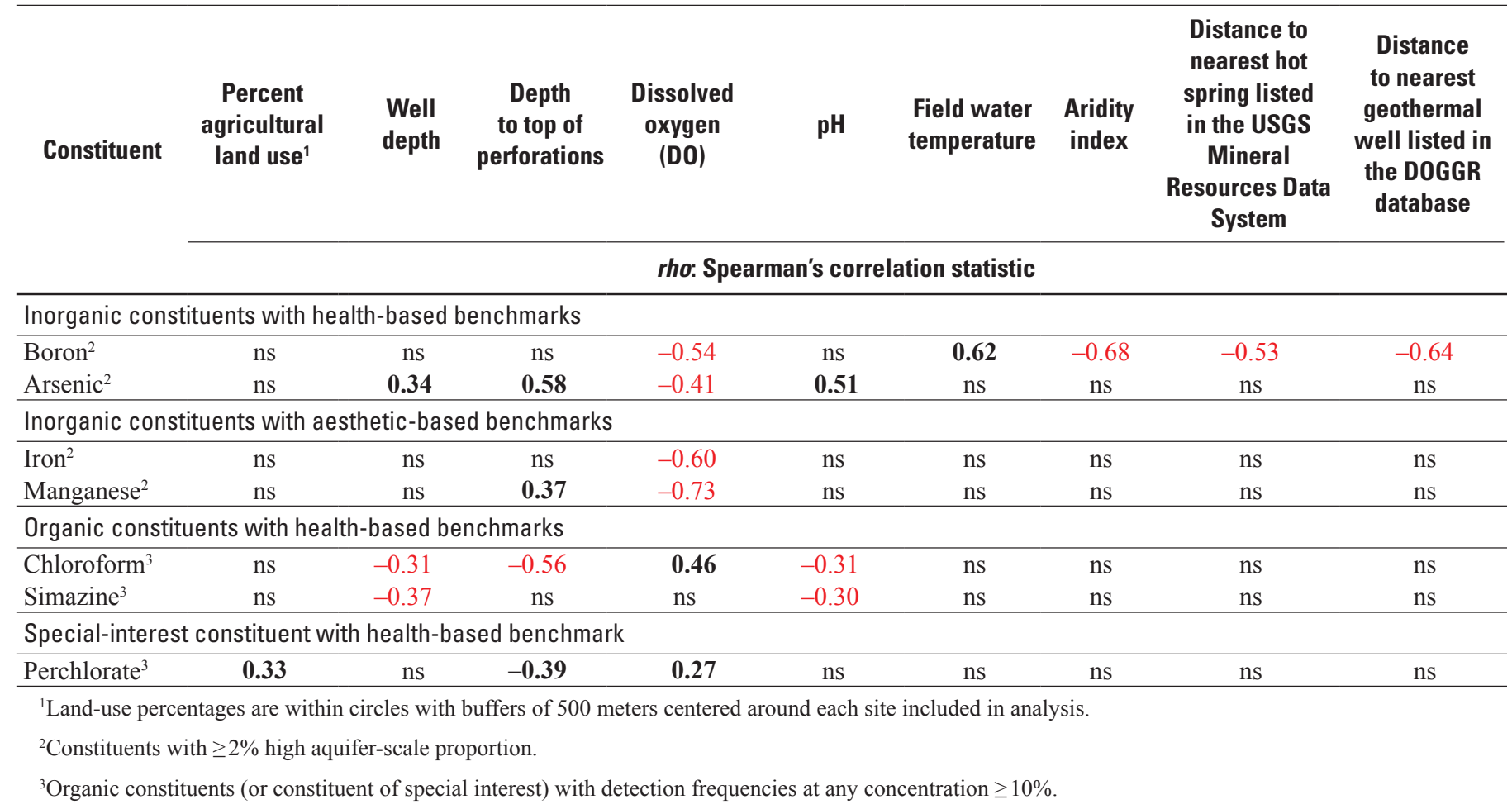



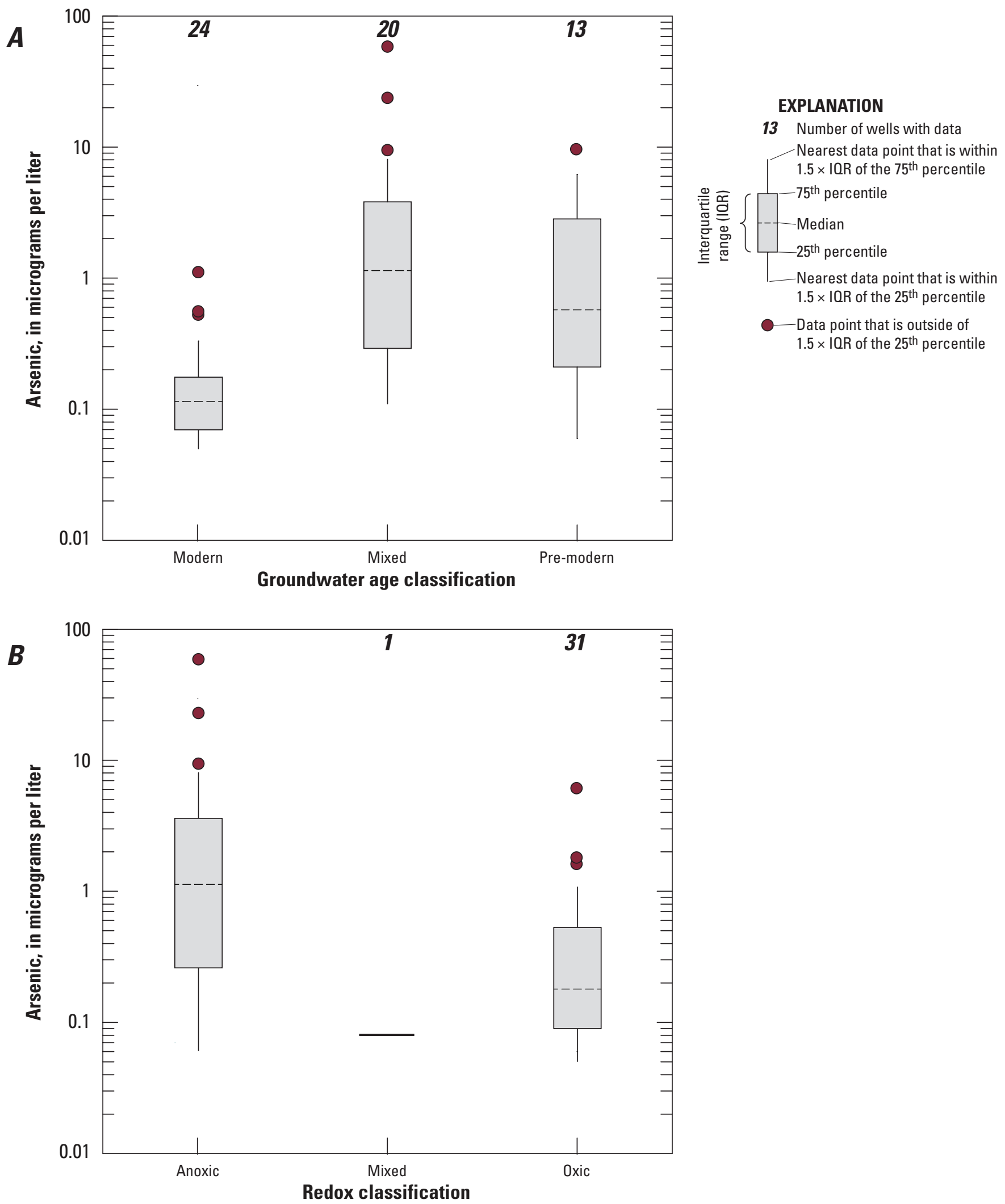

Figure 15. Arsenic concentrations relative to $(A)$ groundwater age classification and $(B)$ redox classification in USGS-GAMA grid sites sampled for the Northern Coast Ranges study unit, 2009, California GAMA Priority Basin Project. 
relative-concentrations, low DO (anoxic conditions), and $\mathrm{pH}<7.0$ at NOCO-IN-05, NOCO-IN-11, and NOCO-IN-27 suggests that reductive dissolution of iron and manganese oxides may account for portions of the high and moderate relative-concentrations of arsenic detected at these sites.

Evidence for the second mechanism, groundwater mixing with hydrothermal systems includes the association of high and moderate relative-concentrations of arsenic co-occurring with hydrothermal system indicators. As previously mentioned, arsenic and boron concentrations were significantly correlated with one other. Four of the sites in the NOCO-IN study area having high (NOCO-IN-05 and NOCO-IN-27) and moderate (NOCO-IN-11 and NOCO-IN-15) relative-concentrations of arsenic also had high relative-concentrations of boron (figs. 12, 13). Arsenic and lithium concentrations also were significantly correlated (Spearman's rho test, $\mathrm{p}=0.002$, rho $=0.41$ ).

There is minimal evidence for the third mechanism, desorption of arsenic from aquifer sediments or inhibition of arsenic sorption to aquifer sediments with increasing $\mathrm{pH}$. Arsenic concentrations were positively correlated with $\mathrm{pH}$ (table 9). Because only one site (NOCO-CO-03) had moderate relative-concentrations of arsenic, with oxic and relatively alkaline conditions ( $\mathrm{pH}$ of 7.7; table B5), the relation of arsenic concentrations and $\mathrm{pH}$ is most likely a result of the relation of $\mathrm{pH}$ to anoxic conditions, well depth, and groundwater age.

In summary, high and moderate relative-concentrations of arsenic can result from release of arsenic from aquifer sediments under iron- and manganese-reducing conditions, contribution from hydrothermal systems (when present), and accumulation with groundwater age, or from other sources that are not fully understood.

\section{Nutrients}

Nutrients, as a class, were not detected at high relativeconcentrations in the primary aquifer system of the NOCO study unit. Moderate relative-concentrations were detected in 3.5 percent of the primary aquifer system, and low relativeconcentrations were detected in 94.8 percent of the primary aquifer system (table 8A). Moderate relative-concentrations of nitrate occurred in the NOCO-CO study area (table C2; Mathany and others, 2011).

\section{Uranium and Other Radioactive Constituents}

The relative-concentrations of uranium and other radioactive constituents are low in the primary aquifer system of the NOCO study unit (table 8A). No detections of uranium or other radioactive constituents were greater than their associated water-quality benchmark during the current period of study or in the historical data (table 4).

\section{Inorganic Constituents with Aesthetic-Based Benchmarks}

Inorganic constituents with aesthetic-based benchmarks, as a class, were detected at high relative-concentrations (for one or more constituents) in 39.7 percent, moderate relative-concentrations in 10.3 percent, and low relativeconcentrations in 50.0 percent of the primary aquifer system (table 8A). High (39.7 percent) and moderate (8.6 percent) relative-concentrations of trace metals (iron and manganese) accounted for all of the high and most of the moderate aquiferscale proportions. Inorganic constituents with aesthetic-based benchmarks that are indicators of salinity (TDS, field specific conductance, sulfate, and chloride) had a moderate aquiferscale proportion of 6.9 percent of the primary aquifer system (table 8A). Among the salinity indicators, TDS was detected at moderate relative-concentrations in 6.9 percent of the primary aquifer system (table 7). Chloride had a concentration greater than its benchmark in at least one site in the CDPH waterquality database prior to June 1, 2006 (table 4), but not during the current period of study.

\section{Understanding Assessment for Iron and Manganese}

Potential natural sources of iron and manganese in groundwater include the dissolution of igneous and metamorphic rocks as well as the dissolution of various secondary minerals (Hem, 1989). Some rocks that contain significant amounts of iron and manganese have a relatively high composition of the minerals olivine, biotite, and hornblende. Potential anthropogenic sources of iron and manganese in groundwater include effluents associated with the steel and mining industries (Reimann and de Caritat, 1998) and soil amendments in the form of iron and manganese sulfates that are added to deficient soils to stimulate crop growth. Distributions of iron and manganese concentrations in groundwater are strongly influenced by redox conditions in the aquifer. In sediments, the oxyhydroxides of iron and manganese are common as coatings on mineral surfaces and as suspended particles (Sparks, 1995). Under anoxic conditions, however, the process of reductive dissolution can release these elements from mineral surfaces, and iron and manganese may remain in solution in aquifer systems (Sparks, 1995).

In the NOCO study unit, iron was detected at high relative-concentrations in 25.9 percent of the primary aquifer system and moderate relative-concentrations in 5.2 percent (table 7). Manganese was detected at high relative-concentrations in 39.7 percent and at moderate relative-concentrations in 8.6 percent of the primary aquifer system. High relative-concentrations of iron and manganese occurred in both study areas (figs. 11, 16, 17; tables C1, $\mathrm{C} 2$ ). Iron and manganese were significantly correlated with each other (Spearman's rho test, $\mathrm{p}<0.001$, rho $=0.74$ ). Iron and manganese concentrations were significantly higher in pre-modern and mixed-age groundwater than in modern groundwater (table 6). In addition, manganese concentrations had a significant positive correlation with 

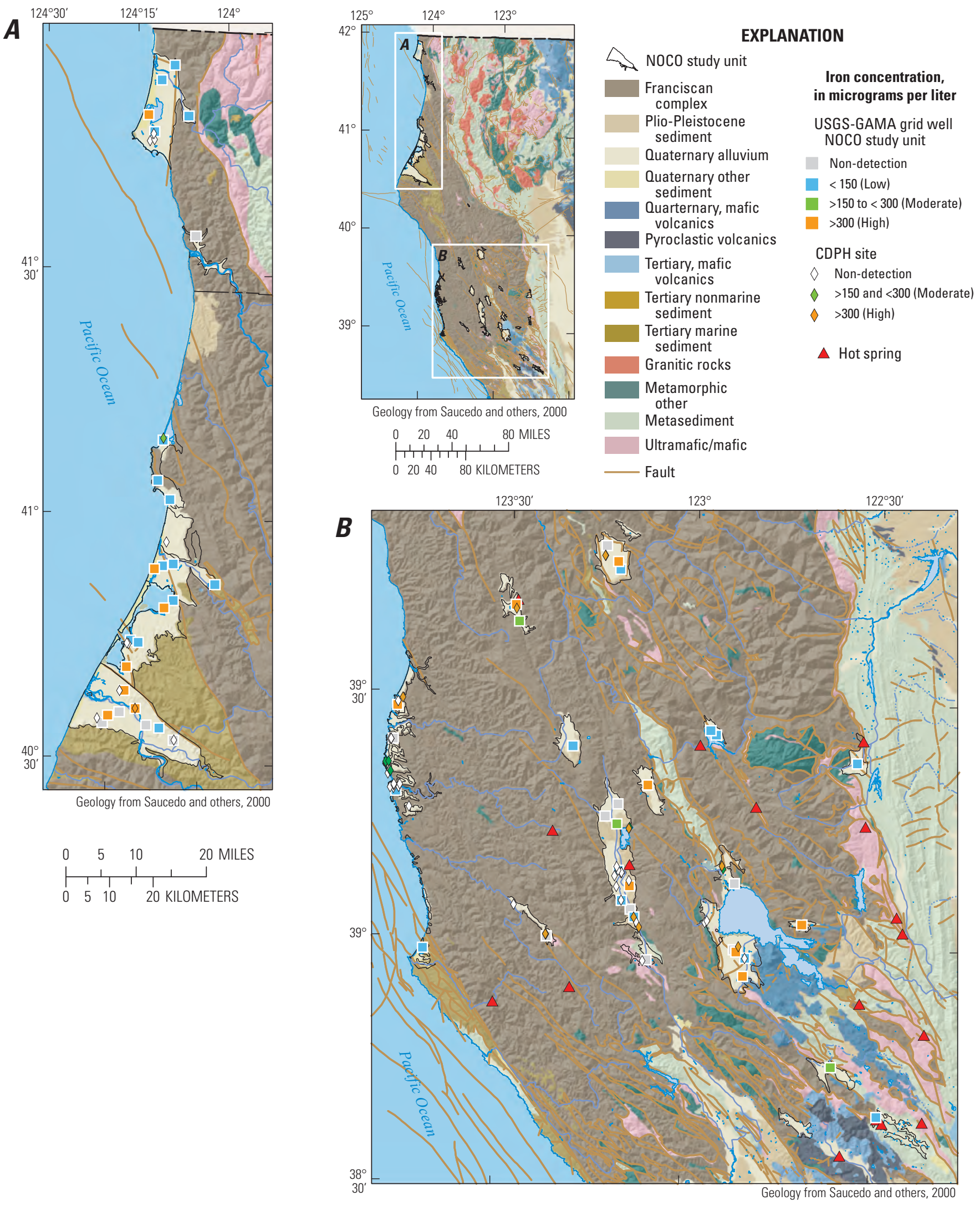

Figure 16. Relative-concentrations of iron in USGS-GAMA grid sites and CDPH sites for the period June 1, 2006-June 1, 2009, from the $\mathrm{CDPH}$ water-quality database in the $(A)$ Coastal Basins study area and $(B)$ Interior Basins study area, Northern Coast Ranges study unit, 2009, California GAMA Priority Basin Project. 

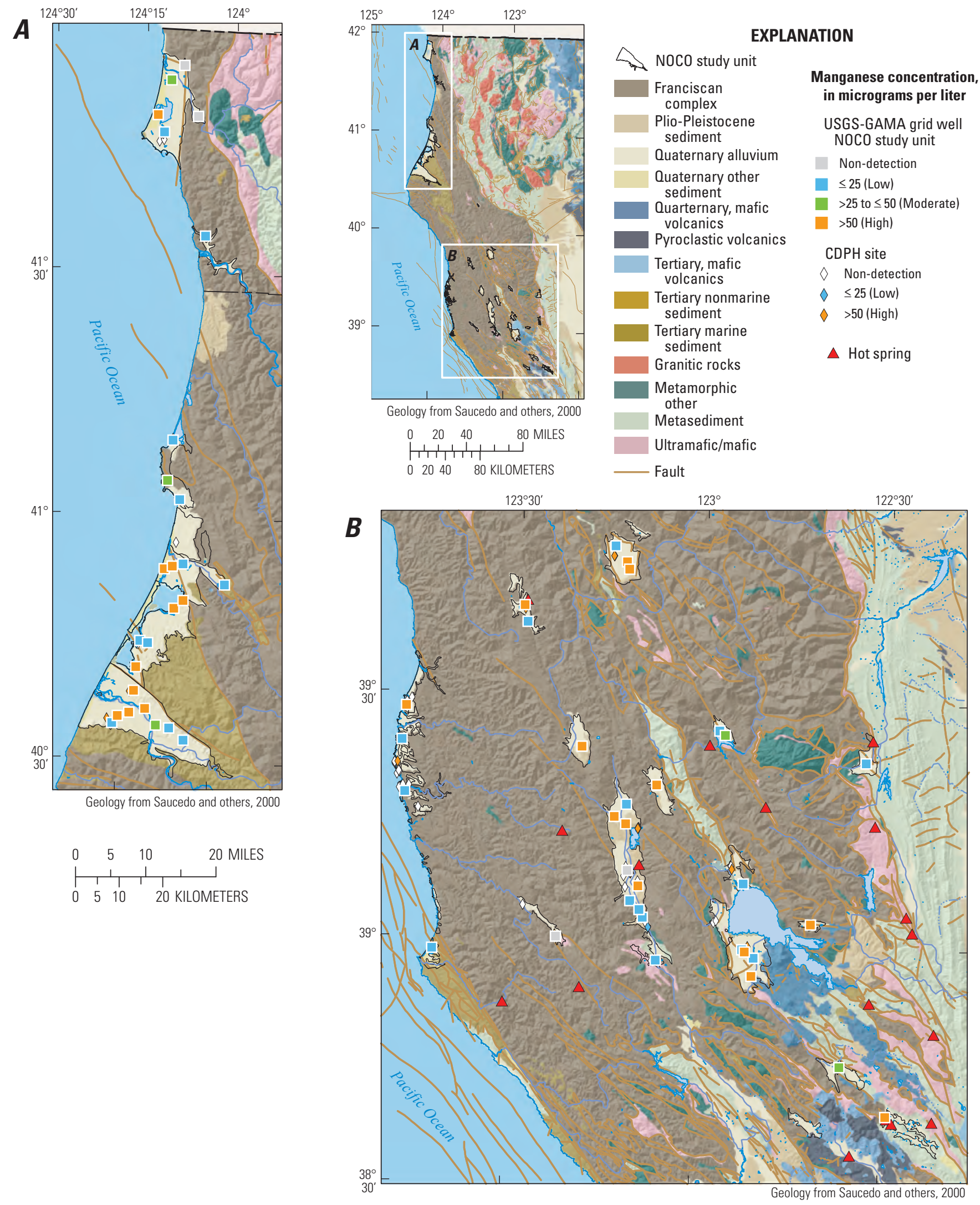

Figure 17. Relative-concentrations of manganese in USGS-GAMA grid sites and CDPH sites for the period June 1, 2006-June 1, 2009, from the CDPH water-quality database in the $(A)$ Coastal Basins study area and $(B)$ Interior Basins study area, Northern Coast Ranges study unit, 2009, California GAMA Priority Basin Project. 
depth to top-of-perforations (table 9). Iron and manganese concentrations were negatively correlated with DO (table 9), with significantly higher iron and manganese concentrations in groundwater with anoxic compared with oxic conditions (table 6). This suggests reductive dissolution from aquifer sediments as the primary process for mobilizing iron and manganese into the groundwater.

\section{Organic Constituents with Health-Based Benchmarks}

The organic constituents with health-based benchmarks assessed in this study are volatile organic compounds (VOCs) and pesticides and pesticide degradates. VOCs may be present in paints, solvents, fuels, refrigerants, and fumigants, and may be formed as byproducts of water disinfection.
VOCs are characterized by a volatile nature, or tendency to evaporate, and they generally persist longer in groundwater than in surface water because groundwater is isolated from the atmosphere. Pesticides and pesticide degradates are used to control weeds, fungi, or insects in agricultural, urban, and suburban settings. Of the 168 organic constituents analyzed, 11 were detected at 1 or more USGS-GAMA grid sites. Of these 11 constituents, 10 have health-based benchmarks (table 2).

Four organic constituents with health-based benchmarks were identified for additional evaluation in the status assessment because they were detected at moderate or high relative-concentrations or detected in 10 percent or more of the USGS-GAMA grid sites: the VOCs chloroform, vinyl chloride, and methyl tert-butyl ether (MTBE) and the pesticide simazine (figs. 10, 18, 19; tables 3, 7).

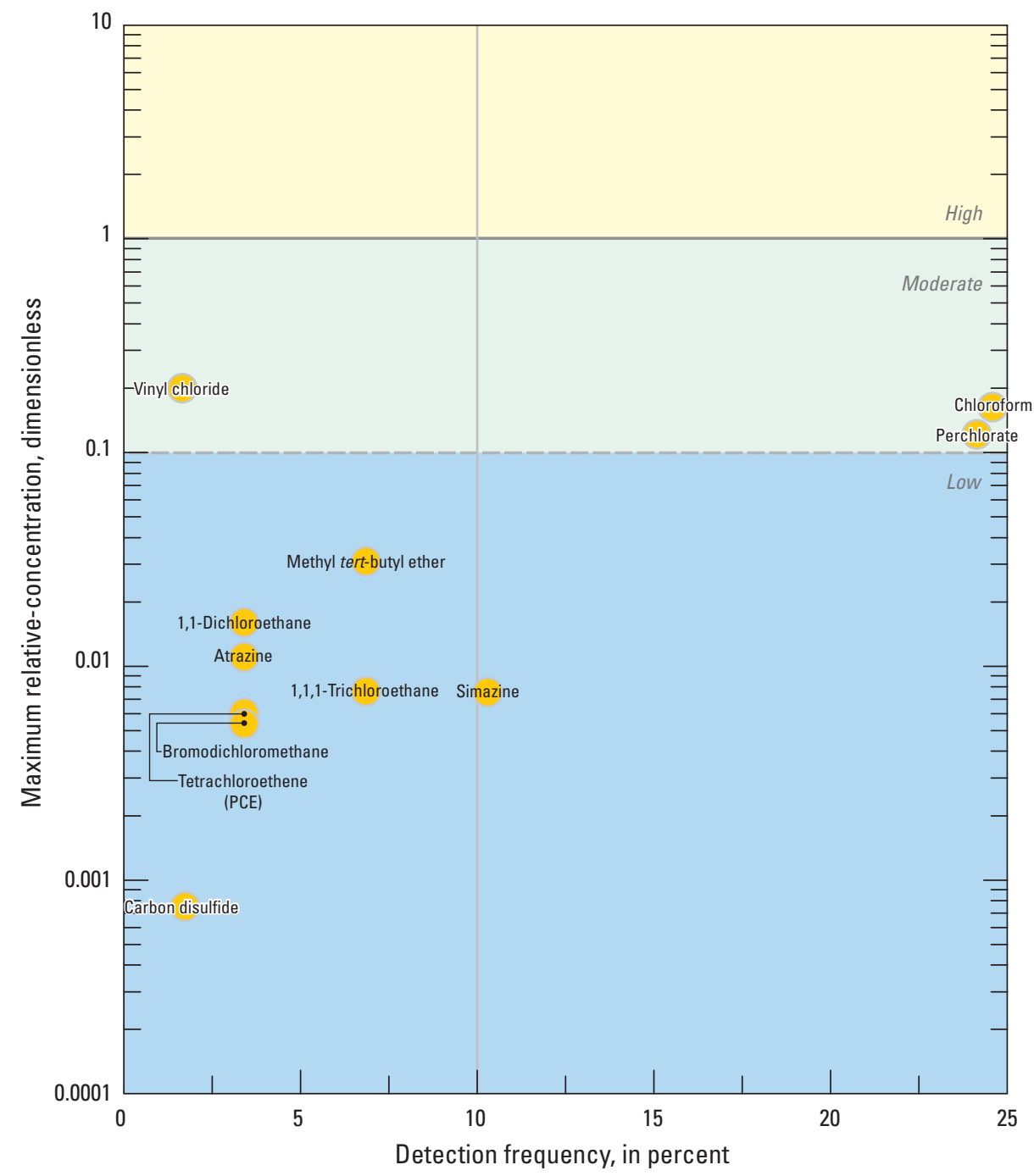

Figure 18. Maximum relative-concentration of organic and special-interest constituents detected in USGS-GAMA grid sites, Northern Coast Ranges study unit, 2009, California GAMA Priority Basin Project. [NOCO-IN, Interior Basins study area; NOCO-CO, Coastal Basins study area] 
$\boldsymbol{A}$

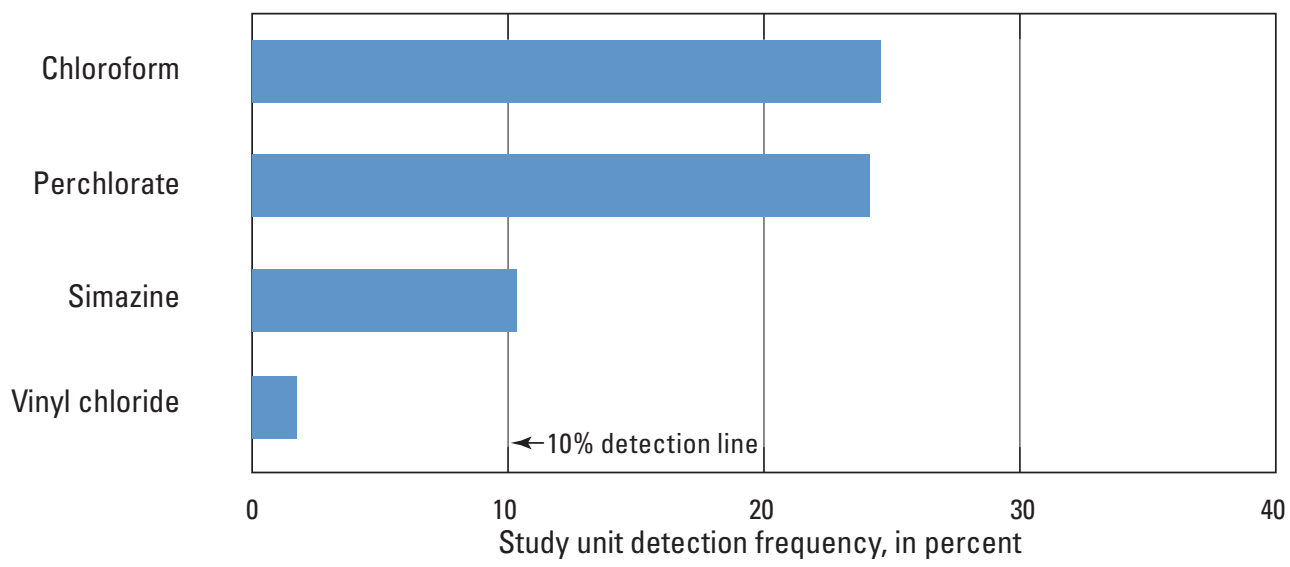

B

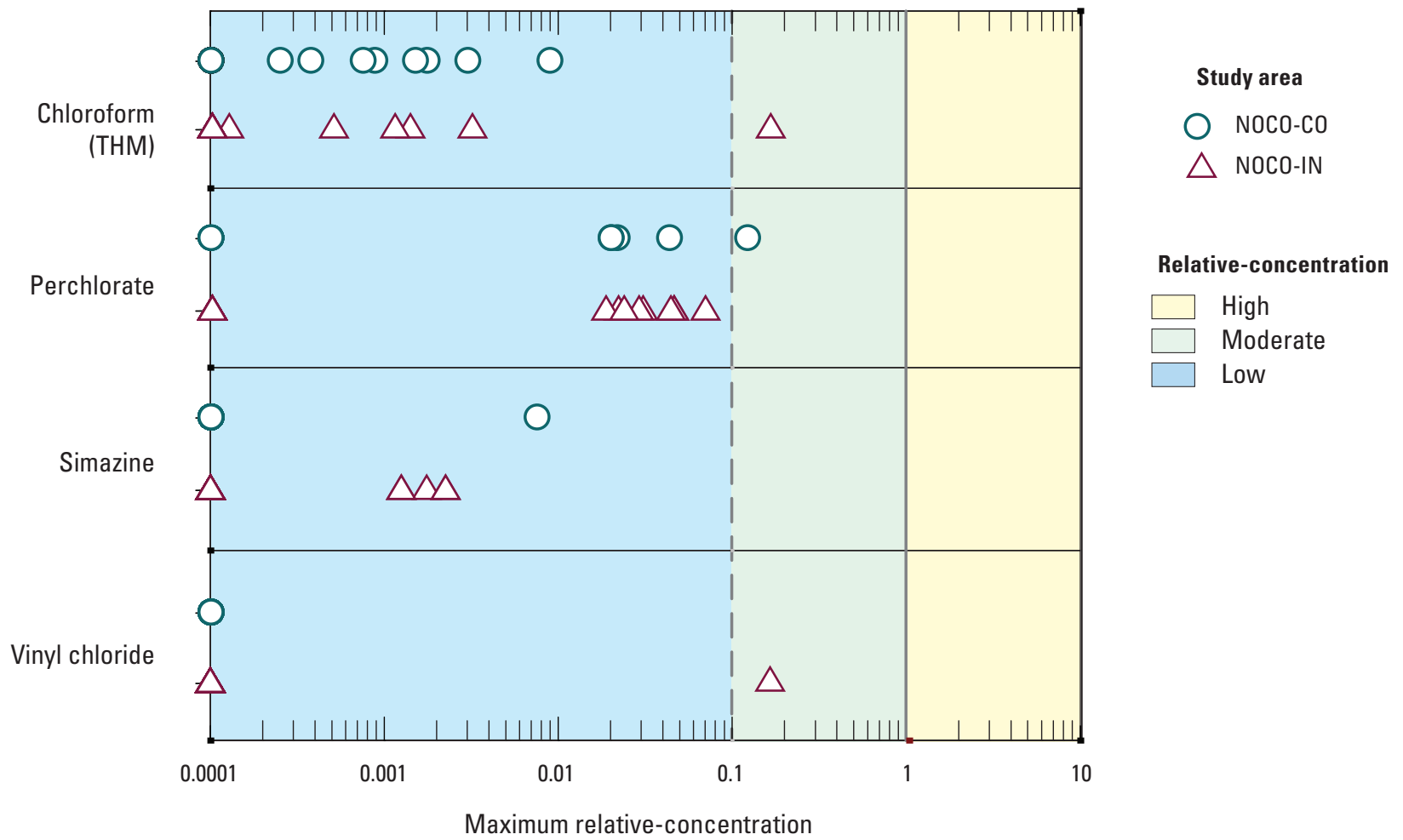

Figure 19. (A) Detection frequency and $(B)$ maximum relative-concentration of organic and special-interest constituents detected in USGS-GAMA grid sites, Northern Coast Ranges study unit, 2009, California GAMA Priority Basin Project. [NOCO-IN, Interior Basins study area; NOCO-CO, Coastal Basins study area] 
Organic constituents with health-based benchmarks, as a group, were detected at high relative-concentrations in 0.2 percent (spatially weighted) of the primary aquifer system, at moderate relative-concentrations in 1.7 percent, and at low relative-concentrations in 39.7 percent. Organic constituents were not detected in 58.4 percent of the primary aquifer system (table 8B).

\section{Volative Organic Compounds}

VOCs, as a class, were detected at high relativeconcentrations in 0.2 percent (spatially weighted) of the primary aquifer system, at moderate relative-concentrations in 1.7 percent, and at low relative-concentrations in 36.2 percent. VOCs were not detected in 61.9 percent of the primary aquifer system (table 8B). The gasoline component MTBE was detected at high relative-concentrations at one CDPH site during the current period of study. The trihalomethane chloroform and the organic synthesis reagent vinyl chloride were detected at moderate relative-concentrations in one grid site in the NOCO-IN study area (figs. 10, 19B; table C1).

Solvents are used for a variety of industrial, commercial, and domestic purposes (Zogorski and others, 2006).

Historically, chlorinated solvents have had a wide variety of applications, including dry cleaning, vapor degreasing of metal parts, hand cleaning of metal parts, paint stripping, fire extinguishers, adhesives, lubricants, and silicones (Petrisor and Wells, 2008). No solvents were detected at high or moderate relative-concentrations in the primary aquifer system (table 8B). Solvents were detected at low relativeconcentrations in 8.6 percent of the primary aquifer system. Solvents were not detected in 91.4 percent of the primary aquifer system.

Organic synthesis reagents are compounds used in the manufacture or preparation of organic compounds. Organic compounds (such as vinyl chloride) are commonly used to make polyvinyl chloride (PVC) pipes. PVC pipes are regularly used in drinking-water systems, and organic synthesis reagents are commonly released from the PVC pipes into the water system (U.S. Environmental Protection Agency, 2013). No organic synthesis reagents were detected at high relativeconcentrations in the primary aquifer system (table 8B). One organic synthesis reagent (vinyl chloride) was detected at moderate relative-concentrations in 1.7 percent of the primary aquifer system (fig. 18). Organic synthesis reagents were not detected in 98.3 percent of the primary aquifer system (table 8B).

Gasoline components include gasoline hydrocarbons and oxygenates. Gasoline hydrocarbons are straight, branched, or cyclic-structured VOCs containing only carbon and hydrogen atoms and are common ingredients in gasoline and other petroleum product formulations. Gasoline oxygenates are compounds that contain oxygen and are added to gasoline to increase the efficiency of combustion in order to meet the requirements of the 1990 Clean Air Act Amendments (Zogorski and others, 2006). Gasoline components were detected at high relative-concentrations in 0.2 percent (spatially weighted) of the primary aquifer system (table 8B). The gasoline component detected at high relativeconcentration was the gasoline oxygenate MTBE. MTBE was also detected at low relative-concentrations in 6.9 percent of the primary aquifer system (fig. 18). Gasoline components were not detected in 92.9 percent of the primary aquifer system (table 8B).

Water used for drinking water and other household uses in domestic and municipal systems commonly is disinfected with chlorine solutions. As a side effect to disinfecting the water, the chlorine may react with natural organic matter to produce trihalomethanes (THMs) and other chlorinated and (or) brominated disinfection byproducts. No THMs were detected at high relative-concentrations in the primary aquifer system of the NOCO study unit. THMs were detected at moderate relative-concentrations in 1.7 percent of the primary aquifer system and at low relative-concentrations in 22.4 percent. THMs were not detected in 75.9 percent of the primary aquifer system (table 8B). 

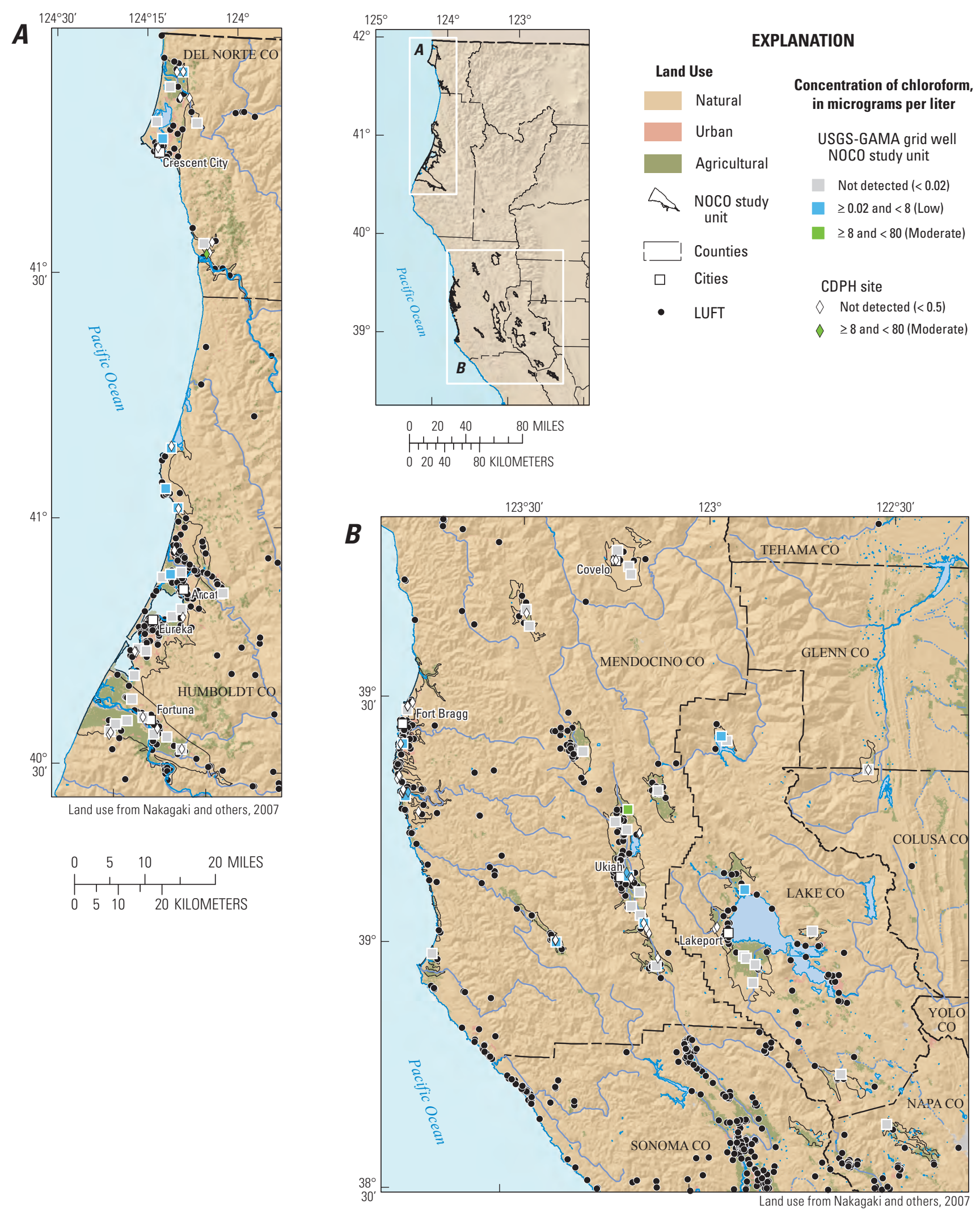

Figure 20. Relative-concentrations of chloroform detected in USGS-GAMA grid sites and CDPH sites for the period June 1, 2006June 1, 2009, from the CDPH water-quality database, and locations of leaking or formerly leaking underground fuel tanks (LUFTs), Northern Coast Ranges study unit, 2009, California GAMA Priority Basin Project. [NOCO-IN, Interior Basins study area; NOCO-C0, Coastal Basins study area] 


\section{Understanding Assessment for Chloroform}

Chloroform has been widely detected in national, regional, and local studies of VOCs in ground, surface, source, and drinking waters (Ivahnenko and Barbash, 2004). Additionally, chloroform was the most frequently detected VOC in groundwater nationwide in studies conducted by the USGS NAWQA Program (Zogorski and others, 2006). Chloroform was detected in the NOCO study unit at a high relative-concentration in the $\mathrm{CDPH}$ water-quality database prior to June 1, 2006, but was not detected at high relativeconcentrations during the current period of study (fig. 20). Chloroform was detected in 24 percent of the primary aquifer system (figs. 10, 18, 19).

Chloroform concentrations were significantly negatively correlated with well depth and depth to top-of-perforations (table 9). Seven of the 14 sites in which chloroform was detected had depths $<70 \mathrm{ft}$ bls. Thirteen of these sites had depth to top-of-perforation information available, and all had depths to top-of-perforations $\leq 70 \mathrm{ft}$ bls (fig. 21). Chloroform concentrations were positively correlated with DO (table 9) and were significantly higher in groundwater with oxic compared with anoxic conditions (table 6). Thirteen of the 14 sites in which chloroform was detected had oxic groundwater conditions. Chloroform concentrations also were significantly greater in sites with groundwater classified as modern age than in sites with mixed ages (table 6). This result was expected because chloroform concentrations and DO also were significantly correlated. Chloroform concentrations had a negative correlation with $\mathrm{pH}$ (table 9), and this relation is likely caused by the positive correlations between $\mathrm{pH}$ and well depth and depth to top-of-perforations (table 5). In summary, most sites containing chloroform have depth to top-ofperforations $\leq 70 \mathrm{ft}$ bls with oxic, modern-age groundwater.

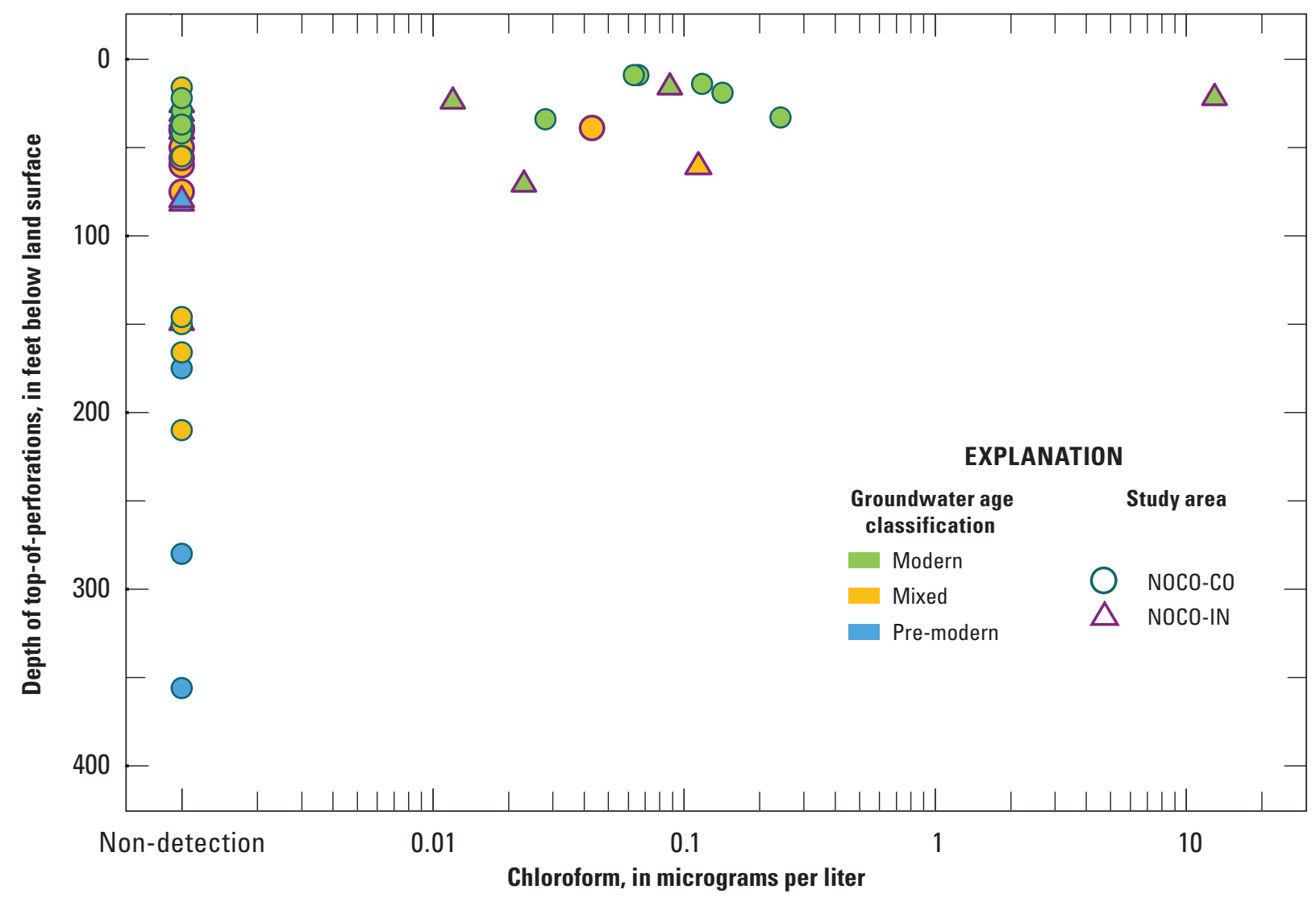

Figure 21. Trihalomethane chloroform concentrations relative to groundwater age classification and depth to top-of-perforations in USGS-GAMA grid sites sampled for the Northern Coast Ranges study unit, 2009, California GAMA Priority Basin Project. 

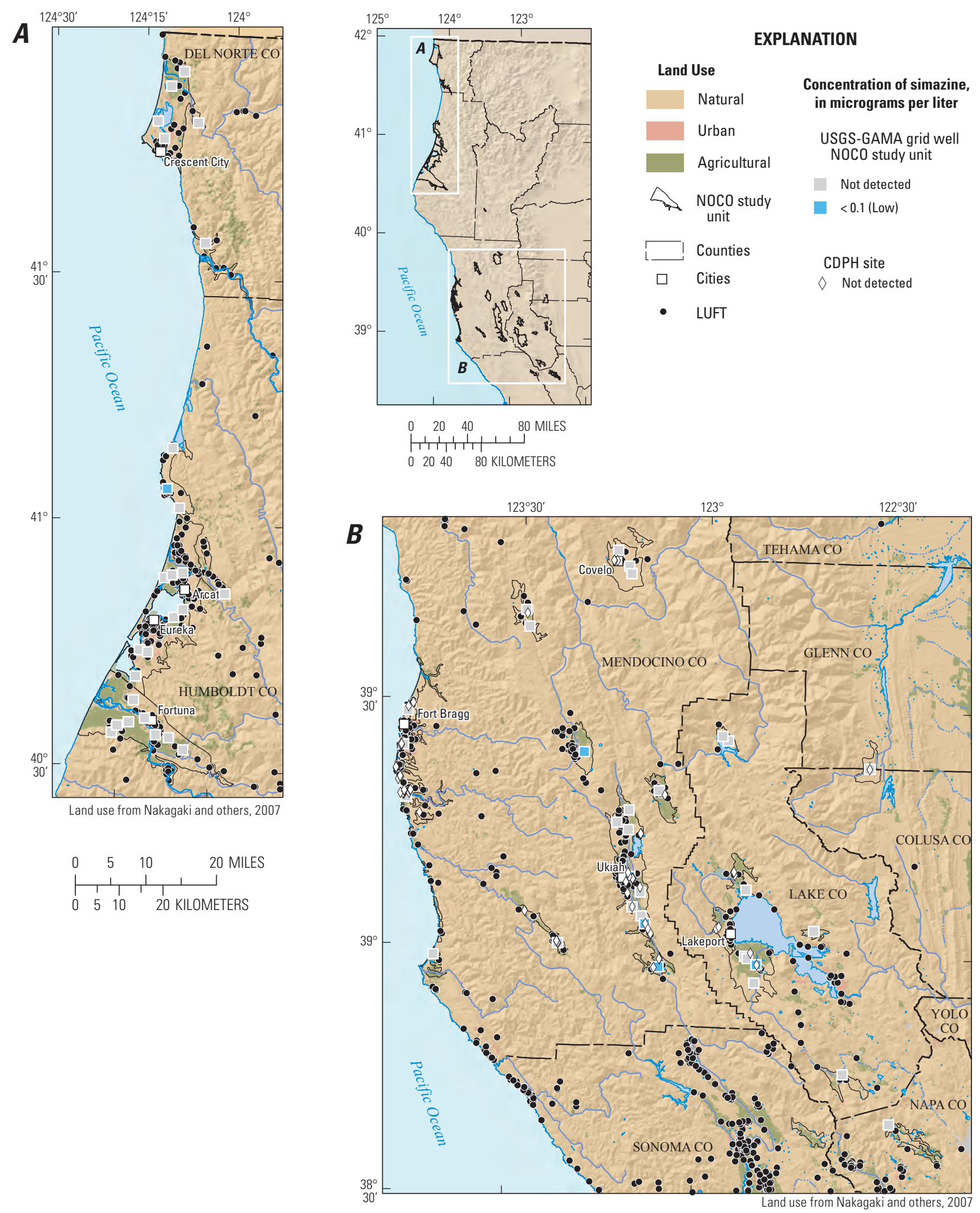

Figure 22. Relative-concentrations of simazine detected in USGS-GAMA grid sites and CDPH sites for the period June 1, 2006June 1, 2009, from the CDPH water-quality database, and locations of leaking or formerly leaking underground fuel tanks (LUFTs), Northern Coast Ranges study unit, 2009, California GAMA Priority Basin Project. [NOCO-IN, Interior Basins study area; NOCO-CO, Coastal Basins study area] 


\section{Pesticides and Pesticide Degradates}

Pesticides and pesticide degradates include herbicides, insecticides, and fungicides and are used in agricultural applications on orchards and vineyards and in urban settings for weed control (Gilliom and others, 2006). Pesticides and pesticide degradates, as a class, were detected at low relativeconcentrations in 10.3 percent of the primary aquifer system and not detected in 89.7 percent of the primary aquifer system (table 8B). No pesticides or pesticide degradates were detected at high or moderate relative-concentrations in the primary aquifer system.

\section{Understanding Assessment for Simazine}

Simazine was the most frequently detected triazine herbicide in groundwater in California (Troiano and others, 2001). In addition, simazine was among the most commonly detected herbicides in groundwater in major aquifers across the United States (Gilliom and others, 2006). Simazine was detected in 10.3 percent of the primary aquifer system (figs. 18, 19, 22).

Simazine was detected at six wells with depths and depths to the top-of-perforations of $\leq 70 \mathrm{ft}$ bls (fig. 23; one of these wells was not plotted on figure 23 , due to the lack of depth to the top-of-perforation information), and five of these wells also had depths of $<70 \mathrm{ft}$ bls. All six simazine detections occurred in sites with groundwater classified as modern age (fig. 23), so it is not surprising that simazine concentrations were significantly higher at sites with modern groundwater than at sites with mixed-age groundwater (table 6).

Simazine concentrations were greater in groundwater with oxic redox conditions than in groundwater with anoxic conditions (table 6). Five simazine detections were from sites having groundwater classified as oxic, and one detection was from a site with groundwater with mixed redox conditions. In summary, most sites containing simazine may be characterized as shallow ( $<70 \mathrm{ft}$ bls), with depth to top-of-perforations $\leq 70 \mathrm{ft}$ bls and oxic, modern-age groundwater.

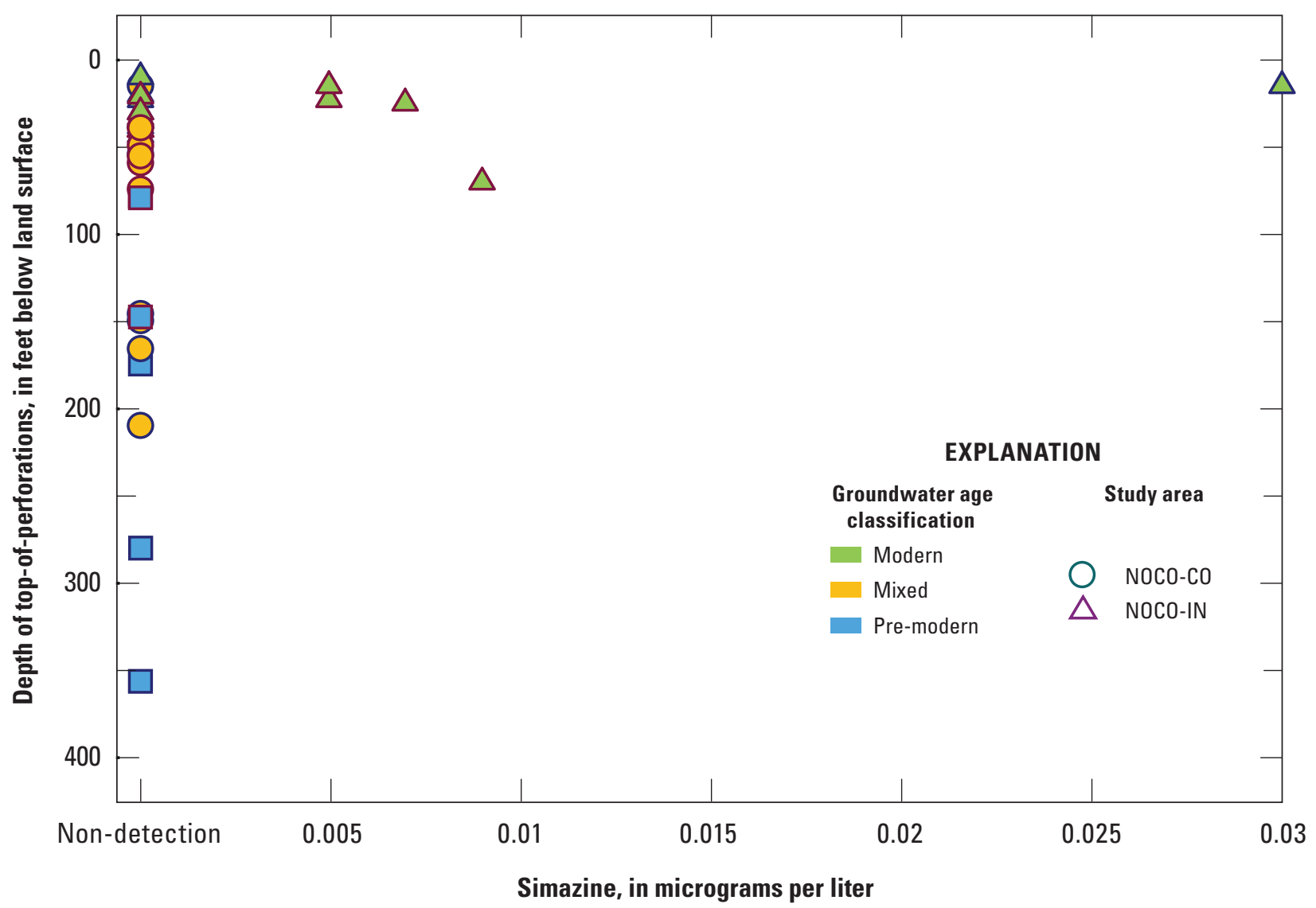

Figure 23. The herbicide simazine concentrations relative to groundwater age classification and depth to top-of-perforations in USGS-GAMA grid sites sampled for the Northern Coast Ranges study unit, 2009, California GAMA Priority Basin Project. 

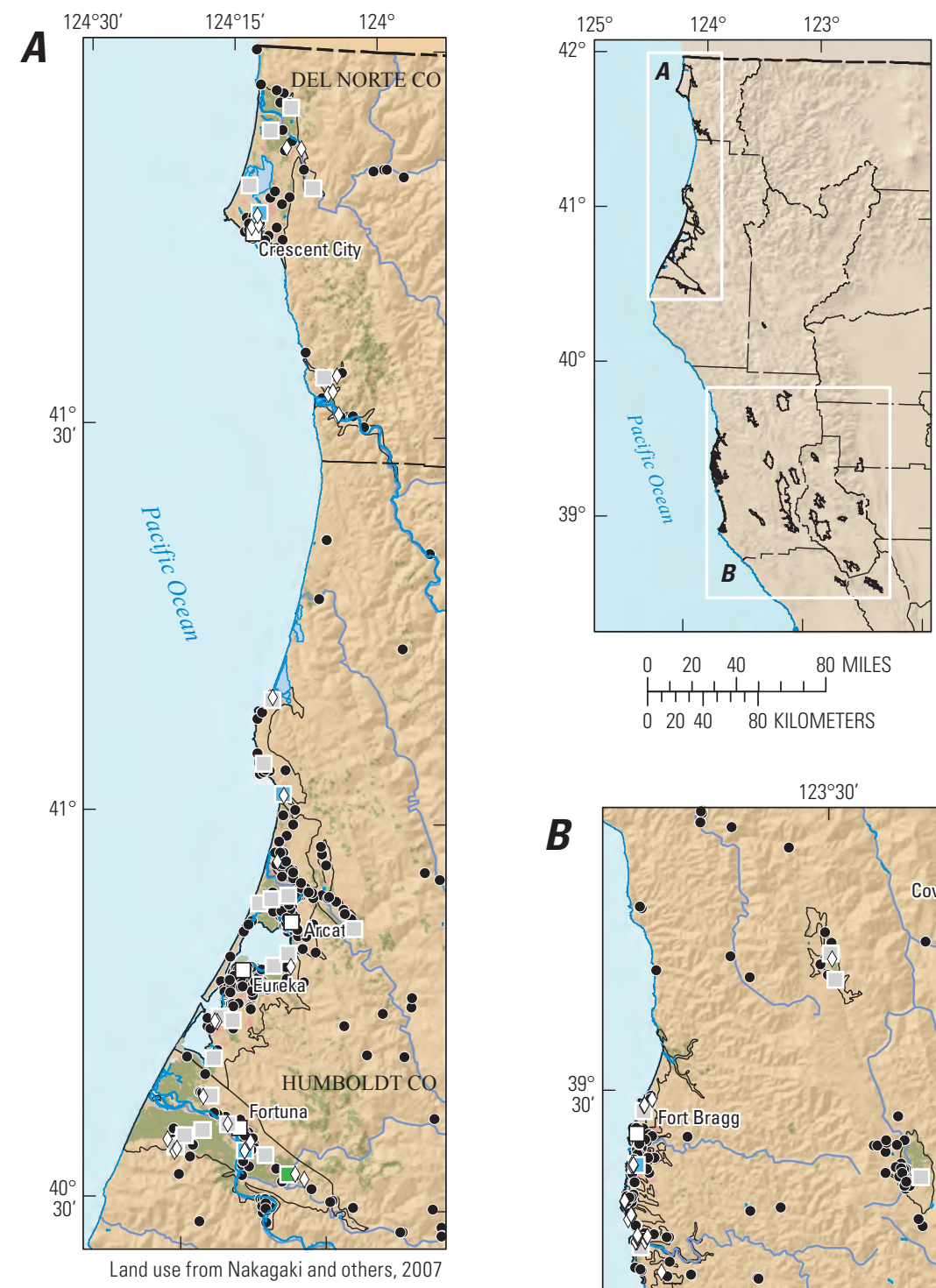

\section{EXPLANATION}

$\begin{array}{lc}\begin{array}{l}\text { Land Use } \\ \text { Urban }\end{array} & \begin{array}{r}\text { Concentration of perchlorate, } \\ \text { in micrograms per liter } \\ \text { USGS-GAMA grid well } \\ \text { NOCO study unit }\end{array} \\ \text { Agricultural } & \text { Not detected }(<0.1) \\ \text { NOCO study } & >0.1 \text { and }<0.6 \text { (Low) } \\ \text { unit } & >0.6 \text { and }<6 \text { (Moderate) }\end{array}$

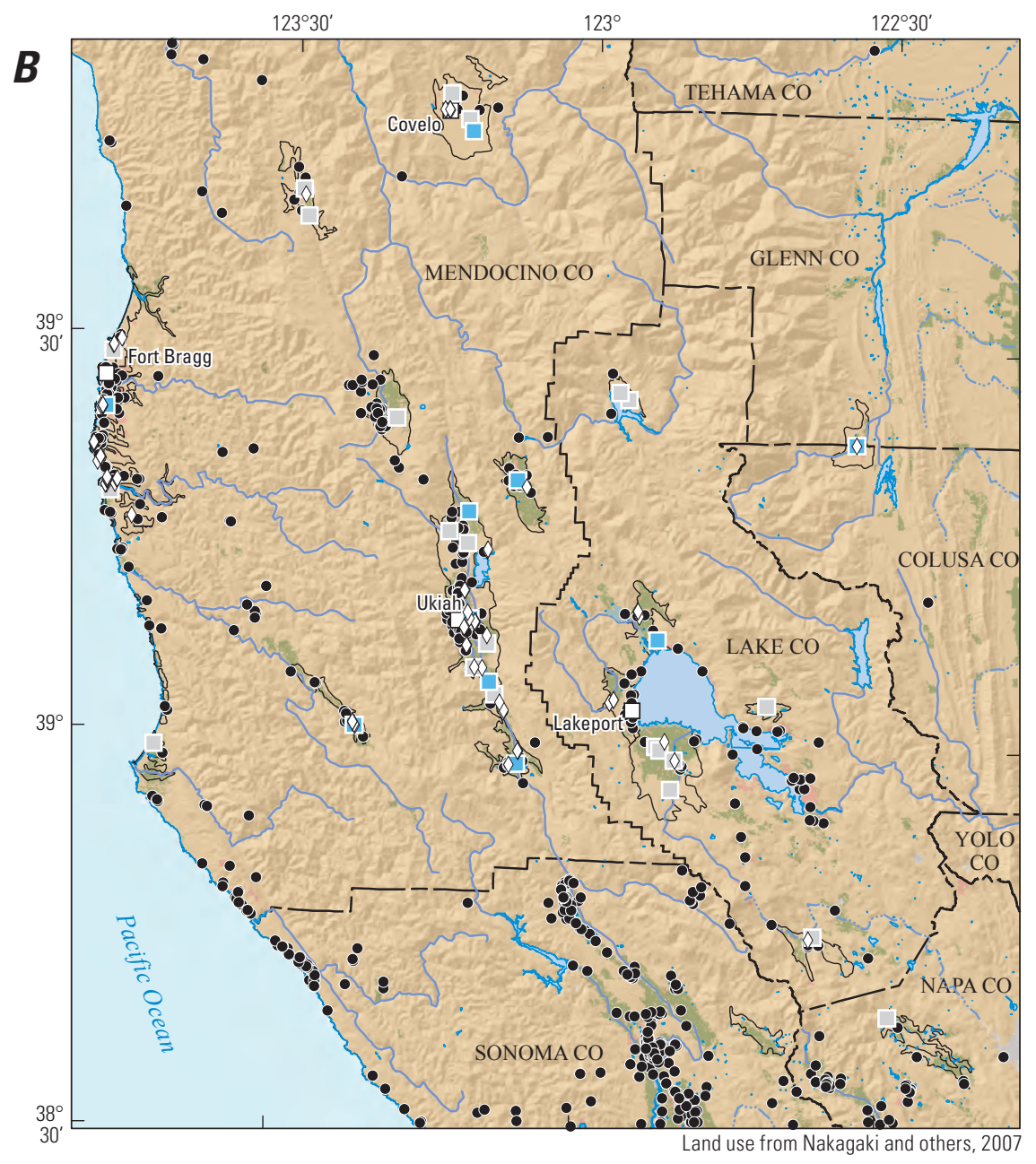

Figure 24. Relative-concentrations of perchlorate in USGS-GAMA grid sites and CDPH sites for the period June 1, 2006-June 1, 2009, from the CDPH water-quality database, and land use, Northern Coast Ranges study unit, 2009, California GAMA Priority Basin Project. 


\section{Special-Interest Constituent with Health-Based Benchmark}

Perchlorate was considered a special-interest constituent at the inception of the GAMA-PBP because it had recently been detected in some drinking-water supplies in California and the CDPH was evaluating whether or not an MCL-CA was warranted (California Department of Public Health, 2008). An MCL-CA of $6 \mu \mathrm{g} / \mathrm{L}$ was established in 2007. Perchlorate was not detected at high relative-concentrations in the primary aquifer system in the NOCO study unit (fig. 24). Perchlorate was detected at moderate relative-concentrations in 1.7 percent of the primary aquifer system and at low relativeconcentrations in 22.4 percent (table 8B). Perchlorate was not detected in 75.9 percent of the primary aquifer system.

\section{Understanding Assessment for Perchlorate}

Potential sources of perchlorate to groundwater can be natural or anthropogenic. Perchlorate is formed naturally in the atmosphere, and very low concentrations are found in precipitation (Dasgupta and others, 2005; Parker and others, 2008; Rajagopalan and others, 2009). The distribution of perchlorate under natural conditions in groundwater is likely correlated with climate because the extent of evaporative concentration of precipitation in the hydrologic cycle is likely to increase with increasing aridity (Fram and Belitz, 2011). Perchlorate salts accumulate in unsaturated zones and soils (Rao and others, 2007). Most of the known sites of anthropogenic contamination of groundwater with perchlorate are associated with facilities that manufacture or use solid rocket fuels; other anthropogenic sources include military munitions storage, use, and disposal, and manufacturing and disposal of pyrotechnics, safety flares, and explosives (Parker and others, 2008). Potential agricultural sources include the Chilean nitrate fertilizer applied extensively in the early to mid-1900s (Dasgupta and others, 2005). Irrigation can also be considered an agricultural source if it redistributes perchlorate salts that were originally naturally present in the unsaturated zone (Fram and Belitz, 2011).

Perchlorate concentrations were significantly positively correlated with percentage of agricultural land use (table 9). Agricultural land use (within 500-m-radius buffer areas around each of the sites) was the dominant land-use classification for 8 of the 14 sites in which perchlorate was detected.

Perchlorate concentrations had a significant negative correlation with depth to top-of-perforations (table 9). All 14 wells in which perchlorate was detected had depths to the top-of-perforations of $\leq 70 \mathrm{ft}$ bls (fig. 25), and 7 of these wells had well depths of $<70 \mathrm{ft}$ bls.

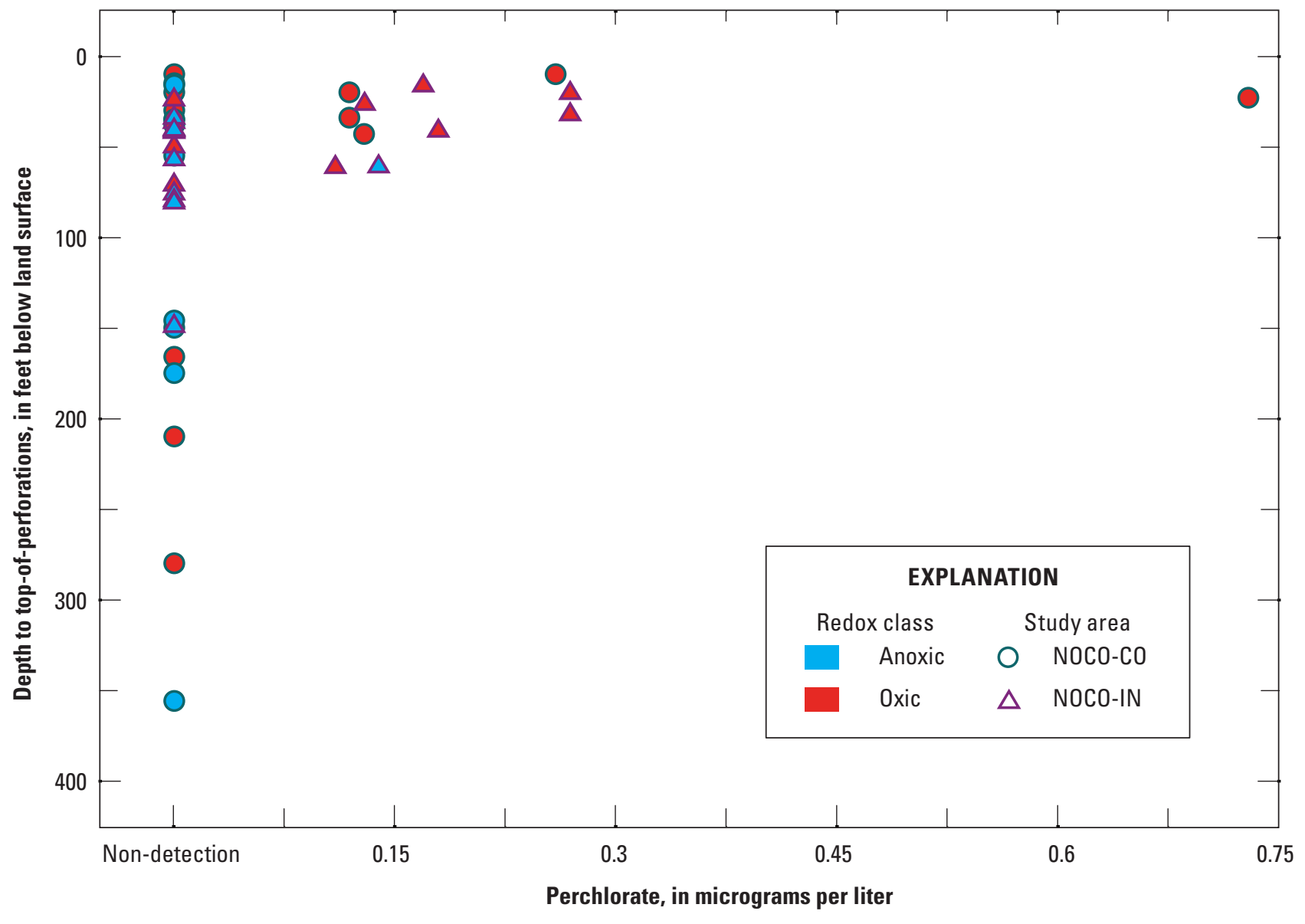

Figure 25. The special-interest constituent perchlorate concentrations relative to geochemical condition and depths to top-ofperforations in USGS-GAMA grid sites sampled for the Northern Coast Ranges study unit, 2009, California GAMA Priority Basin Project. 
Perchlorate concentrations were positively correlated with DO (table 9). Perchlorate concentrations were significantly higher in sites with oxic groundwater than in anoxic groundwater (table 6; fig. 25). While perchlorate biodegrades under anoxic conditions in some aquifers (Sturchio and others, 2007), the apparent relation between perchlorate and DO in the NOCO study unit may be a result of its occurrence predominantly in relatively shallow groundwater.

Fram and Belitz (2011) developed a model for predicting the probability of detecting perchlorate in groundwater under natural conditions as a function of climate. Although perchlorate was often detected in sites having land use classified as agricultural, the observed detection frequencies of perchlorate in the NOCO-IN and NOCO-CO study areas are close to the predicted climate-based detection probabilities, thus, the occurrence of perchlorate in the NOCO study unit is consistent with natural sources of perchlorate.

\section{Summary}

Groundwater quality in the approximately 633-squaremile (1,639-square-kilometer) Northern Coast Ranges (NOCO) study unit was investigated as part of the Priority Basin Project of the Groundwater Ambient Monitoring and Assessment (GAMA) Program and the U.S. Geological Survey (USGS) National Water-Quality Assessment (NAWQA) Program. The GAMA Northern Coast Ranges study provides a spatially unbiased characterization of untreated groundwater quality in the primary aquifer system. The assessment is based on water-quality and ancillary data collected in 2009 by the USGS from 58 sites and on data from the California Department of Public Health (CDPH) waterquality database.

The first component of this study, the status of the current quality of the groundwater resource, was assessed by using data from samples analyzed for naturally occurring inorganic constituents (such as trace elements and major and minor ions), organic constituents (volatile organic compounds [VOCs] and pesticides and pesticide degradates), and the special-interest constituent perchlorate. The status assessment characterizes the quality of groundwater resources in the primary aquifer system of the NOCO study unit, not the treated drinking water delivered to consumers by water purveyors.

Relative-concentrations (sample concentration divided by the health- or aesthetic-based benchmark concentration) were used for evaluating groundwater quality for those constituents that have Federal and (or) California regulatory or nonregulatory benchmarks for drinking-water quality.

Aquifer-scale proportion was used as the primary metric for evaluating regional-scale groundwater quality. High aquifer-scale proportion was defined as the percentage of the primary aquifer system with relative-concentration greater than (>) 1.0 for a particular constituent or class of constituents; proportion is based on an aerial rather than a volumetric basis. Moderate and low aquifer-scale proportions were defined as the percentage of the primary aquifer system with moderate and low relative-concentrations, respectively. Two statistical approaches, grid-based and spatially weighted, were used to evaluate aquifer-scale proportions for individual constituents and classes of constituents. Grid-based and spatially weighted estimates were comparable in the NOCO study unit (within 90 percent confidence intervals).

Inorganic constituents with health-based benchmarks were detected at high relative-concentrations in 10.3 percent of the primary aquifer system, moderate relative-concentrations in 13.8 percent, and low relative-concentrations in 75.9 percent. The high aquifer-scale proportion of inorganic constituents primarily reflected high aquifer-scale proportions of boron (8.6 percent), arsenic (3.4 percent), and barium (1.7 percent). The inorganic constituents with aesthetic-based benchmarksiron and manganese - were detected at high relativeconcentrations in 25.9 percent and 39.7 percent of the primary aquifer system, respectively.

Relative-concentrations of organic constituents with health-based benchmarks (one or more) were high in 0.2 percent of the primary aquifer system, moderate in 1.7 percent, and low in 39.7 percent. Organic constituents were not detected in 58.4 percent of the primary aquifer system. Of the 168 organic constituents analyzed, 11 constituents were detected. Nearly all detections were at low relative-concentrations. The VOC chloroform and the herbicide simazine were the only organic constituents detected in more than 10 percent of grid sites. The special-interest constituent perchlorate was detected at moderate relativeconcentrations in 1.7 percent of the primary aquifer system and at low relative-concentrations in 22.4 percent.

The second component of this work, the understanding assessment, used statistical correlations between concentrations of constituents and values of selected potential explanatory factors to identify the factors potentially affecting the concentrations and occurrences of constituents detected at high relative-concentrations or, for organic constituents, with detection frequencies $>10$ percent. The potential explanatory factors evaluated were land use, density of septic tanks, density of leaking (or formerly leaking) underground fuel tanks, well depth and depth to the top of the perforated interval in the well, aridity index, field water temperature, distance to nearest hot spring and geothermal well, $\mathrm{pH}$, dissolved oxygen concentration, study (geographic) area, groundwater age distribution, and redox condition.

The understanding assessment indicated that high and moderate relative-concentrations of boron primarily occurred in the Interior Basins study area and may be attributed to groundwater interacting with hydrothermal systems. High and moderate relative-concentrations of boron were associated with elevated groundwater temperatures, groundwater chemistry characteristics similar to those of geothermal waters, and proximity to known geothermal areas. Boron concentrations generally were higher where low dissolved oxygen concentrations or anoxic conditions 
exist. The understanding assessment also indicated that high and moderate relative-concentrations of arsenic occur predominantly in the Interior Basins study area under reducing conditions and possibly are enhanced by hydrothermal systems (when present).

Chloroform, simazine, and perchlorate were detected predominantly in shallow sites with depths to top-ofperforations less than or equal to 70 feet below land surface, modern groundwater, and oxic groundwater conditions.

\section{Acknowledgments}

The authors thank the following cooperators for their support: the California State Water Resources Control Board, Lawrence Livermore National Laboratory, California Department of Public Health, and California Department of Water Resources. We especially thank the site owners and water purveyors for their cooperation and generosity in allowing the U.S. Geological Survey to collect samples from their sites. Funding for this work was provided by State of California bonds authorized by Proposition 50 and administered by the California State Water Resources Control Board.

\section{References}

Ballantyne, J.M., and Moore, J.N., 1988, Arsenic geochemistry in geothermal systems: Geochimica et Cosmochimica Acta, v. 52, no. 2, p. 475-483. (Also available at http://dx.doi.org/ 10.1016/0016-7037(88)90102-0.)

Belitz, Kenneth, Dubrovsky, N.M., Burow, Karen, Jurgens, Bryant, and Johnson, Tyler, 2003, Framework for a ground-water quality monitoring and assessment program for California: U.S. Geological Survey Water-Resources Investigations Report 03-4166, 78 p. (Also available at http://pubs.usgs.gov/wri/wri034166/.)

Belitz, Kenneth, Jurgens, Bryant, Landon, M.K., Fram, M.S., and Johnson, Tyler, 2010, Estimation of aquifer scale proportion using equal area grids-Assessment of regional scale groundwater quality: Water Resources Research, v. 46, no. 11 , citation number W11550, 14 p. (Also available at http://dx.doi.org/10.1029/2010WR009321.)

Bennett, G.L., V, Fram, M.S., Belitz, Kenneth, and Jurgens, B.C., 2010, Status and understanding of groundwater quality in the Northern San Joaquin Basin, 2005California GAMA Priority Basin Project: U.S. Geological Survey Scientific Investigations Report 2010-5175, 82 p. (Also available at http://pubs.usgs.gov/sir/2010/5175/.)
Berkstresser, C.F., Jr., 1968, Data for springs in the Northern Coast Ranges and Klamath Mountains of California: U.S. Geological Survey Open-File Report 68-9, 49 p. (Also available at http://pubs.er.usgs.gov/publication/ofr689.)

Brown, L.D., Cai, T.T., and Dasgupta, Anirban, 2001, Interval estimation for a binomial proportion: Statistical Science, v. 16, no. 2, p. 101-117, accessed September 25, 2014, at http://www.jstor.org/stable/2676784.

Burton, C.A., Montrella, Joseph, Landon, M.K., and Belitz, Kenneth, 2011, Status and understanding of groundwater quality in the Santa Clara River Valley, 2007-California GAMA Priority Basin Project: U.S. Geological Survey Scientific Investigations Report 2011-5052, 86 p. (Also available at http://pubs.usgs.gov/sir/2011/5052/.)

California Department of Conservation, 2013, Division of Oil, Gas, and Geothermal Resources Well Finder, Geothermal Resources, Geothermal Field Maps, District 3, accessed May 2, 2014, at http://www.conservation.ca.gov/dog/ geothermal/maps/Pages/Index.aspx.

California Department of Public Health, 2006, California Code of Regulation, Title 22; Division 4, Environmental Health; Chapter 15, Domestic water quality and monitoring regulations; Article 16, Secondary water standards, accessed January 12, 2011, at http://www.cdph.ca.gov/certlic/ drinkingwater/Documents/Recentlyadoptedregulations/R21-03-finalregtext.pdf.

California Department of Public Health, 2008, Maximum contaminant levels and regulatory dates for drinking water, U.S. EPA vs. California, November 2008, accessed January 12, 2011, at http://www.cdph.ca.gov/ certlic/drinkingwater/Documents/DWdocuments/ EPAandCDPH-11-28-2008.pdf.

California Department of Public Health, 2010, Drinking water notification levels and response levels-An overview: California Department of Public Health Drinking Water Program, accessed January 12, 2011, at http://www.cdph. ca.gov/certlic/drinkingwater/Documents/Notificationlevels/ notificationlevels.pdf.

California Department of Public Health, 2013, Title 22 Code of Regulations, Division 4, Environmental health; Chapter 15, Domestic water quality and monitoring regulations; Article 3, Primary standards - bacteriological quality; §64426.1, Total coliform maximum contaminant level (MCL), accessed January 16, 2013, at http://www. cdph.ca.gov/certlic/drinkingwater/Documents/Lawbook/ dwregulations-2013-07-01.pdf.

California Department of Water Resources, 1987, Smith River Plain Ground Water Study, Sacramento: California Department of Water Resources, Northern District, Report No. 7, 147 p. 
California Department of Water Resources, 2003, California's groundwater: California Department of Water Resources Bulletin 118, update 2003, 246 p., accessed August 2, 2011, at http://www.water.ca.gov/groundwater/bulletin118/ update2003.cfm.

California Department of Water Resources, 2004a, California's groundwater-Individual basin descriptions-Sacramento River Hydrologic Region, Upper Lake Groundwater Basin: California Department of Water Resources Bulletin 118, accessed August 2, 2011, at http://www.water.ca.gov/pubs/ groundwater/bulletin_118/basindescriptions/5-13.pdf.

California Department of Water Resources, 2004b, California's groundwater-Individual basin descriptionsSacramento River Hydrologic Region, Big Valley Groundwater Basin: California Department of Water Resources Bulletin 118, accessed August 2, 2011, at http://www.water.ca.gov/pubs/groundwater/bulletin_118/ basindescriptions/5-15.pdf.

California Department of Water Resources, 2004c, California's groundwater-Individual basin descriptions - Sacramento River Hydrologic Region, Long Valley Groundwater Basin: California Department of Water Resources Bulletin 118, accessed August 2, 2011, at http://www.water.ca.gov/pubs/ groundwater/bulletin_118/basindescriptions/5-31.pdf.

California Department of Water Resources, 2004d, California's groundwater - Individual basin descriptionsSacramento River Hydrologic Region, Pope Valley Groundwater Basin: California Department of Water Resources Bulletin 118, accessed August 2, 2011, at http://www.water.ca.gov/pubs/groundwater/bulletin_118/ basindescriptions/5-68.pdf.

California Department of Water Resources, 2004e, California's groundwater-Individual basin descriptions-Sacramento River Hydrologic Region, Scotts Valley Groundwater Basin: California Department of Water Resources Bulletin 118, accessed August 2, 2011, at http://www.water.ca.gov/pubs/ groundwater/bulletin 118/basindescriptions/5-14.pdf.

California Department of Water Resources, 2004f, California's groundwater-Individual basin descriptions - Sacramento River Hydrologic Region, High Valley Groundwater Basin: California Department of Water Resources Bulletin 118, accessed August 2, 2011, at http://www.water.ca.gov/pubs/ groundwater/bulletin_118/basindescriptions/5-16.pdf.

California Department of Water Resources, 2004g, California's groundwater-Individual basin descriptionsSacramento River Hydrologic Region, Coyote Valley Groundwater Basin: California Department of Water Resources Bulletin 118, accessed August 2, 2011, at http://www.water.ca.gov/pubs/groundwater/bulletin_118/ basindescriptions/5-18.pdf.
California Department of Water Resources, 2004h, California's groundwater-Individual basin descriptionsSacramento River Hydrologic Region, Collayomi Groundwater Basin: California Department of Water Resources Bulletin 118, accessed August 2, 2011, at http://www.water.ca.gov/pubs/groundwater/bulletin_118/ basindescriptions/5-19.pdf.

California Department of Water Resources, 2004i, California's groundwater-Individual basin descriptionsSacramento River Hydrologic Region, Stonyford Town Area Groundwater Basin: California Department of Water Resources Bulletin 118, accessed August 2, 2011, at http://www.water.ca.gov/pubs/groundwater/bulletin_118/ basindescriptions/5-63.pdf.

California Department of Water Resources, 2004j, California's groundwater - Individual basin descriptions - Sacramento River Hydrologic Region, North Fork Cache Creek Groundwater Basin: California Department of Water Resources Bulletin 118, accessed August 2, 2011, at http://www.water.ca.gov/pubs/groundwater/bulletin 118/ basindescriptions/5-93.pdf.

California Department of Water Resources, 2004k, California's groundwater-Individual basin descriptionsSacramento River Hydrologic Region, Middle Creek Groundwater Basin: California Department of Water Resources Bulletin 118, accessed August 2, 2011, at http://www.water.ca.gov/pubs/groundwater/bulletin_118/ basindescriptions/5-94.pdf.

California Department of Water Resources, 20041, California's groundwater-Individual basin descriptionsNorth Coast Hydrologic Region, Covelo Round Valley Groundwater Basin: California Department of Water Resources Bulletin 118, accessed August 2, 2011, at http://www.water.ca.gov/pubs/groundwater/bulletin 118/ basindescriptions/1-11.pdf.

California Department of Water Resources, 2004m, California's groundwater-Individual basin descriptionsNorth Coast Hydrologic Region, Laytonville Valley Groundwater Basin: California Department of Water Resources Bulletin 118, accessed August 2, 2011, at http://www.water.ca.gov/pubs/groundwater/bulletin_118/ basindescriptions/1-12.pdf.

California Department of Water Resources, 2004n, California's groundwater-Individual basin descriptionsNorth Coast Hydrologic Region, Little Lake Valley Groundwater Basin: California Department of Water Resources Bulletin 118, accessed August 2, 2011, at http://www.water.ca.gov/pubs/groundwater/bulletin 118/ basindescriptions/1-13.pdf. 
California Department of Water Resources, 2004o, California's groundwater-Individual basin descriptionsNorth Coast Hydrologic Region, Anderson Valley Groundwater Basin: California Department of Water Resources Bulletin 118, accessed August 2, 2011, at http://www.water.ca.gov/pubs/groundwater/bulletin 118/ basindescriptions/1-19.pdf.

California Department of Water Resources, 2004p, California's groundwater-Individual basin descriptionsNorth Coast Hydrologic Region, Garcia River Valley Groundwater Basin: California Department of Water Resources Bulletin 118, accessed August 2, 2011, at http://www.water.ca.gov/pubs/groundwater/bulletin_118/ basindescriptions/1-20.pdf.

California Department of Water Resources, 2004q, California's groundwater-Individual basin descriptionsNorth Coast Hydrologic Region, Hettenshaw Valley Groundwater Basin: California Department of Water Resources Bulletin 118, accessed August 2, 2011, at http://www.water.ca.gov/pubs/groundwater/bulletin 118/ basindescriptions/1-36.pdf.

California Department of Water Resources, 2004r, California's groundwater - Individual basin descriptions - North Coast Hydrologic Region, Lower Laytonville Valley Groundwater Basin: California Department of Water Resources Bulletin 118, accessed August 2, 2011, at http://www.water.ca.gov/pubs/groundwater/bulletin_118/ basindescriptions/1-38.pdf.

California Department of Water Resources, 2004s, California's groundwater-Individual basin descriptions - North Coast Hydrologic Region, Williams Valley Groundwater Basin: California Department of Water Resources Bulletin 118, accessed August 2, 2011, at http://www.water.ca.gov/pubs/ groundwater/bulletin_118/basindescriptions/1-43.pdf.

California Department of Water Resources, 2004t, California's groundwater - Individual basin descriptions - North Coast Hydrologic Region, Gravelly Valley Groundwater Basin: California Department of Water Resources Bulletin 118, accessed August 2, 2011, at http://www.water.ca.gov/pubs/ groundwater/bulletin 118/basindescriptions/1-48.pdf.

California Department of Water Resources, 2004u, California's groundwater-Individual basin descriptions - North Coast Hydrologic Region, Potter Valley Groundwater Basin: California Department of Water Resources Bulletin 118, accessed August 2, 2011, at http://www.water.ca.gov/pubs/ groundwater/bulletin_118/basindescriptions/1-51.pdf.
California Department of Water Resources, 2004v, California's groundwater-Individual basin descriptions - North Coast Hydrologic Region, Ukiah Valley Groundwater Basin: California Department of Water Resources Bulletin 118, accessed August 2, 2011, at http://www.water.ca.gov/pubs/ groundwater/bulletin 118/basindescriptions/1-52.pdf.

California Department of Water Resources, 2004w, California's groundwater-Individual basin descriptionsNorth Coast Hydrologic Region, Sanel Valley Groundwater Basin: California Department of Water Resources Bulletin 118, accessed August 2, 2011, at http://www.water.ca.gov/pubs/groundwater/bulletin_118/ basindescriptions/1-53.pdf.

California Department of Water Resources, 2004x, California's groundwater-Individual basin descriptionsNorth Coast Hydrologic Region, Smith River Plain Groundwater Basin: California Department of Water Resources Bulletin 118, accessed August 2, 2011, at http://www.water.ca.gov/pubs/groundwater/bulletin_118/ basindescriptions/1-1.pdf.

California Department of Water Resources, 2004y, California's groundwater-Individual basin descriptions - North Coast Hydrologic Region, Mad River Valley: California Department of Water Resources Bulletin 118, accessed August 2, 2011, at http://www.water.ca.gov/pubs/ groundwater/bulletin_118/basindescriptions/1-8.pdf.

California Department of Water Resources, 2004z, California's groundwater-Individual basin descriptions - North Coast Hydrologic Region, Mad River Groundwater Basin, Mad River Lowland Subbasin: California Department of Water Resources Bulletin 118, accessed August 2, 2011, at http://www.water.ca.gov/pubs/groundwater/bulletin_118/ basindescriptions/1-8.01.pdf.

California Department of Water Resources, 2004aa, California's groundwater-Individual basin descriptionsNorth Coast Hydrologic Region, Mad River Groundwater Basin, Dows Prairie Subbasin: California Department of Water Resources Bulletin 118, accessed August 2, 2011, at http://www.water.ca.gov/pubs/groundwater/bulletin_118/ basindescriptions/1-8.02.pdf.

California Department of Water Resources, 2004bb, California's groundwater-Individual basin descriptionsNorth Coast Hydrologic Region, Eureka Plain Groundwater Basin: California Department of Water Resources Bulletin 118, accessed August 2, 2011, at http://www.water.ca.gov/pubs/groundwater/bulletin_118/ basindescriptions/1-9.pdf. 
California Department of Water Resources, 2004cc, California's groundwater-Individual basin descriptionsNorth Coast Hydrologic Region, Eel River Valley Groundwater Basin: California Department of Water Resources Bulletin 118, accessed August 2, 2011, at http://www.water.ca.gov/pubs/groundwater/bulletin_118/ basindescriptions/1-10.pdf.

California Department of Water Resources, 2004dd, California's groundwater-Individual basin descriptionsNorth Coast Hydrologic Region, Lower Klamath River Valley Groundwater Basin: California Department of Water Resources Bulletin 118, accessed August 2, 2011, at http://www.water.ca.gov/pubs/groundwater/bulletin_118/ basindescriptions/1-14.pdf.

California Department of Water Resources, 2004ee, California's groundwater-Individual basin descriptionsNorth Coast Hydrologic Region, Big Lagoon Area Groundwater Basin: California Department of Water Resources Bulletin 118, accessed August 2, 2011, at http://www.water.ca.gov/pubs/groundwater/bulletin 118/ basindescriptions/1-27.pdf.

California Department of Water Resources, 2004ff, California's groundwater-Individual basin descriptionsNorth Coast Hydrologic Region, Fort Bragg Terrace Area Groundwater Basin: California Department of Water Resources Bulletin 118, accessed August 2, 2011, at http://www.water.ca.gov/pubs/groundwater/bulletin_118/ basindescriptions/1-21.pdf.

California Department of Water Resources, 2004gg, California's groundwater-Individual basin descriptionsNorth Coast Hydrologic Region, Ten Mile River Valley Groundwater Basin: California Department of Water Resources Bulletin 118, accessed August 2, 2011, at http://www.water.ca.gov/pubs/groundwater/bulletin_118/ basindescriptions/1-40.pdf.

California Department of Water Resources, 2004hh, California's groundwater-Individual basin descriptionsNorth Coast Hydrologic Region, Big River Valley Groundwater Basin: California Department of Water Resources Bulletin 118, accessed August 2, 2011, at http://www.water.ca.gov/pubs/groundwater/bulletin_118/ basindescriptions/1-45.pdf.

California Department of Water Resources, 2004ii, California's groundwater-Individual basin descriptionsNorth Coast Hydrologic Region, Knights Valley Groundwater Basin: California Department of Water Resources Bulletin 118, accessed August 2, 2011, at http://www.water.ca.gov/pubs/groundwater/bulletin 118/ basindescriptions/1-50.pdf.
California Department of Water Resources, Northern District, June 1982, Mendocino County coastal ground water study, 86 p., accessed September 25, 2014, at http://www. co.mendocino.ca.us/planning/pdf/Mendocino County Coastal_Ground_Water_Study.pdf.

California Irrigation Management Information System, 2005, CIMIS Reference Evapotranspiration Zones, accessed April 16, 2009, http://wwwcimis.water.ca.gov/cimis/pdf/ CimisRefEvapZones.pdf.

California State Water Resources Control Board, 2003, Report to the Governor and Legislature, A comprehensive groundwater quality monitoring program for California: Assembly Bill 599 March 2003, 121 p., accessed July 29, 2011, at http://www.waterboards.ca.gov/gama/docs/final ab 599 rpt to legis 7 31_03.pdf.

California State Water Resources Control Board, 2009, Geotracker GAMA: California State Water Resources Control Board database, accessed October 14, 2012, at https://geotracker.waterboards.ca.gov/gama/.

California State Water Resources Control Board, 2011, GAMA - Groundwater Ambient Monitoring and Assessment Program: State Water Resources Control Board website, accessed October 14, 2011, at http://www. waterboards.ca.gov/water issues/programs/gama/.

California State Water Resources Control Board, 2012, Geographic Environmental Information Management System GeoTracker (GEIMS) Leaking Underground Fuel/ Storage Tank (LUFT) database [digital data]: Sacramento, California, California Environmental Protection Agency, State Water Resources Control Board, Division of Water Quality, accessed November 28, 2012, at http://geotracker. waterboards.ca.gov/search.asp?CMD=search\&case number $=$ \&business name $=\&$ main street name $=\&$ city $=\& z i p=\&$ county $=\&$ SITE TYPE $=$ LUFT \&STA TUS $=\& B R A N C H=\& M A S T E R$ BASE $=\&$ Search $=$ Search.

Chapelle, F.H., 2001, Ground-water microbiology and geochemistry $(2 \mathrm{~d}$ ed.): New York, John Wiley and Sons, Inc., $477 \mathrm{p}$.

Chapelle, F.H., McMahon, P.B., Dubrovsky, N.M., Fuji, R.F., Oaksford, E.T., and Vroblesky, D.A., 1995, Deducing the distribution of terminal electron-accepting processes in hydrologically diverse groundwater systems: Water Resources Research, v. 31, no. 2, p. 359-371. (Also available at http://dx.doi.org/10.1029/94WR02525.)

Clark, I.D., and Fritz, Peter, 1997, Environmental isotopes in hydrogeology: New York, Lewis Publishers, 352 p. 
Cook, P.G., and Böhlke, J.K., 2000, Determining timescales for groundwater flow and solute transport, in Cook, P.G., and Herczeg, A.L., eds., Environmental tracers in subsurface hydrology: Boston, Kluwer Academic Publishers, p. 1-30. (Also available at http://dx.doi. org/10.1007/978-1-4615-4557-6 1.)

Craig, Harmon, and Lal, Devendra, 1961, The production rate of natural tritium: Tellus, v. 13, no. 1, p. 85-105. (Also available at http://dx.doi.org/10.1111/j.2153-3490.1961. tb00068.x.)

Dasgupta, P.K., Martinelango, P.K., Jackson, W.A., Anderson, T.A., Tian, Kang, Tock, R.W., and Rajagopalan, Srinath, 2005 , The origin of naturally occurring perchlorate-The role of atmospheric processes: Environmental Science \& Technology, v. 39, no. 6, p. 1569-1575. (Also available at http://dx.doi.org/10.1021/es048612x.)

Dodson, Allen, DePaolo, D.J., and Kennedy, B.M., 1998, Helium isotopes in lithospheric mantle: Evidence from Tertiary basalts of the western USA: Geochimica et Cosmochimica Acta, v. 62, no. 23-24, p. 3775-3787. (Also available at http://dx.doi.org/10.1016/S00167037(98)00267-1.)

Donnelly-Nolan, J.M., Burns, M.G., Goff, F.E., Peters, E.K., and Thompson, J.M., 1993, The Geysers-Clear Lake area, California-Thermal waters, mineralization, volcanism, and geothermal potential: Economic Geology, v. 88, no. 2, p. 301-316.

Earth Sciences Associates, January 1978, Upper Lake Ground Water Investigations for Lake County Flood Control and Water Conservation District, $25 \mathrm{p}$.

Erkan, Kamil, Blackwell, D.D., and Leidig, Mark, 2005, Crustal thermal regime at The Geysers/Clear Lake area, California: Proceedings of the World Geothermal Congress 2005, Antalya, Turkey, April 24-29, 2005, 9 p., accessed September 26, 2014, at http://www.geothermal-energy.org/ pdf/IGAstandard/WGC/2005/0767.pdf.

Farrar, C.D., 1986, Ground-water resources in Mendocino County, California: U.S. Geological Survey WaterResources Investigations Report 85-4258, 81 p. (Also available at http://pubs.er.usgs.gov/publication/wri854258.)

Flint, L.E., and Flint, A.L., 2007, Regional analysis of groundwater recharge: U.S. Geological Survey Professional Paper 1703-B, p. 29-60. (Also available at http://pubs.er.usgs.gov/ publication/pp1703B.)

Fontes, J.C., and Garnier, J.M., 1979, Determination of the initial ${ }^{14} \mathrm{C}$ activity of the total dissolved carbon-A review of the existing models and a new approach: Water Resources Research, v. 15, no. 2, p. 399-413. (Also available at http://dx.doi.org/10.1029/WR015i002p00399.)
Forrest, M.J., Kulongoski, J.T., Edwards, M.S., Farrar, C.D., Belitz, Kenneth, and Norris, R.D., 2013, Hydrothermal contamination of public supply wells in Napa and Sonoma Valleys, California: Applied Geochemistry, v. 33, p. 25-40. (Also available at http://dx.doi.org/10.1016/j. apgeochem.2013.01.012.)

Fram, M.S., and Belitz, Kenneth, 2011, Probability of detecting perchlorate under natural conditions in deep groundwater in California and the southwestern United States: Environmental Science \& Technology, v. 45, no. 4, p. 1271-1277. (Also available at http://dx.doi.org/10.1021/ es103103p.)

Fram, M.S., and Belitz, Kenneth, 2012, Status and understanding of groundwater quality in the TahoeMartis, Central Sierra, and Southern Sierra study units, 2006-2007-California GAMA Priority Basin Project: U.S. Geological Survey Scientific Investigations Report 2011-5216, 222 p. (Also available at http://pubs.usgs.gov/ sir/2011/5216/.)

Frankenberger, W.T., Jr., ed., 2002, Environmental chemistry of arsenic: New York, Marcel Dekker, 391 p.

Gilliom, R.J., Barbash, J.E., Crawford, C.G., Hamilton, P.A., Martin, J.D., Nakagaki, Naomi, Nowell, L.H., Scott, J.C., Stackelberg, P.E., Thelin, G.P., and Wolock, D.M., 2006, The quality of our nation's waters-Pesticides in the nation's streams and ground water, 1992-2001: U.S. Geological Survey Circular 1291, 172 p. (Also available at http://pubs.er.usgs.gov/publication/cir1291.)

Goff, F., Adams, A.I., Trujillo, P.E., Counce, D., and Mansfield, J., 1993, Geochemistry of thermal/mineral waters in the Clear Lake region, California, and implications of hot dry rock geothermal development: Los Alamos, New Mexico, U.S. Department of Energy, Los Alamos National Laboratory, Technical Report LA-12510HDR, 23 p., accessed September 26, 2014, at http://www. osti.gov/energycitations/servlets/purl/7090069-IdLmoI/ native/7090069.pdf.

Grove, A.T.,1999, World atlas of desertification (2d ed.), in Middleton, N.J., and Thomas, D.S.G., Earth surface processes and landforms: London, v. 24, no. 3. (Also available at http://onlinelibrary.wiley.com/doi/10.1002/ (SICI)1096-9837(199903)24:3\%3C280::AIDESP955\%3E3.0.CO;2-7/abstract.)

Helsel, D.R., and Hirsch, R.M., 2002, Statistical methods in water resources: U.S. Geological Survey Techniques of Water Resources Investigations, book 4, chap. A3, 523 p. (Also available at http://pubs.er.usgs.gov/publication/ twri04A3.) 
Hem, J.D., 1985, Study and interpretation of the chemical characteristics of natural water ( $3 \mathrm{~d}$ ed.): U.S. Geological Survey Water Supply Paper 2254, 264 p. (Also available at http://pubs.er.usgs.gov/publication/wsp2254.)

Hodgson, S.F., 2003, The geothermal map of California: Sacramento, California, California Department of Conservation, Division of Oil, Gas and Geothermal Resources, 3 p., accessed December 29, 2011, at http:// geoheat.oit.edu/bulletin/bull24-1/art1.pdf.

Isaaks, E.H., and Srivastava, R.M., 1989, Applied geostatistics: New York, Oxford University Press, 561 p.

Ivahnenko, Tammy, and Barbash, J.E., 2004, Chloroform in the hydrologic system-Sources, transport, fate, occurrence, and effects on human health and aquatic organisms: U.S. Geological Survey Scientific Investigations Report 2004-5137, 34 p. (Also available at http://pubs.er.usgs.gov/ publication/sir20045137.)

Johnson, M.J., 1978, Ground-water conditions in the Eureka area, Humboldt County, California, 1975: U.S. Geological Survey Water-Resources Investigations Report 78-127, $45 \mathrm{p}$. (Also available at http://pubs.er.usgs.gov/publication/ wri78127.)

Johnson, T.D., and Belitz, Kenneth, 2009, Assigning land use to supply wells for the statistical characterization of regional groundwater quality - Correlating urban land use and VOC occurrence: Journal of Hydrology, v. 370, no. 1-4, p. 100-108. (Also available at http://dx.doi.org/10.1016/j. jhydrol.2009.02.056.)

Jurgens, B.C., Burow, K.R., Dalgish, B.A., and Shelton, J.L., 2008, Hydrogeology, water chemistry, and factors affecting the transport of contaminants in the zone of contribution of a public-supply well in Modesto, eastern San Joaquin Valley, California: U.S. Geological Survey Scientific Investigations Report 2008-5156, 78 p. (Also available at http://pubs.er.usgs.gov/publication/sir20085156.)

Jurgens, B.C., McMahon, P.B., Chapelle, F.H., and Eberts, S.M., 2009, An Excel ${ }^{\circledR}$ workbook for identifying redox processes in ground water: U.S. Geological Survey OpenFile Report 2009-1004, 8 p. (Also available at http://pubs. er.usgs.gov/publication/ofr20091004.)

Kulongoski, J.T., Hilton, D.R., and Izbicki, J.A., 2003, Helium isotope studies in the Mojave Desert, CaliforniaImplications for groundwater chronology and regional seismicity: Chemical Geology, v. 202, no. 1-2, p. 95-113. (Also available at http://dx.doi.org/10.1016/j. chemgeo.2003.07.002.)

Kulongoski, J.T., and Belitz, Kenneth, 2004, Ground-Water Ambient Monitoring and Assessment Program: U.S. Geological Survey Fact Sheet 2004-3088, 2 p. (Also available at http://pubs.er.usgs.gov/publication/fs20043088.)
Kulongoski, J.T., Belitz, Kenneth, and Dawson, B.J., 2006, Ground-water quality data in the North San Francisco Bay hydrologic provinces, California, 2004-Results from the California Ground-Water Ambient Monitoring and Assessment (GAMA) Program: U.S. Geological Survey Data Series Report 167, 100 p. (Also available at http:// pubs.usgs.gov/ds/ds167.)

Kulongoski, J.T., Belitz, Kenneth, Landon, M.K., and Farrar, Christopher, 2010, Status and understanding of groundwater quality in the North San Francisco Bay groundwater basins, 2004 - California GAMA Priority Basin Project: U.S. Geological Survey Scientific Investigations Report 2010 5089, 65 p. (Also available at http://pubs.er.usgs.gov/ publication/sir20105089.)

Kulongoski, J.T., and Belitz, Kenneth, 2011, Status and understanding of groundwater quality in the Monterey Bay and Salinas Valley Basins, 2005-California GAMA Priority Basin Project: U.S. Geological Survey Scientific Investigations Report 2011-5058, 60 p. (Also available at http://pubs.er.usgs.gov/publication/sir20115058.)

Landon, M.K., Belitz, Kenneth, Jurgens, B.C., Kulongoski, J.T., and Johnson, T.D., 2010, Status and understanding of groundwater quality in the Central-Eastside San Joaquin Basin, 2006-California GAMA Priority Basin Project: U.S. Geological Survey Scientific Investigations Report 2009-5266, 97 p. (Also available at http://pubs.er.usgs.gov/ publication/sir20095266.)

Lapham, W.W., Hamilton, P.A., and Myers, D.N., 2005, National Water-Quality Assessment Program - Cycle IIRegional assessments of aquifers: U.S. Geological Survey Fact Sheet 2005-3013, 4 p., accessed January 5, 2012, at http://pubs.er.usgs.gov/publication/fs20053013.

Lindberg, R.D., and Runnells, D.D., 1984, Ground water redox reactions - An analysis of equilibrium state applied to Eh measurements and geochemical modeling: Science, v. 225 , no. 4665 , p. 925-927. (Also available at http:// dx.doi.org/10.1126/science.225.4665.925.)

Lucas, L.L., and Unterweger, M.P., 2000, Comprehensive review and critical evaluation of the half-life of tritium: Journal of Research of the National Institute of Standards and Technology, v. 105, no. 4, p. 541-549. (Also available at http://dx.doi.org/10.6028/jres.105.043.)

Manning, A.H., Solomon, D.K., and Thiros, S.A., 2005, ${ }^{3} \mathrm{H} /{ }^{\beta} \mathrm{He}$ age data in assessing the susceptibility of wells to contamination: Groundwater, v. 43, no. 3, p. 353-367. (Also available at http://dx.doi.org/10.1111/j.17456584.2005.0028.x.) 
Mathany, T.M., Dawson, B.J., Shelton, J.L., and Belitz, Kenneth, 2011, Groundwater-quality data in the Northern Coast Ranges study unit, 2009-Results from the California GAMA Program: U.S. Geological Survey Data Series 609, 92 p. (Also available at http://pubs.er.usgs.gov/publication/ ds609.)

McMahon, P.B., and Chapelle, F.H., 2008, Redox processes and water quality of selected principal aquifer systems: Ground Water, v. 46, no. 2, p. 259-271. (Also available at http://dx.doi.org/10.1111/j.1745-6584.2007.00385.x.)

Michel, R.L., 1989, Tritium deposition in the continental United States, 1953-1983: U.S. Geological Survey WaterResources Investigations Report 89-4072, 46 p. (Also available at http://pubs.er.usgs.gov/publication/wri894072.)

Michel, R.L., and Schroeder, R.A., 1994, Use of long-term tritium records from the Colorado River to determine timescales for hydrologic processes associated with irrigation in the Imperial Valley, California: Applied Geochemistry, v. 9, no. 4, p. 387-401. (Also available at http://dx.doi.org/10.1016/0883-2927(94)90061-2.)

Muir, K.S., and Webster, D.A., 1977, Geohydrology of part of the Round Valley Indian Reservation, Mendocino County, California: U.S. Geological Survey Water-Resources Investigations Report 77-22, 40 p. (Also available at http:// pubs.er.usgs.gov/publication/wri7722.)

Nakagaki, N., Price, C.V., Falcone, J.A., Hitt, K.J., and Ruddy, B.C., 2007, Enhanced National Land Cover Data 1992 (NLCDe 92): U.S. Geological Survey Raster digital data, accessed July 8, 2011, at http://water.usgs.gov/lookup/ getspatial?nlcde92.

Nakagaki, Naomi, and Wolock, D.M., 2005, Estimation of agricultural pesticide use in drainage basins using land cover maps and county pesticide data: U.S. Geological Survey Open-File Report 2005-1188, 56 p. (Also available at http://pubs.er.usgs.gov/publication/ofr20051188.)

National Oceanic and Atmospheric Administration, 2011, Climate of California, accessed July 26, 2011, at http:// www.wrcc.dri.edu/narratives/CALIFORNIA.htm.

Parker, D.R., Seyfferth, A.L., and Reese, B.K., 2008, Perchlorate in groundwater-A synoptic survey of "pristine" sites in the coterminous United States: Environmental Science \& Technology, v. 42, no. 5, p. 1465-1471. (Also available at http://dx.doi.org/10.1021/ es7021957.)

Peters, E.K., 1993, D- ${ }^{18}$ O enriched waters of the Coast Range Mountains, northern California-Connate and ore-forming fluids: Geochimica et Cosmochimica Acta, v. 57, no. 5, p. 1093-1104. (Also available at http://dx.doi. org/10.1016/0016-7037(93)90043-V.)
Petrisor, I.G., and Wells, J.T., 2008, Tracking chlorinated solvents in the environment: Environmental Forensics, no. 26, p. 130-152. (Also available at http://dx.doi. org/10.1039/9781847558343-00130.)

Piper, A.M., 1944, A graphic procedure in the geochemical interpretation of water analyses: American Geophysical Union Transactions, v. 25, no. 6, p. 914-928. (Also available at http://dx.doi.org/10.1029/TR025i006p00914.)

Plummer, L.N., Michel, R.L., Thurman, E.M., and Glynn, P.D., 1993, Environmental tracers for age dating young ground water, in Alley, W.M., ed., Regional ground-water quality: New York, Van Nostrand Reinhold, p. 255-294.

PRISM Group, Oregon State University, 2012, United States average annual precipitation, maximum and minimum temperature, 1971-2000, accessed August 9, 2012, at http:// prism.oregonstate.edu/.

Rajagopalan, Srinath, Anderson, Todd, Cox, Stephen, Harvey, Greg, Cheng, Qiugiong, and Jackson, W.A., 2009, Perchlorate in wet deposition across North America: U.S. Air Force Research Paper 34, accessed October 11, 2012, at http://digitalcommons.unl.edu/usafresearch/34.

Rao, Balaji, Anderson, T.A., Orris, G.J., Rainwater, K.A., Rajagopalan, Srinath, Sandvig, R.M., Scanlon, B.R., Stonestrom, D.A., Walvoord, M.A., and Jackson, W.A., 2007, Widespread natural perchlorate in unsaturated zones of the southwest United States: Environmental Science \& Technology, v. 41, no. 13, p. 4522-4528. (Also available at http://dx.doi.org/10.1021/es062853i.)

Ravenscroft, Peter, Brammer, Hugh, and Richards, Keith, 2009, Arsenic pollution-A global synthesis: West Sussex, United Kingdom, Wiley-Blackwell, 618 p.

Reimann, Clemens, and de Caritat, Patrice, 1998, Chemical elements in the environment - Factsheets for the geochemist and environmental scientist: Berlin, Springer-Verlag, 398 p.

Rowe, B.L., Toccalino, P.L., Moran, M.J., Zogorski, J.S., and Price, C.V., 2007, Occurrence and potential human-health relevance of volatile organic compounds in drinking water from domestic wells in the United States: Environmental Health Perspectives, v. 115, no. 11, p. 1539-1546. (Also

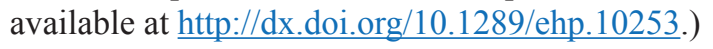

Ryan, J.G., and Langmuir, C.H., 1993, The systematics of boron abundances in young volcanic rocks: Geochemica et Cosmochimica Acta: v. 57, no. 1, p. 1489-1498. (Also available at $\mathrm{http}: / / \mathrm{dx}$.doi.org/10.1016/00167037(93)90008-K.)

Saucedo, G.J., Bedford, D.R., Raines, G.L., Miller, R.J., and Wentworth, C.M., 2000, GIS data for the geologic map of California: California Department of Conservation, Division of Mines and Geology, CD-ROM 2000-007. 
Scott, J.C., 1990, Computerized stratified random siteselection approaches for design of a ground-water-quality sampling network: U.S. Geological Survey Water-Resources Investigations Report 90-4101, 109 p. (Also available at http://pubs.er.usgs.gov/publication/wri904101.)

Smedley, P.L., and Kinniburgh, D.G., 2002, A review of the source, behaviour and distribution of arsenic in natural waters: Applied Geochemistry, v. 17, no. 5, p. 517-568. (Also available at http://dx.doi.org/10.1016/S08832927(02)00018-5.)

Smithsonian Institution National Museum of Natural History Global Volcanism Program, 2013, Clear Lake, accessed June 19, 2013, at http://www.volcano.si.edu/volcano. cfm?vn=323100.

Soil Mechanics and Foundation Engineers, Inc., March 1967, Big Valley ground-water recharge investigation for Lake County Flood Control and Water Conservation District, $62 \mathrm{p}$.

Sparks, D.L., 1995, Environmental soil chemistry: San Diego, Academic Press, 353 p.

State of California, 1999, Supplemental Report of the 1999 Budget Act 1999-00 Fiscal Year, Item 3940-001-0001, State Water Resources Control Board, accessed July 7 , 2011, at http://www.lao.ca.gov/1999/99-00 supp_rpt lang. html\#3940.

State of California, 2001a, Assembly Bill No. 599, Chapter 522, accessed July 7, 2011, at http://www.swrcb. ca.gov/gama/docs/ab_599_bill_20011005_chaptered.pdf.

State of California, 2001b, Groundwater Monitoring Act of 2001 - California Water Code, part 2.76, Sections 1078010782.3, accessed July 7, 2011, at http://www.leginfo. ca.gov/cgi-bin/displaycode?section=wat\&group $=10001$ $11000 \&$ file $=10780-10782.3$.

Stimac, James, Goff, Fraser, and Wohletz, Kenneth, 1997, Thermal modeling of the Clear Lake magmatic system, California-Implications for conventional and hot dry rock geothermal development: New Mexico, U.S. Department of Energy, Los Alamos National Laboratory, Technical Report LA-12778-MS, 38 p. (Also available at http://dx.doi. org/10.2172/505280.)

Sturchio, N.C., Böhlke, J.K., Beloso, A.D., Jr., Streger, S.H., Heraty, L.J., and Hatzinger, P.B., 2007, Oxygen and chlorine isotopic fractionation during perchlorate biodegradationLaboratory results and implications for forensics and natural attenuation studies: Environmental Science \& Technology, v. 41, no. 8, p. 2796-2802. (Also available at http://dx.doi. org/10.1021/es0621849.)
Summerhayes, C.P., Thorpe, S.A., and Ballard, R.D., 1996, Oceanography_An illustrated guide: United Kingdom, Manson Publishing, $352 \mathrm{p}$.

Thompson, J.M., Goff, F.E., and Donnelly, J.M., 1978, Chemical analyses of waters from springs and wells from the Clear Lake volcanic area, Northern California: U.S. Geological Survey Open-File Report 78-425, 12 p. (Also available at http://pubs.er.usgs.gov/publication/ofr78425.)

TIBCO Software Inc., 2008, TIBCO Spotfire S+ ${ }^{\circledR}$ 8.1, Guide to Statistics, v.1, accessed February 19, 2012, at http:// www-personal.umich.edu/ yryamada/statman1.pdf.

Toccalino, P.L., and Norman, J.E., 2006, Health-based screening levels to evaluate U.S. Geological Survey ground water quality data: Risk Analysis, v. 26, no. 5, p. 13391348. (Also available at http://dx.doi.org/10.1111/j.15396924.2006.00805.x.)

Toccalino, P.L., Norman, J.E., and Hitt, K.J., 2010, Quality of source water from public-supply wells in the United States, 1993-2007: U.S. Geological Survey Scientific Investigations Report 2010-5024, 126 p. (Also available at http://pubs.er.usgs.gov/publication/sir20105024.)

Toccalino, P.L., Norman, J.E., Phillips, R.H., Kauffman, L.J., Stackelberg, P.E., Nowell, L.H., Krietzman, S.J., and Post, G.B., 2004, Application of health-based screening levels to ground-water quality data in a state-scale pilot effort: U.S. Geological Survey Scientific Investigations Report 20045174, 64 p. (Also available at http://pubs.er.usgs.gov/ publication/sir20045174.)

Tolstikhin, I.N., and Kamenskiy, I.L., 1969, Determination of groundwater ages by the $\mathrm{T}-{ }^{3} \mathrm{He}$ method: Geochemistry International, v. 6, p. 810-811.

Torgersen, T., Jenkins, W.J., and Clarke, W.B., 1979, The tritium/helium-3 method in hydrology, in Isotope Hydrology 1978: Vienna, IAEA, IAEA-SM-228/2, p. 917-930.

Troiano, John, Weaver, Don, Marade, Joe, Spurlock, Frank, Pepple, Mark, Nordmark, Craig, and Bartkowiak, Donna, 2001, Summary of well water sampling in California to detect pesticide residues resulting from nonpoint source applications: Journal of Environmental Quality, v. 30, no. 2, p. 448-459. (Also available at http://dx.doi.org/10.2134/ jeq2001.302448x.)

United Nations Educational, Scientific, and Cultural Organization (UNESCO), 1979, Map of the world distribution of arid regions-Explanatory note: MAB Technical Notes, v. 7, 44 p.

U.S. Department of Commerce, 1990, 1990 Census of population and housing - Summary tape file 3A: U.S. Census Bureau, CD-ROM. 
U.S. Department of Commerce, 2011, NOAA, National Climatic Data Center, accessed July 26, 2011, at http:// www.ncdc.noaa.gov/oa/ncdc.html.

U.S. Department of Energy, 2006, The future of geothermal energy - Impact of Enhanced Geothermal Systems (EGS) on the United States in the $21^{\text {st }}$ century: An assessment by a Massachusetts Institute of Technology-led interdisciplinary panel, 372 p., accessed September 26, 2014, at http://www1. eere.energy.gov/geothermal/pdfs/future_geo energy.pdf.

U.S. Environmental Protection Agency, 1998, Code of Federal Regulations, title 40-Protection of environment, chapter 1-Environmental protection agency, subchapter EPesticide programs, part 159-Statements of policies and interpretations, subpart D-Reporting requirements for risk/ benefit information, 40 CFR 159.184: National Archives and Records Administration, September 19, 1997; amended June 19, 1998, accessed September 26, 2014, at http://www. ecfr.gov/cgi-bin/text-idx?SID=d6aaeaf5dcccd8642bddf15b51 6 edaf6\&node $=$ se $40.24 .159 \quad 1184 \&$ rgn $=$ div8.

U.S. Environmental Protection Agency, 2008, Drinking water health advisory for boron: U.S. Environmental Protection Agency 822-R-08-013, 53 p., accessed September 26, 2014, at http://www.epa.gov/safewater/ccl/pdfs/reg_determine2/ healthadvisory_ccl2-reg2_boron.pdf.

U.S. Environmental Protection Agency, 2009a, 2009 Edition of the drinking water standards and health advisories: Washington, D.C., U.S. Environmental Protection Agency, Office of Water, EPA 822-R-09-011, 12 p., accessed September 26, 2014, at http://water.epa.gov/action/ advisories/drinking/upload/dwstandards2009.pdf.

U.S. Environmental Protection Agency, 2009b, National primary drinking water regulations, accessed January 22 , 2013, at http://www.epa.gov/ogwdw/consumer/pdf/mcl.pdf.

U.S. Environmental Protection Agency, 2012, Arsenic in drinking water, accessed February 22, 2013, at http://water. epa.gov/lawsregs/rulesregs/sdwa/arsenic/index.cfm.

U.S. Environmental Protection Agency, 2013, Technology Transfer Network-Air Toxics Web site, Vinyl chloride, accessed July 18, 2014, at http://www.epa.gov/ttn/atw/ hlthef/vinylchl.html.

U.S. Geological Survey, 2003, Principal aquifers of the 48 conterminous United States, Hawaii, Puerto Rico, and the U.S. Virgin Islands, accessed September 26, 2014, at http:// www.nationalatlas.gov/mld/aquifrp.html.

U.S. Geological Survey, 2004, Clear Lake Volcanic Field, California, U.S. Geological Survey: Volcano Hazards Program, accessed February 20, 2013, at http://volcanoes. usgs.gov/volcanoes/clear lake/.
U.S. Geological Survey, 2005, Mineral resources on-line spatial data-Mineral Resources Data System (MRDS), accessed January 10, 2012, at http://tin.er.usgs.gov/mrds/.

U.S. Geological Survey, 2011, What is the Priority Basin Project?: U.S. Geological Survey California Water Science Center website, accessed November 23, 2011, at http:// ca.water.usgs.gov/gama/.

Vogel, J.C., and Ehhalt, D., 1963, The use of the carbon isotopes in groundwater studies, in Radioisotopes in Hydrology: Vienna, International Atomic Energy Agency, p. 383-395.

Webster, J.G., and Nordstrom, D.K., 2003, Geothermal arsenic - The source, transport and fate of arsenic in geothermal systems, in Welch, A.H., and Stollenwerk, K.G., eds., Arsenic in ground water-Geochemistry and occurrence: Boston, Massachusetts, Kluwer Academic Publishers, p. 101-125.

Welch, A.H., Lico, M.S., and Hughes, J.L., 1988, Arsenic in ground water of the western United States: Ground Water, v. 26, no. 3, p. 333-347. (Also available at http://dx.doi. org/10.1111/j.1745-6584.1988.tb00397.x.)

Welch, A.H., Oremland, R.S., Davis, J.A., and Watkins, S.A., 2006, Arsenic in ground water-A review of current knowledge and relation to the CALFED solution area with recommendations for needed research: San Francisco Estuary \& Watershed Science, v. 4, no. 2, 32 p., accessed July 19, 2011, at http://repositories.cdlib.org/jmie/sfews/ vol4/iss2/art4/.

Welch, A.H., Westjohn, D.B., Helsel, D.R., and Wanty, R.B., 2000, Arsenic in ground water of the United States-Occurrence and geochemistry: Groundwater, v. 38, no. 4, p. 589-604. (Also available at http://dx.doi. org/10.1111/j.1745-6584.2000.tb00251.x.)

Wood, C.A., and Kienle, Jürgen, 1992, Volcanoes of North America-United States and Canada: Cambridge University Press, $354 \mathrm{p}$.

Zogorski, J.S., Carter, J.M., Ivahnenko, Tamara, Lapham, W.W., Moran, M.J., Rowe, B.L., Squillace, P.J., and Toccalino, P.L., 2006, The quality of our Nation's watersVolatile organic compounds in the Nation's ground water and drinking-water supply wells: U.S. Geological Survey Circular 1292, 101 p. (Also available at http://pubs.er.usgs. gov/publication/cir1292.) 


\section{Appendix A. Map of the Northern Coast Ranges (NOCO) Study Unit}

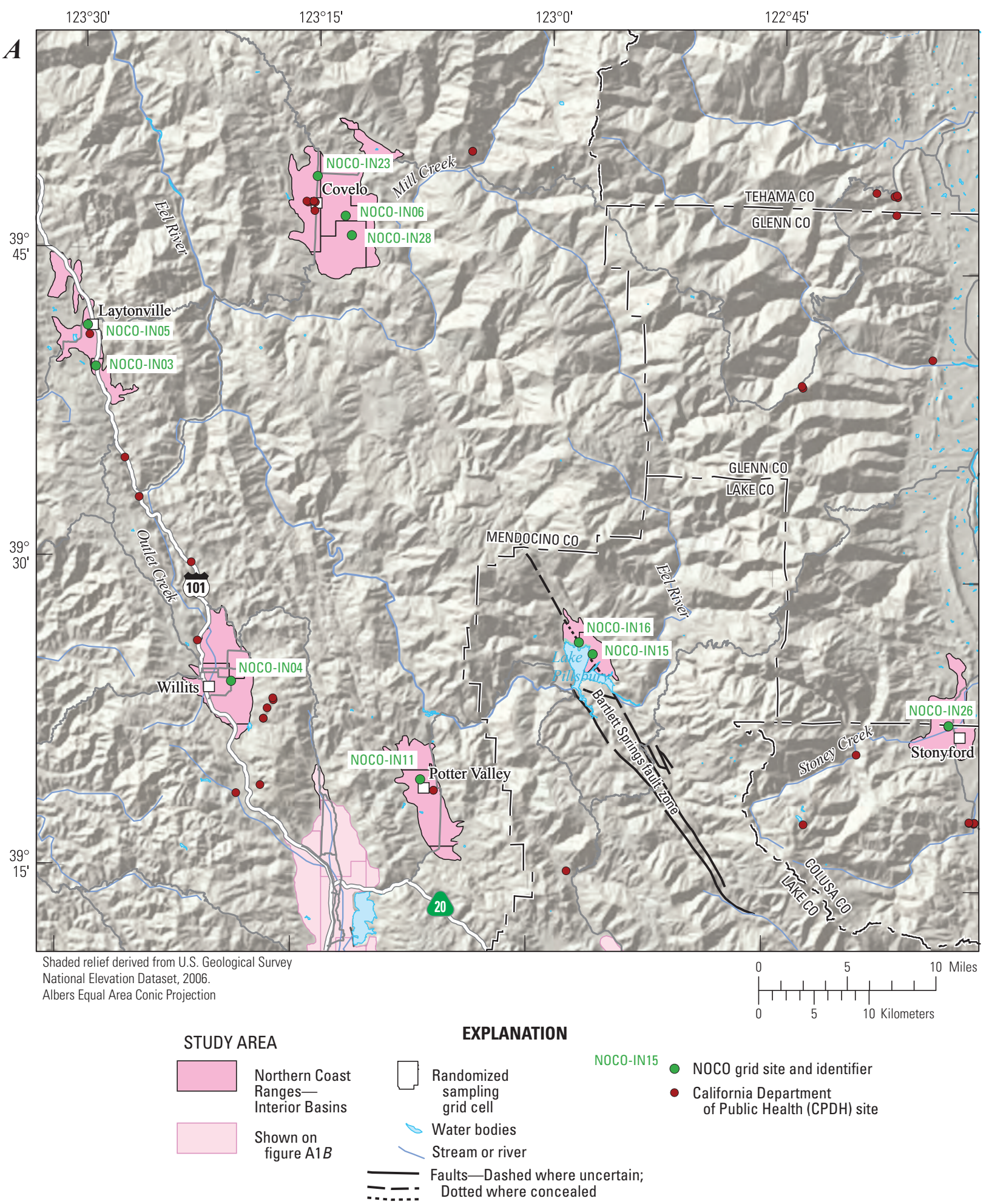

Figure A1. Northern Coast Ranges (NOCO) Groundwater Ambient Monitoring and Assessment (GAMA) study unit showing the location of $(A)$ the northern part, $(B)$ the central part, and $(C)$ the southern part of the Interior Basins (NOCO-IN) study area and $(D)$ the northern part, $(E)$ the central part, $(F)$ the southern part of the Coastal Basins (NOCO-CO) study area, the boundaries of the California Department of Water Resources (CDWR) defined groundwater basins, the distribution of the study area grid cells, the location of California Department of Public Health (CDPH) sites, and the location of sampled U.S. Geological Survey (USGS) grid sites, major cities, major roads, topographic features, and hydrologic features. 
$123^{\circ} 30$ $123^{\circ} 15^{\prime}$ $123^{\circ} 0^{\prime}$ $122^{\circ} 45$

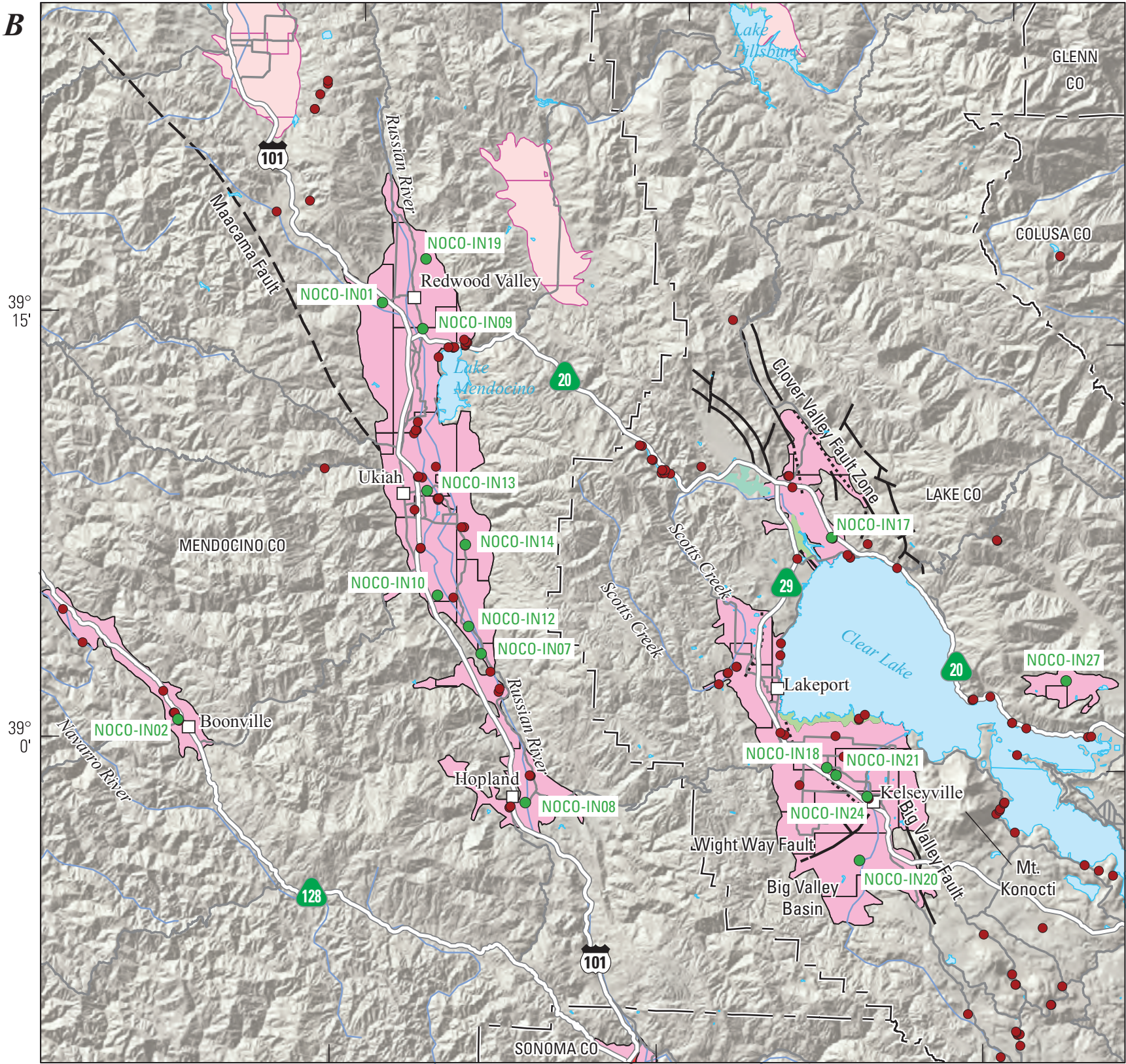

Shaded relief derived from U.S. Geological Survey

National Elevation Dataset, 2006.

Albers Equal Area Conic Projection

STUDY AREA

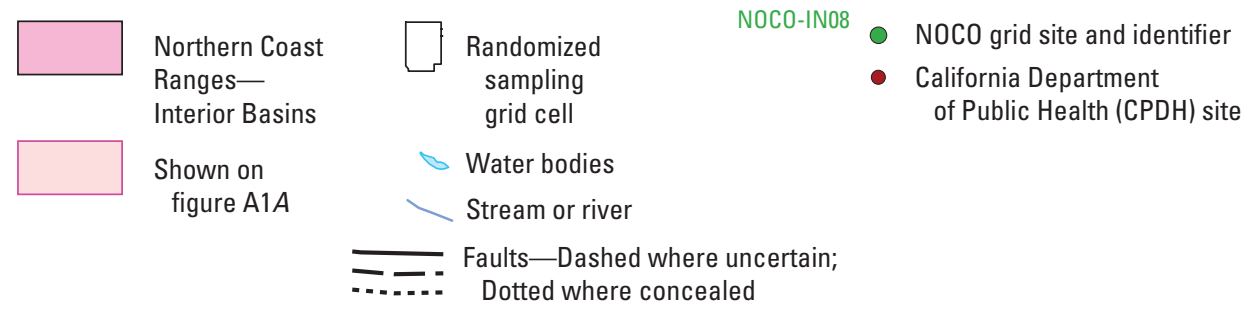

Figure A1. - Continued 


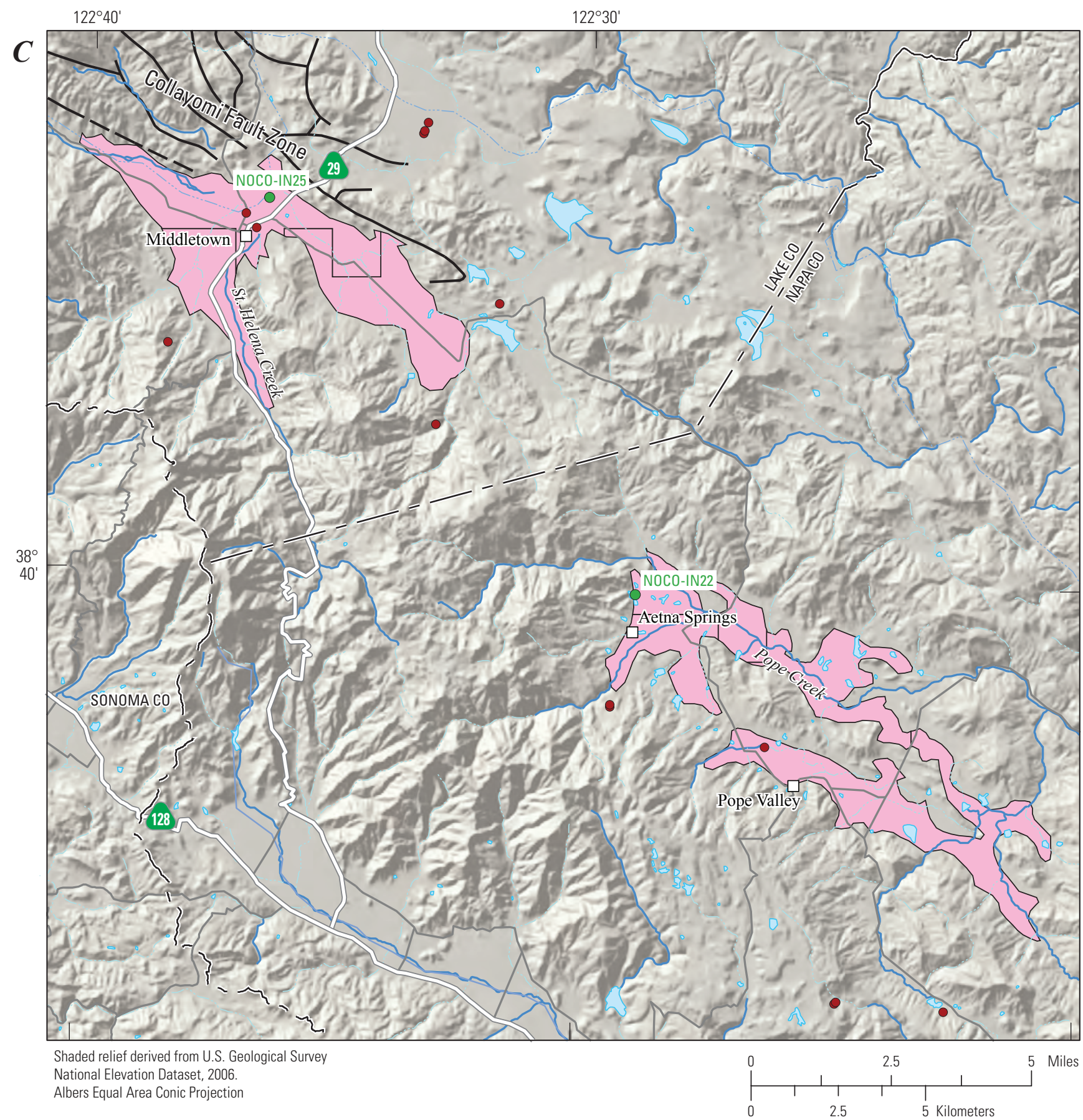

EXPLANATION

\section{STUDY AREA}

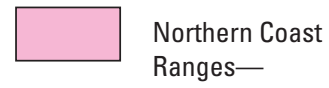

Interior Basins

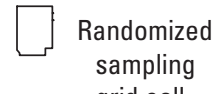

grid cell

\& Water bodies

Stream or river

- Faults-Dashed where uncertain
NOCO-IN22

- NOCO grid site and identifier

- California Department of Public Health (CPDH) site

Figure A1. - Continued 


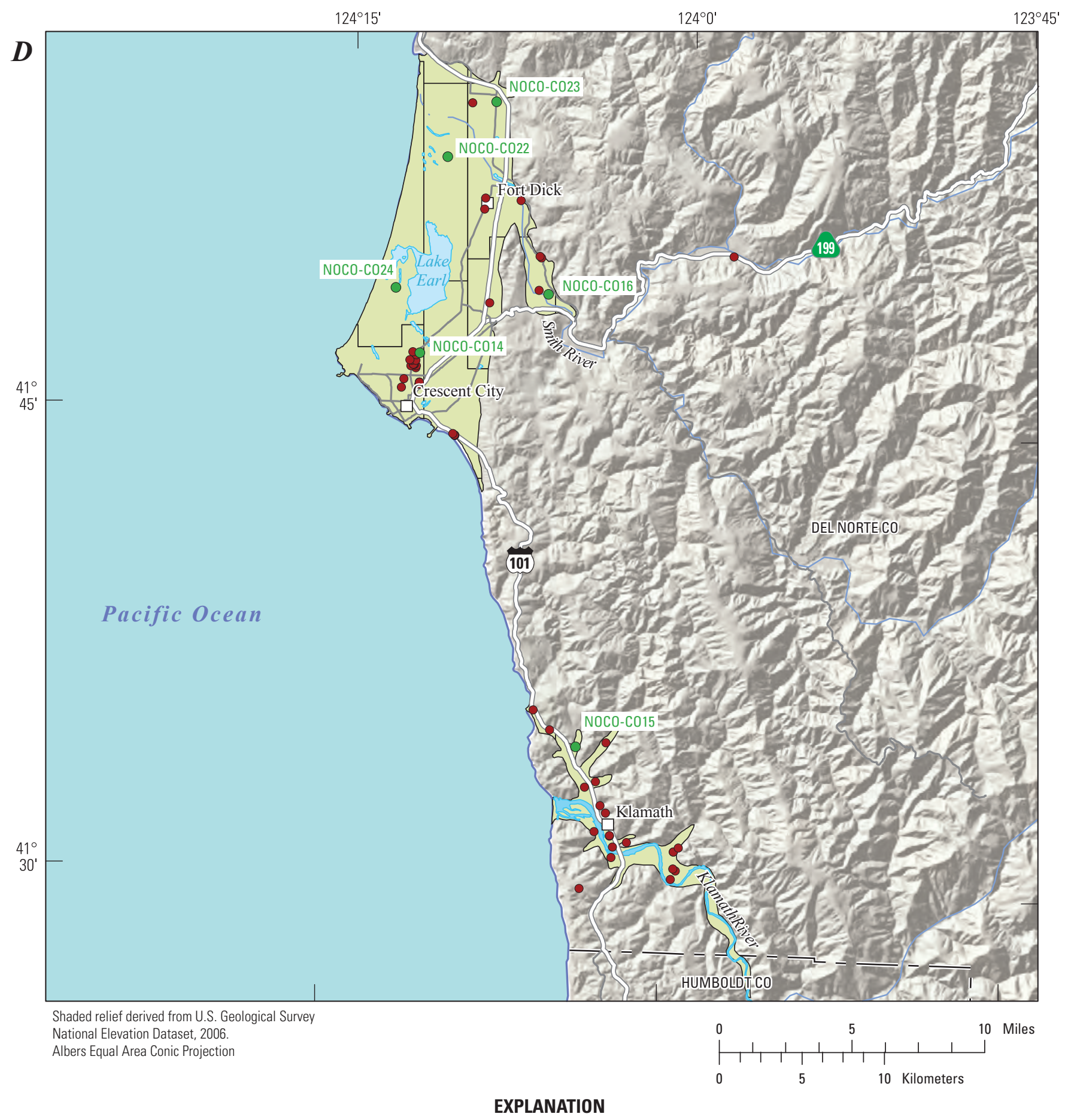

STUDY AREA

Figure A1. - - Continued 


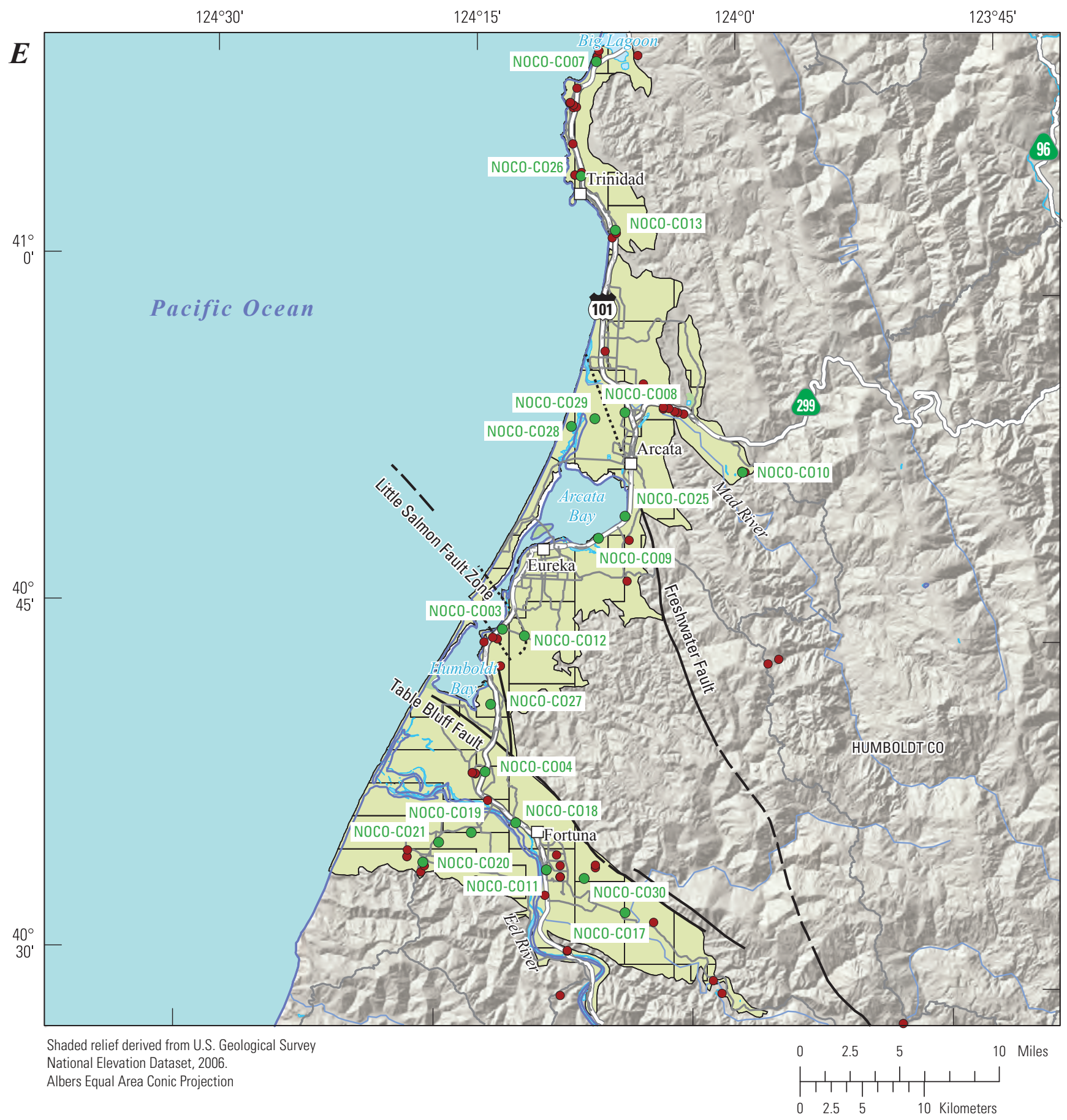

STUDY AREA

EXPLANATION

\begin{tabular}{|c|c|}
\hline $\begin{array}{l}\text { Northern Coast } \\
\text { Ranges- } \\
\text { Coastal Basins }\end{array}$ & $\begin{array}{l}\text { NOCO grid site and identifier } \\
\text { California Department } \\
\text { of Public Health (CPDH) site }\end{array}$ \\
\hline & \\
\hline & \\
\hline & \\
\hline
\end{tabular}

Figure A1. - Continued 


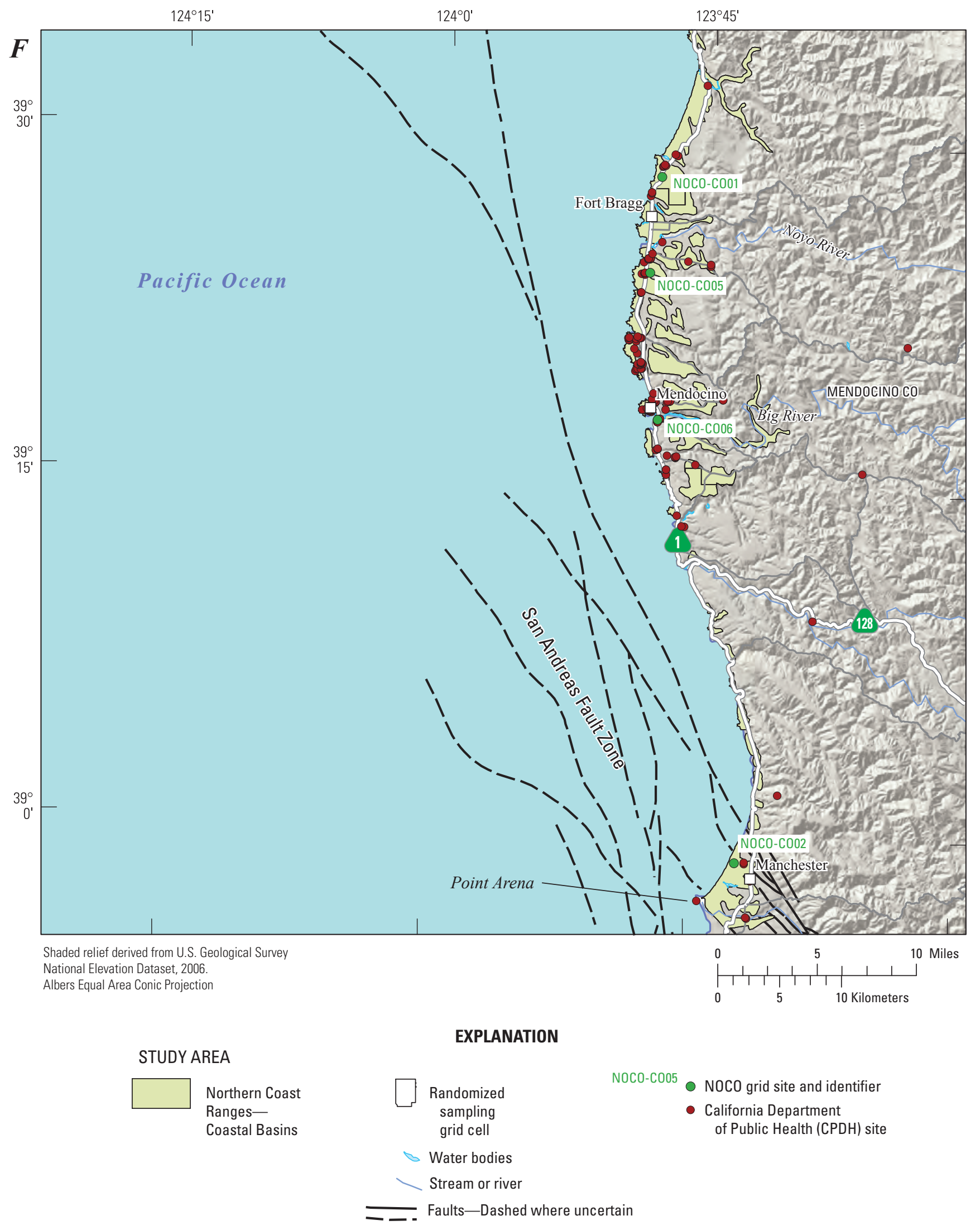

Figure A1. - Continued 


\section{Appendix B. Ancillary Datasets}

\section{Land-Use Classification}

Land use was classified by using an enhanced version of the satellite-derived (30-m pixel resolution) nationwide USGS National Land Cover Dataset (NLCD) (Nakagaki and others, 2007). This dataset has been used in previous national and regional studies relating land use to water quality (Gilliom and others, 2006; Zogorski and others, 2006). The dataset characterizes land use during the early 1990s. One pixel in the dataset imagery represents a land area of 9,688 square feet $\left(\mathrm{ft}^{2}\right)\left(900\right.$ square meters $\left.\left[\mathrm{m}^{2}\right]\right)$, calculated from the pixel of $98 \mathrm{ft}(30 \mathrm{~m})$. The imagery was classified into 25 land-cover classifications (Nakagaki and Wolock, 2005). These 25 landcover classifications were aggregated into three principal landuse classes - urban, agricultural, and natural.

Percentages of the three land-use classes in the study unit and study areas, in areas within a radius of $500 \mathrm{~m}(500-\mathrm{m}$ buffers) of each USGS-GAMA Program grid site, and in areas within 500-m buffers of each CDPH site were calculated by using Esri ArcGIS ${ }^{\circledR}$ (Johnson and Belitz, 2009; tables B1, B2). A 500-m buffer surrounding a site has been shown to be effective at correlating urban land use with VOC occurrence for the purposes of statistical characterization (Johnson and Belitz, 2009).

\section{Septic Tank and Leaking or Formerly Leaking Underground Fuel Tank Density}

Septic tanks generally are associated with dispersed residences and may occur in areas classified as natural or agricultural in addition to areas classified as urban. Septic tank density was determined from the 1990 Census of Population and Housing: Summary Tape File 3A dataset (U.S. Department of Commerce, 1990). The density of septic tanks in each housing census block was calculated from the number of tanks and block area. The density of septic tanks around each USGS-GAMA grid site was then calculated from the area-weighted mean of the block densities within a 500-m buffer around the site (Tyler Johnson, U.S. Geological Survey, California Water Science Center, written commun., 2013; table B2).

LUFTs generally are associated with urban land use, although they may occur in areas classified as natural or agricultural. LUFT density was determined from the locations of tanks in the SWRCB's GeoTracker database of environmental cleanup sites (California State Water Resources Control Board, 2012). The density of LUFTs was calculated by using Theissen polygons (Tyler Johnson, U.S. Geological Survey, California Water Science Center, written commun., 2007). The boundaries of the Theissen polygon around a particular LUFT were created by bisecting the linear distances between the LUFT and all the surrounding LUFTs. The density of LUFTs in the polygon is the number of tanks in the polygon (generally one) divided by the area of the polygon in square kilometers. Each USGS-GAMA grid site was assigned the LUFT density of the Theissen polygon in which it is located (table B2).

\section{Well Construction Information}

Most well-construction data were from drillers' logs filed with the CDWR. For some wells, well construction data were obtained from ancillary records of site owners or the USGS National Water Information System (NWIS) database. Well depths and depths to the top and bottom of perforations for USGS-GAMA grid sites are listed in table B3. The spring was assigned a value of "at LSD" (at land-surface datum) for the well depth and depths to the top and bottom of the perforations, equivalent to $0 \mathrm{ft}$ bls. USGS-GAMA grid site verification procedures are described by Mathany and others (2011). Land-surface altitudes were obtained from USGS digital elevation GIS coverages and are reported in feet relative to the North American Vertical Datum of 1988 (NAVD 88) (table B3).

\section{Aridity Index}

The climate at each USGS-GAMA grid site was represented by an aridity index (United Nations Educational, Scientific, and Cultural Organization, 1979; Grove, 1999; table B3):

$$
\text { aridity index }=\frac{\text { average annual precipitation }}{\text { average annual evapotranspiration }} .
$$

Higher values of the index correspond to wetter conditions. Average annual precipitation for each site was extracted from the PRISM average annual precipitation for 1971-2000 GIS coverage (PRISM Group, Oregon State University, 2012). Average annual evapotranspiration for each site was extracted from an Esri ArcGIS ${ }^{\circledR}$ coverage modified from Flint and Flint (2007). The modification consisted of calibrating the evapotranspiration values to the measured California Irrigation Management Information System reference evapotranspiration values (California Irrigation Management Information System, 2005; Alan Flint, U.S. Geological Survey, California Water Science Center, oral commun., 2009).

\section{Distance to Nearest Hot Spring and Geothermal Well}

Distances to nearest hot spring and geothermal well were used as potential direct indicators of groundwater interaction with the localized geothermal systems located within the Geysers-Clear Lake area. Hot spring locations were obtained from the USGS MRDS, which is a collection of reports describing metallic and nonmetallic mineral resources throughout the world. Included in the MRDS are deposit name, location, commodity, deposit description, geologic characteristics, production, reserves, resources, and references (U.S. Geological Survey, 2005). Geothermal well locations were obtained from the California Department of Conservation DOGGR database. DOGGR oversees the drilling, operation, maintenance, and plugging and abandonment of oil, natural gas, and geothermal wells. Each USGS-GAMA grid site was assigned the Euclidean distance, in kilometers, to the nearest hot spring and geothermal well using the "Near" tool in the Esri ArcGIS ${ }^{\circledR}$ software package (table B3). 


\section{Groundwater Age Classification}

Groundwater dating techniques indicate the time since the groundwater was recharged into the primary aquifer system. The techniques used in this report to estimate groundwater residence times or 'age' were those based on tritium (for example: Tolstikhin and Kamenskiy, 1969; Torgersen and others, 1979) and carbon-14 activities (for example: Vogel and Ehhalt, 1963; Plummer and others, 1993).

Tritium is a short-lived radioactive isotope of hydrogen with a half-life of 12.32 years (Lucas and Unterweger, 2000). Tritium is produced naturally in the atmosphere from the interaction of cosmogenic radiation with nitrogen (Craig and Lal, 1961), by aboveground nuclear explosions, and by the operation of nuclear reactors. Tritium enters the hydrologic cycle following oxidation to tritiated water. Aboveground nuclear explosions resulted in a large increase in tritium values in precipitation, beginning in about 1952 and peaking in 1963 at values over 1,000 TU in the northern hemisphere (Michel, 1989). Radioactive decay over a period of 50 years would decrease tritium values of 10 TU to 0.6 TU. Tritium values in precipitation under natural conditions in the NOCO study unit in 2009 would be about 2 to 5 TU (Robert Michel, U.S. Geological Survey, California Water Science Center, Menlo Park Stable Isotope and Tritium Laboratories, written commun., 2013).

Previous investigations have used a range of tritium values from 0.3 to $1.0 \mathrm{TU}$ as thresholds for indicating presence of water that has exchanged with the atmosphere since 1952 (Michel, 1989; Plummer and others, 1993; Michel and Schroeder, 1994; Clark and Fritz, 1997; Manning and others, 2005). For groundwater samples collected for the NOCO study unit in 2009 (Mathany and others, 2011), tritium values greater than a threshold of $0.5 \mathrm{TU}$ were defined as indicating presence of groundwater recharged since 1952.

Carbon-14 $\left({ }^{14} \mathrm{C}\right)$ is a widely used chronometer based on the radiocarbon content of organic and inorganic carbon. Dissolved inorganic carbon species, carbonic acid, bicarbonate, and carbonate typically are used for ${ }^{14} \mathrm{C}$ dating of groundwater. ${ }^{14} \mathrm{C}$ is formed in the atmosphere by the interaction of cosmic-ray neutrons with nitrogen and, to a lesser degree, with oxygen and carbon. ${ }^{14} \mathrm{C}$ is incorporated into carbon dioxide and mixed throughout the atmosphere. The carbon dioxide enters the hydrologic cycle because it dissolves in precipitation and surface water in contact with the atmosphere. ${ }^{14} \mathrm{C}$ activity in groundwater, expressed as percent modern carbon (pmc), reflects the time since groundwater was last exposed to the atmospheric ${ }^{14} \mathrm{C}$ source. ${ }^{14} \mathrm{C}$ has a half-life of 5,730 years and can be used to estimate groundwater ages ranging from 1,000 to approximately 30,000 years before present.

The ${ }^{14} \mathrm{C}$ age (residence time, presented in years) is calculated on the basis of the decrease in ${ }^{14} \mathrm{C}$ activity as a result of radioactive decay since groundwater recharge, relative to an assumed initial ${ }^{14} \mathrm{C}$ concentration (Clark and Fritz, 1997). An average initial ${ }^{14} \mathrm{C}$ activity of $100 \mathrm{pmc}$ is assumed for this study, with estimated errors on calculated groundwater ages up to \pm 20 percent. Calculated ${ }^{14} \mathrm{C}$ ages in this study are referred to as "uncorrected" because they have not been adjusted to consider exchanges with sedimentary sources of carbon (Fontes and Garnier, 1979). Groundwater with a ${ }^{14} \mathrm{C}$ activity of $>88 \mathrm{pmc}$ is reported as having an age of $<1,000$ years; no attempt has been made to refine ${ }^{14} \mathrm{C}$ ages $<1,000$ years. Measured values of pmc can be $>100 \mathrm{pmc}$ because the definition of the ${ }^{14} \mathrm{C}$ activity in "modern" carbon does not include the excess ${ }^{14} \mathrm{C}$ produced in the atmosphere by aboveground nuclear weapons testing. For the NOCO study unit, ${ }^{14} \mathrm{C}$ activity $<88$ pmc was defined as indicative of the presence of groundwater recharged before 1952.

In this study, the age distributions of samples are classified as pre-modern, modern, or mixed ages (table B4). Groundwater with tritium activity $<0.5 \mathrm{TU}$ and ${ }^{14} \mathrm{C}<88 \mathrm{pmc}$ is designated as pre-modern, defined as having been recharged before 1952. Groundwater with tritium activities $>0.5 \mathrm{TU}$ and ${ }^{14} \mathrm{C}>88 \mathrm{pmc}$ is designated as modern, defined as having been recharged after 1952. Samples with pre-modern and modern components are designated as mixed-age groundwater, which includes substantial fractions of old and young waters. In reality, pre-modern groundwater could contain very small fractions of modern groundwater, and modern groundwater could contain small fractions of pre-modern groundwater. Although more sophisticated lumped parameter models that incorporate mixing are available for analyzing age distributions (for example, Cook and Böhlke, 2000), use of these alternative models to characterize age mixtures was beyond the scope of this report. Rather, classification into modern (recharged after 1952), mixed-age, and pre-modern (recharged before 1952) categories was sufficient to provide an appropriate and useful characterization for the purposes of examining groundwater quality.

\section{Classification of Geochemical Condition}

Geochemical conditions investigated as potential explanatory variables in this report include oxidationreduction (redox) characteristics, $\mathrm{pH}$, and DO (table B5). Redox conditions influence the mobility of many organic and inorganic constituents (McMahon and Chapelle, 2008). Along groundwater flow paths, redox conditions commonly proceed along a well-documented sequence of Terminal Electron Acceptor Processes (TEAPs); one TEAP typically dominates at a particular time and aquifer location (Chapelle and others, 1995; Chapelle, 2001). The predominant TEAPs (in order of least to most reducing) are oxygen-reducing, nitrate-reducing, manganese-reducing, iron-reducing, sulfate-reducing, and methanogenesis. The presence of redox-sensitive chemical species suggesting more than one TEAP may indicate mixed waters from different redox zones upgradient of the site, a well screened across more than one redox zone, or spatial heterogeneity in microbial activity in the aquifer. Different redox elements (for example, iron, manganese, and sulfur) tend not to reach overall equilibrium in most natural water systems (Lindberg and Runnels, 1984); therefore, a single redox measurement usually cannot represent the system, further complicating the assessment of redox conditions. $\mathrm{pH}$ is the measure of hydrogen-ion activity in a water sample and is sensitive to a number of geochemical reactions in addition to redox conditions. DO is a measure of how much oxygen is dissolved in a water sample. 
Table B1. Land-use classification for the Northern Coast Ranges study unit, 2009, California GAMA Priority Basin Project.

[GAMA, Groundwater Ambient Monitoring and Assessment Program]

\begin{tabular}{|c|c|c|c|c|}
\hline & \multicolumn{3}{|c|}{ Land-use category } & \multirow[b]{2}{*}{ Classification } \\
\hline & $\begin{array}{l}\text { Agricultural } \\
\text { (percent) }\end{array}$ & $\begin{array}{c}\text { Natural } \\
\text { (percent) }\end{array}$ & $\begin{array}{c}\text { Urban } \\
\text { (percent) }\end{array}$ & \\
\hline \multicolumn{5}{|l|}{ Northern Coast Ranges (NOCO) study unit } \\
\hline Study unit as a whole & 29 & 60 & 11 & Natural \\
\hline Study unit based on buffer areas surrounding grid sites & 37 & 46 & 17 & Mixed \\
\hline $\begin{array}{l}\text { Study unit based on buffer areas surrounding California Department of } \\
\text { Public Health (CDPH) sites }\end{array}$ & 19 & 56 & 25 & Natural \\
\hline \multicolumn{5}{|l|}{ Interior Basins (NOCO-IN) study area } \\
\hline Study area as a whole & 33 & 60 & 7 & Natural \\
\hline Study area based on buffer areas surrounding grid sites & 43 & 47 & 10 & Mixed \\
\hline Study area based on buffer areas surrounding CDPH sites & 36 & 45 & 19 & Mixed \\
\hline \multicolumn{5}{|l|}{ Coastal Basins (NOCO-CO) study area } \\
\hline Study area as a whole & 25 & 60 & 14 & Natural \\
\hline Study area based on buffer areas surrounding grid sites & 31 & 46 & 23 & Mixed \\
\hline Study area based on buffer areas surrounding CDPH sites & 11 & 61 & 28 & Natural \\
\hline
\end{tabular}

Table B2. Land-use percentages, septic tank density, and leaking (or formerly leaking) underground fuel tank (LUFT) density for areas within a 500-meter radius of the U.S. Geological Survey (USGS) GAMA grid sites in the Northern Coast Ranges study unit, 2009, California GAMA Priority Basin Project.

[USGS-GAMA site identification numbers: NOCO-IN, Northern Coast Ranges study unit, Interior Basins study area; NOCO-CO, Northern Coast Ranges study unit, Coastal Basins study area. Abbreviation: tanks $/ \mathrm{km}^{2}$, tanks per square kilometer]

\begin{tabular}{|c|c|c|c|c|c|}
\hline \multirow{2}{*}{$\begin{array}{l}\text { USGS-GAMA site } \\
\text { identification number }\end{array}$} & \multicolumn{3}{|c|}{ Land-use percentages ${ }^{1}$} & \multirow{2}{*}{$\begin{array}{l}\text { Septic tank density } \\
\left(\tan \mathbf{k s} / \mathbf{k m}^{2}\right)\end{array}$} & \multirow{2}{*}{$\begin{array}{r}\text { LUFT density } \\
\text { (tanks/km²) }\end{array}$} \\
\hline & Agricultural & Natural & Urban & & \\
\hline \multicolumn{6}{|c|}{ Interior Basins study area } \\
\hline NOCO-IN-02 & 42 & 6 & 52 & 8.0 & 1.71 \\
\hline NOCO-IN-03 & 6 & 93 & 1 & 12.5 & 0.01 \\
\hline NOCO-IN-04 & 49 & 14 & 37 & 10.7 & 0.01 \\
\hline NOCO-IN-06 & 0 & 100 & 0 & 4.1 & 0.02 \\
\hline NOCO-IN-07 & 22 & 78 & 0 & 3.5 & 0.01 \\
\hline NOCO-IN-08 & 80 & 20 & 0 & 2.3 & 0.79 \\
\hline NOCO-IN-09 & 56 & 44 & 0 & 24.9 & 0.22 \\
\hline NOCO-IN-10 & 82 & 18 & 0 & 4.3 & 0.02 \\
\hline NOCO-IN-14 & 70 & 25 & 5 & 4.7 & 0.02 \\
\hline NOCO-IN-15 & 0 & 99 & 1 & 0.1 & 0 \\
\hline NOCO-IN-16 & 1 & 99 & 0 & 0.1 & 0 \\
\hline NOCO-IN-17 & 88 & 10 & 2 & 4.9 & 0.08 \\
\hline NOCO-IN-18 & 93 & 4 & 3 & 12.1 & 0.01 \\
\hline NOCO-IN-19 & 78 & 22 & 0 & 5.4 & 0.05 \\
\hline NOCO-IN-20 & 0 & 100 & 0 & 3.3 & 0.02 \\
\hline
\end{tabular}


Table B2. Land-use percentages, septic tank density, and leaking (or formerly leaking) underground fuel tank (LUFT) density for areas within a 500-meter radius of the U.S. Geological Survey (USGS) GAMA grid sites in the Northern Coast Ranges study unit, 2009, California GAMA Priority Basin Project.-Continued

[USGS-GAMA site identification numbers: NOCO-IN, Northern Coast Ranges study unit, Interior Basins study area; NOCO-CO, Northern Coast Ranges study unit, Coastal Basins study area. Abbreviation: tanks $/ \mathrm{km}^{2}$, tanks per square kilometer]

\begin{tabular}{|c|c|c|c|c|c|}
\hline \multirow{2}{*}{$\begin{array}{l}\text { USGS-GAMA site } \\
\text { identification number }\end{array}$} & \multicolumn{3}{|c|}{ Land-use percentages ${ }^{1}$} & \multirow{2}{*}{$\begin{array}{l}\text { Septic tank density } \\
\quad\left(\operatorname{tanks} / \mathbf{k m}^{2}\right)\end{array}$} & \multirow{2}{*}{$\begin{array}{c}\text { LUFT density } \\
\text { (tanks/km²) }\end{array}$} \\
\hline & Agricultural & Natural & Urban & & \\
\hline \multicolumn{6}{|c|}{ Interior Basins study area-Continued } \\
\hline NOCO-IN-21 & 84 & 2 & 14 & 11.4 & 0.01 \\
\hline NOCO-IN-22 & 23 & 77 & 0 & 1.7 & 0.01 \\
\hline NOCO-IN-23 & 0 & 100 & 0 & 12.4 & 0 \\
\hline NOCO-IN-24 & 48 & 29 & 23 & 7.2 & 0.06 \\
\hline NOCO-IN-25 & 56 & 44 & 0 & 4.8 & 0.08 \\
\hline NOCO-IN-26 & 0 & 100 & 0 & 0.3 & 0 \\
\hline NOCO-IN-27 & 46 & 54 & 0 & 1.3 & 0.07 \\
\hline NOCO-IN-28 & 0 & 100 & 0 & 4.1 & 0.02 \\
\hline \multicolumn{6}{|c|}{ Coastal Basins study area } \\
\hline NOCO-CO-01 & 0 & 23 & 77 & 21.4 & 0.40 \\
\hline NOCO-CO-02 & 78 & 22 & 0 & 0.4 & 0.02 \\
\hline NOCO-CO-03 & 34 & 19 & 47 & 7.6 & 0.57 \\
\hline NOCO-CO-04 & 0 & 89 & 11 & 3.2 & 0.14 \\
\hline NOCO-CO-05 & 0 & 40 & 60 & 39.3 & 0.50 \\
\hline NOCO-CO-06 & 0 & 97 & 3 & 7.7 & 0.43 \\
\hline NOCO-CO-07 & 0 & 78 & 22 & 1.2 & 0.02 \\
\hline NOCO-CO-08 & 58 & 1 & 41 & 31.1 & 0.79 \\
\hline NOCO-CO-09 & 37 & 46 & 17 & 7.8 & 0.45 \\
\hline NOCO-CO-10 & 5 & 95 & 0 & 3.5 & 0.02 \\
\hline NOCO-CO-11 & 61 & 9 & 30 & 8.1 & 1.49 \\
\hline NOCO-CO-12 & 49 & 31 & 21 & 20.3 & 0.03 \\
\hline NOCO-CO-13 & 0 & 14 & 86 & 23.1 & 0.04 \\
\hline NOCO-CO-14 & 0 & 47 & 53 & 44.9 & 0.10 \\
\hline NOCO-CO-15 & 0 & 83 & 17 & 0.6 & 0.01 \\
\hline NOCO-CO-16 & 0 & 100 & 0 & 0.4 & 0.02 \\
\hline NOCO-CO-17 & 90 & 10 & 0 & 17.3 & 0.02 \\
\hline NOCO-CO-18 & 2 & 63 & 35 & 9.5 & 0.11 \\
\hline NOCO-CO-19 & 99 & 1 & 0 & 2.1 & 0.46 \\
\hline NOCO-CO-20 & 1 & 80 & 19 & 1.7 & 0.18 \\
\hline NOCO-CO-21 & 80 & 1 & 19 & 2.0 & 1.17 \\
\hline NOCO-CO-22 & 88 & 11 & 1 & 5.8 & 0.05 \\
\hline NOCO-CO-23 & 44 & 22 & 34 & 24.9 & 0.37 \\
\hline NOCO-CO-24 & 1 & 99 & 0 & 12.4 & 0.11 \\
\hline NOCO-CO-25 & 9 & 50 & 41 & 7.3 & 0.63 \\
\hline NOCO-CO-26 & 0 & 82 & 18 & 1.3 & 0.33 \\
\hline NOCO-CO-27 & 93 & 5 & 2 & 1.1 & 0.04 \\
\hline NOCO-CO-28 & 0 & 100 & 0 & 1.4 & 0.19 \\
\hline NOCO-CO-29 & 95 & 5 & 0 & 3.4 & 0.10 \\
\hline NOCO-CO-30 & 1 & 58 & 41 & 4.8 & 0.19 \\
\hline
\end{tabular}

${ }^{1}$ Land-use data from Nakagaki and others (2007). Land-use percentages within 500-meter radius of each USGS-GAMA grid site (Johnson and Belitz, 2009). 
Table B3. Well and construction information and hydrologic conditions for U.S. Geological Survey (USGS) GAMA grid sites in the Northern Coast Ranges study unit, 2009, California GAMA Priority Basin Project.

[USGS-GAMA site identification numbers: NOCO-IN, Northern Coast Ranges study unit, Interior Basins study area; NOCO-CO, Northern Coast Ranges study unit, Coastal Basins study area. Abbreviations: GAMA, Groundwater Ambient Monitoring and Assessment Program; ft bls, feet below land surface; DOGGR, Division of Oil, Gas, and Geothermal Resources (California Department of Conservation); km, kilometer; LSD, land-surface datum; na, not available; DOM, domestic well; PSW, public-supply well (California Department of Health); IRR, irrigation well; IND, industrial well; INS, institutional well; SPR, spring site; STK, stock well; UNS, unused site; ${ }^{\circ} \mathrm{C}$, degrees Celsius]

\begin{tabular}{|c|c|c|c|c|c|c|c|c|c|c|}
\hline \multicolumn{3}{|c|}{ General information } & \multicolumn{4}{|c|}{ Construction information } & \multicolumn{4}{|c|}{ Hydrologic conditions } \\
\hline $\begin{array}{c}\text { USGS- } \\
\text { GAMA site } \\
\text { identification } \\
\text { number }\end{array}$ & $\begin{array}{c}\text { Altitude } \\
\text { of LSD } \\
\text { (ft above } \\
\text { NAVD 88) }\end{array}$ & $\begin{array}{l}\text { Site } \\
\text { type }\end{array}$ & $\begin{array}{l}\text { Well } \\
\text { depth } \\
\text { (ft bls) }\end{array}$ & $\begin{array}{c}\text { Depth to } \\
\text { top of } \\
\text { perforations } \\
\text { (ft bls) }\end{array}$ & $\begin{array}{c}\text { Depth to } \\
\text { bottom of } \\
\text { perforations } \\
\text { (ft bls) }\end{array}$ & $\begin{array}{l}\text { Length from top } \\
\text { of uppermost } \\
\text { perforated interval } \\
\text { to bottom of well } \\
\text { (ft bls) }\end{array}$ & $\begin{array}{l}\text { Aridity } \\
\text { index }^{2}\end{array}$ & $\begin{array}{l}\text { Field water } \\
\text { temperature } \\
\left({ }^{\circ} \mathrm{C}\right)\end{array}$ & $\begin{array}{l}\text { Distance to nearest } \\
\text { hot spring listed in } \\
\text { the USGS Mineral } \\
\text { Resources } \\
\text { Data System } \\
\text { (km) }\end{array}$ & $\begin{array}{l}\text { Distance to } \\
\text { nearest geothermal } \\
\text { well listed in the } \\
\text { DOGGR database } \\
\text { (km) }\end{array}$ \\
\hline \multicolumn{11}{|c|}{ Interior Basins study area } \\
\hline NOCO-IN-01 & 748 & IRR & 165 & 79 & 157 & 78 & 0.85 & 20.0 & 12.3 & 36.8 \\
\hline NOCO-IN-02 & 363 & PSW & 120 & 60 & 120 & 60 & 0.88 & 17.5 & 12.8 & 27.8 \\
\hline NOCO-IN-03 & 1,673 & DOM & 58 & 33 & 58 & 25 & 1.71 & 12.5 & 4.9 & 85.3 \\
\hline NOCO-IN-04 & 1,385 & DOM & 55 & na & na & na & 1.16 & 14.0 & 19.8 & 54.4 \\
\hline NOCO-IN-05 & 1,633 & UNS & 60 & na & na & na & 1.73 & 16.0 & 1.3 & 88.9 \\
\hline NOCO-IN-06 & 1,342 & DOM & 136 & na & na & na & 0.97 & 15.0 & 24.4 & 89.6 \\
\hline NOCO-IN-07 & 523 & PSW & 40 & 23 & 38 & 15 & 0.83 & 14.5 & 12.0 & 15.3 \\
\hline NOCO-IN-08 & 483 & PSW & 40 & 25 & 40 & 15 & 0.82 & 14.0 & 18.6 & 9.2 \\
\hline NOCO-IN-09 & 713 & PSW & 400 & 148 & 385 & 237 & 0.84 & 20.0 & 9.8 & 33.9 \\
\hline NOCO-IN-10 & 553 & PSW & 101 & 35 & 94 & 59 & 0.80 & 16.0 & 8.4 & 19.9 \\
\hline NOCO-IN-11 & 958 & DOM & 100 & 60 & 100 & 40 & 0.92 & 18.0 & 15.2 & 38.5 \\
\hline NOCO-IN-12 & 558 & IRR & 215 & 40 & 215 & 175 & 0.82 & 19.0 & 10.2 & 17.0 \\
\hline NOCO-IN-13 & 599 & PSW & 36 & 15 & 36 & 21 & 0.82 & 16.0 & 3.0 & 25.1 \\
\hline NOCO-IN-14 & 658 & IRR & 135 & 75 & 135 & 60 & 0.81 & 18.5 & 4.9 & 20.8 \\
\hline NOCO-IN-15 & 1,856 & PSW & 300 & 80 & 220 & 140 & 1.07 & 15.5 & 4.2 & 47.5 \\
\hline NOCO-IN-16 & 1,845 & PSW & 152 & 39 & 152 & 113 & 1.03 & 15.0 & 4.0 & 48.5 \\
\hline NOCO-IN-17 & 1,368 & DOM & 75 & na & na & na & 0.78 & 18.5 & 18.3 & 14.6 \\
\hline NOCO-IN-18 & 1,360 & IRR & 170 & 50 & 160 & 110 & 0.65 & 19.0 & 30.6 & 1.6 \\
\hline NOCO-IN-19 & 823 & DOM & 80 & 21 & 80 & 59 & 0.88 & 18.5 & 14.2 & 37.7 \\
\hline NOCO-IN-20 & 1,470 & DOM & 75 & na & na & na & 0.75 & 23.0 & 27.7 & 0.82 \\
\hline
\end{tabular}


Table B3. Well and construction information and hydrologic conditions for U.S. Geological Survey (USGS) GAMA grid sites in the Northern Coast Ranges study unit, 2009, California GAMA Priority Basin Project.-Continued

[USGS-GAMA site identification numbers: NOCO-IN, Northern Coast Ranges study unit, Interior Basins study area; NOCO-CO, Northern Coast Ranges study unit, Coastal Basins study area. Abbreviations: GAMA, Groundwater Ambient Monitoring and Assessment Program; ft bls, feet below land surface; DOGGR, Division of Oil, Gas, and Geothermal Resources (California Department of Conservation); km, kilometer; LSD, land-surface datum; na, not available; DOM, domestic well; PSW, public-supply well (California Department of Health); IRR, irrigation well; IND, industrial well; INS, institutional well; SPR, spring site; STK, stock well; UNS, unused site; ${ }^{\circ} \mathrm{C}$, degrees Celsius]

\begin{tabular}{|c|c|c|c|c|c|c|c|c|c|c|}
\hline \multicolumn{3}{|c|}{ General information } & \multicolumn{4}{|c|}{ Construction information } & \multicolumn{4}{|c|}{ Hydrologic conditions } \\
\hline $\begin{array}{c}\text { USGS- } \\
\text { GAMA site } \\
\text { identification } \\
\text { number }\end{array}$ & $\begin{array}{c}\begin{array}{c}\text { Altitude } \\
\text { of LSD }\end{array} \\
\text { (ft above } \\
\text { NAVD 88) }\end{array}$ & $\begin{array}{l}\text { Site } \\
\text { type }\end{array}$ & $\begin{array}{c}\text { Well } \\
\text { depth } \\
\text { (ft bls) }\end{array}$ & $\begin{array}{l}\text { Depth to } \\
\text { top of } \\
\text { perforations } \\
\text { (ft bls) }\end{array}$ & $\begin{array}{c}\text { Depth to } \\
\text { bottom of } \\
\text { perforations } \\
\text { (ft bls) }\end{array}$ & $\begin{array}{l}\text { Length from top } \\
\text { of uppermost } \\
\text { perforated interval } \\
\text { to bottom of well } \\
\text { (ft bls) }\end{array}$ & $\begin{array}{l}\text { Aridity } \\
\text { index }\end{array}$ & $\begin{array}{l}\text { Field water } \\
\text { temperature } \\
\left({ }^{\circ} \mathrm{C}\right)\end{array}$ & $\begin{array}{l}\text { Distance to nearest } \\
\text { hot spring listed in } \\
\text { the USGS Mineral } \\
\text { Resources } \\
\text { Data System } \\
(\mathrm{km})\end{array}$ & $\begin{array}{c}\text { Distance to } \\
\text { nearest geothermal } \\
\text { well listed in the } \\
\text { DOGGR database } \\
\text { (km) }\end{array}$ \\
\hline \multicolumn{11}{|c|}{ Interior Basins study area-Continued } \\
\hline NOCO-IN-21 & 361 & IRR & 52 & 40 & 48 & 8 & 0.64 & 18.5 & 30.9 & 1.4 \\
\hline NOCO-IN-22 & 801 & IRR & 180 & na & na & na & 0.80 & 25.0 & 0.61 & 1.0 \\
\hline NOCO-IN-23 & 1,399 & DOM & 142 & 40 & 142 & 102 & 0.98 & 15.0 & 23.7 & 93.7 \\
\hline NOCO-IN-24 & 1,380 & PSW & 116 & 70 & 115 & 45 & 0.61 & 18.5 & 28.5 & 2.3 \\
\hline NOCO-IN-25 & 1,072 & PSW & 283 & 56 & 217 & 161 & 0.83 & 19.0 & 16.0 & 0.37 \\
\hline NOCO-IN-26 & 1,154 & PSW & 126 & 30 & 114 & 84 & 0.48 & 18.0 & 5.3 & 42.5 \\
\hline NOCO-IN-27 & 1,776 & PSW & 155 & 40 & 115 & 75 & 0.71 & 18.0 & 22.0 & 6.0 \\
\hline NOCO-IN-28 & 1,345 & DOM & 41 & na & na & na & 0.98 & 15.5 & 24.3 & 87.8 \\
\hline \multicolumn{11}{|c|}{ Coastal Basins study area } \\
\hline NOCO-CO-01 & 71 & DOM & 25 & 16 & 18 & 2 & 0.93 & 13.0 & 36.8 & 88.0 \\
\hline NOCO-CO-02 & 48 & PSW & 55 & 35 & 55 & 20 & 0.86 & 13.5 & 20.2 & 51.1 \\
\hline NOCO-CO-03 & 38 & PSW & 380 & 280 & 370 & 90 & 1.19 & 11.0 & 111 & 221 \\
\hline NOCO-CO-04 & 243 & PSW & 325 & na & na & na & 1.28 & 12.5 & 109 & 212 \\
\hline NOCO-CO-05 & 126 & PSW & 15 & 10 & 10 & 0 & 0.99 & 12.0 & 42.3 & 83.9 \\
\hline NOCO-CO-06 & 95 & PSW & 37 & 20 & 37 & 17 & 1.01 & 12.0 & 37.2 & 75.8 \\
\hline NOCO-CO-07 & 124 & PSW & 130 & 10 & 130 & 120 & 1.54 & 11.5 & 102 & 260 \\
\hline NOCO-CO-08 & 33 & PSW & 215 & 150 & 210 & 60 & 1.29 & 14.5 & 98.6 & 233 \\
\hline NOCO-CO-09 & 5 & IND & 397 & 356 & 376 & 20 & na & 18.0 & 102 & 225 \\
\hline NOCO-CO-10 & 115 & IRR & 225 & 210 & 220 & 10 & 1.49 & 13.0 & 89.8 & 225 \\
\hline NOCO-CO-11 & 50 & PSW & 115 & 43 & 103 & 60 & 1.23 & 14.5 & 103 & 202 \\
\hline NOCO-CO-12 & 56 & DOM & 62 & na & na & na & 1.25 & 15.5 & 109 & 220 \\
\hline NOCO-CO-13 & 318 & PSW & 100 & 34 & 100 & 66 & 1.48 & 13.0 & 99.1 & 247 \\
\hline NOCO-CO-14 & 42 & INS & 32 & 20 & 32 & 12 & 1.73 & 13.0 & 135 & 328 \\
\hline NOCO-CO-15 & 27 & PSW & 85 & 30 & 85 & 55 & 2.15 & 10.5 & 113 & 302 \\
\hline
\end{tabular}


Table B3. Well and construction information and hydrologic conditions for U.S. Geological Survey (USGS) GAMA grid sites in the Northern Coast Ranges study unit, 2009, California GAMA Priority Basin Project.-Continued

[USGS-GAMA site identification numbers: NOCO-IN, Northern Coast Ranges study unit, Interior Basins study area; NOCO-CO, Northern Coast Ranges study unit, Coastal Basins study area. Abbreviations: GAMA, Groundwater Ambient Monitoring and Assessment Program; ft bls, feet below land surface; DOGGR, Division of Oil, Gas, and Geothermal Resources (California Department of Conservation); km, kilometer; LSD, land-surface datum; na, not available; DOM, domestic well; PSW, public-supply well (California Department of Health); IRR, irrigation well; IND, industrial well; INS, institutional well; SPR, spring site; STK, stock well; UNS, unused site; ${ }^{\circ} \mathrm{C}$, degrees Celsius]

\begin{tabular}{|c|c|c|c|c|c|c|c|c|c|c|}
\hline \multicolumn{3}{|c|}{ General information } & \multicolumn{4}{|c|}{ Construction information } & \multicolumn{4}{|c|}{ Hydrologic conditions } \\
\hline $\begin{array}{c}\text { USGS- } \\
\text { GAMA site } \\
\text { identification } \\
\text { number }\end{array}$ & $\begin{array}{c}\text { Altitude } \\
\text { of LSD } \\
\text { (ft above } \\
\text { NAVD 88) }\end{array}$ & $\begin{array}{l}\text { Site } \\
\text { type }\end{array}$ & $\begin{array}{c}\text { Well } \\
\text { depth } \\
\text { (ft bls) }\end{array}$ & $\begin{array}{l}\text { Depth to } \\
\text { top of } \\
\text { perforations } \\
\text { (ft bls) }\end{array}$ & $\begin{array}{c}\text { Depth to } \\
\text { bottom of } \\
\text { perforations } \\
\text { (ft bls) }\end{array}$ & $\begin{array}{l}\text { Length from top } \\
\text { of uppermost } \\
\text { perforated interval } \\
\text { to bottom of well } \\
\text { (ft bls) }\end{array}$ & $\begin{array}{l}\text { Aridity } \\
\text { index }^{2}\end{array}$ & $\begin{array}{l}\text { Field water } \\
\text { temperature } \\
\left({ }^{\circ} \mathrm{C}\right)\end{array}$ & $\begin{array}{l}\text { Distance to nearest } \\
\text { hot spring listed in } \\
\text { the USGS Mineral } \\
\text { Resources } \\
\text { Data System } \\
\text { (km) }\end{array}$ & $\begin{array}{c}\text { Distance to } \\
\text { nearest geotherma } \\
\text { well listed in the } \\
\text { DOGGR database } \\
(\mathbf{k m})\end{array}$ \\
\hline \multicolumn{11}{|c|}{ Coastal Basins study area-Continued } \\
\hline NOCO-CO-16 & 56 & PSW & 75 & 38 & 58 & 20 & 2.17 & 13.0 & 132 & 329 \\
\hline NOCO-CO-17 & 153 & PSW & 50 & 23 & 50 & 27 & 1.28 & 15.0 & 96.0 & 196 \\
\hline NOCO-CO-18 & 39 & PSW & 65 & 55 & 60 & 5 & 1.26 & 14.5 & 106 & 207 \\
\hline NOCO-CO-19 & 37 & DOM & 50 & na & na & na & 1.17 & 13.5 & 109 & 208 \\
\hline NOCO-CO-20 & 93 & SPR & at LSD & at LSD & at LSD & at LSD & 1.24 & 12.5 & 113 & 208 \\
\hline NOCO-CO-21 & 24 & PSW & 168 & 146 & 166 & 20 & 1.18 & 14.5 & 112 & 209 \\
\hline NOCO-CO-22 & 15 & IRR & 35 & na & na & na & 1.87 & 13.0 & 142 & 339 \\
\hline NOCO-CO-23 & 39 & PSW & 45 & 35 & 45 & 10 & 2.00 & 14.5 & 142 & 341 \\
\hline NOCO-CO-24 & 24 & STK & 15 & na & na & na & 1.70 & 12.5 & 139 & 332 \\
\hline NOCO-CO-25 & 13 & IND & 193 & 175 & 193 & 18 & 1.20 & 14.0 & 99.8 & 225 \\
\hline NOCO-CO-26 & 267 & PSW & 15 & 15 & 15 & 0 & 1.55 & 12.0 & 102 & 252 \\
\hline NOCO-CO-27 & 8 & DOM & 400 & na & na & na & 1.20 & 15.5 & 110 & 216 \\
\hline NOCO-CO-28 & 18 & DOM & 120 & na & na & na & 1.21 & 14.0 & 103 & 234 \\
\hline NOCO-CO-29 & 10 & IRR & 200 & na & na & na & 1.26 & 13.0 & 101 & 234 \\
\hline NOCO-CO-30 & 390 & PSW & 196 & 166 & 196 & 30 & 1.38 & 15.5 & 99.6 & 200 \\
\hline
\end{tabular}

${ }^{1}$ LSD is a datum plane that is approximately at land surface at each site. The altitude of the LSD is described in feet above the North American Vertical Datum of 1988.

${ }^{2}$ Aridity index is average annual precipitation (PRISM Group, Oregon State University, 2012) divided by average annual evapotranspiration (Flint and Flint, 2007). 
Table B4. Groundwater age classification and the associated data for U.S. Geological Survey (USGS) GAMA grid sites in the Northern Coast Ranges study unit, 2009, California GAMA Priority Basin Project.

[Groundwater age classification: Modern, groundwater recharged since 1952; Pre-modern, groundwater recharged before 1952; Mixed-age, groundwater recharged before and after 1952. Well depth classifications: Shallow, wells with depth above $70 \mathrm{ft}$ bls; Mixed-depth, wells with perforations beginning above $70 \mathrm{ft}$ bls and ending below $70 \mathrm{ft}$ bls; Deep, wells with perforations entirely below $70 \mathrm{ft}$ bls; Mixed-depth or Deep, wells with total well depth below $70 \mathrm{ft}$ bls and unknown perforation information. USGS-GAMA site identification numbers: NOCO-IN, Northern Coast Ranges study unit, Interior Basins study area; NOCO-CO, Northern Coast Ranges study unit, Coastal Basins study area. Abbreviations: $\mathrm{ft}$ bls, feet below land surface; ${ }^{14} \mathrm{C}$, carbon-14; TU, tritium units; nc, not collected; <, less than; LSD, land-surface datum]

\begin{tabular}{|c|c|c|c|c|c|}
\hline $\begin{array}{l}\text { USGS-GAMA site } \\
\text { identification number }\end{array}$ & $\begin{array}{l}\text { Tritium } \\
\text { (TU) }\end{array}$ & $\begin{array}{l}\text { Percent } \\
\text { modern } \\
\text { carbon }\end{array}$ & $\begin{array}{l}\text { Uncorrected } \\
{ }^{14} \mathrm{C} \text { age } \\
\text { (years) }\end{array}$ & $\begin{array}{l}\text { Groundwater age } \\
\text { classification }\end{array}$ & $\begin{array}{l}\text { Well depth } \\
\text { classifications }\end{array}$ \\
\hline NOCO-IN-01 & 0.09 & 40 & 7,260 & Pre-modern & Deep \\
\hline NOCO-IN-02 & 1.41 & 83 & 1,460 & Mixed-age & Mixed-depth \\
\hline NOCO-IN-03 & 1.31 & 106 & $<1,000$ & Modern & Shallow \\
\hline NOCO-IN-06 & -0.06 & 32 & 8,970 & Pre-modern & Mixed-depth or Deep \\
\hline NOCO-IN-07 & 2.82 & 105 & $<1,000$ & Modern & Shallow \\
\hline NOCO-IN-08 & 2.16 & 88 & $<1,000$ & Modern & Shallow \\
\hline NOCO-IN-09 & 0.09 & 22 & 12,030 & Pre-modern & Deep \\
\hline NOCO-IN-13 & 3.57 & 105 & $<1,000$ & Modern & Shallow \\
\hline NOCO-IN-14 & 0.81 & 57 & 4,520 & Mixed-age & Deep \\
\hline NOCO-IN-15 & 0.37 & 28 & 10,290 & Pre-modern & Deep \\
\hline NOCO-IN-16 & 1.78 & 79 & 1,850 & Mixed-age & Mixed-depth \\
\hline NOCO-IN-17 & 0.47 & 77 & 2,060 & Pre-modern & Mixed-depth or Deep \\
\hline NOCO-IN-18 & 1.31 & 78 & 1,900 & Mixed-age & Mixed-depth \\
\hline NOCO-IN-19 & 2.06 & 105 & $<1,000$ & Modern & Mixed-depth \\
\hline NOCO-IN-20 & 1.41 & 29 & ${ }^{19}, 930$ & Mixed-age & Mixed-depth or Deep \\
\hline NOCO-IN-21 & 1.81 & 106 & $<1,000$ & Modern & Shallow \\
\hline NOCO-IN-28 & 0.21 & 10 & 17,980 & Pre-modern & Shallow \\
\hline
\end{tabular}


Table B4. Groundwater age classification and the associated data for U.S. Geological Survey (USGS) GAMA grid sites in the Northern Coast Ranges study unit, 2009, California GAMA Priority Basin Project.-Continued

[Groundwater age classification: Modern, groundwater recharged since 1952; Pre-modern, groundwater recharged before 1952; Mixed-age, groundwater recharged before and after 1952. Well depth classifications: Shallow, wells with depth above $70 \mathrm{ft} \mathrm{bls;} \mathrm{Mixed-depth,} \mathrm{wells} \mathrm{with} \mathrm{perforations} \mathrm{beginning} \mathrm{above}$ $70 \mathrm{ft}$ bls and ending below $70 \mathrm{ft}$ bls; Deep, wells with perforations entirely below $70 \mathrm{ft}$ bls; Mixed-depth or Deep, wells with total well depth below $70 \mathrm{ft}$ bls and unknown perforation information. USGS-GAMA site identification numbers: NOCO-IN, Northern Coast Ranges study unit, Interior Basins study area; NOCO-CO, Northern Coast Ranges study unit, Coastal Basins study area. Abbreviations: $\mathrm{ft}$ bls, feet below land surface; ${ }^{14} \mathrm{C}$, carbon-14; TU, tritium units; nc, not collected; <, less than; LSD, land-surface datum]

\begin{tabular}{|c|c|c|c|c|c|}
\hline $\begin{array}{l}\text { USGS-GAMA site } \\
\text { identification number }\end{array}$ & $\begin{array}{l}\text { Tritium } \\
\text { (TU) }\end{array}$ & $\begin{array}{c}\text { Percent } \\
\text { modern } \\
\text { carbon }\end{array}$ & $\begin{array}{l}\text { Uncorrected } \\
{ }^{14} \mathrm{C} \text { age } \\
\text { (years) }\end{array}$ & $\begin{array}{l}\text { Groundwater age } \\
\text { classification }\end{array}$ & $\begin{array}{l}\text { Well depth } \\
\text { classifications }\end{array}$ \\
\hline \multicolumn{6}{|c|}{ Coastal Basins study area } \\
\hline NOCO-CO-01 & 1.00 & 57 & 4,410 & Mixed-age & Shallow \\
\hline NOCO-CO-02 & 1.50 & 107 & $<1,000$ & Modern & Shallow \\
\hline NOCO-CO-03 & 0.09 & 75 & 2,270 & Pre-modern & Deep \\
\hline NOCO-CO-06 & 2.25 & 92 & $<1,000$ & Modern & Shallow \\
\hline NOCO-CO-07 & 3.91 & 103 & $<1,000$ & Modern & Mixed-depth \\
\hline NOCO-CO-08 & 0.68 & 70 & 2,760 & Mixed-age & Deep \\
\hline NOCO-CO-09 & -0.03 & 9 & 19,060 & Pre-modern & Deep \\
\hline NOCO-CO-13 & 1.72 & 90 & $<1,000$ & Modern & Mixed-depth \\
\hline NOCO-CO-14 & 1.47 & nc & $\mathrm{nc}$ & Modern or Mixed-age & Shallow \\
\hline NOCO-CO-15 & 1.88 & 101 & $<1,000$ & Modern & Mixed-depth \\
\hline NOCO-CO-16 & 2.31 & 104 & $<1,000$ & Modern & Mixed-depth \\
\hline NOCO-CO-17 & 2.38 & 93 & $<1,000$ & Modern & Shallow \\
\hline NOCO-CO-18 & 1.78 & 86 & 1,110 & Mixed-age & Shallow \\
\hline NOCO-CO-19 & 1.63 & 104 & $<1,000$ & Modern & Shallow \\
\hline NOCO-CO-20 & 1.66 & 67 & 3,210 & Mixed-age & at LSD \\
\hline NOCO-CO-21 & 0.75 & 58 & 4,280 & Mixed-age & Deep \\
\hline NOCO-CO-28 & -0.06 & 53 & ${ }^{1} 5,010$ & Pre-modern & Mixed-depth or Deep \\
\hline NOCO-CO-29 & 2.88 & 77 & 1,990 & Mixed-age & Mixed-depth or Deep \\
\hline NOCO-CO-30 & 3.22 & 60 & 4,100 & Mixed-age & Deep \\
\hline
\end{tabular}

${ }^{1}$ Sample oxidation-reduction state was anoxic (table B5), and stable carbon isotope ratio was greater than -10 per mil, suggesting that the carbon isotope composition of the sample may have been altered by methanogenesis. The uncorrected carbon-14 apparent age thus may be too old. 
Table B5. Oxidation-reduction classification based on McMahon and Chapelle (2008), dissolved oxygen concentration, and pH for U.S. Geological Survey (USGS) GAMA grid sites in the Northern Coast Ranges study unit, 2009, California GAMA Priority Basin Project.

[Oxidation-reduction classification: Mn-red, manganese-reducing; Fe-red, iron-reducing; MnFe-red, manganese- and iron-reducing; $\mathrm{NO}_{3} \mathrm{MnFe}-\mathrm{red}$, nitrate-, manganese-, and iron-reducing; $\mathrm{NO}_{3} \mathrm{Mn}$-red, nitrate- and manganese-reducing. USGS-GAMA site identification numbers: NOCO-IN, Northern Coast Ranges study unit, Interior Basins study area; NOCO-CO, Northern Coast Ranges study unit, Coastal Basins study area. Abbreviations: GAMA, Groundwater Ambient Monitoring and Assessment Program; mg/L, milligrams per liter; $<$, less than]

\begin{tabular}{cccl}
\hline $\begin{array}{c}\text { USGS- } \\
\text { GAMA site } \\
\text { identification } \\
\text { number }\end{array}$ & $\begin{array}{c}\text { Dissolved } \\
\text { oxygen } \\
\text { (mg/L) }\end{array}$ & $\begin{array}{c}\text { pH } \\
\text { (standard } \\
\text { units) }\end{array}$ & \multicolumn{1}{c}{$\begin{array}{c}\text { 0xidation-reduction } \\
\text { classification' }\end{array}$} \\
\hline \multicolumn{4}{c}{ Interior Basins study area } \\
\hline NOCO-IN-01 & 0.7 & 7.5 & Anoxic Mn-red \\
NOCO-IN-02 & 7.0 & 7.2 & Oxic \\
NOCO-IN-03 & 0.7 & 6.1 & Anoxic Fe-red \\
NOCO-IN-04 & 10.9 & 6.3 & Mixed (Oxic/Anoxic Fe-red) \\
NOCO-IN-05 & 0.3 & 6.7 & Anoxic MnFe-red \\
& & & \\
NOCO-IN-06 & 0.4 & 7.2 & Anoxic MnFe-red \\
NOCO-IN-07 & 1.3 & 6.0 & Oxic \\
NOCO-IN-08 & 5.5 & 6.6 & Oxic \\
NOCO-IN-09 & 0.1 & 7.5 & Anoxic MnFe-red \\
NOCO-IN-10 & 5.0 & 6.4 & Oxic \\
NOCO-IN-11 & 0.3 & 6.8 & Anoxic NO 3 MnFe-red \\
NOCO-IN-12 & 2.2 & 6.9 & Oxic \\
NOCO-IN-13 & 3.8 & 6.1 & Oxic \\
NOCO-IN-14 & $<0.2$ & 7.3 & Anoxic MnFe-red \\
NOCO-IN-15 & $<0.2$ & 7.1 & Anoxic suboxic \\
NOCO-IN-16 & 1.9 & 6.4 & Oxic \\
NOCO-IN-17 & 6.2 & 6.9 & Oxic \\
NOCO-IN-18 & 1.3 & 6.7 & Oxic \\
NOCO-IN-19 & 2.6 & 6.0 & Oxic \\
NOCO-IN-20 & 0.3 & 6.3 & Anoxic MnFe-red \\
NOCO-IN-26 & 4.8 & 6.7 & Oxic \\
NOCO-IN-27 & $<0.2$ & 6.0 & Anoxic MnFe-red \\
NOCO-IN-28 & $<0.2$ & 7.2 & Anoxic Mn-red \\
NOCO-IN-21 & $<0.2$ & 6.8 & Anoxic MnFe-red \\
NOCO-IN-23 & 1.9 & 7.2 & Oxic \\
NOCO-IN-24 & 3.8 & 7.3 & Oxic \\
NOCO-IN-25 & 0.7 & 7.5 & Anoxic Fe-red \\
& & &
\end{tabular}

\begin{tabular}{|c|c|c|c|}
\hline $\begin{array}{c}\text { USGS- } \\
\text { GAMA site } \\
\text { identification } \\
\text { number }\end{array}$ & $\begin{array}{c}\text { Dissolved } \\
\text { oxygen } \\
\text { (mg/L) }\end{array}$ & $\begin{array}{c}\text { pH } \\
\text { (standard } \\
\text { units) }\end{array}$ & $\begin{array}{l}\text { Oxidation-reduction } \\
\text { classification }{ }^{1}\end{array}$ \\
\hline \multicolumn{4}{|c|}{ Coastal Basins study area } \\
\hline NOCO-CO-01 & $<0.2$ & 7.2 & Anoxic MnFe-red \\
\hline NOCO-CO-02 & 11.8 & 6.5 & Oxic \\
\hline NOCO-CO-03 & 1.3 & 7.7 & Oxic \\
\hline NOCO-CO-04 & $<0.2$ & 7.5 & Anoxic MnFe-red \\
\hline NOCO-CO-05 & 5.2 & 5.6 & Oxic \\
\hline NOCO-CO-06 & 4.1 & 6.5 & Oxic \\
\hline NOCO-CO-07 & 10.4 & 6.5 & Oxic \\
\hline NOCO-CO-08 & $<0.2$ & 7.5 & Anoxic suboxic \\
\hline NOCO-CO-09 & $<0.2$ & 7.5 & Anoxic MnFe-red \\
\hline NOCO-CO-10 & 3.3 & 7.8 & Oxic \\
\hline NOCO-CO-11 & 1.3 & 6.7 & Oxic \\
\hline NOCO-CO-12 & 1.1 & 6.8 & Oxic \\
\hline NOCO-CO-13 & 7.1 & 6.3 & Oxic \\
\hline NOCO-CO-14 & 9.7 & 7.7 & Oxic \\
\hline NOCO-CO-15 & 6.9 & 6.4 & Oxic \\
\hline NOCO-CO-16 & 7.9 & 6.7 & Oxic \\
\hline NOCO-CO-17 & 3.1 & 6.5 & Oxic \\
\hline NOCO-CO-18 & 0.3 & 6.5 & Anoxic $\mathrm{NO}_{3} \mathrm{MnFe}$-red \\
\hline NOCO-CO-19 & 0.2 & 6.6 & Anoxic $\mathrm{NO}_{3} \mathrm{Mn}$-red \\
\hline NOCO-CO-20 & 6.1 & 7.5 & Oxic \\
\hline NOCO-CO-21 & 0.4 & 7.0 & Anoxic $\mathrm{NO}_{3} \mathrm{MnFe}$-red \\
\hline NOCO-CO-22 & 7.5 & 6.7 & Oxic \\
\hline NOCO-CO-23 & 6.3 & 6.2 & Oxic \\
\hline NOCO-CO-24 & 0.8 & 6.8 & Anoxic MnFe-red \\
\hline NOCO-CO-25 & 0.3 & 6.7 & Anoxic Mn-red \\
\hline NOCO-CO-26 & 4.2 & 5.5 & Oxic \\
\hline NOCO-CO-27 & 0.2 & 6.8 & Anoxic MnFe-red \\
\hline NOCO-CO-28 & 0.4 & 7.2 & Anoxic MnFe-red \\
\hline NOCO-CO-29 & 0.4 & 7.3 & Anoxic $\mathrm{NO}_{3} \mathrm{Mn}$-red \\
\hline NOCO-CO-30 & 4.6 & 7.1 & Oxic \\
\hline
\end{tabular}

${ }^{1}$ Data from Mathany and others (2011) were used for the classification, in addition to the dissolved oxygen and $\mathrm{pH}$ data presented in this table. 


\section{Appendix C. Calculation of Aquifer-Scale Proportions}

Table C1. Aquifer-scale proportions calculated for the Interior Basins study area, using grid-based and spatially weighted methods for those constituents that met criteria for additional evaluation in the status assessment, Northern Coast Ranges study unit, 2009, California GAMA Priority Basin Project.

[Relative-concentration categories: high, concentration greater than water-quality benchmark; moderate, concentration is less than the benchmark and is greater than or equal to 0.1 of the benchmark (for organic and special-interest constituents) or 0.5 of the benchmark (for inorganic constituents); low, concentration less than 0.1 of benchmark (for organic constituents and special-interest constituents) or 0.5 of the benchmark (for inorganic constituents). Abbreviations: Groundwater Ambient Monitoring and Assessment Program; CDPH, California Department of Public Health; TDS, total dissolved solids; MTBE, methyl tert-butyl ether; $\mu \mathrm{g} / \mathrm{L}$, micrograms per liter]

\begin{tabular}{|c|c|c|c|c|c|c|c|c|c|c|c|}
\hline \multirow[t]{2}{*}{ Constituent } & \multicolumn{3}{|c|}{$\begin{array}{l}\text { Raw detection frequency, } \\
\text { in percent }{ }^{1}\end{array}$} & \multicolumn{3}{|c|}{$\begin{array}{l}\text { Spatially weighted } \\
\text { aquifer-scale proportion, } \\
\text { in percent }{ }^{1}\end{array}$} & \multicolumn{3}{|c|}{$\begin{array}{l}\text { Grid-based aquifer-scale proportion, } \\
\text { in percent }\end{array}$} & \multicolumn{2}{|c|}{$\begin{array}{l}90 \text { percent confidence } \\
\text { interval for grid-based } \\
\text { high proportion, } \\
\text { in percent }^{2}\end{array}$} \\
\hline & $\begin{array}{l}\text { Number } \\
\text { of sites }\end{array}$ & Moderate & High & $\begin{array}{l}\text { Number } \\
\text { of cells }\end{array}$ & $\begin{array}{l}\text { Moderate } \\
\text { aquifer } \\
\text { proportion }\end{array}$ & $\begin{array}{c}\text { High } \\
\text { aquifer } \\
\text { proportion }\end{array}$ & $\begin{array}{l}\text { Number } \\
\text { of sites }\end{array}$ & $\begin{array}{l}\text { Moderate } \\
\text { aquifer } \\
\text { proportion }\end{array}$ & $\begin{array}{c}\text { High } \\
\text { aquifer } \\
\text { proportion }\end{array}$ & $\begin{array}{l}\text { Lower } \\
\text { limit }\end{array}$ & $\begin{array}{l}\text { Upper } \\
\text { limit }\end{array}$ \\
\hline \multicolumn{12}{|c|}{ Inorganic constituents with health-based benchmarks } \\
\hline \multicolumn{12}{|l|}{ Trace Elements } \\
\hline Arsenic & 71 & 2.8 & 4.2 & 28 & 5.4 & 7.1 & 28 & 7.1 & 7.1 & 2.1 & 18.4 \\
\hline Barium & 71 & 0 & 1.4 & 28 & 0 & 3.6 & 28 & 0 & 3.6 & 0.6 & 13.1 \\
\hline Boron $^{3}$ & 28 & 7.1 & 17.9 & 28 & 7.1 & 17.9 & 28 & 7.1 & 17.9 & 8.5 & 31.9 \\
\hline Nickel & 71 & 0 & 0 & 28 & 0 & 0 & 28 & 0 & 0 & 0 & 6.6 \\
\hline \multicolumn{12}{|l|}{ Nutrients } \\
\hline Nitrate & 92 & 0 & 0 & 28 & 0 & 0 & 28 & 0 & 0 & 0 & 6.6 \\
\hline \multicolumn{12}{|c|}{ Inorganic constituents with aesthetic-based benchmarks } \\
\hline Iron & 60 & 8.3 & 26.7 & 28 & 12.2 & 27.7 & 28 & 10.7 & 25.0 & 13.7 & 39.9 \\
\hline Manganese & 62 & 3.2 & 37.1 & 28 & 7.1 & 46.1 & 28 & 7.1 & 42.9 & 28.5 & 58.3 \\
\hline TDS & 58 & 8.6 & 0 & 28 & 13.7 & 0 & 28 & 14.3 & 0 & 0 & 6.6 \\
\hline \multicolumn{12}{|c|}{ Organic constituents with health-based benchmarks } \\
\hline \multicolumn{12}{|l|}{ Volatile organic compounds } \\
\hline Chloroform (Trichloromethane) & 53 & 1.9 & 0 & 28 & 2.3 & 0 & 28 & 3.7 & 0 & 0 & 6.6 \\
\hline Vinyl chloride (Chloroethene) & 52 & 1.9 & 0 & 28 & 3.6 & 0 & 28 & 3.6 & 0 & 0 & 6.6 \\
\hline $\mathrm{MTBE}^{4}$ & 67 & 0 & 1.5 & 28 & 0 & 0.5 & 28 & 0 & 0 & 0 & 6.6 \\
\hline \multicolumn{12}{|l|}{ Pesticides and pesticide degradates } \\
\hline Simazine & 70 & 0 & 0 & 28 & 0 & 0 & 28 & 0 & 0 & 0 & 6.6 \\
\hline \multicolumn{12}{|c|}{ Special-interest constituent with health-based benchmark } \\
\hline Perchlorate & 78 & 0 & 0 & 28 & 0 & 0 & 28 & 0 & 0 & 0 & 6.6 \\
\hline
\end{tabular}


Table C2. Aquifer-scale proportions calculated for the Coastal Basins study area, using grid-based and spatially weighted methods for those constituents that met criteria for additional evaluation in the status assessment, Northern Coast Ranges study unit, 2009, California GAMA Priority Basin Project.

[Relative-concentration categories: high, concentration greater than water-quality benchmark; moderate, concentration is less than the benchmark and is greater than or equal to 0.1 of the benchmark (for organic and special-interest constituents) or 0.5 of the benchmark (for inorganic constituents); low, concentration less than 0.1 of benchmark (for organic constituents and special-interest constituents) or 0.5 of the benchmark (for inorganic constituents). Abbreviations: GAMA, Groundwater Ambient Monitoring and Assessment Program; CDPH, California Department of Public Health; \%, percent; TDS, total dissolved solids; MTBE, methyl tert-butyl ether]

\begin{tabular}{|c|c|c|c|c|c|c|c|c|c|c|c|}
\hline \multirow[t]{2}{*}{ Constituent } & \multicolumn{3}{|c|}{$\begin{array}{l}\text { Raw detection frequency, } \\
\text { in percent }{ }^{1}\end{array}$} & \multicolumn{3}{|c|}{$\begin{array}{l}\text { Spatially weighted } \\
\text { aquifer-scale proportion, } \\
\text { in percent }{ }^{1}\end{array}$} & \multicolumn{3}{|c|}{$\begin{array}{l}\text { Grid-based } \\
\text { aquifer-scale proportion, } \\
\text { in percent }\end{array}$} & \multicolumn{2}{|c|}{$\begin{array}{l}90 \text { percent confidence } \\
\text { interval for grid-based } \\
\text { high proportion, } \\
\text { in percent }{ }^{2}\end{array}$} \\
\hline & $\begin{array}{l}\text { Number } \\
\text { of sites }\end{array}$ & Moderate & High & $\begin{array}{l}\text { Number } \\
\text { of cells }\end{array}$ & $\begin{array}{l}\text { Moderate } \\
\text { aquifer } \\
\text { proportion }\end{array}$ & $\begin{array}{l}\text { High aquifer } \\
\text { proportion }\end{array}$ & $\begin{array}{l}\text { Number } \\
\text { of sites }\end{array}$ & $\begin{array}{l}\text { Moderate } \\
\text { aquifer } \\
\text { proportion }\end{array}$ & $\begin{array}{l}\text { High aquifer } \\
\text { proportion }\end{array}$ & $\begin{array}{l}\text { Lower } \\
\text { limit }\end{array}$ & $\begin{array}{l}\text { Upper } \\
\text { limit }\end{array}$ \\
\hline \multicolumn{12}{|c|}{ Inorganic constituents with health-based benchmarks } \\
\hline \multicolumn{12}{|l|}{ Trace Elements } \\
\hline Arsenic & 59 & 3.4 & 1.7 & 30 & 6.7 & 0.2 & 30 & 6.7 & 0 & 0 & 6.2 \\
\hline Barium & 60 & 0 & 0 & 30 & 0 & 0 & 30 & 0 & 0 & 0 & 6.2 \\
\hline Boron $^{3}$ & 30 & 3.3 & 0 & 30 & 3.3 & 0 & 30 & 3.3 & 0 & 0 & 6.2 \\
\hline Nickel & 62 & 1.7 & 0 & 30 & 3.3 & 0 & 30 & 3.3 & 0 & 0 & 6.2 \\
\hline \multicolumn{12}{|l|}{ Nutrients } \\
\hline Nitrate & 128 & 3.1 & 0 & 30 & 2.7 & 0 & 29 & 6.9 & 0 & 0 & 6.2 \\
\hline \multicolumn{12}{|c|}{ Inorganic constituents with aesthetic-based benchmarks } \\
\hline Iron & 61 & 4.9 & 16.4 & 30 & 1.0 & 23.9 & 30 & 0 & 26.7 & 15.3 & 41.2 \\
\hline Manganese & 61 & 4.9 & 24.6 & 30 & 8.3 & 36.7 & 30 & 10.0 & 36.7 & 23.5 & 51.6 \\
\hline TDS & 60 & 1.7 & 0 & 30 & 0.6 & 0 & 30 & 0 & 0 & 0 & 6.2 \\
\hline \multicolumn{12}{|c|}{ Organic constituents with health-based benchmarks } \\
\hline \multicolumn{12}{|l|}{ Volatile organic compounds } \\
\hline Chloroform (Trichloromethane) & 65 & 1.5 & 0 & 30 & 0.8 & 0 & 30 & 0 & 0 & 0 & 6.2 \\
\hline Vinyl chloride (Chloroethene) & 63 & 0 & 0 & 30 & 0 & 0 & 30 & 0 & 0 & 0 & 6.2 \\
\hline MTBE & 67 & 0 & 0 & 30 & 0 & 0 & 30 & 0 & 0 & 0 & 6.2 \\
\hline \multicolumn{12}{|l|}{ Pesticides and pesticide degradates } \\
\hline Simazine & 53 & 0 & 0 & 30 & 0 & 0 & 30 & 0 & 0 & 0 & 6.2 \\
\hline \multicolumn{12}{|c|}{ Special-interest constituent with health-based benchmark } \\
\hline Perchlorate & 84 & 1.2 & 0 & 30 & 1.1 & 0 & 30 & 3.3 & 0 & 0 & 6.2 \\
\hline
\end{tabular}

${ }^{1}$ Based on most recent analyses for each CDPH site during June 1, 2006-June 1, 2009, combined with data from USGS-GAMA grid sites.

${ }^{2}$ Based on the Jeffrey's interval for the binomial distribution (Brown and others, 2001).

${ }^{3}$ Boron was not sampled by the CDPH during June 1, 2006-June 1, 2009. 


\section{Appendix D. Comparison of CDPH and GAMA Priority Basin Data}

CDPH and USGS-GAMA data were compared to assess the validity of combining data for inorganic constituents from these different sources. Concentrations of inorganic constituents (calcium, magnesium, sodium, alkalinity, chloride, sulfate, TDS, and nitrate), which generally are prevalent at concentrations substantially greater than reporting levels, were compared for each site by using data from both sources. The USGS and CDPH water-quality databases contained data for major ions, trace elements, TDS, or nitrate (as nitrogen) for 17 of 58 sites. Wilcoxon rank-sum tests of paired analyses for these eight constituents indicated no significant differences between USGS-GAMA and CDPH data for these constituents. Although differences between the paired datasets occurred for some sites (most notably nitrate, as nitrogen), most sample pairs plotted close to a 1:1 line (fig. D1). These direct comparisons indicated that the USGS-GAMA and CDPH inorganic data were not significantly different.

Major-ion data from USGS-GAMA grid sites were plotted on a trilinear diagram (Piper, 1944) along with all CDPH major-ion data to determine whether the groundwater types in the USGS-GAMA grid sites were similar to groundwater types observed historically in the study unit. Trilinear diagrams show the relative abundance of major cations and anions (on a charge equivalent basis) as a percentage of the total ion content of the water (fig. D2). Trilinear diagrams often are used to define groundwater type (Hem, 1989). All cation and anion data in the CDPH waterquality database with a cation and anion imbalance less than 10 percent were retrieved and plotted on the trilinear diagram for comparison with USGS-GAMA grid site data.

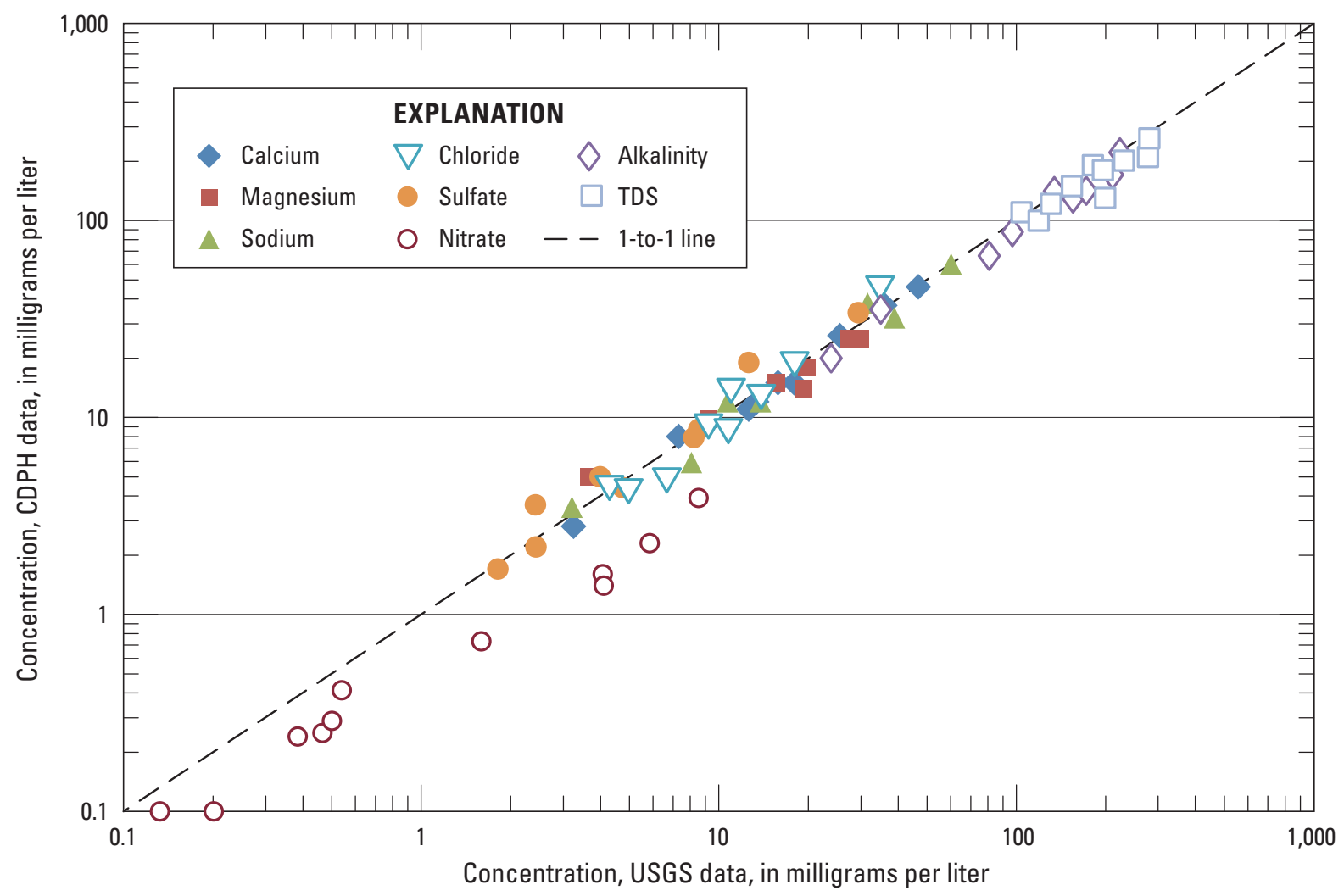

Figure D1. Paired inorganic constituent concentrations from sites sampled by the USGS-GAMA Program from June to November 2009 and from the CDPH database for the same sites during the period June 1, 2006-June 1, 2009, Northern Coast Ranges study unit, California GAMA Priority Basin Project. 


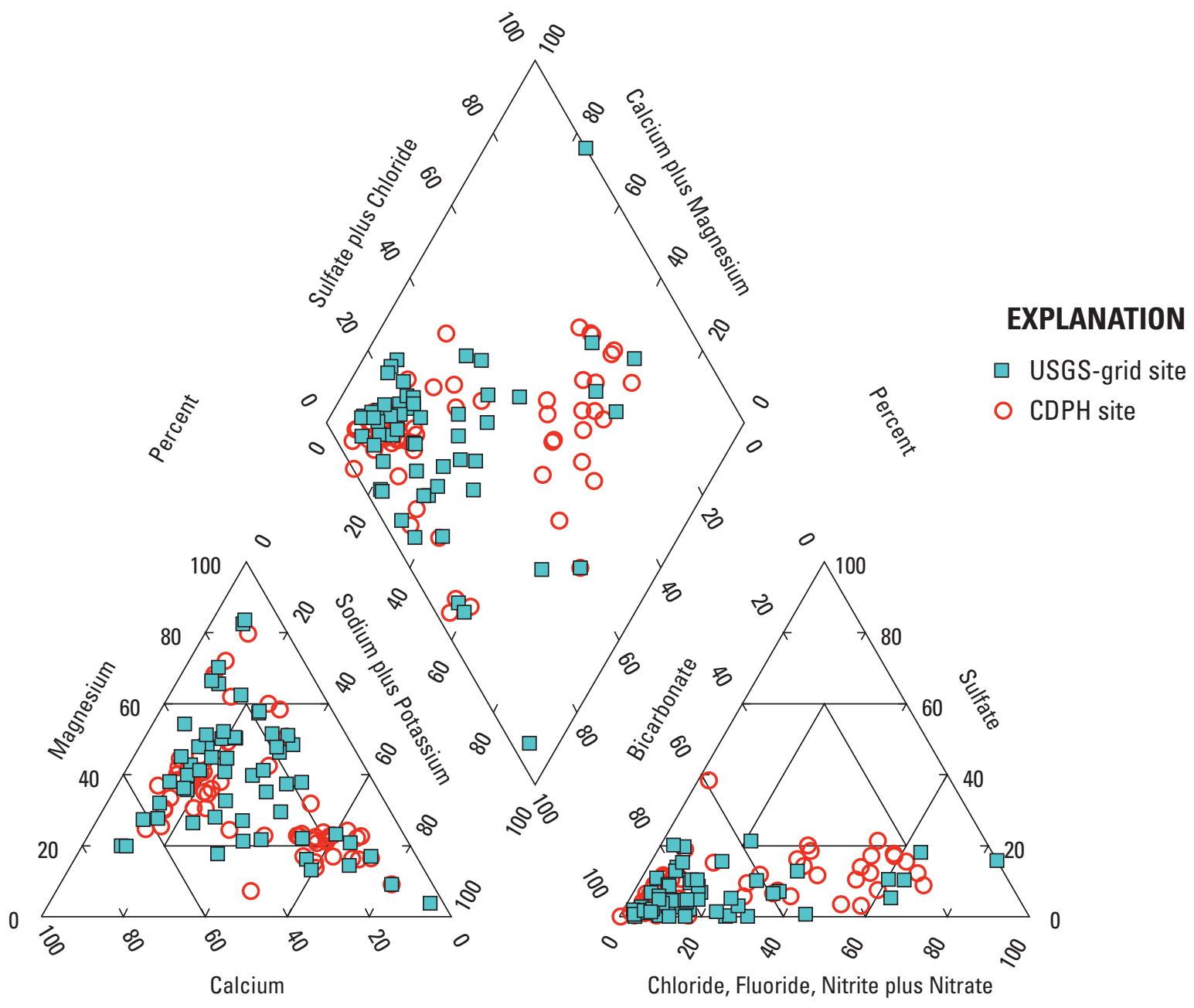

Percent

Figure D2. Selected inorganic data from USGS-GAMA grid sites and from all sites in the CDPH database that have a charge imbalance of less than 10 percent, Northern Coast Ranges study unit, 2009, California GAMA Priority Basin Project.

The ranges of water types for USGS-GAMA grid sites and other sites from the CDPH water-quality database were similar (fig. D2). In most water samples from the sites, no single cation accounted for more than 60 percent of the total cations, and bicarbonate accounted for more than 60 percent of the total anions. Waters in these sites are described as mixed cation-bicarbonate type waters. Some sites contained calcium/ magnesium-bicarbonate type waters, for which calcium plus magnesium and bicarbonate accounted for more than
60 percent of the cations and anions, respectively. Waters in a minority of sites were classified as sodium-chloride type waters, indicating that sodium and chloride accounted for more than 60 percent of the total cations and anions, respectively.

The determination that the range of relative abundance of major cations and anions in USGS-GAMA grid sites (58 sites) is similar to the range of those in all CDPH sites (60 sites) indicates that the grid sites represent the types of water present in the NOCO study unit. 


\section{Appendix E. Additional Water-Quality Data}

Table E1 presents the data generated at Lawrence Livermore National Laboratory (LLNL) for dissolved noble gases (argon, helium-4, krypton, neon, and xenon) and helium isotope ratios. These results were not completed in time for inclusion in the U.S. Geological Survey (USGS) Data Series Report for the Northern Coast Ranges (NOCO) study unit (U.S. Geological Survey Data Series 609, Mathany and others, 2011) and are included in this report for completeness.

Table E1. Results from the Lawrence Livermore National Laboratory (LLNL) analyses of dissolved noble gases and helium isotope ratios in samples from U.S. Geological Survey (USGS) GAMA grid sites collected for the Northern Coast Ranges study unit, 2009, California GAMA Priority Basin Project.

[The five-digit number in parentheses below the constituent name is the USGS parameter code used to uniquely identify a specific constituent or property. USGS-GAMA site identification numbers: NOCO-IN, Northern Coast Ranges study unit, Interior Basins study area; NOCO-CO, Northern Coast Ranges study unit, Coastal Basins study area. Measurement errors: Helium-3/Helium-4 ratios: 1\% error; helium-4 and argon concentrations: 2\% error; krypton concentrations: 3\% error; neon and xenon concentrations: $4 \%$ error. Abbreviations: $\mathrm{g}^{-1} \mathrm{H}_{2} \mathrm{O}$, pressure per gram of water; $\mathrm{R}$, helium-3/helium-4 ratio of the groundwater sample; Ra, helium-3/helium-4 ratio in the atmosphere; na, not available]

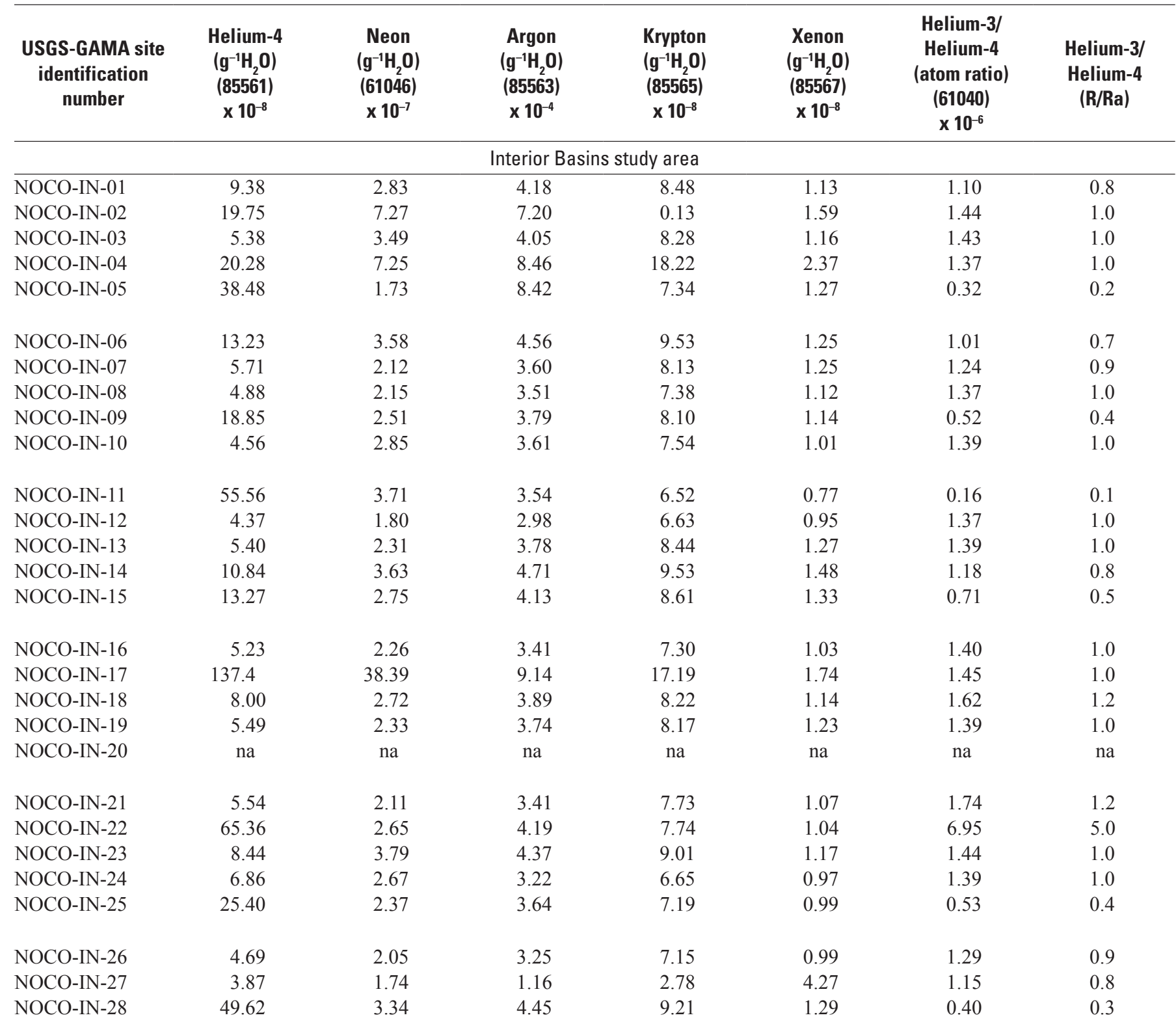


Table E1. Results from the Lawrence Livermore National Laboratory (LLNL) analyses of dissolved noble gases and helium isotope ratios in samples from U.S. Geological Survey (USGS) GAMA grid sites collected for the Northern Coast Ranges study unit, 2009, California GAMA Priority Basin Project.-Continued

[The five-digit number in parentheses below the constituent name is the USGS parameter code used to uniquely identify a specific constituent or property. USGS-GAMA site identification numbers: NOCO-IN, Northern Coast Ranges study unit, Interior Basins study area; NOCO-CO, Northern Coast Ranges study unit, Coastal Basins study area. Measurement errors: Helium-3/Helium-4 ratios: 1\% error; helium-4 and argon concentrations: $2 \%$ error; krypton concentrations: 3\% error; neon and xenon concentrations: $4 \%$ error. Abbreviations: $\mathrm{g}^{-1} \mathrm{H}_{2} \mathrm{O}$, pressure per gram of water; $\mathrm{R}$, helium-3/helium-4 ratio of the groundwater sample; Ra, helium-3/helium-4 ratio in the atmosphere; na, not available]

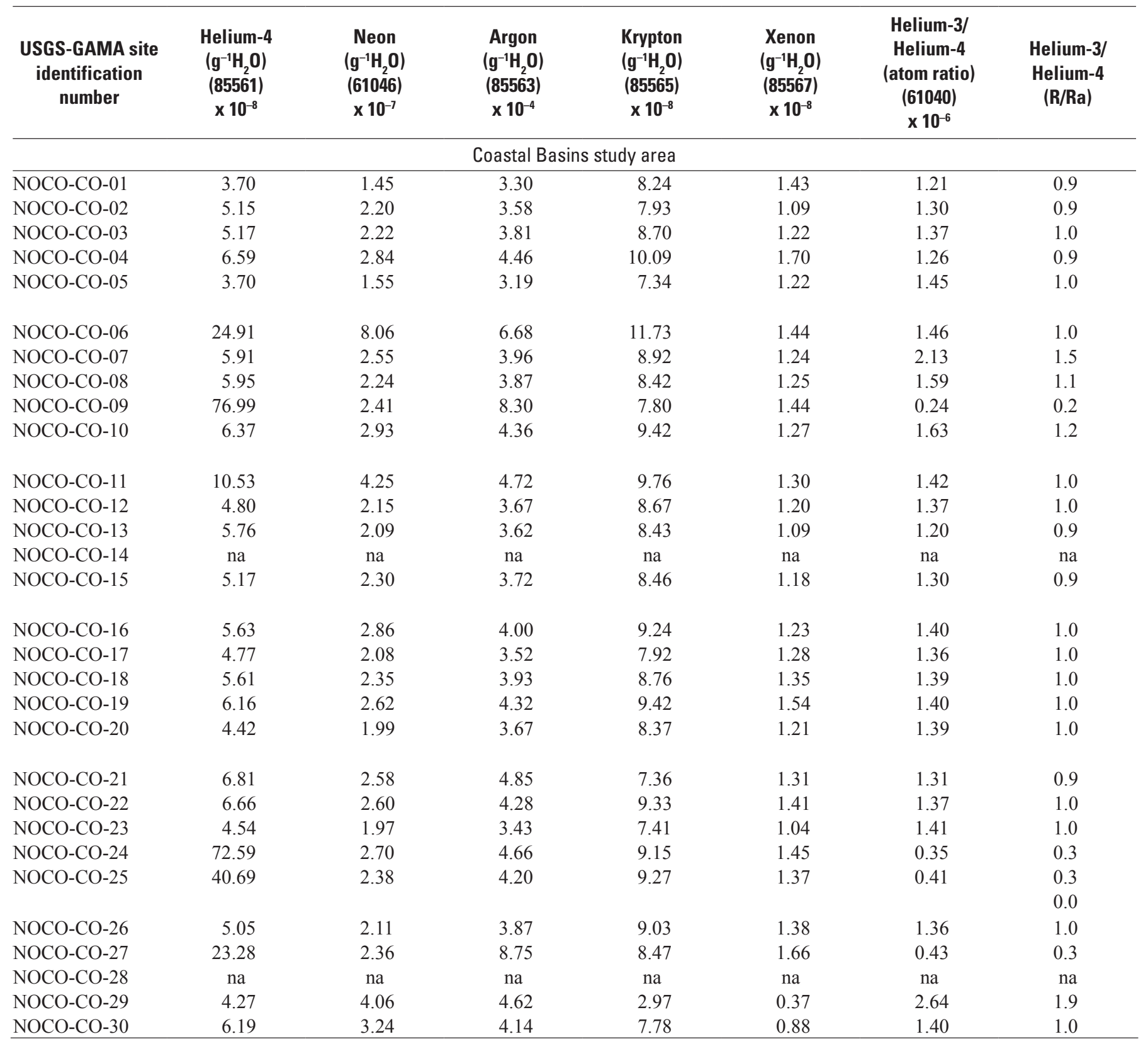


Publishing support provided by the U.S. Geological Survey Science

Publishing Network, Sacramento, Tacoma, and Raleigh Publishing Service Centers

For more information concerning the research in this report, contact the Director, California Water Science Center

U.S. Geological Survey

6000 J Street, Placer Hall

Sacramento, California 95819

http://ca.water.usgs.gov 


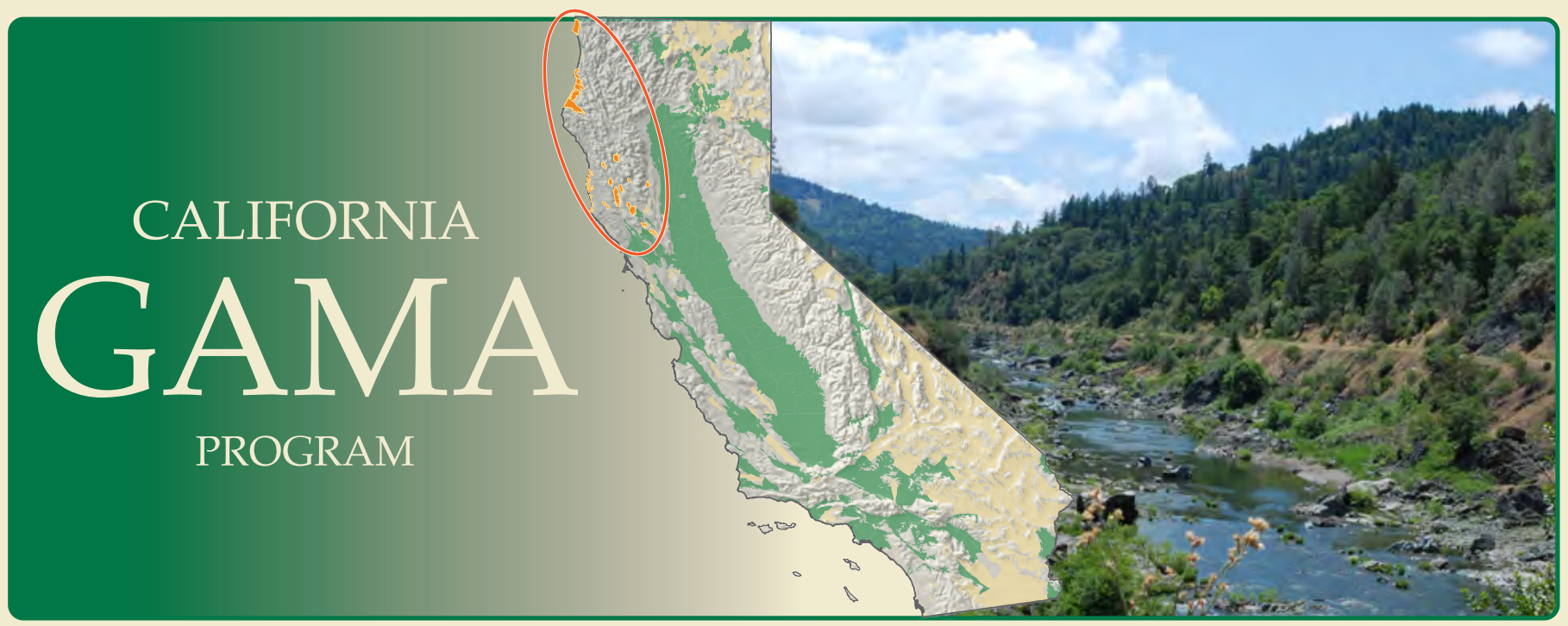

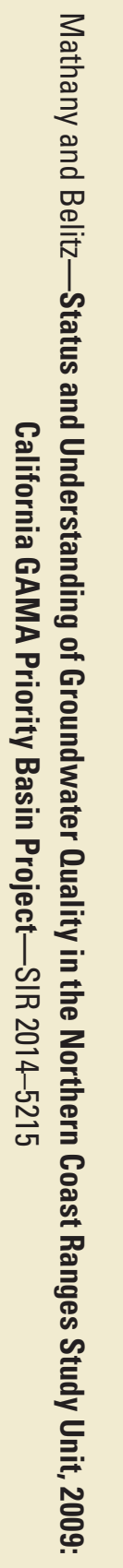

